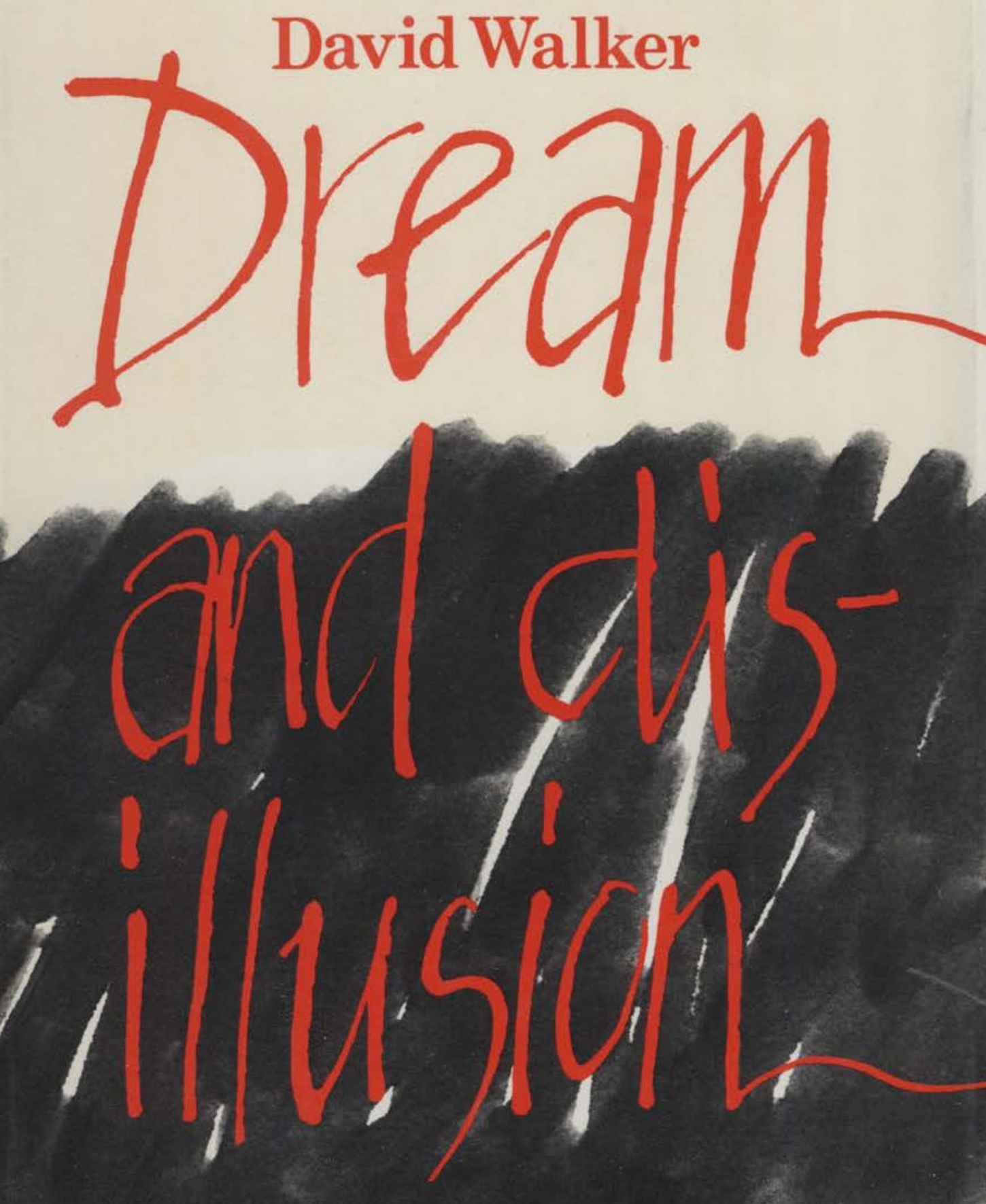

A search for Australian cultural Idenctiv? 
Works of literature are not created in isolation. They are formed by the interplay between personal and national identity, between the background of the writer and the ethos of his time.

This book explores, through the lives and works of four writers and their friends in Melbourne in the first forty years of this century Vance Palmer, Frank Wilmot, Louis Esson and Frederick Sinclaire - the struggle to identify what was unique and valuable in Australian life. Palmer and his associates sought to realise an Australian literary nationalism.

The book shows how the ferment of ideals and aspirations floundered inexorably into war, the violent social upheavals of conscription, and disillusion.

The author examines the ideals of his leading figures, and the ideas which informed their literary nationalism - identity with radical causes, an idealised bush life, robust masculinity; but he is also aware of the shortcomings of their

Australianism and suggests that these ideas were more inhibiting than their adherents believed.

Drawing on a rich array of private papers, articles, novels, and interviews to capture the flavour of this period, Dr Walker explores a vital area of Australian culture. The result is a fresh and persuasive account of the writers and their world. 
This book was published by ANU Press between 1965-1991. This republication is part of the digitisation project being carried out by Scholarly Information Services/Library and ANU Press.

This project aims to make past scholarly works published by The Australian National University available to a global audience under its open-access policy. 


\section{Dream and Disillusion}




\title{
Dream and Disillusion
}

A Search for Australian Cultural Identity

\author{
David Walker
}

Australian National University Press

Canberra $\leq 976$ 
First published in Australia 1976

Printed in Hong Kong for the Australian National University Press, Canberra

(C) David Walker 1976

This book is copyright. Apart from any fair dealing for the purpose of private study, research, criticism, or review, as permitted under the Copyright Act, no part may be reproduced by any process without written permission. Inquiries should be made to the publisher.

National Library of Australia

Cataloguing-in-Publication entry

Walker, David Robert

Dream and Disillusion

Index.

Bibliography.

ISBN 0708108253.

1. Australian literature - History and criticism.

I. Title.

A820.9002

North, South and Central America: Publisher's Marketing Group, Baker and Taylor Company, P.O. Box 305, Momence, Illinois.

Southeast Asia: Angus \& Robertson (S.E. Asia) Pty Ltd, Singapore.

Japan: United Publishers Services Ltd, Tokyo. 


\section{TO KAREN}




\section{Acknowledgments}

This book began as a Ph.D. thesis in the History Department of the Research School of Social Sciences at the Australian National University and was revised for publication during a Post-Doctoral Research Fellowship in the same department.

In the course of my research I received willing co-operation from the staffs of the National Library of Australia, particularly the staff of the manuscript room, the State Library of Victoria, the Mitchell Library, the Fisher Library, the Menzies Library of the Australian National University, and the Melbourne University Archives.

A number of people helped with information supplied in response to my requests. I owe a special debt to Helen Palmer, the late Guido Baracchi, Frederick Macartney, Hugh Esson, Winston Rhodes and Hartley Grattan, all of whom knew some or all of the major figures of my study and were kind enough to grant me interviews.

My supervisor, L. F. Fitzhardinge, helped in the preparation of the thesis as did Dr Robin Gollan who supervised my work during Mr Fitzhardinge's absence on study leave. More people than I can acknowledge have helped me with their comments. In particular, I would like to thank Professor J. A. La Nauze and Professor Oliver McDonagh and Drs F. B. Smith, Geoffrey Serle, Graeme Osborne and Peter Spearritt. Finally, I would like to thank Dr Leon Atkinson at the University of Adelaide for his interest in my project. His criticism and consideration have been keenly appreciated.

Many hands typed what were justly called 'rough drafts'. My thanks go to Beverly Gallina, Jan Hicks, Janice Aldridge, Lois Simms and Mandy Hewlett.

Overall, chief thanks go to my wife, Karen. She remained a firm ally but a sound critic from the beginning of this project.

Auckland, 1976

D.R.W. 


\section{Abbreviations}

A.I.F. Australian Imperial Force

A.J.A. Australian Journalists' Association

A.N.U. Australian National University

I.W.W. Industrial Workers of the World

M.L. Mitchell Library

M.L.C. Melbourne Literary Club

.M.U.M. Melbourne University Magazine

IN.L.A. National Library of Australia

'S.R.G. Students' Representative Council

'V.L.C. Victorian Labour College

'V.S.L. State Library of Victoria

'V.S.P. Victorian Socialist Party 


\section{Contents}

A Acknowledgments

vii

Abbreviations

ix

I Introduction

I

I. Bushed: Louis Esson in Melbourne and Paris, I904-I9I4 I I

2. Vance Palmer: The Beginnings of a Literary Socialist $\quad 3^{\mathrm{r}}$

3. Vance Palmer in London 44

4. Frank Wilmot in Pursuit of Poetry, 1900-1914 61

5. Frederick Sinclaire: Socialist and Dissident Minister of Religion, I908-19I5 71

6. War and the Emerging National Culture 89

7. Post-war Disillusionment $\quad$ II9

8. The Pioneer Players $\quad$ I 34

9. The Inter-war Years: National Consciousness Recedes $\quad \mathbf{1 4 8}$

IIo. Vance Palmer's Writings $\quad 168$

II 1 . Conclusions 194

$\begin{array}{ll}\text { AAppendix } & 213\end{array}$

Notes 219

Söelected Bibliography $\quad 245$

Infndex $\quad 265$ 


\section{Introduction}

This book is about four men and their friends all of whom wanted to estrablish a national culture in Australia. While they sometimes disagxeed over what this involved they nevertheless shared opinions on how the cultural life of the nation might be improved. Convinced that too much respect was paid to the often false teachings which supported the Empire, the Church and Commercialism, they looked forward to the day when the Australian people would be free to cultivate more attractive social ideals. As young men, they predicted a distinctive Australian literature and more democratic forms of society than existed in their own day. They supported minority causes often on the fringes of Bohemia and the radical left, made sacrifices for Art, dreamt of great social changes, expressed kinship with tbush workers with whom they had little in common and made frequent dismissive gestures of complaint at the mediocrity of Australian city dwellers from whom their reading public was drawn. In small domestic gatherings, cafés and meetings they discussed the nature of their society and its future as a European nation on the edge of Asia. The character of these meetings is now difficult to recapture, but private correspondence, essays in now defunct little magazines and in old newspapers, along with autobiographical writings and interviews with near contemporaries, give substance to the aims and antipathies of those who occupy the foreground of this book. It remains to be asked what their views of a national culture were, how did they arise, how did they change, and what were the strengths and failings of their beliefs. As we pursue these questions, it becomes evident that the task of determining the character of a new society and predicting its destiny was a problematical exercise characterised by false leads, mistaken hopes and unforeseen circumstances. This is not to say that there are no discoverable patterns of thinking about the character of Australian society and the functioning of the imaginative writer. There are. But the patterns are not as 'natural' 'inevitable' or selfevident as some critics appear to believe.

Vance Palmer (1885-1959), Louis Esson (1879-1943), Frank Wilmot (1881-1942) and Frederick Sinclaire (1881-1954) were men of the same generation. Melbourne was their key intellectual 


\section{Dream and Disillusion}

milieu. All participated in the city's cultural and intellectual life and Palmer, Esson and Wilmot married into Melbourne families. Wilmot lived in Melbourne continuously and Palmer, Esson and Sinclaire for long periods. Their associations were not those of a tight coterie, but they were nevertheless close. Palmer and Esson were introduced to each other in 1913 by the two women they were to marry, Nettie Higgins and Hilda Bull, both former class-mates at the Presbyterian Ladies' College and later companions at Melbourne University. ${ }^{1}$ Palmer and Esson collaborated in 1915 and 1916 on the Australian Writers' and Authors' Guild and when the Essons left Australia late in 1916 they began a regular correspondence with the Palmers. In the early r920s the Essons returned to Melbourne where the Palmers helped them to form the Pioneer Players, a repertory theatre group which produced Australian plays. In $194^{8}$ the Meanjin press published a collection of Esson's letters which Palmer had compiled and edited as a tribute to his friend's memory. ${ }^{2}$

Frank Wilmot ('Furnley Maurice') was well known to Palmer, Esson and Sinclaire. Wilmot, the son of a pioneer socialist, developed a close interest in socialism, although he never joined the Victorian Socialist Party. Wilmot played a key role in establishing the Melbourne Literary Club in 1916 and he printed and for a time edited the club magazine, Birth. ${ }^{3} \mathrm{He}$ was also connected with the Pioneer Players, as organiser and contributing dramatist and, in 1924, he printed Palmer's The Black Horse and Other Plays. Earlier he had printed Palmer's second book of poetry, The Camp. From 1924 Wilmot attended the monthly meetings of a literary club founded by Percival Serle. The first meeting discussed Nettie Palmer's Modern Australian Literature and the club continued until Wilmot's death. The Palmers, and the poet Bernard O'Dowd, were among those who attended club meetings. ${ }^{4}$ In 1942, Vance Palmer published a brief commemorative biography of Frank Wilmot.

Frederick Sinclaire arrived in Melbourne with his wife in $\mathbf{1 9 0 8}$ to become a minister at the Eastern Hill Unitarian Church. $\mathrm{He}$ moved in university circles where he met the essayist Waltier Murdoch and the academic Archibald Strong. He was also an early member of the Victorian Socialist Party; it was here that the probably first met Bernard O'Dowd and Louis Esson, both foundiation members of the Victorian Socialist Party. Sinclaire latier resigned from the Unitarian Church and formed his own ministry, 


\section{Introduction}

The Free Religious Fellowship. The Palmers never became members of Sinclaire's Fellowship, but they made a number of contributions to his magazine, Fellowship. When the Melbourne Literary Club was formed, the Palmers and Frederick Sinclaire were among its most active supporters and for a time Nettie edited the Club magazine. Palmer, Sinclaire and Wilmot were also members of the Y Club which was formed in 1918 as a discussion group for those with socialist inclinations. ${ }^{5}$

While Melbourne was a focal point for these associations and the projects they produced, it would be wrong to assume that they liked the city. In the I87os and I880s Melbourne's growth had been remarkable enough for it to earn the now improbable title, 'Marvellous Melbourne'. Visitors praised the city's achievements, while local businessmen developed some extravagant notions about how progressive antipodean life might become. R.E.N. Twopeny, an English spokesman for the prosperous classes, wrote in his Town Life in Australia that the visitor who wanted to see 'the fullest development of Australasian civilization, whether in commerce or education, in wealth or intellect, in manners or customs' had to see Melbourne, not Sydney. ${ }^{6}$ Twopeny admitted that Sydney Harbour was a splendid attraction, but in almost every other respect he preferred Melbourne. However, the disastrous land boom of 1889 to 1894 revealed that much of Melbourne's extravagant growth was built on fraud..$^{7}$ In these years many people lost ill-gotten fortunes, while others were forced to endure the hardships of depression in a society in which the state made no provision for the poor. In the aftermath of the boom years the Victorian Government attempted to set the colony in order, but the old optimism had been eroded, initial growth was slow and Melbourne began to lose ground to Sydney as the premier city of Australia. The population of Melbourne, which had reached half a million by 1892 , would not reach that level again until 1900 . In these years a number of men of talent, among them the artists Julian Ashton and Norman Lindsay and the poets Victor Daley and Hugh McCrae, left Melbourne for Sydney where the Bulletin boasted of the support it gave to creative talent in Australia. ${ }^{8}$

The society which emerged from the land boom was often a depressingly narrow one. By the early 1900 s the voice of respectability was, if anything, louder and more insistent among the leaders of society than it had been twenty years before. It was a discouraging atmosphere for aspiring young writers. Melbourne seemed a dreary 


\section{Dream and Disillusion}

prospect when compared, as it sometimes was, with the more exciting atmosphere of Paris. It is true that in her early twenties Nettie Higgins wrote a reverential poem about Melbourne, but she had experienced no other city. ${ }^{9}$ This admiring phase soon passed. Vance Palmer disliked Melbourne and probably always thought of himself more as a Queenslander than a Victorian. Frank Wilmot was in no position to compare Melbourne with other cities, but it is clear from his poetry that he had a number of bitter feelings about the character of city life. However, Louis Esson was the most explicit of them all about Melbourne's failings. He was never lost for waspish comments about the city and its inhabitants and was always ready to dart off to the country or entertain the possibilities of Sydney or Paris. For Esson, Melbourne was a 'wowser, bourgeois town'. ${ }^{10}$ This complaint was a terse summary of deeper, more persistent grievances at the righteous tone of Australian society. Wowsers were a familiar enough target during Esson's lifetime, but they were an eminently deserving one. Their exertions helped make Melbourne the last city in the Empire to open its Public Library, Gallery and Museum on Sundays. ${ }^{11}$ The breakthrough came in 1904 when Esson was already an art-conscious young man in his mid-twenties. It was around this time that a friend of Esson's, Hugh McKay, was so enraged by the Christian spirit of Melbourne that he composed a small, lovingly decorated hand-printed journal for private circulation titled: 'Too Much Jesus: A Journal of Revolt Against the Great Scaly Plague - Christianity', in which he announced:

I don't believe in Jesus Christ, I don't believe in Gawd:

I scorn the crawling parsons and the missionary horde. ${ }^{12}$

With no less vehemence Esson told readers of the Bulletin in I9ro that Australians were "cursed by Sabbatarianism in its crudest form, mistaking gloom and indigestion for religious feeling'. ${ }^{13}$ Two years later Vance Palmer confided to a friend that there were only two people he really despised. He declined to name one of them, but the other was the Rev. W.H. Fitchett who re-appears in Chapter 4 as one of Frederick Sinclaire's conservative critics. ${ }^{14}$ It is sufficient to point out here that Fitchett was a leading Methodist clergyman, an active sabbatarian and a prolific author of pot-boiling histories which sang the praises of the British Empire at its bloodiest.

Esson's criticism of the religious spirit of Melbourne was part of a broader argument about the conflicting ideals which faced 


\section{Introduction}

the Australian people. There were those who maintained that men needed to be protected from their own base natures and from the predatory ambitions of other nations. They argued that the lax conditions of a new land encouraged men to defy the rules which made for civilised and orderly living. Accordingly, the guardians of public morality had to encourage respect for tried values. There were liberal variations upon this theme: AngloAustralians might respect precedent, but they could also feel that there were opportunities in Australia to correct some of the entrenched abuses of the old world. This position allowed room for pride in Australia without negating respect for the British heritage. Although one of the most resilient strands of Australia's political culture, it was not one that the young Louis Esson was excited by. He had little time either for conservatives or Deakinite liberals, for he believed that they were both incapable of creating a race of men equal to the demands and possibilities of the Australian continent. Esson believed that such a race was possible in Australia if people would only set their minds to achieving it. While he warned that a want of faith in what men could become might well defeat these high aims and the 'true Australians' who held them, Esson was hopeful that the day would come when the truly Australian spirit would prevail.

Vance Palmer developed a similar view of the conflicting ideals at work within Australian society. In the formative years before World War I Palmer was attracted to guild socialism, the idea of community, craftsmanship and folk-culture and was anxious at the spread of a mass, urbanised industrial society which he thought would gradually destroy the spiritual integrity of modern man. Palmer believed that the destructive influences of this form of society would render Australians incapable of building a new nation, whereas his preferred community would enlarge man's humanity and quicken his creative powers. It followed that there were those whose beliefs would make Australia an unjust and mediocre society and others who, if given a chance, would build a distinctive nation. In addition, Palmer frequently contrasted the city unfavourably with the bush and the pedant with the creative artist, while he thought dainty femininity and gentility lesser achievements than rugged manliness and honesty. As we shall see, many of the values Palmer advocated were also central to the New Age, a journal Palmer came to know well in London before World War I. Indeed, many of Palmer's conceptions of 


\section{Dream and Disillusion}

how Australia should develop were shaped during this period when Shaw, Chesterton and Wells were dominant literary figures and when the question of how to democratise English society and liberate the creative energy of the people concerned some of the liveliest minds of the time. Palmer's thought was moulded by influences of this kind and with individual variations the same could be said for Esson, Wilmot and Sinclaire.

In the years before World War I the principal figures of this study were confident that the spirit of man would flower more brightly in their coming Australia, despite their apprehensions about the repressive mentality of the dominant culture. These hopes were natural enough in writers who wanted to attract adherents to their cause and for whom speculations about the future provided a surrogate for their inadequate present. The presidential address to the Australian Literature Society in I9o9 developed several of these themes. ${ }^{15}$ The speaker was the poet, Bernard O'Dowd, an inspiration to many of the young creative artists of pre-war Melbourne. O'Dowd spoke of a world which had been cut adrift from its old moorings. Scientific advances were redefining man's place in the world, the power of religion and the theologian were in decline, while the mass of the population showed signs of an obsessive interest in pleasure and material satisfaction. O'Dowd was disturbed by the feeble indulgences of those who persisted with fake theories of art for art's sake when the world required a poetry of purpose that would steer past threatening dangers to the millennium. 'Poetry Militant' was a call to action. O'Dowd attacked the futile poets who bobbed about ludicrously in the wake of European fashions, only to grow immobile when the colonial backwater again stagnated. He told them that their servile reverence for the past had stunted their imagination and blinded them to the creative duties which their new society laid upon them. He resented those whose niggardly view of the future allowed them to dismiss Australia as a dull, colonial society, for he believed that they condemned talented young Australians to servile boredom or fantasies of escape. O'Dowd's efforts to encapsulate the European past and find a prophetic language which would suggest the spacious possibilities of the future were designed to give greater scope to the creative imagination in Australia. It was part of O'Dowd's purpose to improve the morale of the Australian writer by placing him in the vanguard of democratic advance, not at the rear of the procession of civilised nations. 


\section{Introduction}

O'Dowd's revaluation of the Australian situation had some important implications. The new and sometimes oafish manners of a colonial society could now be more sympathetically regarded as a sign of the noble simplicity of a new nation. Moreover, there were a variety of commentators for whom simplicity did not merely indicate an inability to be complex, but a positive denial of the falsity and cruel inequality that intricate societies were thought to breed. In this view the recovery of a lost simplicity was a necessary condition for the growth of a morally aware community. A.R. Orage, editor of the $\mathcal{N} e w A g e$, once wrote: "To go back is to go forward ...', while it has been said of Bergson, whose writings were favourably regarded by Esson and Sinclaire, that he complained of life 'moving in the direction of ever greater luxury and ever greater complexity .... To become godlike, therefore, men must first return to a simple life'. ${ }^{16}$ In similar vein, Edward Carpenter, whom Sinclaire recommended as an antidote to the times in 1915, once announced: 'The fashionable, the intellectual, and the commercial classes' had each grown narrow, whereas 'that great class which lives in direct contact with Nature' seemed to Carpenter 'to be by far the least narrowed, to be by far the most human . . ${ }^{17}$ Convictions of this kind indicated that it was misguided to prefer English complexity to Australian simplicity for to do so lessened Australia's opportunity to inaugurate a new democratic age in which men would learn to breathe a freer air.

The notion that Australian man should retreat from the complex present in order to gain access to a fuller future implied a transitional period in which the truly Australian writer would see the spareness and lack of tradition in Australia as the setting for a new beginning. In this view the apparent emptiness of Australian civilisation did not deserve condescending criticism, but required minds original enough to conceive a new future. Accordingly, the Australian writer was required to renounce the past in order that he might be more receptive to the demands of the new order. This state of expectant emptiness was thought to differ from the supposedly narrow 'old world' in that it promised the growth of a new consciousness. Yet if assumptions of this kind proved false, there could be no new future, merely the unpalatable present made more intolerable by the dead-weight of defeated hopes. World War I hastened this outcome.

J.A. Passmore has warned against the temptation to draw too stark a contrast between the 'optimistic perfectibilism of the 


\section{Dream and Disillusion}

pre-1914 world' and post-war cynicism, particularly in the years since $1939 .{ }^{18}$ Even so, he found ample evidence of a darker strain of pessimism in much post-war thought. The post-war threat of a compromised and forbidding future had some contradictory effects in Australia. Some believed that remoteness from Europe enabled Australia to resist defeatism, extremist politics and cultural modernism. Ken Inglis has used the phrase Anzac utopianism for one aspect of this search for a harmonious community, since many of its advocates were returned servicemen. ${ }^{19}$ But post-war Australia was depressing for the principal figures of this study, who hoped that the future would bring Australia closer to their own notions of the good society. Their future had closed in with alarming speed. In Igog O'Dowd had spoken of the coming millennium. Five years later World War I had broken out and within twenty years depression and fascism were immediate realities. For men who were always uneasily conscious of the shallowness of their nation's past, it was a disturbing realisation that their anticipated new order was in jeopardy. It appeared that their society had grown meaner and narrower, a hollow mockery of departed hopes. To men of this persuasion, 'suburbia' became a symbol of the drab seediness of a society which seemed immune to change and, particularly in the 1930s, dangerously unaware of events in Europe. According to Vance Palmer, this was a decade of 'spiritual paralysis'. ${ }^{20}$ At this time the despondent note in Frank Wilmot's poetry grew more insistent, Sinclaire mocked hopes he had entertained around the turn of the century and Louis Esson virtually ceased to write. It was a measure of the times that while each of these men had been excited by William Morris's News From Nowhere as young men, the world they came to know as adults inspired an unprecedented growth of pessimistic visions of the future, among them Orwell's Nineteen Eighty-Four and Huxley's Brave New World. They came to maturity in a world which did not inspire optimism.

The complaint against 'suburbia' fitted into a tradition in which what was both genteel British and ugly in Australian life invariably managed to triumph over what was considered generous, indigenous and humane. 'Suburbia' joined the wowser spirit, the colonial mentality, imperial patriotism, respectability, the middle classes, commercialism, industrial society, cheap popular culture and a variety of other evils which had supposedly stifled the generous and innovative impulses in Australian society. Yet while Esson and 


\section{Introduction}

Palmer, for example, liked to remind their readers and each other of the hardships which the Australian writer faced, they also felt that there was something bourgeois and effete about those who explored their own uncertainties and troubled consciences, particularly in a supposedly new society, in which the writer's noblest task was to turn a mob into a people. They felt obliged to be positive in the face of hardship. They felt that many of their negative feelings about Australia, their doubts and periods of depression, were too personal; morbidly introspective and defeatist for a reading public who they believed were in need of a robust national literature. This outlook did not preclude stark encounters with a tough environment, but it did encourage a suspicion of a more intimate, subtly drawn, introspective literature. This is more true of Esson and Palmer than of Frank Wilmot, whose poetry grew sharper and more intense as he surrendered old hopes in the 1930s. But Esson and Palmer often felt obliged, as Australian writers, to deal with aspects of working-class or rural life about which they knew relatively little. This was consistent with their belief that Australian writers had a better understanding of ordinary life than their English counterparts, an assumption which could readily become self-satisfied.

The emphasis of this book is upon the years before the end of World War II. By this time Esson and Wilmot had died and Sinclaire, who had been in New Zealand for almost fifteen years, had become a distant though not forgotten figure. By the 1940s the Palmers were established critics and writers. From April 1937 to I94 I Vance Palmer broadcast a fortnightly review of films and the theatre to Melbourne audiences, while from $193^{8}$ to I957, and less regularly thereafter until his death in 1959, Palmer broadcast a fortnightly national book review called 'Current Books Worth Reading'. ${ }^{21}$ In the r 940 os Vance and Nettie Palmer also wrote regularly for the $A B C$ Weekly, a journal with an average weekly circulation in 1940 of around $50,000 .{ }^{22}$ This body of writings is not examined systematically in this book, although anyone wanting to do so should consult the bibliography which lists Palmer's ABC broadcasts from 194I to 1959. Palmer's National Portraits also reached a wide audience. The book has now sold almost 30,000 copies, while The Legend of the Nineties, first published in 1954 , has sold almost ${ }_{15}, 000 .^{23}$ During this period articles and lectures by the Palmers also reached small audiences in magazines like Meanjin Quarterly and Overland and in Commonwealth Literary 


\section{Dream and Disillusion}

Fund lectures delivered in several Australian capital cities and in Canberra. That they were able to reach such audiences was one realisation of their hopes for a national literature. What they said to them was largely influenced by patterns of thinking which went back to their formative years before and during World War I when they were in their twenties or early thirties.

This book does not claim to exhaust its subject. The issues it raises are broad and it covers aspects of our past where often quite basic research is still lacking. However, there are signs of change. Biographies, for example, are currently being written on Brian Fitzpatrick, Frederick Eggleston, Walter Murdoch and Katharine Susannah Pritchard. Any one of these works would have added something to our understanding of the cultural milieu in which the Palmers worked. Without them the cultural history of Australia in the first half of the twentieth century remains fragmentary and elusive. Yet despite such handicaps this book does claim to make an original examination of what constitutes an Australian national culture, a recurring theme in the history of the creative spirit in Australia. 


\section{Bushed: Louis Esson in Melbourne and Paris, I 904 -I 9 I 4 *}

In his two volume history of Australian Literature H.M. Green described Louis Esson as 'the founder of the Australian drama'. Other critics have described him in similar terms as 'the first Australian playwright to achieve literary distinction for dramas in an Australian setting and characterization'; as a playwright whose one-act plays 'evoke an atmosphere unique in the sense that it is fresh, individual, non-derivative Australian'; as a dramatist whose plays revealed 'a genuine attempt to express Australian life in dramatic terms'; and Leslie Rees in his study of Australian drama declared that Esson's 'crusade was real and significant and his contribution of first-rate plays, though small, is entirely valuable in our literary and dramatic history'. ${ }^{1}$ From these naming and classifying statements we learn that Esson was first in a particular respect, that this was related to his being 'Australian' and that his 'Australianness' is a quality of abiding interest, particularly to Australians. These judgments approve what Esson sought to do. They suggest that he was not only on the right path, but that there was a right path for the Australian writer to be on.

This retrospective view of Esson obscures his uncertainty about what it meant to be an artist with a particular obligation to 'national' themes. Indeed, Louis Esson's first literary and political contributions to the Bulletin in 1904, when he was in his mid-twenties, reveal a young man who idealised a world of crowded cafés, cheap red wine and animated conversations about art. He saw himself as a poet. $\mathrm{He}$ was proud of his individuality, contemptuous of 'mere

* A shorter and earlier version of this chapter was published in Meanjin Quarterly, No.4, 1972. I would like to thank Clem Christesen and Arthur Phillips for their astute comments on an early draft of this article. 


\section{Dream and Disillusion}

work', impatient with the working man, hostile to the middle class and dismissive of Lawson and the people he wrote about. He was a young man who associated art with refinement, cultivation and elegance, all qualities which he considered were beyond the grasp of the ordinary citizen. ${ }^{2}$ When critics later admired Esson's freshness, his individuality, his evocation of Australian scenes and characters, his non-derivative manner and his worthy crusade, they wrote of qualities which Esson acquired in the process of becoming an 'Australian' dramatist. It is important to stress this element of choice in Esson's literary career, for it is a mistake to suppose that he wrote of Australia and her people from the fullness of an untutored heart. As a young man Louis Esson conceived the idea of being a writer and in his subsequent career continued to make choices about what sort of writer he would be.

Throughout his literary career Esson maintained a generous conception of the artist's importance in human affairs. This needs to be accounted for in any explanation of how he became an 'Australian' dramatist, for Esson had to be reconciled to the treatment of Australian themes given that he once believed that Henry Lawson wrote of settings and people too trivial and sordid for the consideration of a real artist. Broadly, this reconciliation took two forms. In 1905 Louis Esson met J.M. Synge and W.B. Yeats, two figures of great stature in contemporary literature. They advised Esson that he had an Australian mission: 'to conquer the out-lying provinces and bring them within the kingdom of Art' ${ }^{3}$ This advice lifted Australian themes to a new plane of importance in Esson's thinking. Another key influence, particularly in the years from 1905 to the outbreak of the World War I, was Bernard O'Dowd's grand visions of the creative artist leading men from darkness to light in a new Australia. Such schemes satisfied an appetite for importance in Louis Esson's makeup and helped persuade him that Australian themes could be challenging enough to engage his interest.

It is doubtful, however, if Esson was ever convinced that Australian themes were capable of evoking great literature. Although he took some comfort from the advice of Synge and Yeats and the prophecies of Bernard O'Dowd, he felt that a taint of mediocrity afflicted Australia. Overall, Esson's relationship to Australia was troubled, complex and given to both rhetorical overstatement of the Australian promise and bitter denunciation of Australia's mediocrity. Interludes of enthusiasm for a national literature and outbursts of 


\section{Bushed}

creative energy were balanced by long periods of depression and illness in which he worked fitfully and without conviction. In tributes to Esson's memory after his death in 1942, close friends recalled that in familiar surroundings he was a witty and engaging conversationalist, but they were not blind to those more troubled and divisive sides of his nature which helped to diminish his output and achievements as a creative writer. Vance Palmer wrote of him: 'Very few writers have been lucky enough to express themselves completely in their work. Louis, alas, was not one of them. There were too many barriers, outside himself and within.'4

While no account of Esson could resolve the relative importance of 'nature and nurture' in shaping his literary career, aspects of his unusual upbringing need to be noted. Louis Esson was born in Edinburgh in 1879. His full name, Thomas Louis Buvelot Esson, indicates existing ties of association on his mother's side of the family with Australia and her interest in art. (Louis Buvelot was a painter of European origin who spent some twenty years in Australia.) When he was four, Louis was brought to Melbourne by his mother, following his father's death six months earlier. Once in Melbourne his mother soon re-married and Louis was passed over to the guardianship of two maiden aunts and two bachelor uncles. One uncle was the artist John Ford Paterson, the other uncle, James Paterson, ran a printing and decorating business which maintained the group and allowed John Ford Paterson to devote himself to painting. At Melbourne University, Esson studied English and French, but he did not complete his degree. While this family background favoured Louis Esson's creative aspirations and familiarised him with aspects of the artist's life, his upbringing did not prepare him for the harsher realities of earning a living by his pen in the wider world. 5

Whatever Esson's frailties, it is necessary to evaluate the choices he made about the sort of writer he was to become. How wisely did he make these choices and how well did 'national themes' suit his abilities and enrich his imagination? Moreover, how did the young poet who considered himself above the philistine herd become a dramatist who strove to establish a 'folk-theatre' in Australia?

In 1923 Louis Esson looked back almost twenty years to the enthusiasms and artistic dilemmas which had stirred him as a young man on his first stay in Paris in 1904 and 1905 . He recalled the vividness of Paris and the greyness of Australia: 


\section{Dream and Disillusion}

I loved Paris - the cafés, the cabarets, the theatres and restaurants the violent arguments, the brilliant scenes, the late walks down the hill from Montmartre. Australia appeared to be a far-off land, sometimes alluring, but rather vague and empty. How was it possible to make any literature about people who knew nothing except how to drive cattle and shear sheep? Lawson was writing short stories about them, but I didn't think much of Lawson then. He hadn't enough style for my taste. Art was something more refined than that, an elegant, fantastic thing, like a Conder fan, or an Oscar Wilde play about cultivated people who spoke in epigrams . . . .6

In 1939 Esson again evoked the years around 1904 when he pictured Australia as a country in which 'no one was interested in art or literature - it was crude, materialistic, Philistine . . . ?

When the young Louis Esson of I904 looked back to the I8gos it was not Henry Lawson he admired, but Oscar Wilde who conjured up an imagined world of aristocratic ease, spaciousness, cucumber sandwiches and unflappable self-possession. Esson considered that no one with delicate sensibilities would introduce anything as unrefined as a bushman or as squat and humourless as a sheep into this world. Esson's reflections of 1923 also suggested his attraction to another view of the artist's ethos which belonged more to the café society of Paris than to the era of Wilde and the Yellow Book of I 894-7. This other world was, in Esson's view, an intense and crowded one, peopled by Bohemian artists and sustained by fierce controversies about Art.

The cast of Esson's mind in this period is revealed in an article he wrote to the Bulletin early in I904 entitled "A "Young Australia" Party' in which he announced that politics in Australia left him cold. $^{\mathrm{a}}$ He looked with distaste upon both the Conservatives and the Liberals and declared with a smartly cynical flourish that they could only be told apart by the fact that the 'Conservatives wear belltoppers and the Liberals boxers'. This left the Labor Party, but Esson averred that it was not 'our' party and explained that:

The aesthetic difference between us is too great. The Trades Hall makes too much of the 'workers'. The 'worker' is useful and necessary, but he is not the end of civilisation; he is the beginning .... He hates ideas, metaphysics and embroidered waistcoats.

The only conclusion was that those who shared Esson's interests and abilities were left with nothing to engage their imagination. The remedy was a Young Australia Nationalist Party 'that will be 


\section{Bushed}

more radical than the workers and more cultured than the Conservatives'. The new party would aim 'To kindle the flame of Australian nationhood' and its membership would comprise 'university and professional men, scholars, artists, reformers, radicals, socialists, and Bohemian poets'. Esson concluded his article with the prediction that the new party would advocate 'the socialisation of the land, mines, manufactures, ships, machinery, and means of production and distribution'.

At least as early as I9oo Esson was known to his student friends at Melbourne University as a socialist. ${ }^{9}$ The influence of his key text at this time, Oscar Wilde's, The Soul of Man Under Socialism, is evident in the style and emphasis of his article on a Young Australia Party. Wilde argued that true socialism would enable men to develop their personalities much as exceptional creative artists like Byron, Shelley, Browning, Victor Hugo and Baudelaire had managed to do in the demeaning conditions of their time. The principle of creative growth was the centre-piece of Wilde's argument and the only standard for true individualism. He saw no good in private property for it encumbered one section of the community and starved another. Once it was abolished, Wilde predicted that nobody would 'waste his life in accumulating things, and the symbols for things. One will live. To live is the rarest thing in the world'. ${ }^{10}$ Wilde's views probably fostered Esson's early contempt for public opinion and his profound admiration of the creative artist. Moreover, it is evident that in The Soul of Man Under Socialism, Esson found a definition of socialism that accorded with his own desire to be a poet. This definition enabled him to suggest that, rightly considered, creativity, socialism and true nationalism were all aspects of man's ultimate desire to live, in Wilde's words, 'intensely, fully, perfectly'.

Esson struck a different artistic pose in a poem published in the Bulletin several weeks after his Young Australia Party article. Life in this poem is certainly full and intense, but the final result is not Wildean perfection, but weariness and a yearning for the oblivion that only death could bring. At twenty-four Esson wrote:

I have led the life, I am weary, I have rioted with the throng

And worn the crown of triumph and woven the garlands of song. ${ }^{11}$

Esson's early poetry was well received by the two leading 


\section{Dream and Disillusion}

Bohemian poets of the day in Australia, Victor Daley and Roderic Quinn. E.J. Brady, versifier, boaster, and publicist, recorded that Esson was offered membership of various Sydney clubs on the basis of his poetic achievements. He added that 'such honours, at the time, were extended only to the elect'. ${ }^{12}$ The comment refers less to a coterie dedicated to high literary standards than a looser fraternity of artists who enjoyed good cheap meals, wine and jovial company. Such a world was able to corrupt a young poet susceptible to careless praise, particularly if the standard of literary judgment was as eccentric as Brady's own. Brady insisted in later life that he had met a 'great many' literary geniuses in Australian letters. ${ }^{13}$ He classed Victor Daley with Keats and challenged his critics to find 'any thirty poems from any contemporary poet in the world as perfect as thirty of Roderic Quinn's best ...' He might well have rested his claims there, but understatement was not his gift and he further challenged those who sneered at Australian literature to discover 'anything at all to equal the output of Australian poets between 1890 and 1930 A.D. ... ' 14 With Brady as a friend and encourager Esson could hardly have escaped the title of genius.

The absurd extremes of literary boosting were entertainingly satirised by Hugh McCrae in an undated letter to A.G. Stephens around I906. McCrae wrote of Brady's 'latest madness'; a writers' colony at Mallacouta Inlet which involved Louis Esson. He pictured the scene:

Private printing press, $£ .5$ a week all round, work not indispensable, free sunsets and none of the cruel distractions ordinary honest men have to face .... Esson is his fellow lunatic .... What a race of Spartans we would raise on idiotic methods of this sort. Every poet his veranda post.

Can't you see the Brady-Esson Sanatorium for Decayed Dreamers? Beer spouting from Government bores everywhere. Sandwiches, air-fans and silk wrappers. Bayldon on eiderdown communing with the soul of Daley. Quinn supported on the laps of two angels. Norman Lilley handing bananas round with words of praise and encouragement .... The two heads of the establishment pouring honey in each other's hair.

McCrae added some basic advice: 'To be a little more practicable I would suggest an earnest attempt to work.' ${ }^{15}$ Esson was soon to give himself similar advice.

Louis Esson did not have to rely on Sydney friends and Sydney clubs for his Bohemian atmosphere. Melbourne also had its Bohemian enclave for the creative writer at Fasoli's café in Lonsdale 


\section{Bushed}

Street. The café generated enough Bohemian enthusiasm to produce a magazine, but it lasted only one issue and was undated. The magazine, flippantly titled The Waddy with which is incorporated 'The Salami' Neutral but Biased, contained two poems by Louis Esson who was regarded as the poet of the café. Both poems made their appeal to a fraternity whose interests and values had set them apart from the middle class and its pre-occupations. ${ }^{16}$

In a later verse tribute to the café, Esson celebrated the uniqueness of Fasoli's and the sense it gave of a new world in Melbourne alive with all the vibrancy which he imagined was characteristic of artistic life in Europe. Esson revelled in the crowded atmosphere of the café, its conversations in many languages, its diversity and continental food and wine. ${ }^{17}$ An editorial in the Melbourne Socialist in 1908 shared this enthusiasm, describing socialists drinking wine in the café and conversing in lively fashion with 'comrades of other lands' ${ }^{18}$ Although these accounts reveal a keen sense of participation in a world that evoked art and life, the atmosphere was rather self-consciously cosmopolitan.

It is difficult to establish when Esson first added an interest in Irish drama to the aspirations, enthusiasms and odd projects which already concerned him as a young man. The first evidence of such an interest was in a letter of Maurice Brodzky's, editor of the magazine Table Talk, to A.G. Stephens in November I904. Brodzky explained that his son, Leon Herbert Spencer Brodzky (later, Spencer Brodney) and Louis Esson were in Paris and that both were possessed by the possibilities of a new drama. 'The two young reformers', Brodzky wrote with fatherly affection, 'mean to revolutionize the English stage. They are under the patronage of Lady Gregory and the tutelage of Yeats.'19 Earlier in 1904, when Louis Esson was already in Paris, Leon Brodzky delivered a paper to the Australian Literature Society on the need for an Australian drama. The Irish example may well have inspired this address. Immediately after the lecture a small, excited group took Brodzky to a nearby café where they discussed what needed to be done and there and then formed what was called the Australian Theatre Society. ${ }^{20}$

Whatever his previous knowledge of Synge, the crucial event for Esson was his meeting with the dramatist in London in 1905. Esson later recalled that Synge

despised anything abstract and cosmopolitan, and thought every country had its own material for literature. $\mathrm{He}$ was interested in the little I could tell him of the life of the bush .... 


\section{Dream and Disillusion}

W.B. Yeats, who was gathering his forces together to build up a real Irish literature and drama, said the same thing. ${ }^{21}$

The visit to Paris and London had come soon after his article on the Bulletin about the need for poets, scholars and socialists to form a cohesive group whose special function was to advance the cause of cultivation, art and elegance in Australia. However, in London Esson was told to leave cosmopolitanism, abstraction, the life of the cities and the world of coteries, clubs, garrets, studios and cafés which had given him so much pleasure and return to the 'sometimes alluring, but rather vague and empty' land he had left. He had now to believe that 'every country had its own material for literature', even Australia. It remains a point for speculation whether the 'Brady-Esson Sanatorium for Decayed-Dreamers', as McCrae satirised the project, was among Esson's first moves to carry out Synge's advice.

For a man as inadequately prepared for the observation of bush life as Louis Esson, Synge's ideas were probably difficult to apply. He might well have wondered, as he strolled around Mallacouta Inlet, where he would find the settled ways and folk customs which had engaged Synge's imagination in the Aran Islands. An article Esson wrote for the Bulletin soon after his return from London suggests that he used Synge's advice as an excuse for stridently patriotic sentiments. Whereas in his 1904 article the 'true Australian nationalists' were scholars and poets whose concern was with a cultivated socialism, the later definition of an Australian was far more inclusive. Esson wrote:

I include anybody as Australian who has faith in Australia; desires to live violently and enthusiastically in it (if possible); has solid Australian sentiment; is interested in things Australian - history, exploration, cities, the bush, politics, arts, personalities, public debt - everything; who buys local goods (when they're there); who doesn't think gum trees 'hideous' and our landscape 'all the same'; who believes the people here can run their country better than outsiders can tell them; who lives, works, thinks and dreams Australian, and is quite cheerful about it ....

If a man or woman doesn't find this country the most interesting on the map (that is, for him or her) and doesn't rejoice and revel in being here, he or she had better depart for London or Japan or Spain (so romantic; they play guitars there!) They're no good here. They're big blots - public nuisances. ${ }^{22}$

In his forced enthusiasm Esson almost managed a parody of the qualities he was intent on defending. 


\section{Bushed}

Esson's demands upon the Australian coincided with the strident patriotism of the Bulletin following the defeat in 1905 of the Russians in the Russo-Japanese war. The Japanese 'monkey' emerged from the Bulletin as an alarming threat to Australian security and this journal considered it scandalous that Australians seemed impervious to the danger. Australia, it declared, 'drifts to its fate calmly. It is infected with "national agnosticism"' . ${ }^{23}$ In November I905 the Bulletin ran a full page cartoon announcing that drink and betting were leading Australian men down the steep hill 'to perdition'.24 In the circumstances a strong patriotism was recommended as an effective antidote to deficiencies in the national character. The Bulletin was not alone in its statements. Shortly before its patriotic cartoon appeared, Alfred Deakin, soon to be Australia's new Prime Minister, criticised Australian indifference to matters of defence. His statement was later published in the Melbourne Herald where it received 'great publicity'. ${ }^{25}$

The call upon patriotic emotions helped shift the literary emphasis among Bulletin writers. There was a feeling that old Bohemian days had gone and were replaced by sterner times. Victor Daley, the veteran Bohemian, had died in Sydney on 29 December 1905 after a long illness from tuberculosis and a diseased liver. In $19^{13}$, Henry Lawson considered that Bohemia had been buried with Daley. ${ }^{26}$ In February 1907, Grant Hervey wrote in the Gadfly of a new school of Australian writers who had become Australian nationalists: 'a school which surmounts all obstacles'. Hervey emphasised the new sense of discipline which overcame the hesitations and neuroses of the old Bohemia. ${ }^{27}$ Albert Dorrington hurried in to support Hervey. In March 1907 he wrote: 'A better class of writers - harder-headed, stronger willed, are coming up. There's less beer in Bohemia now, and Bohemia's the better for it. ${ }^{28}$

Judging by his writing in this period Louis Esson identified himself with this 'new school' of writers. In April 1906 he contributed a poem titled 'A Ballade of Bohemia (Old Style)', to the Bulletin which announced his disillusionment with the old Bohemia. He complained that many of the habitués of Bohemia had betrayed their aspirations by indolence and hollow boasts: 'Would-be's were cheap in the good old days'. ${ }^{29}$ In August r 906, Esson published a short story in the Bulletin which again satirised Bohemia and its tendency to retreat from the world after a self-righteous sneer at philistinism..$^{30}$

Esson's more aggressively patriotic mood is sustained in much 


\section{Dream and Disillusion}

of the verse which he published in the Bulletin during 1907. Hard. headed patriotism and fear of Asia were key themes. ${ }^{31}$ There was also a fascination with the figure who defied limitation, as in his poem, 'The Immigrant'. Here, Esson portrayed the immigrant as the discoverer of new possibilities. In this view, life in the old world was depicted as 'cramped and wan', allowing no room for 'man as man'. ${ }^{32}$ This theme was differently applied in a poem entitled 'North and South' in which Esson contrasted the indigenous north and the derived south. The north provided room for the spirit of man to expand and find expression, whereas the south was 'sleepy Saxon', 'old English' and suburban. ${ }^{33}$

The public affirmations in Esson's patriotic poetry were accompanied by private doubts. In a letter to Leon Brodzky early in 1907 Esson made it clear that he was in search of a better understanding of what it was to be a writer. Aspects of Australia tantalised him, for he sensed that they invited interpretation more subtle than his own powers allowed. Characteristically, Esson was also critical of the conditions in which the writer had to work in Australia. He wrote:

We have too small an audience. Otherwise life goes very well. The country is full of suggestions, - character and fantasy. It seems to cry out for stories and poems. But the people know nothing. We have no standards. What I miss, is somebody to talk literature with, to criticize my stuff and ideas, and to give new stimulus. I know nobody here interested in literature as literature .... No outsider knows anything about the craft. And those in it are mainly journalists with that fatal 'nose for news' or freelance chasing coin. I seldom talk literature with anybody. ${ }^{34}$

In the same letter Esson set down his plans for the new year:

$T$ 'is the time of Good Resolutions. My intentions are for the New Year.

(I) To Work

(2) To Work a great deal.

(3) To Work Well

(4) To Live Quietly

(5) To Study, - Letters, Philosophy, Art etc.

(6) To discard bad habits, Foolish Friends etc. - in order to work joyously without interruption.

(7) To create with joy.

The emphasis upon work revealed both a determination to alter languid habits and a weakening of Esson's contempt for what he 


\section{Bushed}

had termed 'mere work' in his Young Australia Party article. It is not clear who the foolish friends were, but on Hugh McCrae's evidence, E.J. Brady would have been a hard man to overlook.

The promise of a finer Australian future which pervaded Esson's work of 1907 was developed more fully in an article of his titled 'Terra Australis: Fragments of a Conversation', published in Heart of the Rose in 1907. Esson defended the literary prospects of a nation with no established peasantry or aristocracy. and with no glorious spiritual or military traditions on the grounds that Australia's relative 'emptiness' was a virtue considering the 'worn out things' like novels, plays, pictures and cast-off fashions which had been 'stuffed' into the nation. Since he believed that 'the Prometheus of the Australian Imagination was fettered to the mountain of British Fact', isolation from the source of contamination had advantages. Yet, conscious that isolation could breed insularity, he also cited Bernard O'Dowd's view that Australia knew no geographic boundaries, but was wherever the finest spirit of man had manifested itself. Basically, Esson maintained that a certain freedom from old world traditions gave the Australian writer an opportunity to choose what was best in the past for his own purposes. His testament was summarised as follows:

The future is very rich - virgin Ocean - primeval Bush. The old worlds - Europe, Asia - lose touch with reality. Their pulse grows feeble: they repeat only the thoughts of their ancestors, living at Second-hand. Australia feels the life-giving sun in her blood. Will not the statement be more vivid, more splendid, with a flush of the tropics, luxuriant, full of colour and melody, with space and freedom in it, joyous, a thing of beauty? ${ }^{35}$

This prediction of the coming style reflected an attachment to complexity and contrast which was more attuned to the tropical landscapes of Australia than the drier, sparer regions which were so important in Lawson's writing. Esson's luxuriant and bountiful view of Australia was replaced by more austere and understated images in later writings which he felt were nearer to the spirit of the true Australia.

The Heart of the Rose article confirms a shift in Louis Esson's attitude to Europe. He no longer saw the cultural traditions of Europe confined geographically within European borders but now considered the spirit of a European past would illuminate the Australian future, a future that would be part of the continuing search of European man for a deeper understanding of his humanity. 


\section{Dream and Disillusion}

Psychologically, this attitude to European tradition gave Esson more room to consider Australian life and its possibilities for art than the old Bohemia had done. It relieved Esson's feelings of national inferiority and encouraged him in his task of working as an Australian artist. He now felt that an Australian artist could be a man of stature, not merely the fringe dweller of the old Bohemia. For a man always troubled by Australia's cultural backwardness, this change was a crucial one. Even so, while it was of some value to discover a manifesto declaring what Australian writing could accomplish, the next phase of creativity and accomplishment was a more demanding one.

One effect of Esson's newly found sense of purpose was his growing dissatisfaction with the Bulletin. This was partly a reflection of his dislike of Arthur Adams who had taken over as editor of the Bulletin's Red Page in 1906. In a letter to Leon Brodzky in I909 Esson described Adams as 'a vain little man ... with no personality ... a person of no importance... ', adding that his Red Page 'has been the despair and amusement of everybody'. In the same letter Esson condemned the Bulletin as 'senile' and declared that he was 'really pleased the Bulletin is dead. It was bad for Australia to be obsessed by one publication ... '. ${ }^{36}$ After 1909 , Esson made fewer contributions to the Bulletin. ${ }^{37}$ This defiance was encouraged by the fact that he had just found a new job which seemingly lessened his need to write 'scrappy pars, topical verse, etc'. ${ }^{38}$ Evidently, Esson had felt compelled to write according to Bulletin requirements, a frustrating demand for a young writer in search of his own style.

Esson was not alone among his contemporaries in criticising the Bulletin. In a letter to Leon Brodzky in 1905 Hugh McKay disputed the view that the Bulletin was 'the great encourager of budding talent'. He was critical of the magazine as 'a blunter and a leveller'. 'Verse for the Bulletin', he wrote, 'has to be of a certain length, a certain metre, a certain tone of feeling, a certain word usage ... a certain lightness of treatment .... It becomes mechanical ... '. With the system revealed, McKay advised Brodzky on the production of 'machine-made' Bulletin contributions. He suggested several styles, among them the ballad or 'local hogwash'. McKay also had techniques which produced a serviceable Bulletin love story:

Make the rhythm full, rich, bilious: call the moon a 'crescent sail of Eden' and the waves 'the beating seconds of the sea'. Mention the love that pulses fierce deep and hot in passions swelling breasts but avoid legs and do not call them juicy ('For 


\section{Bushed}

that which is Chaste Below the waist Is immodest above the knee'). Arms however may be allowed to 'cling', and hair (headhair only) may be instanced as 'blown' . . . 'amorously' perhaps 'athwart' something or other. ${ }^{39}$

By the end of 1909, McKay's attack on the Bulletin had grown more aggressive. He lamented its 'terrible degeneration', feeling that it had become 'prolix, long-winded, conservative, indigestible, "settled-down" and dull'.40 The opposition of McKay and Esson to the Bulletin arose, in part, from the importance they attributed to the individuality of the artist. In the case of the Bulletin, they felt that the journal overruled the writer.

During 1909 Esson grew more dissatisfied with the Bulletin and more intent on his own creative development. He wanted to write and he had the opportunity. This was also the year of Bernard O'Dowd's address on 'Poetry Militant' which proved a great encouragement and inspiration to Louis Esson. There was a shared sense of urgency, even of alarm, in the need to assign the creative artist his proper place in society. Early in $19 \mathrm{I}$, Esson declared that O'Dowd was Australia's greatest poet, for his poetry was 'the most challenging, the most profound and the most proletarian' in Australia. It was not that O'Dowd chose the proletariat for his subject matter. He did not. He was considered proletarian because he was a 'rebel' and had qualities 'of initiative, of courage, of originality, of sincerity, of imperativeness' in his work. ${ }^{41}$ The term 'proletarian' described an ideal available to the artist, which was different from the ideal associated with the term 'cultivated'. It also had a different meaning from 'working-class' which described a reality which Esson found unpleasant. For Esson, O'Dowd exemplified the Australian literary man. He was European in the breadth of his culture and national in the depth of his concern for the future of man in Australia. O'Dowd lived in the hope of an Australian future and above all, he was a passionate advocate of the creative artist.

Louis Esson's concept of the artist is evident in a series of eight articles written for the Socialist in I9I I in which he asserted that the artist was the true socialist, a view he had expressed in his 'Young Australia Party' article. Further, it is clear from the I9I I articles that Esson considered the urban working class just as hostile to his purposes as they had been in 1904. Of the factory worker he wrote: 'He has no spirit of revolt. His imagination is dulled; he accepts the Factory as something inevitable ... '42 In Esson's definition, 


\section{Dream and Disillusion}

the factory worker was not proletarian. Esson continued his attack in an article on the 8-hour day with the claim that Australia was the country of 'the satisfied working man. And the satisfied working man is a cowardly Conservative .... He hates Internationalism. $\mathrm{He}$ is British and Imperialistic'.43 By implication Esson argued that, ideally, it was Australian to rebel, to resist Imperialism and to pursue International Socialism. These qualities, however, were not dominant in Australian society. Esson knew they were not and constantly lamented the fact: While it would be too schematic to suggest that Esson set out to identify his ideal man with the ideal Australian, this was the tendency of his thought.

Esson's real dissatisfaction was reserved for the middle class. In terms of the ideal, they were least Australian. He examined them through their institution, 'The Suburban Home' and growled:

The vaunted purity of the suburban home is nothing but a spiritual Sahara. It stifles the devil-may-care spirit, the Dionysean, the creative spirit. It denounces Art, enthusiasm, heroic virtue. The Muses are immolated on its altar of respectability.

Nothing in our present society is wildly desirable, but, if one had the choice, it would be better to live in a slum area than in a bourgeois suburb. The slums have more character, perhaps base character, and decidedly more potentialities. Life is more vivid and picturesque there. People dance, and have passions, and live, in a sense, dangerously. In the suburbs all is repression, stagnation - a moral morgue. ${ }^{44}$

Spiritually, Esson's world was a polarised one. If there was not abundant life and vivid passion there was no life at all. He did not sympathise with the proposition that suburban life could have stability, order, purpose and emotional fulfilment; or that it could produce people capable of reasoned and intelligent political opinions. Nor did he live in a slum.

There were inconsistencies in Esson's attitude to slum life. Several years before his Socialist articles he had turned his attention to the state of Melbourne where he found much that alarmed him including opium dens, sly grog shops and two-up schools. Faced by this evidence of low life Esson asserted that 'anything that rots the fibre of a nation should be grubbed out' and he was concerned to show the people involved that 'thieving and loafing was a fools' game'. ${ }^{45}$ While Esson denounced slums for producing wasters, he also celebrated them as a breeding ground for wayward genius. These attitudes are not easily reconciled. However, the celebration 


\section{Bushed}

of slum life is best seen as a romantic projection of Esson's continuing hostility to middle-class life. In 1908 he wrote:

Villon, Burns, Walt Whitman, Maxim Gorki, Henry Lawson the alleys have had no want of bards. And though bounded by the pub, the gambling den, the 'jug,' and the morgue, there is such spice of adventure in the life, such hazardous contrasts, such anarchic freedom that few hardened habitués would exchange it for the humdrum paths of respectability. ${ }^{40}$

Henry Lawson's appearance in this group of writers is instructive for it suggests the process by which Esson came to accept Lawson as a writer. Lawson had been beneath Esson's notice as long as he judged art in terms of the refined wit of Oscar Wilde, but he became acceptable as a figure who issued from the lower depths of society to challenge respectability.

Esson also found fault in his Socialist articles with Parliament, the newspaper, and the church. 'The political machine', he wrote, 'is itself a class institution. It is not in political action, but in industrial organization, that the real strength of the workers lies. ${ }^{37}$ $\mathrm{He}$ accused the newspapers of fostering 'one of the most lamentable features of commercialism' namely, a chaotic view of life. He held them largely responsible for 'working class ignorance of International Socialism'. ${ }^{48}$ By contrast Esson found the pub, although flawed, the most satisfactory of existing institutions. 'Drink', he declared roundly 'makes every man a poet or a hero'. It lifted ordinary men to the extraordinary and exceptional men almost to saintliness. While the pub enhanced man, Esson believed that the church in its emphasis upon respectability and in its repressive morality diminished him..$^{49}$

There was a dichotomy in Esson's view of the world between that which was present, real, socially accepted but somehow stagnant, and the poetic ideal of a society which. would be lifegiving, creative and energetic. There was the suburban 'spiritual Sahara' or the life, movement and activity of the creative society. These and similar beliefs are evident in Esson's play, The Time is Not Yet Ripe, which was first performed by the Melbourne Repertory Theatre under the direction of Gregan McMahon on 23 July $1912 .{ }^{50}$

The plot of this satire on Parliamentary Democracy can be stated simply. Sydney Barrett, a revolutionary socialist and wealthy squatter, intends to stand as a socialist candidate for the electorate of Wombat. He learns that his fiancée, Doris Quiverton, daughter 


\section{Dream and Disillusion}

of the Liberal Prime Minister, has been nominated to stand for the same electorate by the Anti-Socialist League who are concerned about the growing strength of the socialists. However, Sir John Quiverton is returned as the Leader of a triumphantly successful Liberal Party. Sydney Barrett fails hopelessly at the polls, but manages to salvage his honour on the ground that he had not sacrificed his principles. Finally, Sydney and Doris decide that love is more congenial than politics and renounce political ambition.

In his rebellious outbursts against purity, home life, Liberal politics, and parliament, the key figure of the play, Sydney Barrett, has obvious similarities with Louis Esson. Barrett's socialism was a protest against conventional morality, rather than poverty or class oppression. The only Marxist in the play was an unimpressive fellow who was finally shown the error of his ways. ${ }^{51}$ Like Esson, Barrett had contradictory feelings about Australia. In the first act we learn that Barrett had returned to Australia after an absence of four years. Although 'full of a fine enthusiasm' on his return, he was disturbed to find the country

stagnant, decadent, - and the young Australian, with his bright, fresh mind, untramelled by the traditions of the past - that is the current phrase - repeating all the popular superstitions, from beer to bishops, of his fog-bound ancestors. ${ }^{52}$

Australians were not the independent spirits he had supposed them to be. They were 'unoriginal' and 'uninteresting' and Australia was no better than 'an outer suburb of Brixton'. Esson presented Barrett as a frustrated enthusiast; a man driven to extremes, yet deserving sympathy. He was a man who required the support of a livelier national feeling.

Towards the end of the play we find Barrett on the soap box, declaring that he did not intend to talk politics, for he did not believe in it. Socialism he claimed meant 'much more than an economic change of Society' and thus went far beyond the scope of practical politics. Accordingly, Barrett opposed the power and influence of the practical man:

Why, the curse of this country, and every other country, is the plain practical common sense man with his low standards and narrow outlook. We want poets, dreamers, builders of ideals. The national need is a thoroughly unpractical man. ${ }^{53}$

The audience thought otherwise. Interjectors suggested he was 
mad and should have his 'head read', but Barrett pursued his theme. The leaders had failed, he insisted 'because they have tried to please you by getting down to your own level'.54 Instead, the people should support the candidate who did not set out to please them.

The electorate of Wombat confirmed the unpopularity of Sydney Barrett's beliefs. He lost his deposit, but strengthened his contempt for Parliament. 'Parliament', he declared, 'does not represent the people. Parliament represents the stupidity of the people'. ${ }^{55}$ His opinion was confirmed after watching the celebrations of the Liberal victory. 'Rule Britannia' was played amid 'shouts, cheers, trumpets' and Barrett concluded: 'The masses still think Imperially.'56 Disappointed, he told Doris that he was 'tired of the proletariat, tired of Australia, Australia is too British, the proletariat is too conservative'. ${ }^{57}$ Although Barrett despaired of politics, we are encouraged to believe that he did not despair of life, love and laughter.

Overall, The Time is Not Yet Ripe was applauded. The Argus review referred to the crowded theatre and noted that the play was 'acted with unusual spirit, [and] was very well received indeed, and the applause throughout was of the heartiest description'. 58 The Bulletin conceded that Esson revealed 'a healthy talent for full sized playwrighting', but added a more critical note in a second review: 'As a satire on Australian politics it lacks the one necessary touch - that we should be able to believe that its characters are alive'. ${ }^{59}$ This criticism has some point for it touched upon Esson's tendency either to escape or justify Australian society, without first having stood back and observed its workings. However, with sensitive acting and careful direction Sydney Barrett could well have emerged as a plausible and well sustained character. There was certainly evidence in the play that with more practice Esson could have deepened his characterisation and given Melbourne theatre audiences plays which penetrated the dilemmas and foibles of their own society.

The publication and performance of The Time is Not Yet Ripe in 1912 coincided with the appearance of Esson's Three Short Plays. Both publications were an outcome of his resolution in $19{ }^{\circ} 7$ to discard bad habits and foolish friends and do some work. One 'foolish friend' who seemed piqued by this stern resolve was Hugh McKay, who complained about Esson in a letter to Brodzky towards the end of 1908 : 


\section{Dream and Disillusion}

Away from work I like to be a fool, or at least human; but Louis has no ideas beyond the chilly bound of literature and cannot condescend to smile at anything below the intricate humour of Browning. ${ }^{60}$

Esson managed to adhere to his work plan. Towards the end of I 9 I I he informed A.G. Stephens that he had devoted the year to drama and added: 'Really I take it very seriously' ${ }^{61} \mathrm{His}$ efforts did not go unrewarded for his Three Short Plays was a literary event greeted in the Bulletin with an article titled 'The Australian Drama - In Sight'. The Bulletin reviewer described Dead Timber as 'a playlet that compares with the first offerings of the Irish dramatic revival. It has the simplicity; the inevitability, of art' ${ }^{62}$ Later, in a review of his Red Gums and Other Verses it was noted that: 'It is almost unnecessary to add that Esson has, in Australia, already a reputation' ${ }^{63}$ He was then in his early thirties.

There was a big difference between The Time is Not Yet Ripe and Three Short Plays. The political satire was finished later, but represented an earlier phase in Esson's development as a dramatist. In a letter to A.G. Stephens in I 12 Esson wrote that he had 'just finished a political comedy that seems five years old in style'. This was the beginning of a long dissatisfaction with a play which came to represent a style and an attitude from which Esson wished to be dissociated. He thought differently of Three Short Plays, declaring, in his letter to Stephens, that they 'are no more than studies, but they suggest the way I wish to write'. Earlier in this letter he had made his shift from the abstract to the realistic more explicit:

it will be a fearsome blow if I find I am only a sentimental old-fashioned romanticist like Shaw ... instead of a symbolist realist like Euripides. I am beginning to find a style - that is all - but often I slip back into old methods. ${ }^{64}$

The implications of the new style are evident in Dead Timber. It is set in the bush and the chief character is a Gippsland farmer, a man defeated by the land and emotionally isolated from his family. After a relentless sequence of tragic events he commits suicide. Esson overloaded the play with gloom and it is difficult to feel convinced either by the circumstances or by the emotional atmosphere of the play. Yet, the tragic excesses of Dead Timber demonstrate how earnest Esson had been in removing ideas and flashes of wit from the dialogue. The new style was confirmed by Esson's public rejection of Shaw in an article to the Socialist in 1913 : 


\section{Bushed}

$\mathrm{He}$ is a clever juggler with what are called 'ideas' - that is merely intellectual conceptions ... but he has no profound feeling for life itself, which, as Bergson tells us, 'overflows the intellect'. In Shaw's case the intellect always overflows life. ${ }^{63}$

It is far from self-evident that in suppressing 'old methods' Esson had made a choice which suited his temperament and abilities. Hugh Esson described his father as a small man physically, given to daydreams about sport; a man never quite tough enough for the real world and certainly incapable of carrying a swag. A family story records that when Louis Esson first cleaned his shoes at the age of twenty he used stove black instead of boot polish. The favoured financial circumstances in which Esson grew to young manhood gave him no understanding of poverty or the pressures upon those whose lives were given over to hard and often menial work. Moreover, Louis Esson was raised in the city and was dependent upon its amenities. He had little knowledge of the bush and no real capacity to endure its privations. By upbringing and temperament Esson was ill-equipped to explore themes which he came to see as distinctively Australian. ${ }^{66}$

In 1914, Esson insisted that the 'authentic Australian play' should be distinguished by a 'real atmosphere', by 'space and sunshine, wild nature or primitive character' and by themes close to 'the earth and reality'. ${ }^{67}$ These views arose out of Esson's search for distinctively Australian themes, yet they cannot be isolated from the social context and preoccupations of the man who produced them. In the years before World War I Esson was a young man with a future to make. One of his concerns was to find room enough for his creative ambitions to grow and his hopes to prosper. However, Esson was exasperated by the lack of opportunities in Melbourne and the city's claustrophobic morality. He felt boxed in. Suburbia appalled him, for in his eyes it represented timidity, conformity and a willingness to accept confinement. He felt no spirit of kinship with people whom he considered narrow and predictable. At least, he believed, the working class was still capable of growth and development. He saw them as a possible source of change. As a young man anxious for change in his own life, Louis Esson came to feel some kinship for the working man. He also developed the view that those who lived beyond the cities were there because they were too proud and rebellious to submit to city routines. They too became his spiritual companions; his imagined associates in a finer Australia. 


\section{Dream and Disillusion}

Behind Esson's attacks upon the mediocrity of Australian society, his growing contempt for ideas and his preference for life itself, lay a deeper self-distrust rooted in his middle-class origins in a colonial culture. Esson felt that this background weakened his hold on life and impoverished his powers of imagination. Impatient for success and troubled by doubts about the worth of his writing, Esson abandoned the style of The Time is Not Yet Ripe for what he considered the more elemental themes of his bush plays. The change did not cure Esson's impatience, nor did it bring him into touch with themes peculiarly suited to his own talent. Indeed, the change carried Esson further from the issues which were central to his understanding of the human impulses behind the search for a 'finer Australia'. It lessened his opportunities to probe, with a dramatist's eye, the personal and social realities of freedom and bondage, creative growth and mental stagnation, fulfilment and failure. It was a demanding task to do justice to the exacting complexity of these themes. Under the pressure of impatience and self-doubt and wanting to feel the psychological repose of being truly Australian, Esson abandoned this task for what he regarded as the more reassuringly simple and artistically modern themes of his bush plays. 


\section{Vance Palmer: The Beginnings of a Literary Socialist}

As a man of letters and a citizen Vance Palmer has been highly praised. He and his wife Nettie are the only writers to have been honoured with a special issue of Meanjin Quarterly (No. 2, 1959) devoted entirely to their own writings. Earlier in the r95os Palmer had refused an O.B.E. and Melbourne University was about to recognise formally Palmer's contribution to the arts in Australia when he died in 1959. ${ }^{1}$ In that year C. B. Christesen, editor of Meanjin, described Palmer as 'the most distinguished man of letters Australia has so far produced', while in his recent Boyer lectures Sir Keith Hancock singled out 'the Palmer standard' for particular praise. ${ }^{2}$

Much of the favourable comment upon Palmer's achievement stems from the belief that he was a key figure at a crucial stage of the nation's cultural development. In this view Palmer is seen as a link with what was best in the 1890 s. Both Heseltine and Serle referred to Palmer's 'heroic' career in Australian letters. ${ }^{3}$ H. M. Green also praised Palmer's varied talent and sustained career and located him in the 'Lawson-Furphy tradition' as did Serle." John Barnes wrote of Palmer as 'a leader of the third generation of literary pioneers, free of the twin evils of obsequious colonialism and truculent nationalism', while in an essay on Palmer's short stories Arthur Phillips observed that as early as 19 I 5 he showed skill in handling 'Australian interpretation' and an ability to keep his 'undercurrent of Australian pride' from becoming 'obtrusive' or 'jingoistic'. 5

These views may be summarised as follows: as a writer and critic Vance Palmer interpreted the spirit of the I8gos to later generations of Australians in a manner which affirmed the enduring qualities of Lawson and Furphy. Moreover, in his own quiet acceptance of national themes and in his respect for the craft of letters Palmer did much to civilise the sometimes strident nationalism apparent 


\section{Dream and Disillusion}

in the Bulletin of the 18 os. By his own practice and by sustained example over many difficult years, Palmer made Australian literature more worthy of respect.

In most critical writings on Palmer his democratic convictions are explained merely by reference to the 'Lawson-Furphy tradition', while the actual content of his ideas has largely passed unexamined. Heseltine pointed to English influences when he alluded to Palmer's 'liberal humanist ethos', but declared that although it was 'the keystone of his understanding of the world'b it remained 'sadly unexamined'.7 John Barnes was no less diffident in his effort to describe Palmer's beliefs. After quoting an article in which Palmer wrote of the sardonic, idealistic but tongue-tied Australian expressed in the writings of Lawson, O'Dowd, Bedford and Collins, Barnes commented: 'This romantic conception appears to have had a strong personal value for Vance Palmer, and to have defined his sense of his own role in Australian life as an "ardent nationalist" '. However, Barnes makes no attempt to define this romantic conception or to account for its special appeal to Palmer as an Australian nationalist. The reader is merely informed that: 'From the outset Palmer understood how national feeling was related to literary creation'. ${ }^{8}$ This is improbable and it also avoids the whole question of Palmer's intellectual development.

Critics have made little attempt to analyse the influences which shaped Palmer's style and social philosophy. Most have preferred to isolate key literary influences rather than locate Palmer within his formative intellectual milieu. Arthur Phillips, for example, tended to caricature European literature when he declared that Palmer, like other Australian writers was in revolt against the common European assumption that only the middle-class sophisticate was a fit subject for Literature with a capital L'. 9 Did Kipling, Wells, Bennett, Chesterton, Galsworthy, Shaw, Lawrence or Joyce assume this? While the idea may have marred some European writing, it is misleading to suppose that Australian writers were alone in rejecting this limitation or even unusual in so far as they did so.

Some of the problems inherent in the relationship between an Australian writer and his European counterparts have already been discussed in relation to Louis Esson. As we have seen, Esson contrasted the fading pulse of the old world with vibrant Australian symbols of 'virgin ocean' and 'primeval bush' in order to evoke an illusion of creative scope in a country which otherwise might be 


\section{Vance Palmer}

considered indifferent to the imagination. By denigrating Europe, much as Phillips did, Esson hoped to make a case for creativity in Australia, although at the same time he was also critical of the middle-class nature of Australian life. His ideal for the Australian future was thus gradually conceived both in terms of a break from colonial dependence upon European culture and a renunciation of middle-class values. His meeting with Yeats and Synge gave him the authority and the creative principles he needed to express these ideals. As Synge suggested, Esson went to the bush instead of the city for his literary themes. In making this transition, Esson was not defying outside influences but rather co-operating with those influences from a more powerful literary tradition which he considered useful to his purpose.

In many ways Palmer's development as an Australian writer was similar to that of Louis Esson, although the changes appear less obvious and less dramatic. Like Esson the young Vance Palmer dreamed of an ideal independence for Australia. In an article published in Steele Rudd's Magazine in 1905 on 'An Australian National Art', he claimed that: 'We, who have in our power the makings of a glorious nation with no sordid past ... are content to imitate the customs of old degenerate nations, and to let our individuality be obscured by the detestable word "colonial" '.10 For Palmer, as for Esson, the key to the Australian reality lay in the word 'imitation'. Australia was seen as a poor copy of a not very admirable model. Nevertheless, despite the reality, both writers were guided by a higher ideal: their vision of the creative, vital and democratic society that might emerge in the Australia of the future. Merely hoping for these changes, however, did not make them happen. There was always a danger that their idealism might remain no more than the expression of an extravagant faith in the future, coupled with a dismissive attitude to the realities of Australian life.

When, in his I905 article, Palmer turned to the Australian past for guidance, he found only a 'scanty heritage of prose literature'. He disparaged the writings of Ada Cambridge and Mrs Campbell Praed and dismissed both Far the Term of His Natural Life and Geoffrey Hamlyn as suitable models for a future Australian literature. However, he considered Boldrewood's. Robbery Under Arms 'a priceless epic' which held 'all the romance of a romantic period'.

Having diagnosed the patient as culturally unhealthy, Palmer prescribed 'ardent nationalists' rather than 'cultivated writers'. 


\section{Dream and Disillusion}

For these men and women he predicted stirring challenges: 'Theirs is the most glorious task ever conceived - the creating of a whole literature. After all', he continued 'we are a very young people, and are only commencing to find out our characteristics'. Palmer also maintained that the bush would favour an Australian individuality, whereas the city, in making men 'more and more cosmopolitan' presumably shifted the balance away from 'ardent nationalists' towards 'cultivated writers'. Nowhere in his article in Steele Rudd's Magazine did Palmer mention either Furphy or Lawson.

From his article on 'An Australian National Art', it is clear that in 1905 Palmer did not picture himself as the heir to a period of literary awakening in the 1890 , but as a young writer predicting the first stirrings of a new national spirit in Australian writing. 'Even now', he declared, 'the national movement is beginning'. He defended the promise of a finer Australia concealed by colonial habits which brought 'foreign eyes' and 'foreign standards' to judge Australian life. But he was disappointed with Australian culture; the nation seemed impervious to the artistic spirit. He was also concerned at the rarity of folk traditions in Australia, of songs or stories which celebrated 'man's joy in his work'. Palmer attributed the spiritual malaise of Australian life to a remoteness from human fellowship, the natural world and the day-to-day lives of ordinary men and women.

Palmer's diagnosis of the nation's troubles in 1905 corresponded with an estimate of his own shortcomings at about this time. $\mathrm{He}$ confessed to Nettie Higgins in 1912 that 'moral priggishness' was a fault he 'always had to fight against'. He had been ever ready to 'sacrifice the flesh and blood nearest to me to abstract principles often to ideas hardly as real as principles'. Palmer went on to describe how, when he was living with his sister at about the age of sixteen, he insisted that the boy helping them in the house should eat with them in the dining-room instead of in the kitchen. Palmer added that his head was 'full of Whitman and Tolstoy' when he made these demands. They ended in failure. His sister complained that it spoilt her meal-hours and the boy left 'because', Palmer believed, 'he felt uncomfortable in the sitting-room but that didn't matter so long as I was filled with the glow of self-righteousness'. The letter shows a sense of remorse for well-meant but insensitive efforts to achieve a rapport with someone lower on the social scale. In the same letter, Palmer expressed anxieties on his literary 


\section{Vance Palmer}

ambitions. 'Sometimes I think it priggish', he wrote, 'to bother about what kind of stuff I put my name to as if I were some fine gentleman with an eye upon Posterity. '11 With Palmer, as with Esson, there was a nagging self-distrust and lack of conviction about his right to be a writer.

From autobiographical notes written in the 1950s we learn that Palmer, the youngest of eight children, grew up in a family which enjoyed books and reading. ${ }^{12} \mathrm{He}$ described his grandfather as a man whose 'literary' background prompted him to contribute to local magazines and to make "what efforts were possible to prevent the links with old-world culture from snapping ....'. He also pictured his father as a 'studious type' better suited to a quiet position in a library than to his career as a teacher in Queensland country towns. ${ }^{13}$

The young Vance Palmer absorbed the literary interests of his family, although when he attended Ipswich Grammar School his habit of reading temporarily gave way to an interest in sport, particularly cricket. He was at school during the Boer War but few of its echoes seem to have reached Palmer, although he could remember Banjo Paterson's visit to the town and his account of experiences as a war correspondent. He also recalled how his patriotism was fired by a poem of Essex Evans's 'based on an heroic stand of Queenslanders at Eland's River'. But this image was then disturbed by a cartoon in the Bulletin which depicted 'a shipload of returned contingenters, sprawling in drunken disarray on the wharf'. This first distasteful contact with the Bulletin made him avoid the journal for a time, although soon after this period he was drawn to the short stories of Henry Lawson and Steele Rudd and he followed A.G. Stephens's Red Page with close interest. ${ }^{14}$

It is hardly surprising in a family which cherished even the slightest contact with writers that Palmer expressed the wish for a literary career. At fifteen he decided not to go on to Sydney University, for he believed that his chances of becoming a writer were better if he went out into the world and gained some experience of its ways. 'Deep within me', he observed, 'was an ambition to be a writer ... it surged up whenever I thought of the experiences offering themselves in the world outside'. ${ }^{15}$

Palmer's first job as secretary to a decidedly shady medico allowed him a good deal of spare time, much of which he spent reading at the nearby School of Arts Library. He emerges at this time as a bookish youth absorbed by the works of certain novelists 


\section{Dream and Disillusion}

who were supremely conscious of their status as artists. Through George Moore's Avowals Palmer discovered Turgenev, whose works he read exclusively for a time, while 'looking for hints of Turgenev's characters in the streets'. He passed from Turgenev to Balzac, all of whose novels he attempted to read before he was twenty, and from there to Flaubert and Guy de Maupassant. ${ }^{16}$ Given his artistic aspirations and his sustained interest in Balzac, Palmer may have imagined himself a writer of Balzac's type, a man driven by the desire to capture the full diversity of life in art. However, it is also possible that it was the artist's mystique which had attracted him, allowing him to overlook for a time the more difficult task of estimating the sort of writing suited to his abilities and circumstances.

In his autobiographical essays Palmer described his father as a defeated man in terms which recall arguments he had used in his article on 'An Australian National Art' for Steele Rudd's Magazine. He wrote critically of his father and a literary friend as men whose

bookishness went with a complete detachment from the life about them, a disposition to treat it as a comic drama, filled with gnomes and rustics - a drama they had unfortunately become involved in but couldn't take seriously. ${ }^{17}$

Henry Palmer's chief offence in the eyes of his son was his fragile hold upon the life about him; his ignorance of country ways and country people and his dislike of animals. This attitude to his father was a long-standing one. In I9og Palmer wrote of him as the only person he knew who could 'in his letters become entirely emancipated from his local surroundings ...', while in the rg3os he referred to him as 'a symptom and example of the bewildered cultural man in the new social setting of Australia'. ${ }^{18}$ Palmer detected signs of defeat where the literary imagination became a refuge from the world rather than a guide to its richness, even in the commonest routines of daily life.

It is reasonable to suppose that his father's apparent failure was a matter of lasting concern to Palmer which made him anxious to avoid similar shortcomings. He did so, however, within the framework of the family's literary interests. On the evidence of what appears to be a phase drawn from his own youth in the short story titled, 'Branscombe Sisters', it could be argued that Palmer was no less aloof from his surroundings than his father. The reader is returned to the days of 'the first bicycle and the last bustle' when the 
young man of the story was 'filling in cables on a morning paper' and otherwise dividing his time between 'Balzac and the riverfront'. We are told that he had 'little inclination for company' but with 'books, imagination, health', how could he be lonely? It is a friendly portrait of a young man of strong literary inclinations whose pipe, press card and independence gave him an air of worldly-wisdom and precocious maturity. ${ }^{18}$ However, it is possible to see how, with a slight shift of emphasis, the young man could have become the priggish and somewhat superior youth Palmer alluded to in the letter to Nettie Higgins in I9 2.

When he was nineteen Vance Palmer left for London. His objectives in going abroad and his intended period of stay are not clear, although it appears that he saw London as a city of opportunity for an intending writer. In later life when recalling his reasons for going abroad when he did, Palmer stated that Australia at the time 'seemed a hopeless backwater for anyone who had literary ambitions, indeed artistic ambitions of any kind'. ${ }^{20}$ Several slight articles of his had already been published in London magazines and there seemed some hope that he would do better once installed there. ${ }^{21}$ Steele Rudd agreed, arguing that it was difficult for a writer to live by his craft in Australia. ${ }^{22}$ Ironically, in view of his article to Steele Rudd's Magazine, Palmer was to spend almost seven of his next ten years overseas.

Palmer found lodgings in what he called an 'attic' near the British Museum, but which the previous tenant, Lionel Lindsay, described more invitingly as 'a room on the second storey with two windows, a table, fireplace and a clean bed for eight shillings a week ... ' ${ }^{23}$ Palmer's memories of the period were unpleasant ones 'of dreary hack-work carried on far into the night, the sound of rejected manuscripts dropping in through the downstairs door, and the depressing smell of cocoa boiled on a tiny petrol-stove. . . ${ }^{24}$ Addresses by Yeats and Shaw relieved the monotony of this 'grub street' experience, but when in 1910 Palmer recalled London he pictured 'a grey sky, a slovenly street cluttered with papers, and men with mufflers and tweed caps shambling along with their eyes on the pavement'. ${ }^{25}$ His experiences seemed to cure some of his earlier romanticism. 'I was no longer infected', he later wrote drily, "by the romantic notion that writing was in itself a glamorous pursuit, irrespective of what was written'. ${ }^{26}$

Albert Dorrington's tough experiences in London give some clues to the problems Palmer must have faced as a young, in- 


\section{Dream and Disillusion}

experienced Australian in Fleet Street. ${ }^{27}$ Dorrington arrived in London in 1907 with several novels behind him, manuscripts in his bag and the expectation of higher rates for his work than was paid in Australian papers. However, he felt quite alien in Fleet Street and found his Australian background an embarrassment. His experience had forced him to conclude that there was no market in England or America for Australian short stories as there were a dozen editors who would consider 'a story of English country life' for every one prepared to consider an Australian one, while 'American editors took the trouble to translate and localise a lot of my stuff until I took the hint'. This was a severe handicap in an already crowded and highly competitive literary world. Lionel Lindsay made a similar point about English editors when he quoted one of them as saying that 'the British public is not a scrap interested in outside things'. ${ }^{28}$

During his stay in London Palmer 'saturated himself a good deal in the Fabian atmosphere in England ...', as he wrote to Nettie Higgins in $1909 .{ }^{29}$ In the years following the Boer War, when the two main political parties were poorly regarded, there was a growing middle-class interest in socialism of a Fabian kind which promised a more equitable society. The novelist, H.G. Wells, was among the provocative personalities drawn to the Fabian Society in these years. However, by 1906 Wells had lost patience with Fabian gentility and in a paper titled 'This Misery of Boots' he emphasised that socialism meant thoroughgoing social change. He became more explicit about Fabian shortcomings in 'The Faults of the Fabian' in which he lashed out at the 'old gang' of the society, calling them a 'drawing-room society', unresponsive to the possibilities which awaited socialists who were prepared to go out into the world and launch a more vigorous propagandist campaign. ${ }^{30}$

Where Palmer aligned himself in the challenges to the old gang is not certain, although on the evidence of later statements he would have found Wells persuasive on the need for more vigorous propaganda and a more activist approach to socialist organisation. In the middle of 1908 Palmer received a letter from his close friend in London, Stanley Cox, stating that 'The old gang don't quite understand the modern movement' with the implication that Palmer and himself were more modern in their approach. In a letter to Nettie Higgins in September 1909 Palmer wrote of the Fabians:

I used to find myself wondering how much some of its members felt the things they said or merely thought them, for when the 
creative work was to be done it was always the more militant section that bore the brunt of it .... You know some of the more theorizing type of Socialists are more interested in the little elaborations and details rather than the attainment of the practical reality. ${ }^{31}$

Vance Palmer returned to Australia via Finland, Russia, Siberia and Japan towards the end of 1907. When in Russia he tried to visit Tolstoy, but was turned back by a storm. On his return, he spent a year as assistant master in English at Clayfield Grammar School in Brisbane.

Early in 1909 a note appeared in the Socialist saying that Palmer had been in Melbourne for 'some weeks' and that 'comrade Palmer' had come from the Brisbane Headquarters of the Social-Democratic Vanguard of Queensland. It was announced that: ' $\mathrm{He}$ is in love with the Socialist Party and its agencies, and doubts if the Englishspeaking world holds a more energetic and enthusiastic combination. The Bijou meetings particularly have appealed to him. ${ }^{\mathbf{3} 2}$ Evidently, Palmer was making the most of his recent experiences overseas, for he was hardly entitled to speak of socialism in the English speaking world on the basis of his contacts with the Fabian Society. Nevertheless, his comments appear to have gratified the locals.

On his trip to Melbourne Palmer contacted Nettie Higgins and evidently made himself known in socialist circles in Melbourne. It is not clear whether this was his first meeting with Nettie, whom he may have seen even earlier, perhaps on a visit to Melbourne in 1907. Nettie Higgins, niece of Henry Bournes Higgins and an old scholar of the Presbyterian Ladies College, was completing her M.A. in 1909. Since 1907 she had corresponded with Bernard O'Dowd on topics which included the nature of socialism and the role of literature in society. Palmer would have known of O'Dowd as an established poet with a keen interest in the Victorian Socialist Party who regularly contributed to its magazine the Socialist. It is probable that Nettie introduced the two men. Certainly, she invited O'Dowd and Palmer to accompany her to a service given by the Reverend Frederick Sinclaire, then minister of the Eastern Hill Unitarian Church, and of whom more later.

After his visit to Melbourne, Palmer returned to Brisbane and towards the end of 1909 took a tutoring position at Abbieglassie station in Northwest Queensland. It was during this same period that Louis Esson was moving, metaphorically, away from the world represented by Fasoli's and into the world of the bush, which had 


\section{Dream and Disillusion}

become a local symbol for his new cultural phase. It was also in Igog that C.E.W. Bean, then a young reporter for the Sydney Morning Herald, was asked to write a series of articles on the wool industry. In his preface to the book which recorded his impressions, On the Wool Track, Bean wrote of the depression he felt at being assigned such an uninspiring task, until he hit upon an exciting approach to his topic. Describing the reactions of the young man he then was, Bean later wrote: 'And then it flashed upon him that the most important product of the wool industry for Australia was men: it was responsible for creating some of the outstanding national types.' ${ }^{34}$

Soon after he had settled in at Abbieglassie station Palmer wrote a letter to Nettie Higgins in which he stated his views on socialism. He alluded to one of her letters which declared that love was more likely to achieve socialism than the spirit of antagonism implied by the term 'class war'. Palmer answered that love implied a preference for some goals above others and declared that in his own experience class-war meetings had concentrated more on desired goals than generating hatred. He added that while he could understand that Nettie preferred to think of socialism in terms of 'love' and 'reason', he wanted to emphasise that 'the sense of grouping together to fight a very real and visible evil seems to satisfy a spiritual necessity in man, and notwithstanding all its distortions and exaggerations of expression it seems to me to be something very fine and holy'. In the same letter Palmer wrote that reason 'isn't the motive power of the world. And so', he declared, 'I pin my faith in the growing consciousness of the masses that Socialism will be in their immediate interest and to the permanent interest of all men'. ${ }^{35}$

In making these observations about 'motive force', Palmer was groping towards an understanding of how human societies changed. His picture is not a clear one, but he stressed that certain groups within society were becoming more conscious of the forces which oppressed them and more importantly, they were becoming more aware of the sort of world they wanted to live in. Palmer did not explain this discovery of new energies and new understanding in the 'masses' as primarily economic, but as the expression of some deeper urge towards spiritual self-realisation. While this explanation could be used to explain the great drama of human history, it also had some power to explain the forces which moved individuals. When Palmer fought the 'moral priggishness' within him he was 


\section{Vance Palmer}

attacking something which corresponded to the 'real and visible evil' he alluded to in the wider society. He saw redemption partly as a heightened sympathy for the efforts of those, particularly those among the 'masses', who sought means for spiritual growth. This was a simple enough way of looking at the world, but it emphasised what Palmer considered was morally valuable and authentic in human nature. This view of events persuaded Palmer that he should turn away from his middle-class origins and mould a new character, a new range of sympathies suited to the world which he believed was then coming into being.

In a letter which may have been a reply to Palmer's account of his socialist beliefs, Nettie Higgins asked how he could be a socialist in Melbourne. The question disoriented Palmer a little. 'I don't know whether you are laughing at me or not', he replied, but 'I feel more at home in the atmosphere of the Victorian Socialist Party than in the atmosphere of the Fabians'. He was encouraged by the fact that he did not have to dress a part when going to a meeting of the Victorian Socialist Party and for all the limitations of his fellow socialists he was convinced of the sincerity of their emotion. Palmer answered three charges which it appears Nettie levelled against Melbourne socialists, namely that they were Pharisaical, narrow and ignorant. He declared:

They are Pharisaical! (We are all Pharisees whether of the ninety or the nine.) Ignorant! Perhaps in some ways. Narrow! Yes. And yet in their meetings with all the bandying of catchwords and the singing of the Red Flag, I had a sense that their emotion was real and it helped me to believe in the reality of mine.

Palmer's reply was consistent with the argument that he wanted to understand the forces which moved working men and learn to respond to them. In a further comment to Nettie he declared that Melbourne socialists were 'largely working men, with the limitations that implies in our Society but I don't think they are quite as noticeable as the limitations of Culture . . . ${ }^{36}$

This statement is consistent with Palmer's preference for 'ardent nationalists' above 'cultivated writers' and restates his disenchantment with the literary strivings of his family, particularly his father who considered himself above the locals. While Henry Palmer evidently dismissed those around him as riff-raff, his son was very careful to see good in the working man, even to the extent of under- 


\section{Dream and Disillusion}

estimating the benefits of his own background and congratulating the working man on virtues he may not have possessed and perhaps could not have developed in the conditions in which he lived. This was more socialism as a cure for priggishness than socialism as a remedy for economic and social conditions which afflicted the poor.

While Palmer tried to persuade Nettie Higgins to his point of view by direct argument, he also slipped in some gentle mockery of the world Nettie shared with Bernard O'Dowd. When he saw a photograph of a recent river regatta in the Australasian, Palmer declared that he had looked 'among the crowd of cheerfully urbane faces for yourself and Mr O'Dowd', for such a setting with its 'well-dressed dowagers', its 'suggestion of flannels that mustn't be dirtied' and its 'atmosphere of very refined open-air' was precisely the kind of setting which Nettie had evidently portrayed as a world familiar to O'Dowd. ${ }^{37}$ It would not be too far-fetched to suspect Palmer of jealousy at the thought of an established poet having the good fortune of knowing Nettie Higgins well. In addition, Palmer's comments may have been intended to probe the nature of Nettie's commitment to literature. As the democrat remote from the world of elegant living he probably felt in a position to charge her with affectation and suggest, gently, that her interest in literature might have involved an unworthy pursuit of mere cultivation and elegant company.

Palmer's letters from Abbieglassie also provide glimpses of his life among station people. They, it appears, regarded him with scepticism. They looked with:

distrust if not with contempt on all my pet vanities, my literary ambitions and my attempts at culture but treat me with respect for qualities that I had forgotten - a good seat in the saddle when taking a stiff log, a discreditable knowledge of racing . . . 38

Palmer felt particular pride in the qualities which enabled him to find a place among station people, the more so perhaps as he realised how alien station life would have been to his father. Yet for all his talk about the limitations of culture it was important for Palmer to report back to Nettie Higgins on how the people at Abbieglassie had received him.

While he was at Abbieglassie Palmer planned a second and longer stay in London. In his autobiographical reflections he declared: 'My loyalties were fixed: I had no intention of making a home in London'. ${ }^{39}$ At the time, Palmer had informed Nettie 


\section{Vance Palmer}

Higgins that he might well stay in London for ten years, that is until 1920 or so. He knew that he could return to Australia whenever he wanted to "but that would be only philandering with life after all, and my immediate future is here ... and something wickedly reminds me that $I$ imperilled any chance of its realization by going back home three years or so ago'. ${ }^{40}$ Almost a year later Nettie wrote to her mother that 'Fleet Street claims him [Vance] for some years yet and if I marry him in two years, it means living in London for some time ...' ' ${ }^{41}$ The decision to return to London reflected Palmer's new determination to establish himself as a writer. During his five years in Australia from I 906 he had done almost no writing and there is no evidence that his views on literature were very much further developed than they had been in 1905. However, his next five years in London were vital ones. In these years he broadened and deepened his understanding of key terms like national character and national consciousness and their relevance to socialism and to the role of the writer in a modern industrial society. Indeed, Palmer owed more to ideas derived from his London experience in the years 1910-15 than his autobiographical essays convey and more than any critic has appreciated. 


\section{3 \\ Vance Palmer in London}

Palmer arrived in London for the second time in 1910. In his account of the years 19I0-14 the historian George Dangerfield wrote of that year as a 'landmark in English history' for in 1910 'fires long smouldering in the English spirit suddenly flared up, so that by the end of 1913 Liberal England was reduced to ashes'. ${ }^{1}$ In The Revolutionary Movement in Britain 1900-21, Walter Kendall described the 'mass strike wave of I910 to I9I4' as 'unique in British history'. 'A wild, elemental, pent-up force seemed suddenly let loose, disregarding precedents and agreements, impatient of compromise, shaking the old complacent trade unionism by the ears ....' Palmer had moved from the quiet of Abbieglassie station into the middle of this turbulent society.

It was a period in which the Parliamentary Labour Party seemed unable to answer the needs of rebellious trade unionists, many of whom disparaged the Labour Party as a force for change in society. Encouraged by an enormous growth of membership in the period Igoo-14, many trade unionists turned their attention to extraParliamentary activities. In his section on 'The Workers Rebellion' Dangerfield wrote of the 'wildly plutocratic' nature of this period, of the 'intolerable bureaucracy' which emerged from the plans of the Labour Party and the Fabian Society, and of the forces which turned English trade unions into 'an outstanding symbol of rebellious energy'. ${ }^{3}$ In the period January to December Ig I I over 900,000 workers were involved in stoppages, 300,000 more than in any previous year. In the same year, trade union membership had increased by 600,000 . In 1912 there were 857 disputes involving over $1,200,000$ workers. ${ }^{4}$ Accumulated evidence of this kind prompted Dangerfield to ask a deeper question:

And as the great Labour Unrest of I9ro-I4 unfolds itself, might one not see it as a profoundly unconscious assault upon respectability, a vital revolution in the world of the soul ?5

Certainly, Palmer felt the events of his second period in London could not be explained solely in economic terms. Although he was 


\section{Vance Palmer in London}

still attracted to socialist ideals, he grew disappointed by the failure of Fabian Socialism to come to terms with pre-war society. Palmer felt that the turbulence of the time was only the expression of a deeper spiritual malaise which would only be cured by the creation of a more humane society. So he felt that above all, socialists should respect the creativity and dignity of each individual. It is evident from a letter to Nettie, written early in 1912 , that conventional socialist responses to events often exasperated him:

The state of things has been unbearable lately: a million men out on strike and the ILP [Independent Labour Party] dumb and inactive. The Fabian society was worse for it was talking about equality under Rameses II, - or something like that. I wonder do they know how utterly they have lost their grip on reality. ${ }^{6}$

In an earlier letter to Nettie, Palmer had expressed dissatisfaction with recent legislation designed to improve working-class conditions. Nettie had shown enthusiasm for socialist legislation in Germany, but Vance was sceptical, wondering whether it was socialistic or merely bureaucratic. The bureaucratic legislation he had seen in England had aroused his grave mistrust. He protested: 'Its mere irony to call it [this legislation] socialistic when the ordinary man doesn't get anything approaching compensation for the liberty he gives up ....' Every time he came away from the Fabian Society, he added, it was 'with a sense of disillusionment'.?

Palmer's increasing disappointment with Fabianism coincided with a growing interest in the New Age and its principles of social reconstruction. After 1912 these principles were systematised and became known as guild socialism. Worker-control of industry and the long-term organisation of all major industries into some twentytwo self-managing guilds were key proposals in guild socialist thinking. However, in much guild socialist writing, the term 'guild' was used to evoke the image of a brotherhood of craftsmen who were able to bring artistic qualities to necessary everyday tasks. The craftsman in this image was a figure of considerable appeal. He was pictured as a man who was able to devote care, time and love to his work, and as a man who combined both robust commonsense and artistic sensitivity. Most guild socialists were pessimistic about the chances of actually restoring the craftsman as a key figure in modern industrial society, but they hoped that at least worker co-management of industry would give the modern 


\section{Dream and Disillusion}

workman a greater degree of involvement in his particular industry, thereby restoring a feeling of responsibility and dignity. ${ }^{8}$

By writing of the craftsman as they did, guild socialists also hoped to dramatise the social polarisation of modern England. They pictured a cultivated class remote from the ordinary people and a servile working class, deprived both of an involvement in creative work and of the essentials for a healthy life. Guild socialists argued that this polarisation had bad consequences for the nation. They maintained that modern man was in danger of becoming trivialised, especially as they believed that the traditional sources of 'folk culture' were increasingly threatened by the conditions of modern society.

Behind the more explicit guild socialist proposals for social reconstruction lay the rather more vague ideal of their finer society. They pictured a world of small, tractable communities in which men could work creatively, caring for each other and the conditions in which they lived. The concern to return to a world of a smaller, more human scale was also expressed in the guild socialist's dissatisfaction with cosmopolitanism and his desire to maintain national traditions and foster the development of a national character. In some respects Palmer had held similar views to guild socialists before rglo. However, his contact with the New Age and Orage was decisive in clarifying his ideas.

Palmer's short story 'Rough Faring' was published in the New Age in July 1911 , and shortly afterwards he became acquainted personally with the journal's editor, A.R. Orage. ${ }^{9} \mathrm{He}$ also began to attend some of the meetings in a café opposite the New Age office, where Orage and his contributors gathered each week to hammer out their ideas. Palmer found Orage an inspiring figure and confessed to Nettie that he would 'rather write well for him than for anyone else for his criticisms are so impartial and uninfluenced by personal considerations'. ${ }^{10}$

In many of his articles for the New Age, Orage examined the possibility of complementary relationships between nationalism, national character and socialism. He was disturbed at the relatively slow progress socialist ideas had made in England, but suggested that this could be because socialism was connected in the popular imagination with something alien to the English national character. ${ }^{11}$ He therefore believed that old socialist traditions would have to be forgotten, particularly those which linked socialism with subversive off-shoots from European movements. Orage envisaged 
new ways of expressing socialist values which would bring the 'movement closely into touch with the common public and the national life'. ${ }^{12}$ Moreover, he felt that the English nation was not merely a physical and geographical unity, but a 'sentient and conscious unity as well'. Such signs augured the dawn of 'a conscious nation'. Orage went on to support 'national character' as an approved term among socialists, rather than 'cosmopolitanism' which he associated with loss of identity and restlessness.

Orage wanted English socialists to reconcile their socialist principles with the traditions of English life rather than to pursue superficially more alluring European versions of socialism. $\mathrm{He}$ believed that remoteness from national traditions impoverished the imagination of the more cultivated classes and limited the potential for a richer national life among the common people. This was an appeal to become less European and more English; less sophisticated and more in touch with the life and traditions of the common people in England; less cosmopolitan and more concerned with national character.

Ideas like Orage's also had implications for literature. This is evident in a New Age article of 1910 titled, 'The Drawing Room Table in Literature', which deplored the bad effects of the drawingroom atmosphere. The writer argued that the gentility and politeness of the drawing-room bred an artificiality and remoteness from the lives of ordinary people which restricted the imagination and produced false cultural standards:

standards in which the root and brute facts of existence are ignored, and feeble ideals are cultivated of an intellectual and spiritual life unfed and unnourished from the breasts of the common humanity. The only road back to sanity is through the remingling of classes and masses and the large readaption of the modes of life, thought, and speech still current among the latter. ${ }^{13}$

This article, like others in the New Age, was a direct expression of that revolt from 'Literature with a capital L' which Arthur Phillips felt distinguished the Australian writer from his European counterpart.

It is worth emphasising that the New Age article argued that the more cultivated classes should renounce their upper-middle-class values and develop a closer contact with 'the people' thus becoming more human, and more creative. They would then also become more 'English', for the writer located the best qualities in the national 


\section{Dream and Disillusion}

character among the poorer elements of society. He did not consider the national character of the true Englishman to be middle-class. A comment made by Maisie Ward indicates the depth of this disillusionment with middle-class values in pre-war England. She states that Shaw, Chesterton, Wells and Belloc all agreed that the upper and middle classes of England had to be 'reminded, if need were by a series of earthquakes, that they were living in an unreal world. They had forgotten the human race to which they belonged'. ${ }^{14}$

The New Age had warned that cosmopolitanism, sophistication and dedicated cultivation betrayed the ideal of a finer national life which was richer, more vital, more just and more democratic. However, there were other threats. In a series of articles in the New Age from May 1908, Hilaire Belloc warned of the dangers of the 'servile state'. ${ }^{15}$ His arguments were endorsed by distributivists and guild socialists who attacked Fabian collectivism and were also to have an influence on Vance Palmer. Broadly, Belloc maintained that in modern industrial society, the employer was becoming increasingly responsible for the comfort, security and permanence of employment of the employee. If this development continued the employee would become so dependent on the employer that the relationship would amount to effective ownership. Belloc referred to this condition as 'The Servile State'. He argued that the encroaching power of the employer could be stemmed by the more equal spread of wealth and property and the establishment of small land-owners; a remedy based on the Encyclical Rerum Novarum. ${ }^{16}$

Another strand of anti-Fabian thinking also appeared in the $\mathcal{N}$ ew Age in 1908. W.R. Titterton, who later became a close friend of Palmer's, wrote articles against the dryness of Fabian socialism, declaring that the statistical approach to society was death to the artistic spirit: ${ }^{17}$ Through his commentaries on the dance and the music hall, Titterton argued for a socialism which was emotionally warmer and more sensual than he felt the Fabians would allow. Isadora Duncan became one of his enthusiasms and he commended her spirit in the New Age: 'If you are for blue-books', he wrote, 'I am against you .... Isadora showed me the thing I desired. This is my Socialism .... I fling wide to the winds my banner of the dancer .... '18

In Titterton, love of the dance and the music hall was combined with a love of merry England, its guilds, its rural beauty and its Catholicism. Appropriately, Titterton later became a Catholic 
and also a distributivist and follower of G.K. Chesterton. While the views presented in the $\mathcal{N} e w$ Age by Belloc and Titterton may seem very different, the two men were united in the belief that Fabian socialism did not take sufficient account of the human demands of dignity, responsibility, freedom and joy. Belloc stressed the dangers of a society in which these qualities were denied and Titterton the pleasure that could result from their fulfilment.

The New Age with its ideas from men like Orage, Belloc and Titterton, excited Palmer. He welcomed its particular form of socialism which emphasised the importance of national traditions in the development of a guild socialist society. However, it also disturbed him with its accounts of the power of the modern state to destroy the spirit of community and made him apprehensive for the future of Australia. Palmer believed that Australia, as a country with an insecure sense of history and little traditional folk culture, would be especially vulnerable to the problems of urbanisation and industrialisation, to the growing power of the modern state and to the appeal of cheap popular culture. One must appreciate Palmer's convictions about the cultural disadvantages of Australia in order to understand his later emphasis on national character, national consciousness, the common man, the qualities of endurance and austerity, the virtues of craftsmanship and the spirit of community. Palmer's experiences in London in the years $1910-15$ and his contact with guild socialism had stressed the importance of these qualities in any society which attempted to resist the trivialising effects of modernity. Palmer stressed these qualities in Australia, not because they reflected the realities of Australian society, but because he considered them vitally important attributes which were too little appreciated by most Australians. They were the qualities he wanted in Australia, not necessarily the ones he found.

Although Palmer was attracted by the emphasis on national character in much guild socialist writing, the concern for English traditions expressed in the New Age and by Titterton and his friends also placed him in a somewhat paradoxical situation. While he approved of these ideas, the stress placed on English traditions made him feel more alien in London and more nostalgic for his Australian background. In certain circumstances English insularity could become rather oppressive. Soon after his arrival in London, Titterton introduced Palmer to a weekly dining club which had been formed by Cecil Chesterton. Palmer wrote ruefully of this experience to Nettie: 


\section{Dream and Disillusion}

I don't usually obtrude the fact [that he is Australian], because English people seemed to think you've committed a gaucherie if you let it out .... It would be funny if it wasn't amazing at times. [In the same club he reacted to a slighting reference to Australia.] I flared up a little and there was a chorus of surprise from a few that I should be what I am. Then they turned to another topic as if it were indiscreet of me to be there. ${ }^{19}$

Palmer was also irritated by a remark made by G.K. Chesterton. Chesterton had pointed out that while Australians talked of the power and mystery exercised on their imagination by the great open spaces, what really appealed to them was The Mystery of a Hansom Cab. American writing, Chesterton maintained, told a similar story and confirmed the belief 'that Western civilisation had no permanent foothold there'. ${ }^{20}$ Assumptions of this kind about colonial bad taste annoyed Palmer although he continued to hope that Australian literature would be known for its strengths rather than its weaknesses. The guild socialist emphasis on English virtues also inspired him with the belief that Australia too might achieve a robust national culture.

English superiority continued to annoy and disturb Palmer. After a further irritating encounter with English patronage at a London club he wrote to Nettie of his patriotic feelings towards Australia:

Have I ever given you a glimmering, dear of some passionate sort of patriotism that is always surging about at white-heat in whatever depths I have? I try to screen it generally because there is no way of expressing it that doesn't have a cheap aspect nowadays, but its there all the time and it leaps out unexpectedly on occasions. I believe it was the first consciousness I ever had of a soul for its been there as long as I remember and they used to chaff me about it when I was a small kiddy. It has a different flavour now and is mixed up with something I saw back there in the bush a year ago - [Abbieglassie] just a few trees and plains and the lives of a handful of men. And $I$ feel if $I$ do anything worthwhile it will be because that vision shines through .... ${ }^{21}$

Palmer pictured himself, with some reticence, as a man whose depth of character, passion, understanding and spiritual integrity were thwarted by his inability to find a way of expressing his feelings. The letter to Nettie suggests the development of an inner life, circumscribed by a hostile environment. The statement is a declaration of Palmer's right to be patriotic and perhaps a rehearsal of his role as an 'ardent' nationalist, not necessarily a simple under- 


\section{Vance Palmer in London}

taking in the face of socialist arguments which often placed internationalism above the divisive claims of national pride. For Palmer, it was a relief to find a journal like the $\mathcal{N e w}$ Age which did not declare that patriotism and socialism were incompatible. Moreover, in a society where both trade unionists and suffragettes had protested at oppression and demanded their rights, Palmer could feel, perhaps, that he too had a right to claim patriotic feelings when they arose from a desire to express his better self more fully.

Palmer was not alone in his frustration with the English and in finding reassuring qualities in his own people. Similar responses were evident in Ezra Pound, a regular contributor to the New Age. In articles to the New Age Pound wrote of his impatience with English social conventions, particularly the cautious approach to outsiders: 'A new acquaintance is an experiment, a new friend a peril.' He described clubs and genteel afternoon teas as the institutionalised expression of centuries of polite and evasive conduct, and dismissed this as 'a rather anaemic sort of life'. Pound looked with fondness and relief to his native America where his fellow countryman was 'constantly rushing into intimacies, in the hope that each new person may be the person for whom he is looking...' and was thankful that: 'City life has not yet wholly obliterated these customs among us. ${ }^{22} \mathrm{He}$ also fitted this account of American energy and English enervation into a wider picture where America was described as 'a province without a centre' whereas London was 'a vortex drawing strength from the peripheries' ${ }^{23}$

In the middle of 1912 Palmer returned to Australia where he stayed until July $1913 .{ }^{24}$ His immediate motive for the visit seems to have been a meeting with Nettie's parents after his engagement to her in May IgI I. However, the shortness of the visit suggests that Palmer had no real intention of settling down in Australia at this stage, believing perhaps, as he had done previously, that he could best pursue his career in London.

Palmer was discouraged by what he found in Australia. He wrote to Nettie:

Hardly anyone here understands anything about the labour movement in England: they think you're merely being cynical and disillusioned when you state a few of the base facts. It seems sometimes as if Australia were just far enough away from England to copy her, instead of drawing lessons from her experience. ${ }^{25}$

Palmer indicated what some of these lessons were in three articles 


\section{Dream and Disillusion}

which he wrote for the Socialist in $1913 .{ }^{26} \mathrm{He}$ pointed to the ineffectuality of the Labor Party and the need for a vigorous trade union movement aiming for worker-control of industry and, ultimately, the guild organisation of society. For Palmer, ignorance of the British labour movement and its lessons increased the danger of Australia becoming a 'servile state'.

His first article opened with the observation that a recent railway strike in England had begun as a protest against the dismissal of a mechanic. The man had been convicted of drunkenness in his own time and had consequently had both his rank and pay reduced. Palmer declared that the strike was provoked by a sense of moral outrage that a railway company could encroach upon the liberty of the mechanic as a private citizen. The incident provided an example of that erosion of liberty which guild socialists and distributivists had feared would develop in modern capitalist society. It was also an apt example of the movement towards the servile state. Palmer defined this as:

a State in which the capitalist would have security against strikes, sabotage, and all risks arising out of Labor troubles; the workers would have security against unemployment and insufficiency - at the cost of their liberty.

He considered the dangers of the servile state just as real to Australia as they were in England, and perhaps even more so, for Australian public opinion, he believed, was not as well informed by a sense of history and was too ready to accept any change as progress. Moreover, he believed that the working class had won their concessions in Australia with relative ease, and as a result were more alert to material improvement than the preservation of liberty. Not that Palmer considered material improvement unimportant, rather he felt that it could be won at too high a price. He concluded:

It is easy to foresee the progress of a State, uninspired by ideas, unchecked by independent criticism, that so blindly forges, link by link, the chains that will presently be too heavy to throw off ....

In the last of his three articles Palmer looked at the decline of the Fabian Society in England and suggested a policy for Australian industry along guild socialist lines. He noted that in 1906 and 1907 the Fabian Society and the policies of collectivism had been highly 


\section{Vance Palmer in London}

praised. However, since that time there had been a steady erosion of confidence in the Fabians and by 1913 the spirit and effect of collectivism were under heavy attack. In explaining this change of attitude, Palmer emphasised that the Fabians had experienced a failure of will in the face of real opposition, and suggested that the Fabians were more inclined to talk at their opposition than to challenge them. Palmer maintained that many Fabians were not really concerned with democracy and the ideas related to it, for 'they were not mainly inspired by ideas of justice'. He also alleged that Fabians wanted more leisure for the working class so that they might: 'read Nietzche [sic] ... or wander about the art-galleries; in short, in order that they might become semi-literary, semi-artistic, middle-class people like themselves. ${ }^{27}$

In contrast, Palmer suggested that guild socialism provided the basis for a just society. He sketched the sort of changes which would be necessary:

Our unionism must be recreated. It must ... divide itself into industries ... Each industry must study itself, its order, details and management, so that (like the postal service of France ...) it may be competent to run itself in co-operation with the State... . ${ }^{28}$

These articles and Palmer's letters to Nettie emphasise how the events of 1910-13 and the influence of the New Age sharpened several key attitudes in Palmer: a distrust of leaders of society; the politicians, the clergy, the press; anxiety at the growing power of the state; a belief that man was becoming a victim of the machine; respect for the broad humanity of the common man; the need for immediacy and experience and a belief that periods of great social stress could generate movements capable of establishing a new order of society.

The years spent in London also stimulated Palmer's literary ambitions. Much of his time was spent writing pot-boiling short stories which made their way into papers like the Sunday Chronicle or American magazines such as the Illustrated Sunday Magazine and the Bellman. Palmer was probably referring to stories of this type when he mentioned in a letter to Nettie that he had written eightyone short stories during his first nine months in London. ${ }^{29}$ Titles of some of his Sunday Chronicle stories suggest their quality and readership: 'A Seaside Philander: Mr Jupp and the Lady with the Toy Pomeranian', 'Em'ly's Husband: Mr Opper Plays a Great Card', 


\section{Dream and Disillusion}

'The Man with the Spats', 'The Intervention of Uncle 'Arry', 'The Christmas Party which went all Wrong', 'A Change of Heart: Concerning the Deception of $\mathrm{Mr}$ Horace K. Priestly'.30 Palmer stories of a similar kind were published in the Illustrated Sunday Magazine for 1916. Two of the titles read: 'The Girl and the Gunboat' and 'The Marooning of Marryat'. Louis Esson noted that during this period Palmer had 'sketches on the London music-halls, his "Burglar and the Baby" being quite a popular success'.31 Later, in 1917 , Esson referred to the second of a four part story of Palmer's

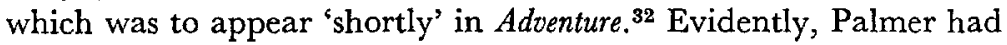
some successes as a pot-boiler, for early in 1914 he was able to tell Nettie that: 'The last few months since I came back [from Australia] have been very successful and I have not got much fear of the future now though of course we will have to live very plainly for a year or so'. ${ }^{33}$ As he wrote, Palmer also had the satisfaction of knowing that several of his better short stories had also appeared in recent numbers of the New Age. Five of these stories were later incorporated in The World of Men.

The World of Men was based largely on Palmer's memories of his experiences at Abbieglassie station. Since the stories all concern the working man and his daily life one might expect them to celebrate the working-class qualities Palmer considered so important. Palmer once listed these qualities as 'courage, generosity, sociability' describing them as 'all prodigal things that do not make for personal advancement'. At the time he also expressed his dissatisfaction with the middle-class values of 'thrift, sobriety, prudence, restraint'. ${ }^{34}$ Given Palmer's attitudes one might expect a robust, intimate and affectionate spirit to pervade The World of Men. In fact, the reader is in the company of a man who has opinions about his characters, rather than a sympathetic bond with them. He enters the accepting 'world of men' as the cosmopolitan observer and derives satisfaction from this tolerant, casual, yet hardworking life. It was a world which respected privacy on the understanding that each man was a free, independent, self-respecting individual; a foreigner to servility. But it was also a world where close emotional involvement was assiduously avoided.

This unwillingness to become involved is evident in the first story of Palmer's collection, which describes the arrival of the narrator together with a coach driver and two other travellers at an outback shanty which is occupied by a seedy hermit named Joe. The story is closely concerned with the character and presence of 


\section{Vance Palmer in London}

the hermit, but Palmer nevertheless makes little attempt to analyse the reasons for his behaviour. He drops the casual, almost unconcerned statement: 'Perhaps it was solitude that had twisted his mind and driven him into alliance with the kangaroo-dogs, snakes, and other inhuman things ... ' and the suggestion is allowed to pass. Later in the story, it is revealed that Joe married a black woman and had spent nearly twenty years in gaol on a series of convictions for cattle stealing. This information is also accepted without further analysis as if too much curiosity would imply moral censure. ${ }^{35}$

A similar attitude is also evident in another short story, 'The Long Road'. The story concerns a drover named Denison whose negligence had caused the death of his mate in a cattle rush. The other drovers recognised in Denison:

a man who had failed in the one thing in which it was important not to fail, one whom life had caught in a weak moment and defeated, and there was a detachment about their attitude as though they felt no sympathy or censure of theirs could affect the issue. ${ }^{36}$

The narrator shares this reluctance to intervene or question the course of events and only declares that 'Man's strange habit of accepting responsibilities ... is one of the puzzling facts of an incomprehensible world'.

The narrator shares a distrust of any further analysis which imitates the spirit of the drovers. Denison's failure, and the drovers' response to his failure are taken as the real data of experience, an expression of the basic realities of life. The drovers are presented as men who reveal primal truths about man. This can be seen as an example of the basic distinction between a fundamental and a derived self as made by Bergson who distinguished 'between a "fundamental self" which seems to be naturally there, and "a parasitic self", the product of education, "which continually encroaches upon the other" '.37 This duality also troubled Palmer.

Palmer's short stories suggest that the writer was a reserved man who respected honour and integrity in other men. He seems to be a man who was able to give warm endorsement to a cause, but was inclined to emotional caution in more immediate contacts with his fellow men. Palmer regretted this aspect of his character especially where it seemed to imply a withdrawn temperament which took to literature as a shelter from the world. This attitude 


\section{Dream and Disillusion}

is vigorously denied in 'Brede' where the narrator comments: 'Books are a poor substitute for companionship; they lose their salt when they are elevated to anything but a pleasant retreat from the flood of human intercourse'; a somewhat more cavalier attitude to literature than that which Palmer had expressed in 1905 in his article to Steele Rudd's Magazine or in his intense reading of Balzac before that date.

The picture of Palmer as a man of reasoned emotions is supported by a glimpse into the inner man which he revealed to Nettie in rgi3. He confessed:

You see I've never been able to give myself away very much ... and $I$ found the casual friendship of men deep and satisfying enough .... Out in the world I can swashbuckle with the rest but when I come where you are I feel utterly humble. You're bigger and better than me in every way and all your little ways are steeped in beauty. ${ }^{38}$

While Palmer believed that reserve was a necessary condition for respect, he could see that there was a fine line between reserve and an emotional inadequacy which reflected a lack of human depth.

Even so, the 'casual friendships' of the male world still attracted Palmer, although he was able to see depths in Nettie which could not be dismissed as the morbid intensity of a 'female' mind. Many of the admired qualities in The World of Men were readily assimilated to a guild socialist respect for the practical skills of the craftsman. Similarly, the guild belief that the skills of the artist should be turned towards the practical problems of the day was anticipated by Palmer's attraction to a people in whom he saw practical abilities combined with the qualities of honour, courage and responsibility. The pattern is even found in Palmer's affectionate portrait of the dog, Brede, with his democratic temperament shaping an artistic sensibility.

Palmer's next book, titled The Forerunners, also published in 1915 , reads as a verse tribute to the people who would make Australia a land of destiny. The aims of this work were outlined by Nettie in a letter to her brother, Esmonde. She declared that Vance wanted 'to write simply about a straightforward kind of life and his aims had been to write words and metres to represent that life - to communicate it to the gentle reader'. ${ }^{39}$. She emphasised that this aim represented a departure from the poetic style of Bernard O'Dowd:

These poems, written while Palmer was in London, indicate 


\section{Vance Palmer in London}

one source of his frustration in that city. He was surrounded, almost smothered, by the self-esteem of the English; the established conventions of their clubs; the pride in an English heritage; the casual mockery of foreigners. There was an enviable order and poise about the English which no young Australian could possess without disowning his origins. Moreover, Palmer could find no satisfactory poetic outlet for the patriotic feelings which burst through in occasional letters to Nettie Higgins. Although he was uncertain of his emotions and unclear in his vision of the coming Australia, Palmer wanted to pour out what emotions he had as a declaration of his faith. The Forerunners provides one indication of the various ideals which moved him at this time and also suggests his difficulties in finding an appropriate language and metre for his poetic sentiments.

The Forerunners is an uneasy combination of simple ballad forms and rather too ponderous emotion. The final stanza of the title poem suggests the spirit of the collection:

Sowers of fire, the dawns forerunners,

We seek the bivouacs of the young,

Our fealty pledged to unborn chieftains,

Our blood aflame with songs unsung. ${ }^{40}$

The pledges, 'bivouacs' and 'chieftains' of this stanza are not easily reconciled with straightforwardness and simplicity.

A constant theme of The Forerunners was the need for the people to celebrate the beauty of their land in songs and poetry. Palmer evokes a folk gaiety which suggests a rather envious love for the merry England, energy and enthusiasm so beloved by Titterton and G.K. Chesterton. ${ }^{41}$ In 'The Harbinger' Palmer presents a desolate image of rural Australia in language which suggests rural England:

All dumb and joyless reapers move

Through fields they have not learned to love,

About the barns no voices ring,

No songs are raised at harvesting.

The verse evokes a world without folk culture to express a bond with the soil, a love of the seasons or a joy in labour.

The 'merry England' associations of 'The Harbinger' can also be found in 'The Awakening'. In this poem the poet anticipates the emergence of a new culture in which people will assert themselves 


\section{Dream and Disillusion}

against the men of commerce and property whose spirit dominated the land. The poet celebrates this new world in language permeated by religious imagery and the traditional associations of the newly tilled soil:

But their alien creed shall perish, and we shall come into our own,

The hope of our fathers shall guide our feet, the Cross shall shine on our path,

And the red flame, the holy flame, shall be lit on the sacred hearth.

The inflated style reflects Palmer's sense of history. He calls for broad changes in much the same spirit as O'Dowd, which suggests that Palmer did not object so much to the scale in which O'Dowd presented his vision of the past and the future, as to O'Dowd's ornate language. In 'The Harbinger' Palmer pictured a new age of idealism sweeping the commercial spirit out of positions of power and influence. Similarly, O'Dowd saw the battle with commercialism as crucial to an understanding of the development of man across the centuries. Thus, as a young man Palmer responded readily to vast generalisations about the past which bore little relation to Australia's historical development. His interest in Australian history was a later concern.

Palmer's attitude to the past in the years before World War I was similar to Esson's in the same period. They both looked to the past for consolation, hoping that the broad movement of history would bestow an auspicious future upon man in Australia. They were often awed by the past, troubled by their own shortcomings and distrustful of modernity. However, while they spoke of a great national challenge, they wondered from which quarter it would arise, and what form it would take.

The Forerunners confirms Palmer's indecision in this period, for his poetry reflects a variety of influences and styles. There is 'merry England' in Australia: warm, cosy, pipe-smoking, carousing, soil loving; a world alive with songs and poetry. There is also heroic indignation:

And hate burns through me as I ride

To the black shanty where to-night

The bravest lad on Barwon side

Is hanging in the cold moonlight.

Indeed, there is a good deal of melodramatic death and some 


\section{Vance Palmer in London}

uncertain evocation of an alien landscape hostile to man. But there are also jaunty Septembers alive with youth, hope and vitality. In short, The Forerunners does not support the view of Palmer pursuing the steady goal of a national literature from young manhood into old age which so often appears in the critical accounts of his career.

In The Forerunners Palmer revealed a disappointment with life in Australia, a country isolated from the rest of the world and unresponsive to the challenges of the future. The Poet's challenge was to awaken his people to the promise of the future. He was the fire-bringer and the dawn's forerunner. The dominant mood was one of anticipation. This emphasis diminished the importance of capturing local rhythms and of exploring more closely the details of Australian life; qualities which Palmer displayed in later work, notably The Passage.

The acceptance of the local community in The Passage was part of a long process of reconciliation with Australia which had been speeded along during the years I910-15. Then, between I9I5 and I9r8, Palmer went further than he had done previously in examining and defining what he termed the 'emerging national culture' in Australia. This 'national culture' was related closely to his hopes for a new sense of community in Australia which would value the common man, nature, reality, character, craftsmanship and work; a constellation of requirements and values which Palmer came to describe as among the authentically 'Australian' qualities. How these qualities, many of which Palmer derived from his English experience, became 'Australian' is examined in Chapter 6.

Palmer emerges from the years 1910-15 as a man who felt that his truer self had not found expression. He felt unfinished, spiritually incomplete. He wrote as a man conscious of a barrier between himself and other people and, more particularly, he felt that his truer self was deprived of some of the profounder emotions of patriotism. Palmer was unable to feel that England, with all its historical associations, was his own country. Yet when he looked to Australia, he felt that it was not yet a nation; that the Australian people did not exist in the same manner as the British and that the name 'Australia' had few of the cultural associations, and traditions which attached to 'England'.

At a time when Palmer's 'truer self' was in conflict with his 'priggish', 'bourgeois' or 'parasitic' self, so too were there forces within English society, particularly in the years $1910-15$, in conflict 


\section{Dream and Disillusion}

with the framework of the old society. In the context of the wider struggle, Palmer's attempts to realise his truer self and discover a finer patriotism assumed some historical significance for him. He felt that he was not merely patriotic in a 'cheap' sense, but that his own patriotic feelings were identical with the urge towards self-realisation which he believed animated the labour movement. Moreover, by this process Palmer linked his own endeavours to become a finer Australian with a broader movement of historical forces which he hoped would draw the new community of the future out of the shell of an older doomed society. 


\section{4}

\section{Frank Wilmot in Pursuit of Poetry}

On several occasions before World War I Esson and Palmer expressed the hope that glory had not disappeared from the earth. Palmer imagined his ideal Australia as 'a glorious nation', and described the writer's mission in building the new Australia as 'the most glorious task ever conceived'.1 'Glory', the dictionary tells us means 'renown: honour: the occasion of praise: an object of supreme pride: excellency: splendour: ... the presence of God ... '.$^{2}$ Esson matched Palmer's splendid vision when he suggested that the Australian statement would be 'luxuriant, full of colour and melody, with space and freedom in it, joyous, a thing of beauty'. ${ }^{3}$ Both statements suggest an esteemed nation whose citizens were envied for the challenges and splendid achievements which faced them; a nation which offered room for growth and development.

Esson and Palmer knew that the Australian reality fell short of this vision. Esson felt that Australia had been settled by an unimaginative people in a mediocre phase of human history. He saw both the English character and capitalist society as interacting forces which demeaned man and diminished his creative imagination. At this level of Esson's thought, the only bridge to the future, and a frail one at that, was the prospect of a new type of character, the true Australian, recovering his human powers within the wider freedoms of a socialist society. Unfortunately, the means to Esson's desired end remained unclear. As young men Esson and Palmer protested against a 'modernity' which they felt produced trivial deeds and mean motives unsuited to great literary themes.

In prose and poetry Frank Wilmot (Furnley Maurice) explored themes which also concerned Esson and Palmer. ${ }^{4}$ Like them he wrote of the Australian promise, but also of the deficiencies of the modern world and of the gap between literary achievement and expectation. 


\section{Dream and Disillusion}

Frank Wilmot was born in Melbourne in $188 \mathrm{I}$ and lived there until his death in 1942. He was the second oldest of five children. His father, Henry William Wilmot, had studied for the ministry of the Congregational Church, but he came to doubt his calling and finally took a job in the small family ironmongery works, until the depression of the early 1890 os forced him to find other employment. He eventually became a shopkeeper in North Fitzroy, where he sold hardware, fancy goods and school stationery.

Henry Wilmot was not suited to his job as shopkeeper, for he had no aptitude for making money; a limitation which required skilful budgeting from Wilmot's mother. While he made a poor fist of balancing books, Henry Wilmot enjoyed reading them. $\mathrm{He}$ was particularly drawn to the writings of William Morris and believed that a return to craftsmanship was essential to social reform. He put these beliefs into practice by working at handcrafts, cabinet-making, printing and black-and-white drawing. Henry Wilmot also became secretary to Victoria's first socialist group, the Social Democratic Federation, and served on the executive of the later Socialist League. At one point he had hopes of standing for Parliament as a Labor member. His preparation of 'Vote for Wilmot' notices was well under way when he discovered to his profound disappointment that he had not been pre-selected. Soon afterwards he suffered a stroke and his health then declined until his death in 1907.5

The family background ensured that Frank Wilmot grew up among books. As a boy he probably read the popular adventure stories of the day known as 'penny dreadfuls'. There were also penny pictorials like Big Budget and Comic Cuts which were the precursors of latter-day comics. More substantial reading was available from a penny library which one of Wilmot's brothers ran in a corner of the family shop. Among other books, this library stocked the Waverley novels in a sixpenny paperback edition. ${ }^{6}$

Books remained important for Frank Wilmot. He left the North Fitzroy State School at thirteen, when the family finances were unsteady and the depression a recent memory, to take a job in Cole's Book Arcade. Here he was exposed to views on the advance of human society which bore some resemblance to those of his father. The self-educated proprietor of the Book Arcade, E.W. Cole, proclaimed the value of books in promoting the brotherhood of man and the advance of the human species. Cole also had a shrewd understanding of the commercial value of novelties and gimmicks. 


\section{Frank Wilmot in Pursuit of Poetry}

Two mechanical men displaying revolving texts on the importance of literature stood at the entrance to the arcades. Inside, a small band competed for attention with an aviary, a cage of monkeys and verses on the walls declaring 'books to be the true means of bringing about the Parliament of Man and the Federation of the World'. All in all, the arcade was as much a diverse and crowded place of amusement as a bookshop.?

Wilmot later came into contact with a less commercially astute enterprise concerned with the radical transformation of human society, when he became a contributor to the socialist magazine Tocsin. During 1898 he published a number of poems in the journal including 'The Song of Socialism', 'The Fatman's Song', and 'Lead On'. ${ }^{8}$ As a Tocsin contributor Wilmot came under the editorial eye of Bernard O'Dowd who encouraged the young poet; indeed, in Igog O'Dowd was able to boast to Nettie Higgins that he had 'suckled him practically'. ${ }^{9}$ Through O'Dowd and Tocsin Wilmot was brought into closer contact with the main currents of socialist thinking in Melbourne at the time.

At the age of twenty-one, with eight years experience in the Book Arcade behind him, Wilmot and a friend produced a small magazine titled Microbe: A Journal Published in the Interests of Amateur Writers. The journal, described by Wilmot as one product of a suburb better known for 'muddy flats, rusty tins, [and] defunct cats ...', ran to eight issues. ${ }^{10}$ Wilmot was the chief contributor. The often impudent tone of the journal was offset by a reverential attitude to Literature, Art and Creativity, a division which reflects an essential quality in Wilmot's life. His memories drew upon the somewhat disordered world of his father, the working-class associations of North Fitzroy, the raw vitality of the Book Arcade and the popular music hall entertainment offered in the slightly dubious atmosphere of the Gaiety and Bijou theatres. Yet he also aspired after a more elevated, dignified and serious world of high creative endeavour.

Wilmot's seriousness about Art was evident in his concern not to soil creative gifts by turning them to worldly ends. The nasty consequences of literary opportunism were the subject of a slight short story of Wilmot's in Microbe. ${ }^{11}$ The story concerned an artist, musician and poet who had abused his creative gifts in his pursuit of public renown. However, his conscience would not rest. The artist could not forget that despite his achievements and community esteem his work lacked 'the one virtuous element of sincerity'. 


\section{Dream and Disillusion}

The story ends with the progressive descent of the artist into spiritual darkness and creative death. Threading the story was the belief that betrayal of the imagination for worldly prestige led inevitably towards an impoverishment of art and society. As he gained maturity as an artist, Wilmot discovered that the distinction between art and the world was not as clear-cut as he had cnce supposed.

At about the time of his involvement with Microbe, Wilmot was drawn towards the novels of Conrad, finding there perhaps a more complex study of blighted lives than his own youthful abilities were able to encompass. He wrote admiringly of Conrad's power to portray the 'damnable influences' which eroded the normal pattern of men's lives and persisted 'to blight them forever'. He also declared that Conrad's great imaginative achievement lay in his ability to take the common experience of ordinary men and make it 'impressive and dramatic'. Wilmot associated Conrad's gifts with 'wide and diverse experiences' and with a spirit of 'masculinity, manliness and of convincing maturity' which enabled him to 'see things as they are and steadily'. ${ }^{12}$ In a later article on Conrad Wilmot declared that the originality of his achievement demonstrated how 'little we know about ourselves, our commonest passions, our most ordinary and immediate surroundings. ${ }^{13}$ Accordingly, the influence of Conrad provided Wilmot with an argument for examining familiar, even ordinary experiences. Synge and Yeats played a similar role for Esson, as did Orage and the New Age for Palmer.

For Wilmot, Conrad's creativity was an outstanding achievement in a world which seemed hostile to art. He described this world in an article titled 'The Mystery of Progress' published in 1905 in which he claimed that 'the consuming iron tread of Progress ....' was gradually robbing life of its 'wonder' and 'of all the attributes that demand our reverence, or inspire us with awe'. Miserably, he pictured 'the stale flat and unprofitable plain of existence' which he saw arising from industrial society and city living; a cheap and nasty life of 'tabloid meals and excursions in dusty electric cars'. This diatribe was a protest against 'an effortless age' in which humanity seemed trivialised; an age in which 'soul and muscle and brain look vainly for space and occasion for expansion'. To Wilmot, life in this commonplace and diminished world no longer had the dramatic qualities of wonder, awe and mystery which he believed an artistic imagination demanded. Wilmot accounted 


\section{Frank Wilmot in Pursuit of Poetry}

for the few contemporary writers of stature as survivors who had retained some of the 'vital fire' which in better times 'before knowledge and experience were drained to the dregs, was possessed by every soul that breathed'. ${ }^{14}$

Themes which Wilmot raised in 'The Mystery of Progress' reappear in different forms in his poem 'Minor to Major' which was published in a London magazine in $19^{10}{ }^{15}$ This poem explores the limitations of a minor poet; specifically in relation to the achievement of Edmund Spenser. It explores the process by which the minor poet, conscious of the oppressive weight of past achievements and the frailty of his own talent, nevertheless overcomes his servility and claims the right to the poetic expression of his own experiences.

The characteristic condition of the minor poet was one of anxiety, restlessness, harassment and fear. His reflection on Spenser's achievement made him despondent. He felt that his own world was a sordid one in which he stood 'muddy-footed', unable to bring order from his surroundings, whereas Spenser had been able to transcend harassing circumstance. He wrote admiringly of the great poet's spiritual voyage to Heaven: 'Your soul outsoared the children of the sod.' Moreover, while Spenser had attained a spiritual awareness above that of ordinary men, he did not forget his humanity:

... your kindly glance turned where

The jaded toiler piles his day on day

That followed along to one grey, hopeless year.

While the great poet knew the pleasure, pain and uncertainty of human life, his strength and courage was measured by an ability to order experience. He proved the full human dimensions of his time, giving man a fuller expression of his humanity and a sense of the range and power of human emotion. Sensing the scale of this achievement, the minor poet was oppressed by the poverty of his own intellect. He was fearful that his inadequacy would be revealed by a failure to communicate Spenser's power to his own times. Although he had worked hard and felt deep desire, Spenser's magic, courage, and vision had escaped him.

It was some comfort to the minor poet, however, to feel that if his own inadequacy could not be excused, it could in part be explained by the times in which he wrote. While Spenser's powers seemed to co-operate with the spirit of his times, the minor poet 


\section{Dream and Disillusion}

felt that he was the wrong man appearing at a time hostile to art. The modern condition was symbolised by the town: a world which the minor poet felt threatened man's spiritual inheritance. Finally, although he was chastened by Spenser's power, the minor poet acknowledged that he had had a rich human experience and could write about it. Fear of failure, paralysis in the face of excellence and disappointment at the materialism of contemporary society were pushed aside as joy came 'flooding through'.

'Minor to Major' reveals some interesting problems of style for Wilmot. His reverence for a past literature of poise, grace and balance made him uphold the importance of poetic form, since he felt that anything less was almost incompatible with Art. Yet in stanzas where he lamented flaws in himself and society, his style became less formal, anticipating the more colloquial manner of his later poetry. Similarly, while there was an emphasis upon universal imagery, there were also occasional phrases with a local turn such as 'swagman fires' and 'wells of bush silence'. Within the formal framework of a received view of poetry, Wilmot was experimenting with styles which suited his own poetic temperament.

The central concern of 'Minor to Major' is the problem of writing. In the poem, Wilmot celebrated a period of release, where he asserted his right to be a poet and proclaimed his new delight in the world around him. This theme also occurs in Esson's writing at this time when he discovered the pleasure he could take in work and looked back with distaste upon the futile languidness of the old Bohemia. Palmer also expressed an early self-consciousness about the act of writing in his letter to Nettie Higgins in which he confessed that his literary aspirations sometimes struck him as priggish. However, he also grew more confident of what it was to be an Australian writer once he had asserted his right to be patriotic.

As a young man Wilmot's concern for literary excellence, evident in his admiration of Spenser, prompted him to make some hard judgments on local literary standards. 'Abjuring the study of rudiments,' he wrote in I 909 , 'we stride to the summit of Olympus and find admittance to the temple on complimentary tickets issued by our friends'. ${ }^{16}$ The comment recalls 'The Brady-Esson Sanatorium for Decayed Dreamers'. On another occasion he observed: 'we have in our excitement analysed every stray bit of floating feather and found it a complete and delightful swan'. ${ }^{17}$ At its worst Wilmot feared that the celebration of local talent would not foster Art but mutilate it. He insisted that Australian literature needed 
'seriousness and veracity' and he probably had the Bulletin in his sights when he later wrote that we have:

the frills; we have a maudlin pathos, and a wild hilarity that is certainly not cheerfulness; brutal ideas and a quick stinging prose style we have; but ... for truth, the love of beauty, the sure vision and the direct statement, the sense of form and balance, where are these?18

In reaction, he stressed the need for dignity, care and purpose in Australian literature, altogether soberer qualities than he associated with the Bulletin.

Although Wilmot was adamant about the need for higher standards in Australian literature, he was less assured when he wrote about the role of literature in modern society. In the years before World War I, two principles that were not easily reconciled recurred in his critical writings. Wilmot saw the need for the creative writer to protest against the trivialising conditions of modernity symbolised by the worlds of commerce, industry, the city and the suburb, yet at the same time he was also attracted by the idea that art should explore the ordinary circumstances in which men lived. Neither position alone gave Wilmot much comfort. He was uneasily aware that protest could become a habit and lead to a remoteness from the social conditions which surrounded the writer. He charged Bernard O'Dowd with this offence, accusing him of 'Doing the heavily-fisted sublime', in his practice of 'poetry militant'.19 However, he was also conscious that the ordinary could become merely dull and an offence against the higher demands of literature. Much of Wilmot's effort as a poet and critic was given to a reconciliation of these principles. In this respect Wilmot had something in common with Esson, of whom Vance Palmer wrote: 'He was ... a romantic, driven, like Flaubert, by a sober compulsion to turn away from romance (from the subjective, the remote, the picturesque) and occupy himself with homespun realities'. ${ }^{20}$

Still perplexed by the proper relationship between his guiding principles, Wilmot asked in 1911 if there could be 'consonance between the apostle of the fact and the apostle of the dream?'21 His question recalls Esson's statement several years earlier that the 'Prometheus of the Australian imagination was fettered to the mountain of British Fact'. ${ }^{22}$ For both writers 'fact' represented the limitations which they felt industrial society placed upon the creative imagination while 'dream' represented the yearning for a juster 


\section{Dream and Disillusion}

and more creative society. After exploring his question Wilmot felt that the only thing which adherents of the two principles had in common was their ultimate ignorance of the forces moving man. Wilmot then made a curious statement which showed some relish for the modernity he regarded with such disfavour and considerable vagueness in relation to the aspirations of the 'dream'. He wrote:

Beyond the spidery iron buildings, ... the showering flames of the converters, moves ... the unknown faith whose influence the coldest intellect cannot shake off. For it is from the primeval sentiment, the soft call in the heart, that all great movements have had their inspiration, and their destruction. Only when we see, by the aid of literature and history, the action of this overwhelming flood do we realise the full meaning of the word irresistible. ${ }^{23}$

It is fair to suggest that Wilmot saw more in the immediate beauty of the converters than he acknowledged and less in the vague abstraction of 'primeval sentiment' than he cared to admit. In short, he was shifting his ground.

In I9I3 Frank Wilmot sent a manuscript to Harold Monro, then editor of the Poetry Review in London, and later publisher of the five volumes of Georgian Poetry. Monro regretted that he could not publish Wilmot's work for he found it difficult to judge. ${ }^{24}$ It may have been standard comment on a rejected manuscript, but against the background of English poetry in 1913 Wilmot's poetry would have appeared a strange mixture of the formal and the apologetically colloquial. He was hardly a Georgian poet in the style then emerging, but since he sent a manuscript to Monro, Wilmot may well have been interested in Monro's views on poetry without perhaps quite understanding how his own poetry would be affected. At the time Monro maintained that poetry could not remain aloof from social, economic and political issues and should not be thought esoteric and remote from everyday life. In The Georgian Revolt 1910-1922, Robert Ross wrote that: 'By 19ro, from out of his creed of Fabian social and political liberalism he [Monro] had begun to fashion some abiding convictions on the place of poetry and the task of the poet in the new age'. ${ }^{25}$ Given Wilmot's own socialist background, these doctrines may have come as a provocative call to accept the contemporary world as a fit setting for poetry.

The first real evidence of his interest in the emerging Georgian poetry came in 1916 when Wilmot wrote a review article on Rupert Brooke. He was enthusiastic: 


\section{Frank Wilmot in Pursuit of Poetry}

a quality that makes the work so promising is the poet's violation of poetic tradition, his ruthless epithets, his apparent confident belief that a sudden white-hot cry of indignation will not shatter down a poem conceived in a gentler mood. Such a practice means promise because it is brave ... ${ }^{26}$

Wilmot had once praised poetry almost exclusively in terms of its grace, poise, balance and respect for the traditions of the past, but in Brooke he was excited by qualities which promised a new impetus in poetry. His 'violation of poetic tradition' did not also imply a loss of quality, even though terms like 'ruthless', 'sudden' and 'shatter' were needed to describe the style and effect of his poetry. After Brooke it was possible to look forward to a poetry of innovation set in the contemporary world.

Wilmot's concern to balance the present and the past was evident in 'Some Celtic Writers and the Celtic Movement', an article he wrote in $1917 .{ }^{27} \mathrm{He}$ declared that 'the complexity of modern life consists of ... an effort to assimilate the new without rejecting the old, and the relative influence of one and the other is regulated by temperament'. Wilmot went on to express his reservations about both the Irish and the English temperament. His desired Australian temperament stood between the two, selecting what was best in both, but imitating neither of them. In Wilmot's view national character was not determined only by conditions in the physical environment. He considered the gradual development of generalisations about the characteristics of other nations were as influential, for they in turn, he believed, shaped views on what was the ideal national character for Australians.

In Wilmot's view the Celtic spirit drew sustenance from the dreams, the myths and the legends of the past, but he saw little ability to order this past or to provide a cutting edge for the future. The Irish, he insisted, do not live in the past, 'they are the past'. ${ }^{28}$ Moving to the Celtic movement in literature Wilmot felt that its aims contradicted the Celtic spirit. The movement, he declared, demanded order and self-proclamation, qualities that the spirit repudiated, for the Celt could only 'gain force in the present by renouncing the past, and a Gelt without his past is a negligible quantity'. ${ }^{29}$ However drawn he was to the Geltic past, Wilmot was convinced of the basic ineffectuality of the Celtic spirit. Comparing English and Irish qualities, Wilmot wrote: 'The trouble with the Englishman is that he has found his dogma. If anything ... his centre of gravity is too certain, while the Irishman's centre of being 


\section{Dream and Disillusion}

is spiritual and therefore uncertain, without order, amenable to no command of reason'. 30

Wilmot could not accept the Celtic spirit: 'this living in and for the past is wrong' ${ }^{31}$ His firmness on this point was matched by a more tolerant attitude towards 'progress' than he had shown in his 1905 article on 'The Mystery of Progress'. He now claimed that although no one really knew what progress meant and if it was right, there was nevertheless a law of development which men had to live by. 'That', Wilmot insisted, 'is the dogma we must anchor ourselves to', for he saw it as a basis for reason and purpose in human affairs. ${ }^{32}$ It was a point of view which he felt would prevent the Celtic tendency to obscure the social reality which lay beneath the legend and myth of the past. Although fascinated by the Geltic movement, Wilmot was more impressed with Rupert Brooke as a guide to the future of poetry. His attitude achieved a break with the 'eternal'. As Wilmot asked bluntly in 1917: 'Who wants to be told that the beauty of the world is eternal. It is not a memory, it is a reality .... ', ${ }^{33}$

Wilmot was concerned to understand and influence the quality of mind the Australian people brought to the task of shaping their nation and developing its intellectual or cultural traditions. $\mathrm{He}$ saw the need for a people capable of adjusting to the complex demands of the modern world. He was convinced that the attitude of mind best suited to the modern world was not Celtic. He preferred a mind capable of seeing the social reality that lay behind dreams and legends; a mind capable of acting in the real world for the betterment of the human condition; a mind sensitive to the necessary restraints upon human power. These convictions had weathered Wilmot's temperament and were to influence his poetic style. Wilmot's changing approach to the language of poetry reflected his need to find a proper scale for the Australian future. As the harsher realities of World War I became known, the optimistic predictions of a glorious future which had been a commonplace of the pre-war years looked absurdly inflated. Wilmot learnt to guard and qualify his idealism with irony, sardonic humour and familiar language. In doing so, he regulated his temperament to the demands of a world in which, after a period of war and massive destruction, optimistic prophecy was discredited. After World War I, Wilmot felt more assured of the need to discover a language suited to his familiar surroundings and his more subdued post-war mood. 


\section{Frederick Sinclaire: Socialist and Dissident Minister of Religion, I 908-I9I 5}

Palmer, Esson and Wilmot were all attracted to socialism. In the years before World War I the main vehicle for socialist thought in Melbourne was the Victorian Socialist Party. The party emerged from the Social Questions Committee which had been formed in 1905 to examine the extent of poverty in Melbourne. Tom Mann was the moving force behind the committee. Mann, an energetic and internationally known British labour organiser, had arrived in Australia late in 1902 and had soon become active in the Australian labour movement, particularly in Victoria for he based himself in Melbourne. Bernard O'Dowd, then editorially connected with Tocsin, was also closely involved with the Social Questions Committee. In March 1906, the 800 members of the Committee formed the Victorian Socialist Party. Tom Mann became secretary and first editor of its weekly journal, the Socialist. ${ }^{1}$

The Victorian Socialist Party emerged at a time of Conservative dominance in Victorian politics. Just over two years before the founding of the Party 'iceberg' Irvine, an Ulster Protestant and barrister, won a resounding victory on an anti-labour platform. Within nine months of his election the State of Victoria was 'sharply divided' over what the Argus described, weightily, as 'the most momentous strike in the history of Australia'. As Benham and Rickard have shown, the election of 1902 and the subsequent strike revealed fundamental realignments in Victorian politics. ${ }^{2}$ By 1903 the middle ground of 'liberal-labor alliance that had so dominated Victorian nineteenth-century politics' had become divided between a Labor Party forced to plot its own political course independent of the liberals and anti-Labor governments in which conservatives were influential and often dominant. It was indicative of these changes that the Age sided with its traditional 


\section{Dream and Disillusion}

rival the Argus, in its enthusiastic support for the government during the railway strike. Both papers made much of the public support for the government and portrayed the strike as a contest between the will of a law-abiding citizenry and a handful of mutinous and irresponsible strikers. Faced by a conservative press in a largely conservative community, the future of Labor in Victoria looked bleak in 1903 and proved to be so.

Federally, the promising achievements of the first Parliament in matters of social legislation soon bogged down in 'the arid manoevring of $1904-5^{3}$ in which period Deakin, Watson and then Reid all failed to form lasting ministries. It was against this background of political frustration in Victoria and stalemate federally, that Louis Esson wrote of his disillusionment with the existing political parties and called for the formation of 'The Young Australia Nationalist Party'. At this time Louis Esson and Frank Wilmot were in their mid-twenties. Vance Palmer was a few years younger. Their experience of political life in Australia was limited and disappointing for young men impatient for change. Although the Victorian Socialist Party was not the organisation Louis Esson had envisaged, it supplied some of the political contrast and dramatic appeal he had looked for in vain among the existing parties. For Louis Esson, the 'socialist tiger', which made frequent menacing appearances in the Federal Election of 1906 , was more a beast to be admired for his vigour and provocative behaviour in a dull community than deplored as a threat to the livelihood and political good sense of honest citizens.

Under Tom Mann's tolerant guidance the Victorian Socialist Party generated a diverse, even unruly range of opinions, many of which were expressed in religious forms and language. There were Socialist Sunday schools and Mann delivered 'Socialist Sermons'. ${ }^{4}$ In borrowing religious terminology, socialists were not concerned to parody religion, but to suggest that in many respects their own beliefs and practices came closer to the spirit of Christian teaching than did orthodox Christianity. While leading socialists in the party were critical of church teaching, there was also a strongly represented feeling that religion was too often dull and hostile to pleasure. Simply stated, many socialists believed that Melbourne could have been a more just and more joyous city. A variety of meetings, concerts, dramatic events and educational classes together with the prospect of congenial company helped the party to grow, until by August 1906 the membership stood at around 1500.5 


\section{Frederick Sinclaire}

One of the targets of the newly established Victorian Socialist Party was the churches and their neglect of poverty and unemployment in Melbourne. In the winter of 1906 the problem was dramatised by unemployed 'sit-ins' at major churches. Scots Church received a visit in June which turned out to be one of the most turbulent and widely publicised. About 170 people were reported to have entered the church and settled themselves towards the front of the congregation. The service proceeded smoothly until the Reverend Dr Marshall prayed, 'Bless the rich, O Lord, and make them poor in spirit' which brought forth a 'little groaning', but silence was restored as Dr Marshall began his sermon on the immortality of the soul. When the Reverend Doctor stated that without life after death there could be no respect for authority, a loud 'hear, hear' burst from the ranks of the unemployed. Marshall proceeded, but he was frequently interrupted and cries of 'rot' were common. 'This epithet', the Argus recorded, 'was eagerly repeated by a great number of the unemployed'. After several more dramatic interruptions, the uproar became so great that the sermon and the Benediction which followed could not be heard. At this point the preacher returned to the vestry and the regular congregation disbanded, leaving the unemployed and the choir in possession of the church. As one enthusiast called for three cheers for the social revolution Tom Mann tried unsuccessfully to enter the vestry against the will of church officials and bring Dr Marshall to face the unemployed. ${ }^{6}$

An Argus editorial deplored the incident and a supporting article alluded to the 'widespread disgust' it had caused. In a later note the paper attributed interjections to 'a crowd of men and women associated with Tom Mann'.7 There can be little doubt that for many churchgoers the 'sit-ins' struck at the basis of a Christian society. For their part the socialists wanted not only to dramatise the evasions of church leaders in relation to poverty and unemployment, but to express a more general hostility to organised religion. In many cases such feelings derived from deep-seated doubts about the ability of the church to guide and comfort modern man.

Melbourne and the Victorian Socialist Party were soon to gain a churchman with similar doubts. He was the Reverend Frederick Sinclaire, the first minister of religion to join the party. ${ }^{8}$ In I 1 I 1-12, Sinclaire co-edited the Socialist with Marie Pitt and as head of the Free Religious Fellowship he edited its magazine, Fellowship, which ran from 1914-22 and to which Esson, Palmer and Wilmot all made 


\section{Dream and Disillusion}

regular contributions. Frederick Sinclaire proved an asset to the Victorian Socialist Party. He was well read, a gifted and sardonic speaker and a fine singer. By the standards of his day he had none of that hostility to life's pleasures either in his own life or in other people's which discredited so many of his colleagues. He believed that social responsibility was not incompatible with warmth or enthusiasm. For Sinclaire, it was part of his personal mission and religious purpose to combat boredom, lack of purpose and deadening routine, particularly in a society in which the religious spirit was often censorious, prurient, conservative and narrowly respectable. He was a man prepared both to question the basis of his Christian belief and to broaden his teaching as new or unorthodox truths seemed to require. Accordingly, he often defied the values of his fellow clergymen and sometimes clashed openly with them. Sinclaire has the mark of a defiant temperament unwilling to submit readily to conventional opinion; an attractive quality for those who were also young, bright and fired with hope for a better socialist future.

Frederick Sinclaire was born on Io July I 88I in the Papakura Valley near Auckland, New Zealand. His parents were Irish born. His father, John Sinclaire, a farmer, was born in Cushendall, County Antrim, in $185^{\circ}$ and his mother, Mary née Carson was born in Belfast in 1854 . Their son, Frederick, was a clever boy and in 1893 he was enrolled at Auckland Grammar School after winning a Rawlings Scholarship which entitled him to free tuition and free books along with $£_{\text {Io }}$ per annum for three years. ${ }^{9}$

After six years at Auckland Grammar, where English, French, German and Latin were his main subjects, Sinclaire won a scholarship to Auckland University College where he began an arts course in 1899, winning in that year the university prize for English and gaining class I passes in Latin and French. He graduated in 1902 with an arts degree and in the following year completed a Master of Arts.

At this time Sinclaire came under the influence of the Reverend William Jellie, a Unitarian, who persuaded him to study for the Unitarian Ministry. ${ }^{10} \mathrm{He}$ enrolled at Manchester College, Oxford, in 1904 where his fees were paid jointly by the college and the British and Foreign Unitarian Society. In his third year Sinclaire won a Dr Williams Theological Scholarship open to Nonconformist students for the Ministry in England. ( $\mathrm{He}$ is one of only three Unitarians to have won the scholarship since 1900.) Sinclaire crowned his fourth year with a First Class in the college examinations 


\section{Frederick Sinclaire}

and a prize for his essay on the doctrine of the soul in Greek religion. ${ }^{11}$

From the scanty evidence available Sinclaire emerges with an early reputation as a brilliant student and sharp controversialist. Mrs Alan Mulgan, recalling him at Auckland University College, referred to him as a rebel, but without detailing the nature of his rebellion beyond the fact that his desire to become an Anglican minister was forestalled by his final inability to accept the thirty-nine articles. ${ }^{12}$

Sinclaire was one of the more provocative and original personalities at Manchester College. Poz, a student magazine of the time, pictured him with uneasy amusement as a vocal Shavian with an eye for the ladies. ${ }^{13}$ There were also jibes at his nationality. ' $E$ his from furrin parts', one humorist wrote 'and shows hit' and again: 'In your enthusiasm for your native land we sympathise with you, you are still young, and, as you grow older, will see things in their proper perspective.' He was then in his early twenties. Poz later announced Sinclaire's departure for 'Smelbourne'. Sinclaire, however, seems to have derived less pleasure from Manchester College than Manchester students seemed to have derived from him. In a parody in Poz titled 'Lament over Oxford, by a New Zealander', he wrote in part:

This city now doth like a garment wear

The cerements of intolerance: a proud air

Of vast aloofness on its face doth lie:

It blinks in awful ignorance to the sky

Whereon it gazes with a blank, blank stare.

Soon after his arrival in Melbourne early in 1908 Sinclaire wrote to Tom Mann requesting a verbatim report of his recent 'Socialist Sermon, a Challenge to the Ungodly Religious'. ${ }^{14}$ Sinclaire was anxious to answer this challenge. He declared that he would be 'glad of an opportunity to put in a word of apology on behalf of the churches' and went on to regret that socialism and religion were often assumed to be antagonistic. However, he was apologetic about the performance of the churches and believed that they bore much of the responsibility for the breach. Mann arranged for Sinclaire to address a regular Sunday meeting of the Victorian Socialist Party at the Bijou theatre under the title 'Socialism and the Churches'.

The meeting was crowded: 'Every chair was occupied and the 


\section{Dream and Disillusion}

walls were lined with eager faces'. ${ }^{15}$ In the crowd were members of the Eastern Hill Unitarian Church anxious to hear their new minister 'take up the cudgels with Tom Mann'. As he ascended the stage Sinclaire was greeted by a 'hearty round of cheers'. In a calm voice he argued that over the preceding thirty years the churches had changed their theology. Doctrines such as eternal punishment, belief in the literal truth of the Bible 'and other superstitions were not now taught'. The churches were becoming aware that they needed a greater knowledge of the social conditions in which people lived in order that 'a knowledge of correct economics and the inspiration of the church ... ' might combine to the general benefit of mankind. Sinclaire called for a more charitable attitude towards the churches and their efforts to serve humanity in order to prevent 'a widening of the breach between the churches and the people'.

It was reported that the audience responded warmly to Sinclaire's address 'as they recognised a community of thought and desire for the general welfare'. Whether or not he had answered Mann's challenge, which claimed in substance that the churches had departed from the teachings of the Bible to the point where they were supporting the ruling classes against the poor and oppressed, was left to individual decision. It was thought that Sinclaire acquitted himself well and that his views deserved respect. However, the need to re-think the relationship between religion and socialism was postponed by the observation that Sinclaire was not an 'Orthodox Churchman' and that 'His apology for the churches was purely a matter of sympathy or charity'.

In September 1908 a Fabian Society was established in Melbourne by Bernard O'Dowd. Sinclaire became its first secretary. Soon afterwards, another group, the Social Science Club, was formed to satisfy those like Nettie Higgins who had reservations about committing themselves directly to socialism. Unlike the Fabian Society, the Social Science Club did not require its members to be socialists. ${ }^{16}$

In October 1908, Sinclaire gave an address on the Incarnation to the Social Science Club in which he sought theological justification for his socialist beliefs. He argued that the world had been created by a 'lesser God, an artificer of God' who was responsible for 'the laws of nature' and many established human laws of retribution such as 'Might is Right' and 'An Eye for an Eye'. Sinclaire described these as lesser laws which in the course of time would be gradually displaced just as 'God himself, became man', meaning that 'the 


\section{Frederick Sinclaire}

human spirit received into itself and as part of itself, a portion of the Divine Spirit'. This transitional process accounted for the tension between old laws and new which pressured men to become 'agitators, reformers, poets and martyrs for humanity's sake . . ' '.17 Sinclaire considered such men vital to civilisation and a source of spiritual enlightenment. For Sinclaire, Bernard Shaw was one such man.

In September 1908, Sinclaire gave an address on Shaw to the Melbourne University Literary Society. He declared Truth and Romance to be incompatible and upheld Shaw as the champion of truth. 'Romance', he asserted 'was the anaesthetic which prevented us from seeing things in their reality, and makes canting humbugs of us.' ${ }^{18}$ Sinclaire's attachment to Shaw led naturally enough to an involvement in the theatre. Soon after his address to the University Literary Society, he wrote a 'Plea for an Adult Theatre' for Trident. Warning that 'it is as well to begin by facing the worst', he did so by looking at the state of the theatre in Australia. $\mathrm{He}$ found a lack of enterprise and originality: 'We have not even the beginnings of an Australian drama, not even a school where young Australians may learn the rudiments of their craft as actors.' Sinclaire argued that Australians would have to reject the secondhand and second-rate products of London's commercial theatre circuits before they could command the skills and the audience required for the development of a repertory theatre in Australia. ${ }^{19}$

It is evident that Sinclaire did not exert himself for a future society which differed in its economic structure alone. In a review article in 1908 , he regretted that 'Contemporary Socialism is still in bondage to the crude dogmatic materialism of Marx ....' Like Louis Esson, Sinclaire believed that Marxists 'fail to realise that the philosophic thought of the last fifty years has put materialism entirely out of court as an explanation of the phenomena of life.... Popular socialism', he continued, had better 'undo the mesalliance with obsolete philosophic theories before it can command the allegiance of educated men and women'. ${ }^{20}$

As an educated man speaking on behalf of socialist principles, Sinclaire gave his views on prostitution. In an article on the subject to the Socialist he noted that nothing had been done to alleviate prostitution because 'we are too cowardly, too brutal and too hypocritical'. ${ }^{21} \mathrm{He}$ wanted prostitution recognised as a social problem which demanded the analytical skills of sociology, not the moralising of churchmen. Sinclaire also addressed a packed 
Bijou theatre on 'The Shame of the Streets'. It was recorded that the meeting was 'a tribute to the splendid courage of the Rev. F. Sinclaire in handling one of the social cancers of civilisation'. Sinclaire did not appear until 'after church' and when he did was received with a 'storm of applause'. ${ }^{22}$ Attention was paid to the manner of the speaker for he was calm, critical, deliberate and careful to avoid extravagance: 'It was the method of Science and the manner of Reason' and altogether consistent with the fine impression Sinclaire had created at his first Bijou lecture.

Sinclaire's advocacy of socialism and his views on moral questions like prostitution brought him into direct conflict with the great majority of his fellow clergymen. Sinclaire believed that too many churchmen sought to justify economic hardship in terms of honest poverty and character-building self-denial. These ministers were often quick to condemn any back-sliding or moral frailty, but refused to see, or were unable to see, that the social system weighed unequally and unfairly on its citizens and was a factor producing crime and immorality. By contrast, Sinclaire insisted that the injustices of Australian society were not merely unfortunate aberrations, but were based on self-perpetuating inadequacies in the social system. He wanted churchmen to recognise that changes in the structure and moral assumptions of their society were essential if the immoral and the brutalised were to be changed into upright citizens. Sermons which chastised evil doing and applauded good were dismissed by Sinclaire as the routine humbug of small, sheltered and complacent minds.

Soon after his arrival in Melbourne, Sinclaire outlined his views on poverty and immorality in a letter to the Argus. The precipitating issue was the statement made by a Labor senator in May 1908 that a bank clerk had been gaoled 'for having done to his employers what his employers had done to him for years'. The senator argued that the employers had robbed the clerk both of money and time as the salary was low and the hours long. An Argus editorial called this a 'grossly immoral' and 'intolerably outrageous' doctrine against which 'all men of manly and moral tone ... will revolt immediately'. Sinclaire, however, recorded his 'entire agreement' with the senator's remarks and in doing so made 'a public confession of unmanliness and immorality'. He argued that if it was wrong of the bank clerk to rob his employer it was also ethically wrong for the employer to underpay the clerk. While there were differences in the way each case was treated by law, Sinclaire felt that there 


\section{Frederick Sinclaire}

was no clear-cut moral distinction between the two acts. He concluded:

It is time we heard the last of this Pecksniffian cant about honest poverty, and began to face the plain fact that poverty is the mother of every kind of sin. Remarks about the itching fingers of bank clerks come ill from those who condone the anarchical scramble for wealth which constitutes three-fourths of our civilisation. ${ }^{23}$

Sinclaire signed himself, Minister of the Melbourne Unitarian Church.

In the week that followed this letter, Sinclaire's views, which the Argus called 'the new morality', were attacked by both the 'manly' and the 'moral'. ${ }^{24}$ Sinclaire was pictured as a victim of faulty logic, an advocate of dishonesty and a discredit to his profession. The critics included two bank clerks anxious to defend themselves and their colleagues against allegations of unreliable moral character, although Sinclaire had made no such allegation. In a further letter, Sinclaire declared that he was not questioning the legality of an individual act of robbery but the ethical context in which the act took place.

He implied that personal frailty was not the sole cause of crime and maintained that the criminal act must be examined in relation to the moral assumptions prevailing in a capitalist society. He also dismissed the argument that the man who consented to his oppression thereby removed or lessened the injustice that was done. 'A rightly ordered community', he maintained, 'will not allow any of its members to be sweated, even though they themselves consent to it. ${ }^{25}$ Sinclaire's attacks upon the doctrine of respectable poverty drew only one letter of support; or more precisely, the Argus published only one such letter.

The 'new morality' expressed in Sinclaire's letters to the Argus was anathema to another man of the church, the Reverend W.H. Fitchett. Fitchett, a prominent Melbourne Methodist and educationalist, was editor of The Southern Cross: A Weekly Journal of Religious Literature. He was also the author of a number of best-sellers, including Fights for the Flag and Deeds that Won the Empire which dramatised patriotic virtues. ${ }^{26}$

Sinclaire and Fitchett essentially differed in their basic assumptions on the nature of Australian society. Unlike Sinclaire, Fitchett considered that Australia was a just and democratic community which catered fully for the essential needs of all its citizens. He felt 


\section{Dream and Disillusion}

that democracy in Australia had reached its final flowering. Any problems that remained were moral in nature, not social or political. As he announced in September 1908: 'The root of all the troubles of the race is not social, or political; it lies in the moral realm and must be healed by moral forces'. This comment formed part of his analysis of the 1908 Sydney tramway strike, a strike which he indignantly dismissed as an absurdity 'in the land where freedom has spoken almost its last word and labour has come into its kingdom ... '.27 By March I9I I Fitchett was able to announce the complete triumph of democracy. 'We have come to the ultimate form of democracy,' he declared in The Southern Cross, 'All the great interests and conquests of civilisation - order, freedom, prosperity, social peace, the home - in regard to these absolute power has passed into the hands of the people.'28

According to Fitchett, a free and equal society without class privileges had finally been achieved in Australia. However, he did not maintain that this situation had eliminated hardship. Hardship, he felt, belonged to a natural order in human affairs and could not be eliminated. Each man had to learn to accept the hardship of his own particular circumstances. He argued, for example, that 'the perils of a miner's life' were 'natural to his calling' like those of a soldier or a sailor. These dangers represented 'no crime on the part of the employer' and 'the miner accepts his employment knowing its risks'. ${ }^{29}$ Fitchett pictured the situation as one of peaceable integration where even the humblest and most hardworking citizen was reconciled to his own place in the natural order of the community.

With these views, it is not surprising that Fitchett should have objected so strongly to Sinclaire's letters in the Argus. Whereas Sinclaire maintained that criminal acts might often be traced to social injustices, Fitchett argued that crime and immorality in a democratic country like Australia could not stem from inequality but must be the expression of individual moral weakness. Fitchett, therefore, had little sympathy for the common criminal who he felt wantonly sinned against an otherwise blameless community. He urged the offender to improve the standards of his behaviour and to find the moral strength to become a good citizen. He swept aside Sinclaire's ignorant prattle about the 'new morality' and announced that 'Poverty has its moral risks, but moral character is trained and developed by the wrestle with temptation, not by the absence of temptation'. ${ }^{30}$ 


\section{Frederick Sinclaire}

Since Fitchett believed that hardship and pain were natural elements in any society, even the most democratic, he dismissed reformers who sought to make men's lives more comfortable. He felt that too many reforms merely softened men and one of his major concerns was that the 'ease-loving' attitudes of modern life were leading to degeneracy and moral decay. In his books he was anxious to emphasise patriotic qualities. He celebrated the 'heroic fortitude', the 'loyalty to duty stronger than the love of life', the spirit 'which dreads dishonour more than it fears death' and the 'patriotism which makes love of the Fatherland a passion'; virtues which had won the Empire 'in a sterner time than ours'. ${ }^{31}$

In October I908, under the heading 'Fatty Degeneracy of the Soul', Fitchett told readers of The Southern Cross that 'the temper of the modern world grows ease-loving in a perilous degree. And the love of ease - of easy ways of duty, and easy conceptions of life - spreads everywhere with the speed, and the deadly offices of a dry-rot'. ${ }^{32}$ In the following year, Fitchett referred to the 'many things' such as a benign climate and 'our easy social conditions' which kindled in 'Australians a passion for pleasure which has the temperature of a fever'. ${ }^{83}$ Later he accused Australians of catching 'the Parisian temperament' and warned that 'Pleasure and pain alike have their characteristic risks. Pain hardens. Pleasure enervates'. ${ }^{34}$

Sinclaire also came into conflict with another Methodist minister, the Reverend W.H. Judkins. Judkins was a prominent campaigner against drinking, gambling and prostitution in Melbourne in the years between 1906 and 1912. With all the dramatic flair at his command, Judkins presented startling pictures of vice in the dens, alleys and parks of Melbourne and exhorted his listeners to tread the holy path of personal purity. He addressed dozens of meetings on moral questions and drew large crowds to the Pleasant Sunday Afternoon, which since 1893 had formed an important religious forum for the Methodist Church in Melbourne. ${ }^{35}$ Louis Esson's views of this institution may be deduced from The Time is Not Yet Ripe, in which Sydney Barrett announced that in his socialist utopia all Pleasant Sunday Afternoons would be suppressed.

Despite all his thundering on the evils of gambling and drinking, Judkins, like Fitchett; seemed unable to understand the possible social causes of the behaviour he wished to eradicate. He was not amenable to the argument that gambling and drinking taken in moderation were legitimate pleasures or that excessive behaviour 


\section{Dream and Disillusion}

was often caused by the miserable conditions in which the offenders lived. For some, Judkins must have symbolised a perverted idealism which attacked the pleasures of life without remedying the pain. Certainly, Judkins scored very well in a Gadfy plebiscite in $\mathbf{1 9 0 6}$ which was designed to discover Australia's five worst citizens. He ran second in a competitive field. ${ }^{36}$

Judkins came into conflict with Sinclaire over an address on 'some of the outstanding features of night life in Melbourne' which he gave to the Third Conference of the Social Reform Bureau in 19Io. Judkins had researched the topic by visiting two small parks in Melbourne after dark. He revealed, to cries of 'Shame!' and 'Awful!', that 'on a little green spot, about the same size of this church' he had counted thirty couples. Their purpose in being there was undisclosed, but Judkins noted that they were 'taking no more notice of passers-by than if they did not exist'. He said that his desire not to injure the feelings of any one class prevented him from naming those involved as shop girls. He evidently drew close enough to determine in the gathering darkness that: 'They were girls you might sit beside in the train, and imagine they were your own daughters.' Worse: 'You might have received them in your own houses.' Judkins added that for a picture of 'the real state of things' all that was necessary was to multiply the density of couples in the samples by the 'total areas in the city parks'. ${ }^{37}$

Frederick Sinclaire made the necessary calculations. He revealed his findings to an unusually large audience at the Gaiety Hall in a lecture titled 'Social Reform - The Gnat and the Camel' ${ }^{38}$ From the outset he warned his audience that he had had 'no hair-breadth escapes' and those who had attended 'to hear something spicy would be disappointed'. He then presented his calculations. On the basis of Judkins's figures he could only conclude that in 'the parks and gardens of Melbourne 9,000,000 people [were] engaged in objectionable conduct' on the night of the survey. Sinclaire was sceptical. He pointed out that he was prepared to believe that Melbourne was a 'veritable Sodom and Gomorrah, and that two out of every three people might be very weak, but not that 16 people out of every one was wicked'. That was too much. In more serious vein he declared that Judkins's calculations were an absurdity and revealed 'a type of mind and temperament which delighted in exaggerating the extent of the social evil in this or that city, a type of mind which was not fitted to deal with the subject'. 


\section{Frederick Sinclaire}

Sinclaire then criticised reformers whose solution to moral problems relied on police action and stiffer penalties. He pointed out that in many cases poverty made it almost impossible for some young men to marry. If they did marry and then obeyed the politicians exhortations to increase the birth rate they were then condemned for their 'imprudence and want of foresight' in having children which they could not adequately support. Sinclaire emphasised that 'repressive police measures and hour upon hour of talk' were no substitute for an investigation of the economic basis for social evils or for direct contact with the offenders in an effort to give them a 'taste for pleasures of real worth'.

Judkins, however, was unimpressed by Sinclaire's arguments. $\mathrm{He}$ declared that it was 'ridiculous' to attribute social evils to economic conditions. Moreover, to base a remedy for moral laxity on this supposition, he claimed, was 'like putting a sticking plaster on a volcano'. ${ }^{3 \theta}$

Sinclaire gradually became more outspoken in his criticism of the churches and more liable to abuse from orthodox churchmen. In the middle of 1909 he held six mid-day lectures on the subject of religion and modern man which again drew criticism from Fitchett in The Southern Cross. Sinclaire argued that the church had been reluctant 'to modify and restate its doctrines in modern thoughts and forms' and too often remained bound to 'ancient formula and dogma'. This conservatism, he maintained, made the church insensitive to the search for a better 'social order of things, for a world with more justice and less cruelty'. ${ }^{40}$

On a later occasion Fitchett attacked Sinclaire as a futile Unitarian. 'Unitarianism', he asserted, 'is the most helpless and ineffective form of organised Christianity the world knows. It is bankrupt of power. To what savage land', Fitchett asked, 'has it carried its mutilated gospel and by its magic changed cannibals into saints? What city slum has it ever purified?'41 Sinclaire later defended Unitarianism in the columns of the Argus and also upheld the spirit of recent biblical criticism against attacks from J. Laurence Rentoul, Professor of New Testament Greek Literature and of Christian Philosophy at Ormond College, University of Melbourne. ${ }^{42}$

As disapproval of Sinclaire grew more intense among his clerical colleagues, his reputation among socialists rose. Through I910 comments appeared in the Socialist praising Sinclaire's abilities. Socialists were reminded that his sermons at the Unitarian Ghurch were well worth attending, being 'probably the most intellectually 


\section{Dream and Disillusion}

thought-compelling and advanced ... in Melbourne'.43 Sinclaire also won a tribute from Frank Hyett, a fervent opponent of Christianity. The Socialist commented that Hyett's 'tribute to the braininess and "whiteness" of [Sinclaire] ... justified the hope that our clerical comrade was beginning to be recognised for the scholar, thinker and progressivist he is'. ${ }^{44}$ Later in the year after an address by Sinclaire on 'Socialism and the Theatre' it was noted in the Socialist that 'Comrade Sinclaire is a growing force in Melbourne, and slowly is compelling the recognition which is his due'. ${ }^{45}$

Sinclaire's efforts to reconcile his Christianity with socialist teachings was of vital concern to socialists from a Christian background such as Nettie Higgins and Vance Palmer. It is evident from her letters that Nettie's attitude to religion was a subject of sorrow and concern to her mother. In September IgII, soon after her engagement to Vance Palmer, Nettie wrote: 'I have been trying so hard to explain to you Mother dear, that in your strictest sense I am not "God-fearing": and for that reason a man who was so would not be my mate'. Nettie tried to explain that her views did not make her 'irreligious', if that term meant 'something wanton and irresponsible and selfish'. Of herself and Vance, she declared:

We are people so made that life inside a church would be for us too complete, so to speak. Any religion we have must be progressive and personal: we must win it for ourselves bit by bit as we get older, instead of finding full, sudden satisfaction in a converted life. ${ }^{46}$

Vance agreed with Nettie. He consoled her with the thought that when her father claimed that 'an irreligious woman was a monstrosity', he probably meant an irresponsible woman 'because', he added, 'all men feel that dimly although they do not often understand the nature of responsibility'. He believed that it was a mistake to view such a quality as the exclusive property of orthodox, churchgoing Christians. He preferred to regard responsibility as 'the submitting of one's actions to an infallible judge ....'. 'Conscience' was sometimes considered an alternative term, but Palmer felt that it had become too 'hedged with religious associations' and notions of obedience 'to fixed, unchanging laws of God'. 'We can't accept that', he wrote

but we can make an infallible judge of the highest truth we can 


\section{Frederick Sinclaire}

see at any one time, and let it try our actions .... This is a religion I think, since the need of an infallible judge has made all religions, and since it is recognized subconsciously by all really religious people. ${ }^{47}$

Nettie Higgins and Vance Palmer were anxious to show by their own behaviour and commitments that, although unorthodox in their religious beliefs, they were no less receptive to civilised values. Indeed, as socialists, they claimed that the churches, which made large claims for their civilising role, were nevertheless often indifferent to the demeaning circumstances in which the mass of men lived in what was otherwise called a civilised society.

However, even socialists might doubt whether civilisation would inevitably benefit by improving the lot of the masses. There was always the fear that civilised values might be overrun and ultimately barbarianised, rather than the whole society becoming more civilised. Bernard O'Dowd presented the problem allegorically in a letter to Nettie Higgins in 1908. He pictured a bridge extending across a volcanic abyss. Upon the bridge was 'a patriarchal group it seemed of the respectable, law-observing, "good" salt of the earth' and in the abyss 'the outcasts of the human race, struggling upward and by their struggles necessarily threatening the stability of the ... noble group of ... "elect" '. O'Dowd sided with the outcasts 'even though it meant the annihilation of that shining group ... and if anything my belief in the soundness of my choice grows stronger'.48

O'Dowd's letter, written only two years after the formation of the Victorian Socialist Party and at around the time of Sinclaire's arrival in Melbourne, was probably intended to show Nettie that it was not unusual to feel some doubts about a commitment to socialism. By 1910 , she was more assured about the basic correctness of socialist teaching and more doubtful about the value of orthodox Christianity. A similar transformation can be seen in the career of Frederick Macartney, another socialist, a close friend of Frank Wilmot and a member of Melbourne's literary community.

Macartney was born in Melbourne in 1887 . His widowed mother, who attended the local Methodist Church, gave her son 'a religious upbringing typical of the time'. ${ }^{49}$ Games, secular songs and secular books were forbidden on Sundays. The day was passed at Sunday school and church, and hours were spent reading the Bible, and other religious texts or in singing hymns to the 'accompaniment of a horrible instrument called the harmonium'. Macartney wrote: 


\section{Dream and Disillusion}

'I was taken to church even as a small boy, desperately bored but warned not to fidget'. When he was about fifteen Macartney graduated to church 'revivals' at which children 'were urged under a barrage of dismal hymns and prayers, to be "saved" ...'. At around the same time he attended an inter-church temperance organisation known as the Band of Hope. This featured 'addresses on the evils of drink' and songs celebrating the joys of water with refrains like: 'We love cold water and we'll drink it all our days' or 'My drink is water bright from the crystal spring'. At each Band of Hope meeting the children recited the pledge: ' $I$ promise by divine assistance to abstain from all intoxicating liquors as beverages and to discountenance all the causes and praccices of intemperance'.

Macartney found a more positive side to church activities when he joined the Young Men's Literary and Debating Society at the Methodist Church, but his growing interest in rationalist literature and his attraction to socialist ideas soon led him into heresy. An elder of the church heard of his apostasy and reprimanded him, an episode which helped him sever his connection with the Methodist Church. However, Macartney experienced no great sense of loss for he was sustained more and more in young manhood by imaginative literature. Having renounced the first half of the temperance pledge, he found his way to Fasoli's café where he made his first acquaintance with some of the writers of the day like Louis Esson and $E_{i} J$. Brady. ${ }^{50}$ At around this time he also encountered a more tolerant form of religion in the sermons of Frederick Sinclaire on subjects such as 'International Peace, The Brotherhood of Man and the Sacredness of Socialistic Aspirations'.51 Later Macartney joined the Victorian Socialist Party and made occasional contributions to the Socialist.

While people like Nettie Higgins, Vance Palmer and Frederick Macartney were attracted to and inspired by Sinclaire's ideas the more conservative members of his congregation were alarmed. By 1910 there was growing dissatisfaction within the Eastern Hill Unitarian Church over Sinclaire's conduct of his ministry. Unfortunately, church minutes for the period appear to have been destroyed, but the remaining evidence suggests that Sinclaire's socialist activities, his outspoken sermons, attended perhaps by some more interested in socialism than religion and his use of church rooms for meetings of the Fabian Society all created tensions between himself and church authorities. ${ }^{52}$ Early in October 1910, Sinclaire left for a tour of New Zealand which the Socialist hoped 


\section{Frederick Sinclaire}

would prove 'beneficial to health as well as successful in scope'.53

This may have been a holiday in which Sinclaire could think over his plans for the future, although it is also possible that he may have looked for prospects of employment in New Zealand. By February I 9 I $I$, the decision to leave his ministry seems to have been made; a note appeared in the Socialist to the effect that Sinclaire '(Melbourne's plain-speaking parson ... with a Shavian bias)' contemplated resigning his ministry to establish himself as a 'teacher of elocution, singing, voice-production and languages'. ${ }^{54}$ During 1911 , Sinclaire thought of leaving Australia but in November a group was formed which asked him to stay on at a salary of $f^{2}$ a week. Sinclaire's new ministry, the Free Religious Fellowship, arose out of this group..$^{55}$

In some aspects the Free Religious Fellowship resembled the Australian Church, a Presbyterian ministry formed in 1885 by the Reverend Charles Strong. Strong's expulsion from the Presbyterian Church has been well recounted in a recent study by C.R. Badger. ${ }^{56}$ Strong, like Sinclaire, was a man with firm convictions on the need for social reform. He was also the supporter of various worthy but unpopular causes such as the Anti-Sweating League, The Criminology Society and the Peace Society. Strong and Sinclaire agreed on many important issues and Strong contributed to the magazine Fellowship while 'Sinclaire preached and lectured for Strong'. ${ }^{57}$ From 1914 to 1918 they were united in their opposition to the war and both opposed conscription. ${ }^{58}$

Soon after his resignation from the Unitarian Church Sinclaire became co-editor of the Socialist. ${ }^{59} \mathrm{He}$ described himself as a 'tolerant' socialist, anxious to examine the various possibilities for the socialist state. But he was not lackadaisical in his approach. In a journal like the Socialist, the highest possible standards of intellectual debate were to be matched against a comparable standard of cultural excellence.

As editor of the Socialist, Sinclaire maintained his liberal acceptance of new ideas in literature and the arts. His socialist convictions were shaped by his close knowledge of nineteenth-century literature critical of the ethics of industrial society. He also had an extensive knowledge of less familiar modern writers such as Ibsen, Nietzsche and Bergson.

Sinclaire was probably influential in having Ibsen performed in Melbourne. In Igr I, Melbourne's first repertory theatre movement was started by Gregan McMahon. Sinclaire welcomed the move as 


\section{Dream and Disillusion}

'the most serious and important event that has happened in Australia for many years - Referenda, and Coronation festivities, and all the vanities of political history are', he insisted 'irrelevancies and trivialities by the side of it'. ${ }^{60}$ This enthusiasm is explained by his later observation that 'nine-tenths of the best dramatic work of the last fifty years is saturated with revolutionary thought. Success to the Repertory Theatre'. ${ }^{61}$ In 1912 Sinclaire addressed the second meeting of the Repertory Theatre Club on 'The Philosophy of Ibsen' and soon after this the Repertory Theatre presented $A$ Doll's House to the public of Melbourne. ${ }^{62}$ Sinclaire commented on their efforts in the Socialist: "we may congratulate ourselves on having among us a few enthusiasts whose work helps to redeem our city from outer barbarism. ${ }^{\prime 63} \mathrm{He}$ later published an article on Ibsen for the Repertorian. ${ }^{64}$

Before World War I Frederick Sinclaire saw history in terms of the broad development and slow triumph of enlightened thought. Although he was not a poet, Sinclaire probably saw himself as a rebel, perhaps even a martyr, after his resignation from the Unitarian Church. It is certainly true that he deeply respected the power of ideas to change the world for the better and he regularly invoked the names of great teachers of men: Shelley, Garlyle, Morris, Ibsen and Shaw.

Sinclaire's socialism was part of his wider search for the moral bases of a socially conscious and spiritually fulfilled life for modern man. His intellectual convictions were shaped by his theological training at Manchester College and his attraction to socialism, particularly in the writings of Bernard Shaw. In Melbourne, Sinclaire became more convinced that it was no longer adequate for men of Christian conscience to judge the actions of their fellow men without reference to the conditions in which they lived. By degrees Sinclaire found that his views met with a warmer reception within the Victorian Socialist Party than among his fellow clergymen. Indeed, churchmen were among his strongest critics. As his views became clearer, Sinclaire grew more adamant that 'the new morality' for twentieth-century men would push beyond the limits of orthodox Christianity towards a higher consciousness of the bonds of fellowship and responsibility which he believed were basic to a good society. Like Esson, Palmer and Wilmot, Sinclaire tried to make his actions and beliefs consistent with the ethical requirements of the new future which he discerned within the mould of the existing society. 


\section{6 \\ War and the Emerging National Gulture}

Much of what Esson, Palmer, Wilmot and Sinclaire hoped for in the decade before World War I is summarised in the following passage from Edward Carpenter's Civilisation: Its Cause and Cure. In 1889 Carpenter wrote:

now for the first time in History both the masses and the thinkers of all the advanced nations of the world are consciously feeling their way towards the establishment of a socialistic and communal life on a vast scale. The present competitive society is more and more rapidly becoming a mere dead formula and husk within which the outlines of the new and human society are already discernible. ${ }^{1}$

Carpenter invited 'thinkers' to choose competitive society or the goal of a communal life; a decaying present or a developing future; spiritual death or creative growth. In this scenario, those who chose socialism, the future and creativity joined an army of ordinary labouring people and thinkers; an irresistible and constantly growing force which would undermine and ultimately destroy the foundations of capitalist society. Carpenter's formulation gave the thinker a historical purpose, a goal, however ill-defined, an audience in the form of allies fighting for the socialist cause, and an enemy. $\mathrm{He}$ also provided an ideal of vitality, life and spirituality which he associated with the common people and images of sterile routine and spiritual death which he associated with the middle class.

One of Carpenter's central concerns was to establish the separate identity of socialist man and assure his ultimate triumph over 'competitive society'; a triumph of healthy simplicity over the disease of 'civilisation'. These and similar views proved appealing to an ambitious young man like Palmer who had suffered at the hands of consciously superior Englishmen. He could not feel at ease in English clubs or in a society which he knew to be more complex, more stratified and more tradition-bound than his own. 


\section{Dream and Disillusion}

But this mattered less when he discovered that his irritation and jealousy could be transformed into a socialist critique of civilised English society. As a socialist, Palmer could claim that he chose not to enter a world from which he was virtually excluded. While Palmer could not claim that Australia was a socialist society by any Nere Age definition or by Carpenter's standards, he felt that as a newer society it contained less entrenched opposition to the socialist ideal. Palmer felt that if Australia was not socialist in reality, then it showed signs of a socialist disposition. This placed the true Australia on the side of health, socialism, community and art and it allowed those who professed different beliefs to be dismissed as unAustralian. Although in this view Australia could not claim a truly distinguished past, it could contemplate a fine future. Such views reassured Palmer for they suggested that it could be exciting and historically important to be an Australian, not a misfortune.

The evolution of a new type of man, whether Carpenter's socialist or Palmer's 'true Australian', took time. The process was interrupted in August 1914 by the outbreak of World War I, an event which none of the major figures of this study had predicted or even, it appears, suspected. This is hardly surprising. There were a number of loose predictions of coming war in the decade before World War I, but misconceptions about the nature and duration of modern warfare abounded before the realities of the war began to emerge. Even so, the peculiarly acute and urgent demands of war meant that questions of loyalty and fundamental allegiance which were essential aspects of almost any definition of what it was to be Australian became hotly contested issues. Against the background of the war Palmer, Sinclaire and Wilmot were forced to define, defend and where necessary, modify social, political and literary commitments which they had shaped before the war. In the period from around mid-1915 to the second defeat of conscription in December 1917 all three men tried to detect, in Carpenter's words, 'the outlines of the new and human society' in Australian reactions to the war. In the two defeats of conscription in particular they found signs of a dawning national consciousness in the Australian people, signs of a desire to break free both from the limitations of 'competitive society' and from deference to Britain. As Chapter 7 will show, they were destined to be disappointed.

The timing of the war exasperated Palmer, Sinclaire and Wilmot for it came when they considered it crucial for Australia to develop a spirit of independence from Britain. While they stressed this 


\section{War and the Emerging National Culture}

need, and made much of whatever signs there were of a distinctive national spirit, they could not overlook the depth of loyalty to the Imperial cause in Australia or the fact that many Australians saw no difficulty in reconciling Imperial loyalty and a sense of Australian patriotism. Andrew Fisher, the leader of the Labor Government elected on 5 September 19 14, had pledged his support for Britain's war effort, while the Australian volunteer force was called the Australian Imperial Force, the A.I.F. As the war progressed Palmer, Sinclaire and Wilmot attributed much of the Imperial loyalty in Australia to the leaders of society, the politicians, the press and the churches, and argued that their views were not necessarily representative ones. In this manner they kept alive their pre-war hope that the ordinary people remained allies in the search for a distinctive, socialist, communal and truly creative Australia.

At the outbreak of war Vance and Nettie Palmer were on their honeymoon in Brittany after their marriage on 23 May 1914 at Chelsea Chapel. They returned to London towards the end of 1914 . Nettie's lively correspondence with her brother Esmonde during this period reveals some of the difficulties the Palmers faced in their efforts to resolve the conflict of loyalties presented by the demands of war and their continuing commitment to social reform.

Nettie received Esmonde's first alarmed response to her own earlier letter on the war in the middle of November 1914. Only then did she realise how sharply their views differed, especially since Esmonde had intimated that she had turned 'jingo'. Nettie replied that she had been in France when the war began and the country had impressed her deeply. She wrote: 'Sorry dear: to my mind, the country really has about it unmistakeable marks of having lived profoundly in the past ...'. She felt sure that the French involvement in the war was not capitalistic in its motives and maintained that the French had shown restraint, dignity and determination in the face of a German threat. 'I feel sure', she added, 'that this is symptomatic on the part of France, \& that her hands at least are relatively clean. France is a republic, \& feels like it after all. I wish Australia was the same.' Nettie believed that the outbreak of war had demonstrated that 'at this time the Internationale movement is not genuinely \& sufficiently organised, while the Marseillaise one is. That is what we found when the test came'. While the Palmers were sympathetic to France, they had considerable doubts on the merits of British participation in the war. However, despite their Shavian reservations, Nettie felt that since the war had begun ' $I$ 


\section{Dream and Disillusion}

feel that fighting it through is the only way to finish it'. Even so, she strongly denied that Vance had made a jingo of her as Esmonde had suspected. She pointed out that he had been in 'hot water all his life' for not being jingo enough and added: 'He's more of a nationalist than I'll ever be, but not in an Imperialist kind of way. He believes in a patriotism like Ireland's, cherishing idiosyncrasies and liberties'. Moreover, Nettie wrote that Vance believed that the world would be a poor place if there was nothing people cared enough about to defend. ${ }^{2}$

Esmonde was provoked and annoyed by Nettie's letter. At the time he was a member of Frederick Sinclaire's Free Religious Fellowship where he had developed 'much stronger Internationalist views ... '3 Not surprisingly, in his difference with Nettie about the war Esmonde found Nettie's defence of nationalism difficult to understand. Since he could not understand how 'a patriot was diametrically opposed to an Imperialist' he found Vance's claim to be an ardent patriot while at the same time 'anti-jingo', quite 'unintelligible'. In his view patriotism and jingoism differed only in degree: 'Patriotism is only another name for arrogance, murder and cupidity ...' ' He continued angrily:

I don't see any damn use for wanting to divert peoples' energy from real and natural ideals \& even from anti-Capitalism to what seems to me a false, sentimental morbid attempt to get a bit of fun by reminding people that Australia is Australia \& always was, and their duty is to fight everyone else if the engineers of this musky [sic] sentiment think the damnable honour of the country so imperilled ....

Later in the letter Esmonde wrote of patriotism as the 'sentiment of a poor devil who wants something to live for'. He argued that although 'national revivals are as hopeless at present as International Brotherhood', even so, 'while the former is hopelessly out of date \& getting less likely every year, the latter must come ...' '4

It is evident from the views of Sinclaire expressed in Fellowship early in the war that he would have taken Esmonde Higgins's part in the exchange with Nettie. However, many of the conflicts and misunderstandings in their dispute over patriotism had been resolved by the time the Palmers had returned to Australia in the middle of 1915 and Palmer, Esmonde Higgins and Sinclaire later came to share similar attitudes towards the war. Many of their ideas appeared in Sinclaire's magazine Fellowship. Some of them also found their way into Melbourne University. Esmonde Higgins and 
his friend, Guido Baracchi, were both students at the university and were prominent on the university magazine in 1917 . Baracchi's socialist and nationalist convictions will be examined in the course of this chapter.

The first number of Fellowship appeared in August I9I4. In the second number Sinclaire gave his reflections 'On the World at War'. He announced:

We have been infinitely clever and amusing in our criticism of the ideals of the past, but we have failed to discover for ourselves an ideal sufficient to give dignity to our lives, and rescue our culture from the taint of selfishness and frivolousness. ${ }^{5}$

In October he noted: 'What the world needs to-day is not criticism and denial of old beliefs, but help in the acquisition of new and better ones.' ${ }^{6}$ Initially, it seems, Sinclaire was not certain precisely what these new values might be. In September I9I5 he was feeling more certain, having read Hobson's National Guilds which he considered 'by far the most important contribution[s] to Socialist literature that had been made for years'. Sinclaire approved Hobson's criticism of the wage system and declared that in his view, civilisation depended upon the emancipation of the worker, while the present system, like slavery, was based on a denial of the human personality. He praised National Guilds for the humanity of its socialist program as compared with the State Capitalism of the Fabians and he hoped it would attract many socialists who had grown disillusioned with Fabianism.?

Vance Palmer first contributed to Fellowship in the middle of 1916 with a series of three articles on National Guilds. ${ }^{8} \mathrm{He}$ argued that guild socialism emphasised the satisfaction which men could gain from creative work while collectivists, in contrast, sought a utopia where men would work for only short periods 'and spend the rest of the time reading poetry and dancing around the maypole'. ${ }^{9}$ This was a facetious version of the charge he had made against Fabians in the Socialist in 1913. In his second article, Palmer maintained that national guilds had 'not been conceived in any spirit of Utopianism. Rather have they been built on solid earth, taking the present workers' unions as a basis for all reconstruction'. Palmer did not measure the benefits of guild socialism in material terms. In describing the possible effects of industrial democracy he wrote: 'One can only assert that it would liberate a flood of spiritual energy that would make its material advantages seem almost 


\section{Dream and Disillusion}

trivial and irrelevant!'. Palmer, like Sinclaire, believed in the great spiritual resources of ordinary men and hoped that this potential would be recognised and released in the future.

Sinclaire's renewed concern for the regeneration of society was evident in a series of articles titled 'Towards a Living Theology' which first appeared in Fellowship early in 1916. He argued that theology spoke a language remote from that of everyday experience and was often obscure and irrelevant to the needs of ordinary people. He asked:

How is the religious life of to-day to find a language which shall give it natural and fitting expression? There seems to be only one way, and that is to let the imagination play freely upon the most homely and commonplace facts of experience.

Sinclaire hoped for a change in the language of sermons, hymns and religious literature similar to the 'revolution' Wordsworth had brought about in English poetry. The new theology would deal with common experience: 'This living, perennial experience of the individual soul, which renews itself from day to day ... is the impregnable rock on which religion rests. ${ }^{10}$ In a later article Sinclaire maintained that religion should grow more responsive to new sources of spiritual growth, like the 'feeling for nature'. He described this as an essentially religious ideal, but one the churches had virtually ignored. ${ }^{11}$. Sinclaire also felt that 'the passion for social justice' which he considered 'the distinctive spiritual emotion of our time' had also fared badly among the churches. This was a grave indictment from a man who believed that a theology which did not 'recognise to the full the holiness of democratic aspiration' was 'dead beyond the hope of resurrection'. ${ }^{12}$

In May 1916 Palmer followed the lead which Sinclaire had provided in 'Towards a Living Theology' by writing 'Toward a Living Culture'. Just as Sinclaire pictured a new religion freeing itself from the conventions of religious orthodoxy, Palmer envisaged a new culture freeing itself from the conventional classicism of the universities. He dismissed this conventional culture as 'a sterile thing, very proud of its own little monopoly, but not proud in any fierce combative sense'. Palmer noted that when the Age had attacked the classicism of Melbourne University no-one from the Classical Association was prepared to speak for the defence. He surmised that 'its members probably believed in classicism for their own adornment', while thinking 'utilitarianism safer for the herd'; 


\section{War and the Emerging National Culture}

an attitude similar to the one Palmer had censured in the Fabians. He also implied that it was more difficult to write something new than it was to live within a university studying the culture of the past. Of academics he wrote:

Whatever is vital and creative in the life of their own day they ignore or stifle. Therein lies their particular danger. They can bring the authority of their culture ... against anything that is new or novel in ideas, art or social experiment. And so whenever they assert that culture is a storehouse, we have to insist that it is a growth. ${ }^{13}$

In his article Palmer drew a distinction between a stifling official culture and the signs of vitality, creativity, novelty and growth evident in the emerging national culture. It was the type of distinction Edward Carpenter had drawn between competitive society and an emerging socialism.

Palmer's broad generalisations did some injustice to the university. Within the range of Palmer's immediate associates up to 1917 , Nettie Palmer, Bernard O'Dowd, Frederick Sinclaire, Louis and Hilda Esson, Guido Baracchi and Esmonde Higgins were all university educated. Also, in Melbourne University at the time, there were several scholars of the first rank such as Walter Baldwin Spencer, a Fellow of the Royal Society, who wrote excellent pioneering studies of the Australian Aborigines; T.G. Tucker, Professor of Classics, who Blainey described as 'one of the best classicists of the day'; Ernest Scott, Professor of History and Harrison Moore, Professor of Law. All of these men were considered fine scholars and stimulating teachers. ${ }^{14}$

While the imbalance in Palmer's judgment upon the university needs correction his point of view as a creative writer deserves consideration. Palmer believed that the imagination of the creative writer depended on an understanding of the world about him, which required a willingness to take Australian people, their institutions and their prospects seriously. He criticised those who believed that 'nothing in art or life is important unless it comes out of England, Europe, or the remote past' ${ }^{15}$ Palmer believed that the present, and in particular the Australian present, was too often denigrated in a manner that was destructive to the creative process. While Palmer acknowledged his debt to the fine cultural heritage and lively contemporary cultures of England and Europe, he believed that neither their impressive past nor their enlivening 
present achievements could substitute for the lack of creative effort within Australia itself. To deny the importance of a distinctive Australian culture implied that 'our life, our politics, our institutions' were unimportant and 'if so, the same may be said of our personal lives'. He felt there was no reason to scorn the efforts to develop a richer cultural life in Australia. 'Our art may be primitive', he declared, 'but what of that? To improve it and become one with it is the business of culture.'16 There was a new assertiveness about Palmer. Now in his early thirties and supported by men like Sinclaire with values similar to his own, he was growing impatient with apologies about Australian life, and felt less deferential to European cultural attainments.

Ideas similar to Palmer's were also expressed by Professor R.F. Irvine in The Place of the Social Sciences in a Modern University. ${ }^{17}$ Irvine, like Palmer, was attracted by guild socialist ideas and was critical of Australian universities. In his Socialist articles of Ig 3 and in Fellowship, Palmer had mentioned the poverty of debate on issues of social legislation in Australia. In his address to the Melbourne University Association in the following year Professor Irvine declared: 'Nothing strikes visiting economists and sociologists so much as the meagreness of investigation and criticism by Australians of their own social evolution.' ${ }^{18}$ Irvine noted that Australia's reputation as a 'social laboratory of the world' had caused considerable pride among some Australians, but he considered that this achievement was due less to the 'energy of creative thought' than to a 'certain sporting courage in adopting ideas that other countries had hesitated to act upon' and to a 'general weakening ... in Australia of some of the traditional forces of social control'. 18 Irvine's special concern was sociology and its attempts 'to express the nature of the unity we call society'. His advocacy of the study of social sciences in Australian universities could be described as a case for 'living scholarship' which relied on values similar to those endorsed by Sinclaire and Palmer in their articles on 'living theology' and 'living culture'. ${ }^{20}$ Irvine emphasised that the new discipline of sociology expressed a growing awareness of the complex and pervasive interconnecting pattern of social forces in any society. He wrote: "The most we can say is that society, though not an organism, is nevertheless organically connected, held together by pervasive psychical forces.'21 This formulation approaches Orage's idea of a 'sentient unity' and the ideal of a conscious nation which proved so alluring to Sinclaire and Palmer. 


\section{War and the Emerging National Culture}

Irvine considered that the essential characteristics of the sociologist must include an involvement with the structure and spirit of contemporary society, knowledge of the conditions in which ordinary men lived, pursuit of the most fulfilling social values and a concern for creativity, growth and vitality. However, he pointed out that a sociologist of this type would affront the aloof standards of traditional scholarship. Irvine conceded that 'knowledge for the sake of knowledge' could 'shape the taste and strengthen the judgement' but he also argued that it was 'apt to be exclusive and unpractical in spirit'. ${ }^{22}$ Classicism suited 'the leisure class' well as it bestowed an air of distinction and, isolated from 'more vital knowledge', it provided 'a powerful dialectic against change'. ${ }^{23}$ $\mathrm{He}$ added that all too often this concept of culture was accompanied by a 'persistent disregard of the present' which made many universities ignorant of 'present problems' and incapable of illuminating 'the path which men will have to tread tomorrow'. ${ }^{24}$ The mood, the language and the view of society which informed the articles on living theology, living culture and Irvine's living scholarship, was applied to the conscription campaign of 1916 in an article by Sinclaire titled 'The 'Two Australias'. ${ }^{25}$ The article provides an excellent statement of the constellation of values which Sinclaire had come to identify with an 'authentic' Australia. It also describes Sinclaire's intellectual development from a cosmopolitan international socialist to an advocate of 'authentic' Australian values.

Before turning to Sinclaire's article it is necessary to outline very briefly the background of the two conscription referendums. The need for conscription was argued early in the war, particularly by spokesmen for the Universal Service League, an organisation composed largely of middle-class professionals, many of whom were ardent Empire loyalists. The League was formed in New South Wales in September 1915 and branches were soon established in other states. Support for conscription also came from the Australian Natives Association, another largely professional body, which resolved at its annual meeting in March 1916 'to support the Government to utilise the services of every citizen'. ${ }^{26}$ Opinions similar to those of the League and of the A.N.A. were frequently echoed by the daily press and the churches. For W.M. Hughes, who had succeeded Fisher as Prime Minister in October 1915, the question of conscription soon became a matter of urgency, particularly after his return from England at the end of July 1916. After considerable dispute both within and outside the Labor 


\section{Dream and Disillusion}

Party it was resolved that the conscription issue should be decided by a referendum. On 28 October 1916 the conscription proposal was defeated, with New South Wales, Queensland and South Australia voting 'no' and Victoria, Western Australia and Tasmania, 'yes'. The result split the Labor Party. In January 19I 7 Hughes became Prime Minister of the Nationalist Party and in the May I9I7 election he led the Nationalists to a sweeping victory. Six months later Hughes announced a second conscription referendum. On 20 December I9I 7 the referendum was again defeated, but with an increased ' $n o$ ' vote. In the second referendum Victoria joined the original 'no' voting states. ${ }^{27}$

The defeat of conscription has become one of the most thoroughly debated issues in Australian history, yet it needs to be stated that the responses of Sinclaire, Palmer and Wilmot were those of partisans attempting to shape the outcome of the campaigns; not the views of scholars attempting to account for the outcome of the referendums. Sinclaire wrote 'The Two Australias' as a pacifist and a socialist. At the time he was President of the Australian Peace Alliance and on several occasions had spoken against conscription at the Yarra Bank. His interpretation of the conscription campaigns cannot be divorced from his pacifist convictions or his search for a 'living theology'. Sinclaire argued that there were two Australias which roughly encompassed those who voted for conscription and those who voted against. He resisted the argument that those who voted for conscription represented 'the moral backbone of the community'. These he described as the 'respectable' elements of society: 'the Protestant Churches, the Universities, the Capitalist press, and, generally the comfortable classes'. Sinclaire maintained that these institutions and the comfortable classes in general were trying to uphold 'an ethic which is false and a culture which is dead. They have no connection', he argued, 'with any of the vital elements in the life of Australia, and as far as they have an ideal at all, it is that of the English commercial middle class'. Sinclaire went on to assert that 'Australia will never achieve anything, in politics, in literature, in art, in philosophy, so long as she regards herself as a sort of outlandish suburb of England or of Europe'. Derivative culture had no future in Australia: 'every year it is becoming more and more the toy of the idle, the vulgar, and the selfish'. These ideas of cultural vitality largely determined Sinclaire's view of the conscription campaign. He attributed 'the driving force of the campaign against conscription' to a 'dim consciousness' 
of the need for an Australian independence, an independence similar to that which Esson, Palmer and Wilmot had earlier recommended. In each case, and particularly for Esson, Australian independence was an anti-middle-class, anti-suburban ideal. Sinclaire invited his critics 'to turn their eyes from the past to the future, and from Europe to Australia, and to get their feet planted not upon academic abstractions, but upon living experience'. He insisted that recent experience had demonstrated the unreliability of the leaders of society. 'Why not', he asked 'begin to trust the people, and offer them humbly whatever contribution we think ourselves capable of making for the enrichment of their life, and the purifying of their crude but living ideal?'

Sinclaire's ideas in this article resemble Palmer's reflections on the conditions required for creative growth and Orage's statements on national character and the development of a conscious nation. Sinclaire advised Australians to reject their derivative English and European culture because he felt this dependence often led to idleness, vulgarity and selfishness at the expense of honest work, dignity and social conscience. This view was based on the idea that cosmopolitanism led to the dissipation of energy and enthusiasm, whereas creative growth derived from a concentration of the imagination upon the realities of an immediate and familiar world. Sinclaire argued that the anti-conscription vote reflected a 'dim consciousness' in the Australian people of these ideas. He found signs of a 'newer idealism' in Australia, especially among the humbler classes. Indeed, Sinclaire declared that the shape of the future could be discerned in the spirit of the anti-conscription vote. His statements anticipated the emergence of a new, more fully 'Australian' character and community.

In his article 'The Two Australias', Sinclaire used the term 'Australian' to describe qualities and values which he considered would promote a living culture and a spirit of community. Accordingly, his article drew on the notion that the true 'Australian' was not a statistical concept but a figure with some consciousness of a particular historical mission. His article also implied that the process of becoming a 'true Australian' involved a renunciation of middle-class habits of mind. Sinclaire did not write as a man of the people, but as a man humbly prepared to offer himself to the people. $\mathrm{He}$ declared that the need to choose between the two Australias had forced him to renounce his own class. Sinclaire's 'Two Australias' indicates what he opposed as well as what he supported. It was 


\section{Dream and Disillusion}

a protest against the suburban character of Australian life and an attempt to discredit middle-class values. Sinclaire tried to show that the middle classes were outside the mainstream of Australian history. He stressed that the real force for change in Australian society relied upon the co-operation of the creative thinkers who identified with Australian society and the humble people. Together they could shape a new nation. The basis of Sinclaire's optimism had shifted from his pre-war international socialism and cosmopolitanism to a new nationalism in an Australia which had spoken out against the massive destruction of the Great War.

'The Two Australias' is a valuable document in charting the development of Sinclaire's thought and as a statement of what constituted for him, the 'consciousness' of being Australian. Indeed, these are the concerns of his article, rather than an estimate of the actual conscription campaign. The full implications of Sinclaire's views may have been appreciated by only a few. However, his resentment at the bitterness, vilification, coercion and misrepresentation which was a constant feature of the conscription campaign was felt widely in the community. Although the vilification was not one-sided, Sinclaire may have spoken for many 'no' voters when he stated that the 'yes' campaign hardened his resolve to vote 'no'. He declared: ' $I$ was drawn into the campaign in the first place as a protest against the infamous manner in which the Prime Minister was behaving. ${ }^{28}$ Sinclaire insisted that as a pacifist he would have remained silent on the referendum if it had merely been a contest between 'voluntarists' and 'conscriptionists'. By the end of the campaign he felt justified in voting 'no' 'a hundred times over ... and using all my influence to lead others in the same direction' after hearing Hughes's 'lies about the I.W.W., lies about his opponents, spiteful attacks on individuals, hypocritical appeals to religious sentiment he does not feel, successive attempts to coerce and terrorise'. ${ }^{29}$

In February 19I7 Sinclaire followed up his statements on conscription with views on imperialism which bore directly on the issues Vance and Nettie Palmer and Esmonde Higgins had argued about in their exchange of letters in 1914. 'Imperialism', Sinclaire wrote is not the consummation, but the negation, of healthy nationalism. ${ }^{30}$ This statement arose from the belief that imperialism was inextricably bound up with the 'devils of militarism and capitalism'. He felt that all too often it was backed by a semireligious authority, open to abuse by reactionaries. However, 
Sinclaire's chief objection to imperialism was that it impoverished true national sentiments. He insisted that

the centre of every circle is one's own country, whether it is Australia, England or Madagascar. There is nothing jingoistic in this sentiment, any more than there is anything egoistic in the feeling of one's own personal identity .... The implied confession of provincialism makes and keeps us provincial. ${ }^{31}$

Sinclaire suggested that Australians would become proud of their country once they had established their own personal identity. Moreover, he maintained that this national pride would be redeemed from aggression and militarism if the 'conscious' Australian remained aware that his own dignity had been won against a background of colonial subservience.

Sinclaire was also sceptical of the ideals which were alleged to be at stake in the war, or more precisely, he was apprehensive about what had happened to these ideals in time of war. He noted that those who had enlisted to fight felt 'It was not a struggle for commercial supremacy: it was a conflict of ideals. We were fighting ... to preserve the decencies of civilisation. The war was a war between Nietzsche and Christ' ${ }^{32}$ However, Sinclaire believed that 'a more genuine conflict of ideals and cultures' was being waged simultaneously within the nation between the working class and their masters. He felt obliged to serve in this conflict of ideals, as it was here that he had found his allegiances as a 'true' Australian. Sinclaire saw the 'true' Australian and the working man as allies in a battle to preserve the cultural and social future of the Australian nation. It was this association which led him to declare that 'when we say Labour, we practically mean Australia'. Sinclaire later declared that outside the labour movement he could find nothing but 'the mish-mash of Imperialism and the strenuous emulation of British middle-class Philistinism'. ${ }^{33}$

By 1917 , Sinclaire, a man who had been an international socialist with cosmopolitan views, had come to confess having national feeling, even to being a nationalist. Two articles by Esmonde Higgins to Fellowship in 1917 reveal a similar change. ${ }^{34}$ Esmonde outlined a number of atritudes which contributed to the nationalist position. However, the argument which impressed him most was the spiritual malaise which resulted from colonial and cultural dependence. To Esmonde, nationalism now kept open the possibility of an innovating future. This view was in direct contrast to earlier 


\section{Dream and Disillusion}

views expressed in his correspondence with the Palmers. In 1914, Esmonde did not wish to relinquish his attachment to International Socialism for a patriotism he considered militaristic, doomed and futile. Accordingly, he attacked patriotism as out of date and International Socialism held his hopes for a finer future.

At a time when Sinclaire and Palmer were developing their views on living theology, living culture and national sentiment, the case of the Industrial Workers of the World was constantly before the public. Sinclaire and Palmer were alarmed by the treatment of the I.W.W., for it gave them further evidence that the 'servile state' mentality was spreading among the leaders of Australian society. The I.W.W. were a working-class organisation dedicated to the revolutionary overthrow of capitalism. The movement originated in America and offshoots appeared in Australia from I907. In September I9I6 a group of I.W.W. men were charged with treason, but in November 1916 the charge was reduced to conspiracy. The arrests followed consistent I.W.W. opposition to the war, the spread of 'go-slow' tactics among workers and a number of acts of incendiarism which were attributed to the I.W.W. The trial was held in an atmosphere prejudicial to the I.W.W., while some of the evidence brought against them was either of doubtful legal standing or irrelevant to their case. The twelve men arrested were given harsh sentences of five, ten and fifteen years hard labour. ${ }^{35}$ Sinclaire and Palmer both protested about the conduct of the I.W.W. case. Sinclaire wrote 'An Unjust Judgment: Persecution of the I.W.W.' for Fellowship while Palmer sent a letter of protest to the Socialist in which he claimed that the trial expressed some of the more authoritarian and vindictive attitudes in the community. ${ }^{36}$ He feared that 'reactionary ideas' which had 'long hidden like bats in dark unenlightened minds' had once again become a menace to the community. 'It is evident', he warned, 'that something has been let loose that must make all decent people jealous for the preservation of every safeguard that has been won in the past.' With uncharacteristic anger Palmer wrote that Hughes and Pearce had 'shown themselves greedy for power, unscrupulous in the use of it and either ignorant or contemptuous of the fundamental principles of liberty'. He felt that the war, if it had any justification at all, was being fought to discourage such attitudes, not to sanction them.

While Palmer was fearful of what might happen if 'dark unenlightened minds' became more influential in Australian affairs, 


\section{War and the Emerging National Culture}

it was a commentary. on the fluidity of the political situation that he should also see the 1917 strike as a massive revolt against 'servile state' measures and the call to loyalty in time of war. For Palmer, there was no certainty about which social forces were likely to exert an important and lasting effect upon the structure of Australian society and the consciousness of the Australian people. One of the most provocative issues in the I9I 7 strike was the proposal to use the Taylor Card System, a scheme designed to facilitate job costing, but which also enabled close checks to be made on individual workers. ${ }^{37}$ The American, F.W. Taylor, had devised the system and from the middle of 1915 the railway unions of New South Wales opposed its introduction. For their part the Railway Commissioners were disturbed by the spread of I.W.W. influence in the unions in the form of go-slow tactics and in union discussions of the 'scientific strike'. In June 1916 they tried to re-introduce the card system at Randwick, but the men refused to operate it. A new system was introduced in July I9I 7. The step amounted to a breach of agreement (made after a previous attempt to introduce the system) between the Ghief Commissioner and the unions to the effect that job conditions would not be altered until the end of the war, provided the wage claims of the unions were moderate. The engineers decided they would not work with the cards and negotiations between the unions and the Railway Commissioners broke down:

by the night of 2 August, 5,780 railway and tramway men had downed tools. A week later 30,000 men in New South Wales, (including 21,000 railwaymen) were on strike; two weeks later, nearly 50,000 were out; the peak of 69,000 was reached when the strike was five weeks old..$^{\mathbf{8}}$

Palmer wrote an article titled 'Taylor and His Card System' for Fellowship in which he satirised Taylor's scheme and attacked its attempts to reduce the worker to an acceptable servility. ${ }^{39}$ These views were developed more fully in a series of fourteen articles Palmer wrote to the Queensland Worker titled 'Towards Industrial Democracy'.40 Palmer argued that nationalism was the proper basis of industrial democracy. ${ }^{41}$ Nationalism, he insisted, was not the antithesis of Internationalism but the antithesis of Imperialism which provoked antagonism between powerful military governments. Palmer felt that Internationalism meant the cooperation of politically and industrially democratic nations each 


\section{Dream and Disillusion}

of whom had their own national culture which contributed to the diversity of world civilisation. He found factors in Australian life which were in accord with this ideal, one example chosen being the dream of freedom and independence which had inspired many of the early settlers. Palmer also cited Professor Gregory's opinion that the Australian was more idealistic and less romantic than the American. ${ }^{42} \mathrm{He}$ maintained that Australians showed a nice balance between idealism for the future and irony about the present. Palmer believed that this attitude pervaded the best Australian literature and guaranteed any individual Australian character which would be fully equal to the challenge of industrial democracy.

Palmer's first comment on the New South Wales railway strike appeared at the end of August $1917 .^{43} \mathrm{He}$ interpreted the strike not merely as an attempt to improve wages, but as the expression of a feeling among organised railwaymen that 'the time has come for further control over their working conditions'. In this context the merits or demerits of the card system were of less consequence than the attempt to foist the system onto the unions. Palmer believed that the strikers, to their credit, had resisted industrial autocracy. The whole tendency of the card system, he argued, was towards an intensifying efficiency that would turn men into machines. Palmer felt the central issue of the strike was that 'the workers have the right to be responsible partners in industry, and not mere cogs in the great wheel'. Moreover, he warned that a country which followed the principles of the Taylor Card System might well gain wealth 'at the expense of manhood'. With guild socialist forebodings about a trivialised future Palmer insisted that such a country 'would have all its inherent vițality sucked dry in two generations'. The reception of Palmer's articles to the Worker is difficult to determine. However, in the middle of November 1917 Palmer informed Nettie that the Worker's editor had been 'choking me with butter about my articles which have apparently caught on in Q'.44 It may, of course, have been editorial practice to flatter contributors to the paper in the hope of receiving more articles.

Frederick Sinclaire substantially agreed with Palmer's interpretation of the strike. He wrote in Fellowship that the revolt against the card system was a revolt against wage-slavery. 'It is an assertion not of animal wants, but of human rights.' He went on: 'The large principle involved in the strike is ... the principle of industrial democracy.' 45

In his Worker articles Palmer greeted the second defeat of 


\section{War and the Emerging National Culture}

conscription much as Sinclaire had received the first. 'The vote of December 20', he argued 'was largely due to a newly-awakened feeling of nationality.' He maintained that Australians 'believed that, after all, Australia was not the same as Yorkshire, and that its national status and national life would be imperilled by accepting conscription'. Since 'nationality had won' Palmer felt that it was necessary to determine how 'the Labour movement stands in relation to it'. He maintained that there were 'obviously' two sorts of people in Australia. 'One believes that Australia is an individual country, with a particular national character and peculiar problems that have to be worked out in their own way.' These were mostly native born. 'The other sort of people . . have no love of country in the real sense, but are in love with an idea of Imperialism. In spirit they are absentees.' Palmer felt that there was a 'real difference' between these two attitudes and insisted that 'the future of Australia depends on which of the two shall remain uppermost'. Palmer believed that Australian resentment of Imperialist attitudes had slowly given rise to an awareness of distinct nationhood. $\mathrm{He}$ emphasised that this nationalism had a firm basis in reality: 'Nationality is not a theory but a fact and democracy is its natural expression everywhere'. Palmer did not consider that this democratically disposed nationalism was a creation of the labour movement, for he had not experienced over three years of war without feeling the power of Imperial sentiment within labour ranks. However, he believed that it was now vital for the labour movement to cooperate with the new sense of nationalism, to work with it to bring about an abolition of the wage system: 'Labour and democracy', he declared, 'must take the side of nationalism.' 46 This comment was a more cautious version of Sinclaire's statement that 'Labour' and 'Australia' were almost synonymous.

Palmer's advocacy of nationalism in 1917 coincided with propaganda associated with schemes for Imperial Federation which had revived as the need to share the burdens of war grew more pressing. There was strong opposition to the scheme in the labour press, notably in the Australian Worker. In January I9I 7 Henry Boote, editor of the Worker, called Imperial Federation a national danger. 'This country', he declared, 'must advance along original lines. It must create a soul of its own, a brain of its own.' A week later he announced that the 'profound indifference' of Australians to Imperial Federation was 'conclusive evidence of our divine right to be a Nation and not a suburb'. ${ }^{47}$ Palmer made similar objections 


\section{Dream and Disillusion}

in the Queensland Worker. He declared that Imperial Federation would 'land us back in colonialism, with its material retrogression and its spiritual death'. However, while Palmer stressed the 'spiritual dangers' of the scheme he was dubious about its prospects. $\mathrm{He}$ believed that the 'handful of men in our universities, newspaper offices, and other centres of anti-national prejudice' who supported Imperial Federation did not have the ability to solve the complex political difficulties which their proposals involved. ${ }^{48}$ Even so, the issue had a useful propaganda function for it enabled labour and nationalism to be pictured as complementary forces fighting a common enemy. Like Vance Palmer, Esmonde Higgins also deplored Imperial Federation. $\mathrm{He}$ and his friend Henry Minogue argued that the ideas of Imperial Federation circulated in the Round Table took too little account of distinctive Australian responses to domestic and foreign affairs. They claimed that Round Table-ites were 'absentees in sentiment, and think of our country in terms of another part of the world'. They concluded: 'We have heard enough of "New Imperialism"; what about a little "New Nationalism"?'49

During the war guild socialist ideas of the kind expressed by Palmer, Sinclaire and Esmonde Higgins also found their way into the Melbourne University Magazine. The most controversial exponent of guild ideas at the university was the law student Guido Baracchi. In England, in 1914, he read the New Age with enthusiasm and later described the journal as 'the most excellent weekly review in the English language'.50 When the war broke out Baracchi was on the Red Sea on his way back to Australia. On his return, he delivered the prelection for Trinity College under the ambitious title, 'The Last Word in Socialism'. This address was delivered shortly after the publication of National Guilds. Baracchi later made a more momentous statement on guild socialism in the Melbourne University Magazine for May I9 7. His article provoked letters of complaint to the editor of the Argus, embarrassed the Professorial Board and aroused the anger of loyal students, by far the majority at the university, who forced Baracchi into the university pond as a punishment for his outrageous views. Baracchi was advised to redeem himself by enlisting, but he refused. In 1918 he was fined for making statements prejudicial to recruiting and was gaoled for three months. ${ }^{51}$

Baracchi opened his Melbourne University Magazine article titled 'National Guilds: I - Capital and the State' provocatively. He began: 


\section{War and the Emerging National Culture}

The war, whatever the jingos and junkers may tell us, is not primarily our affair. Essentially it is a European war, fought by the Allies against Germany to maintain the balance of European power. And Australia is not Europe. ${ }^{52}$

It was this statement which drew attention, rather than the ideas which provoked it. When he wrote the article, Baracchi was on the magazine committee of the Students' Representative Council. The article was submitted to the censor and passed, but after publication it was drawn to the attention of the Professorial Board. The Board censured Baracchi. The Argus carried a report of the case and letters to the editor appeared from 'Commonsense', 'Loyalty' and the culprit, Guido Baracchi. ${ }^{58}$

'Commonsense' was a father with a son at the war who protested against the university magazine being 'controlled by a committee of students seemingly incompetent to discriminate right from wrong'. He recommended that the committee should be strengthened by those of 'riper judgement', regretted the weak action of the Professorial Board and hoped that the students would act in such a way as to show the 'vigour and loyalty the public expects'. Finally, he hoped that Baracchi would make amends by enlisting. 'Loyalty' described Baracchi's statements as 'grossly disloyal' and felt that the action of the Professorial Board had been too lenient. 'It would be indeed deplorable', he concluded, 'if the loyalty of the University could be for a moment questioned ....' Baracchi wrote: 'Of course the article in question is perfectly compatible with Australian patriotism. In fact, the words complained of were written in defence of this country's good name.' Baracchi's unrepentant and seemingly perverse comment provoked more letters of protest to the Argus. ${ }^{54}$ 'University Student' suggested that Baracchi should be expelled before his ideas corrupted younger students and asked: "Are Baracchi and Mannix and similar agitators to have full reign [sic] to their tongues?' 'Patriot' asked if Baracchi was still enjoying the privileges of being Australian and 'Undergraduate' declared that the 'loyalty to Australia which he professes will be proved only when he dons the khaki ...' '. A patriotism which queried the wisdom of Australians' participation in the war aroused intense annoyance and hostility.

On 21 July 19I7 the Argus carried a sub-leader designed to explain the phenomenon of the student, but more particularly, although he was not named, Baracchi. The argument was that there was a student mind or mentality which extended roughly from the 


\section{Dream and Disillusion}

age of eighteen to thirty. At thirty; Baracchi was just included. The profile was that of the all-knowing student who turned rebel at the lack of opportunity to turn his wisdom to account. The student was always a radical, never a conservative. The Argus was tolerant of the radical student in the abstract - he was entertaining, enthusiastic, provocative - but went on to warn that radicalism in 1917 wore a different face and could not expect tolerance. 'When youths ... go out of their way to ridicule the nation and the Empire ... then they need not be surprised if some severe punishment be inflicted upon them.' The Argus then went on to convert the radical majority in theory to the radical minority in practice, who, far from expressing the student mentality elaborated in the first half of the editorial, were now considered an aberration among the large body of loyal students. Either way Baracchi did not have a case. In a letter to the Argus he wrote dissociating himself from some of the implications of the editorial:

I cannot but assume that the sub-leader in the Argus of Saturday has some reference to me. I must therefore ask you to acquit me of ever having sneered at the Australian soldier. My attitude to the war might be right or wrong; but I pay homage to brave men, whether they be Australian, English, German, or Japanese. ${ }^{55}$

If anything, this reply was more provocative than his earlier one, for there were few people prepared to pay homage to German and Japanese soldiers in Australia in 1917.

Baracchi and his views were clearly anathema to the Argus, a paper which saw unwavering loyalty to the Empire as the most important attribute of patriotic Australians. While Palmer, Sinclaire, Wilmot and Baracchi all saw the defeat of conscription, for example, as a heartening sign of a new national consciousness, the same event was a demoralising blow for the Argus. In January I 9 I 7 an editorial declared that distance from Europe and 'especially from the centre of our Empire, has meant ... a certain isolation and separation of feeling with regard to what is going on near the centre of things'. In 'The Two Australias' Sinclaire thought this same isolation a godsend. 'Men were too far away', the editorial continued, 'to appreciate what was really going on in France.' Indeed: 'The average voter could not grasp the fact that the liberties of Australia were being decided on the fields of France. ${ }^{56}$

There were other clear differences between Baracchi's views and those of the Argus, particularly over the role of the modern 


\section{War and the Emerging National Culture}

state. Whereas the Argus maintained that the Australian nation at war was defending individual liberty against the German conception of the all-powerful state, Baracchi, as a guild socialist, argued that the war against Germany had been used as a reason for subverting liberty in Australia. For Baracchi, the true Australian was a socialist, but the Argus dismissed socialists as 'exotics, intruders, aliens, in the midst of a people quite different from themselves' and invited its readers to contrast the spirit of Christianity with that of Socialism. 'The ideal of Christianity', the paper declared 'is liberty, diversity, initiative, individual character, and responsibility', whereas the socialist ideal is 'the social and industrial and political machine, in which the individual man is but a $\operatorname{cog}$ in a wheel or a screw in a plate'. The Argus continued in a spirit which again recalls Sinclaire's division of the nation into two Australias: 'These two ideals are not only antipathetic; they are even producing warfare in the development of history.' While Baracchi saw the war as a contest between capitalist powers whose leaders were often contemptuous of individual liberty, the Argus wrote of the war as a crusade against a socialist threat to Christianity and liberty. ${ }^{57}$

The attack upon Baracchi, once started by the Argus, was maintained by the students of Melbourne University. In the July I9I 7 issue of the Melbourne University Magazine, the editors noted that Baracchi's article was strongly attacked. They concluded mildly that 'the author's views of Australia's relation to the War did not agree with that of the majority of the community'. The letters of protest were much the same in their general tone and views as those published in the Argus. The real innovation of the students was their physical intimidation of Baracchi. Late in July he was scheduled to speak on 'The Future of Trade Unionism' at a meeting of the Historical Society. Before he reached the lecture theatre he was surrounded by a large group of undergraduates, some of whom hustled him to the lake. According to the Argus report the crush was so great that Baracchi was not pushed into the lake because too many others would have gone in with him. The University Pond was no place to be in the middle of a Melbourne winter. Baracchi was stood up to his boot tops in water. A meeting was later formed, a chairman elected and a resolution was passed which declared that Baracchi should apologise in the next magazine for expressing views which discredited the university. ${ }^{58}$

Baracchi's statements caused problems for the Professorial Board of Melbourne University. The Board considered his case in June 


\section{Dream and Disillusion}

1917 and resolved that he should be called in at the next meeting to answer charges of disloyalty. He was charged with:

Misconduct in having written and published, in The Melbourne University Magazine, words of a nature to induce students and others to refrain from supporting with their efforts the active prosecution of the War, and words which ... are calculated to bring discredit upon students and the University generally. ${ }^{59}$

Baracchi argued that as his article had been passed by the censor he felt justified in publishing it. He added that he had no intention of prejudicing recruiting. Baracchi then withdrew from the meeting and a motion was passed unanimously that he be 'severely censured for misconduct ...' and that 'further misconduct' would be 'dealt with rigorously'. ${ }^{60}$ A letter of Baracchi's to the Argus on 16 July in which he confessed amusement at the attention paid to his humble words by the combined professors of the university, was construed as further misconduct. However, a letter of apology published in the Argus on 23 July was accepted conditionally on a declaration from Baracchi that he was 'a loyal citizen of the British Empire'. Baracchi asked for a definition of a loyal citizen and was told that 'loyalty could be judged only outwardly by actions and that it was in that sense that the term was used by the Board'. Before Baracchi withdrew from the meeting he undertook to give his answer in writing on the following day. Once Baracchi had left, the Board resolved that a refusal to affirm his loyalty warranted expulsion from the university. The minutes record that on the following day Baracchi handed a written statement to the President of the Professorial Board declaring himself to be 'a loyal citizen of the British Empire'. ${ }^{11}$

The August Melbourne University Magazine presented difficulties as to what was to be included and what excluded and according to what pressures or principles. Baracchi was due to continue his second article on guild socialism, but in view of the disturbance caused by his first effort the Board of Management decided that the series would be discontinued. It was also decided that if Baracchi was excluded so should one of the letters censuring his article. This letter was titled 'Jingoes and Junkers' and was contributed by R.G. Menzies, a future Prime Minister. ${ }^{62}$

Menzies and Baracchi were both law students and prominent members of the Melbourne University Historical Society. They knew each other's position and mutually and implacably disagreed with it. Of Baracchi's article Menzies wrote in part: 


\section{War and the Emerging National Culture}

'A connection with the British Empire, on the whole rather tragic'? Can Mr. Baracchi be serious when he writes this? I know that he belongs to a school of thought which proceeds on the assumption that everything written by the orthodox historians is hopelessly wrong, and that the true view of the past and the future is found through the columns of the 'New Age'. But let Mr. Baracchi for once put the 'New Age' and his pleasant little notions on one side, and let him ask himself the question seriously - 'What do we owe to the British Empire?' An antiquated economic system merely? The capitalist merely? The banal bourgeoisie merely? Will Mr. Baracchi come up from his digging in the miry clay, and stand upon some little eminence, whence we may see a goodly landscape, and breathe the fresh air of God's heaven. What do we see? We see Australia a great and free country, ruling herself under British Institutions of liberty, equality and fraternity, but with no bloodshed of the revolution. We see a people of rich heritage, its archives stored with a magnificent literature, the gift of the British race. We see a justice unbought and uncorrupted, the priceless birthright come down from long centuries of British folk most [sic?], and the dashing arms of British freemen. We see a shrill minority waving their arms in the market-place and shrieking their poisoned perjuries to the air - and we see a great people that smiles, and passes on its way. We see a mighty host fighting beneath the banners of truth, and justice, and honour, and all that counts for much in the world's future. Their armour is shining, and their shields are white. Who are they? Listen to the cry that goes fading fast into the derisive silence of eternity - 'These are the Jingoes and the Junkers!' Oh, the tragedy of it all!

Menzies's letter exemplified many of the attitudes which Palmer, Sinclaire and Baracchi hoped the emerging culture would bury. $\mathrm{He}$ testified to a tradition which was underwritten by 'the orthodox historians', the 'rich heritage', the 'stored' archives, the 'long centuries', the 'mighty host'. Generally, his views fitted Palmer's account of those who regarded culture as a 'storehouse' and who used the authority of their culture to stifle anything new in the realm of 'ideas, art and of social experiment'. Menzies stressed the timelessness of certain ideals and their guarantee under the mantle of Empire. For Menzies, the war was a vindication of Britain: 'a nation that stands for the world's best civilisation and the spread of the world's purest religion'. Baracchi's views, argued Menzies, were unworthy of his manhood uttered, as they were, at a time when the Empire was fighting for liberty, equality and fraternity. Menzies came closer to expressing majority undergraduate opinion than Baracchi who was very obviously in a minority. The nature of 


\section{Dream and Disillusion}

his ponding was an expression not only of the size of his opposition, but of the hostility to his views. His type of Australian nationalism was seen to be needlessly offensive, provocative and at the same time, futile.

In 1917 Guido Baracchi endeavoured to put some of his principles into practice outside the university when he joined the Victorian Labour College. The college was formed in the middle of 1917 with the intention of providing working-class education consistent with the controlling ideas of guild socialism. The rationale for the college was that the working class had to be convinced of the need to abolish the wage system and organise for industrial democracy. The Central Labour College in London served as a model of independent working-class education and it was to this model that the founder of the Victorian Labour College, W.P. Earsman, turned. Earsman became secretary of the college, Sinclaire was principal and tutor in literature, Maurice Blackburn, then a guild socialist, was tutor in industrial history and Guido Baracchi, tutor in economics. Earsman and Blackburn were both long-standing members of the Free Religious Fellowship and Baracchi was a close associate of Sinclaire's. Palmer knew all these men well and supported the aims of the college. ${ }^{63}$

One of the issues the college hoped to turn to was the second anti-conscription campaign. Hughes had announced on 7 November that the question of compulsory service would again be put to the people. Three days later a group of people met at the Palmer household in Emerald to discuss the prospect of starting an anticonscription paper. Among those mentioned were Guido Baracchi and W.P. Earsman. Baracchi, responsible for the initial idea of the paper, proposed that it should appear as a Labour College biweekly edited by Palmer. The approval of the Trades Hall Council was sought, for it was considered that the success of the paper was dependent on the backing of the industrial movement. Approval was not given and plans for the paper lapsed. It was decided instead to mount a campaign with leaflets and a speaking tour. The anticonscription leaflets were planned, printed and efficiently distributed in time for the referendum. ${ }^{64}$

The speaking tour was arranged by Earsman. He, along with Sinclaire, Baracchi and the poet, R.H. Long, were the regulars, but as none of them owned a car they had to hire one and a driver to go with it. He was 'thoroughly anti-conscription ... [and] a returned soldier'. They toured Gippsland and the south Gippsland 
areas at weekends. Something of the atmosphere of those times was captured in a recent account of the tours by Guido Baracchi:

We had some very, very, hostile meetings. At one of which we got a whole volley of eggs thrown at us; Sinclaire while he was speaking, dripping from face to foot with egg .... There were others too that were partly hostile but in which we managed to win over a lot of support ... . We had a real case and we worked hard on marshalling our stuff and this speaking tour really went very well because in the cases where the environment was not irreconcilably hostile we managed to develop a lot of support even during the meetings, and this is quite an unusual thing too, but in a way the whole thing was in the melting pot. If the story was a good story and a true story and was manifestly so and was documented well, you got results from this speaking. ${ }^{65}$

In February 1918, Guido Baracchi, described by the Socialist as 'the well known expositer of Guild Socialism' was arrested at the Yarra Bank for making statements prejudicial to recruiting. ${ }^{68}$ His case was an intriguing one. Baracchi spoke under the auspices of the Anti-Conscription Army. In a brief speech he refuted, point by point, the clauses of an extremist leaflet called 'The Anti's Creed', designed to slander those opposed to conscription. In the course of his address he was dragged from his speaker's box and 'escorted by his captors [two plain-clothes constables] to the City watchhouse and locked up'. ${ }^{67}$ The usual procedure of issuing a summons was forgone. At his trial Baracchi was convicted of making statements prejudicial to recruiting and of having attempted to cause disaffection among the civil population. In conducting his own case Baracchi had to point out that two statements attributed to him, namely, ' $I$ believe in murder on the high seas' and ' $I$ believe in the I.W.W.', were merely quoted by him from the leaflet he was refuting. The judge was unimpressed. 'I find both charges proved', he announced. He then declared that had he not considered Baracchi 'sadly deficient in mentality' he would have considered it his duty to gaol him. With patient concern for objectivity he added: 'What you said appears to me to be a lot of silly nonsense, full of vanity, and an overweening craving for notoriety. You appear to be unaccountable for your actions. For that reason' he continued 'I will merely fine you $£ 5^{\circ}$ on each charge ....' He also made Baracchi enter a $\mathcal{f}_{200}$ bond. He defaulted and was given three months' gaol in addition to the fines. ${ }^{68}$ As a concession from the government, Baracchi was released two weeks short of his full 


\section{Dream and Disillusion}

sentence. 'Let us all be duly grateful', Sinclaire wrote in the Socialist, 'for this magnanimous concession of the right of political criticism, and wait hopefully for the next' ${ }^{69}$ Later in 1918 Sinclaire was also found guilty of making statements prejudicial to recruiting, but he chose a fine rather than the uninviting alternative of six months' gaol. ${ }^{70}$

At the university, in the press and in court Guido Baracchi's views were considered subversive, treacherous, perverse. Had Palmer or Sinclaire acted as Baracchi had done it is likely that the reactions would have been similar. During the war these men had become outcasts among the 'comfortable classes': representatives of the professions, the press and the churches. War had intensified their conviction that middle-class life in Australia was morally. bankrupt and the society virtually leaderless. Palmer, Sinclaire, Higgins and Baracchi were drawn into the society of those who by conviction, need or rebelliousness placed radical causes within their own society above loyalty to the Empire at war. Although less of a political activist and radical propagandist, Frank Wilmot formed similar views on the national need during World War I. In the war years Wilmot opposed Imperialist thinking, fought conscription and supported moves to foster a more confident national spirit among Australians. Like Palmer and Esmonde Higgins he contributed to Fellowship. Wilmot reflected the journal's distrust of the leaders of society and he was a sympathetic observer of the labour movement. An examination of Wilmot's poetry reveals the trend of his convictions and his kinship with Palmer and Sinclaire on the nature of war and the need for a national culture.

In December 1916 Wilmot published 'To God: From the Weary Nations', his most important poem to that date, in the Book Lover, a Melbourne literary journal. ${ }^{71}$ In 'To God' Wilmot declared that all men shared guilt for the monstrous destruction of the war:

But the whole import of our guiltiness ${ }^{22}$ was that man had turned away from God and had come to believe in his own power and self-sufficiency.

For Wilmot, war had threatened the guiding genius and special destiny of Western civilisation. The following appeal appeared at the centre of his poem:

Teach us to live as bravely as we died.

Though much is taken, much is still to lose,

War has not consumed Thy sheltering grace; 


\section{War and the Emerging National Culture}

$O$, God, recall Thy peoples ere they bruise

The old unbroken spirit of thy race.

Ere we, who held Thy torch, are doomed to climb

From darks again, condemned to see afar,

From timeless depths of catastrophic slime,

The distant gleam of our forsaken star.

In this poem, Wilmot showed that his awe of Europe had diminished, for he believed that the realities of European civilisation had changed. It was no longer something glorious but unattainable as it had been in 'Minor to Major', but a treacherous civilisation in which human ideals and rich cultural traditions had grown debased by the pursuit of money and power. In 19 Io Wilmot had been oppressed by the belief that his own poor gifts were too trivial in spirit to be called a part of literature; he felt culturally naked in a new nation. In contrast, by 1916 Wilmot maintained in 'To God' that the warring European nations should start rebuilding their values by first gathering together in a 'sinner's brotherhood' to beg forgiveness from God. They could only hope that 'spectre memory' could be erased. By I9I6, Wilmot could come forward as a poet with the plea that God in His mercy would forgive men their overbearing pride. He now maintained that Europe must begin building a future out of the materials of the present, a task which Wilmot considered was similar to that of a young nation like Australia.

Wilmot's development from the minor poet of 'Minor to Major' to the more mature poet of I9r6 represented a growth towards self-assurance and spiritual awareness. Wilmot now believed, in the opening years of the war, that his urge to write poetry and to assert the spirit of man was not only a right, but a necessity if men were to be saved from destruction. He asked:

How can the timid form of Peace emerge

Unless the marshals let the dreamers say?

The minor poet had emerged from a state of cultural subservience to a position of cultural maturity, in which his released spirit allowed him to write more fully, spontaneously and unselfconsciously. Hampering restraints were taken away. In 'To God' the poet suggested that a similar growth in spiritual awareness would come upon men if they could turn against the war. For Wilmot, fighting had brought the realities of commercialism and militarism into the open, and he rejected the future they promised. The poet 


\section{Dream and Disillusion}

experienced a period of profound personal development which seemed to coincide with the historical occasion for a spiritual release of man's energies by the rejection of war.

Two responses to 'To God: From the Weary Nations' are worth noting. The first is a Bulletin review. The reviewer played on the form of Wilmot's address. He commented that while the letter would probably bore God if it reached him, it was more likely that it would lodge in the dead letter office. ${ }^{73}$ The reviewer claimed that he did not grasp what the poem was about but he attributed this to the fact that it was not addressed to him but to God. He noted that if God would only reply, the Bulletin would publish the result. The Bulletin reviewer thus refused to take the poem seriously, implicitly rejecting Wilmot's suggestion that all men were equally guilty before God. To the Bulletin Germany was considered guilty before other nations.

This was also Christopher Brennan's view. At H.H. Champion's invitation, he gave his opinion of 'To God' in a letter to the Book Lover. He dismissed Wilmot's claim that all men had sinned equally by their participation in the war. Brennan maintained that the division was not between pacifism and participation, but between those whose sins were 'human' and the Germans whose sins were extra-human: 'Even if every individual German were as superior to all the rest of us as he thinks himself to be... that consciousness of his superiority ... and the intention into which he translates that belief, would still make him transcendentally evil.' Brennan continued: 'The whole business has been told in pattern, it is the legend of Lucifer.' For Brennan the allies were fighting a war against evil. The Germans embodied that evil and had given themselves 'to be its flesh and bone'. They therefore had to be slain and 'their wives and children starved'. Brennan believed that Wilmot did not expose a crime against God or 'our poor humanity'; but rather revealed the 'sublime and complacent self-righteousness' of pacifism. ${ }^{74}$

After writing 'To God', Wilmot puzzled his friends by writing 'Headsmen to the Light', a poem which expressed the spirit of those committed to the pursuit of justice through war. The Headsmen were pledged to guard the souls of the unborn and assert the triumph of good. The poem first appeared in Birth in January 1917. It was later reprinted in The Australian Poetry Annual for 1920 and the Triad, a Sydney based journal which had supported the war selected it as 'the most notable thing in the collection'. ${ }^{75}$ In writing the poem Wilmot implied that he could understand the hard 


\section{War and the Emerging National Culture}

imperatives which Brennan had declared to be the price of a war against evil, yet it was a price he could not bring himself or others to pay. Wilmot wrote to Percival Serle explaining 'To God' and 'Headsmen to the Light' as the product of different views of the war. He felt that there was considerable evidence for both cases, but none of it was conclusive. After observing all the bitter conflict, protracted debate and argument over the war, Wilmot felt that 'a thing is true only according to the intensity with which you believe in it. If you want to fight', he told Serle 'you should borrow the spirit of 'Headsmen', if you are sick of it and its utter bleeding futility then you must adopt the attitude of 'To God'. ${ }^{76}$ Wilmot's own position was best stated in 'To God', but he remained perplexed as to how he should act upon that belief without intensifying the hatred already generated by the war.

In February 1918, 'The Green Spot' which commemorated the second defeat of conscription appeared in Fellowship. In this poem, Wilmot declared that the rejection of conscription had made Australia a nation destined to speak for the oppressed and the unheard. But he also criticised Australia's leaders during the war:

God's ministers denied her, guardians

Of law forsook her, gentle governors

Forgot their heritage, oppressive banns

Slammed freedom's windy doors.

A later verse expressed the conviction that the people of Europe would recognise that their spiritual hope resided in the people of Australia:

'Mid piled disaster what sure things remain, And in the utterance of their voice made true, Stopped mouths of Europe's millions speak again.

To Wilmot the second rejection of conscription had come as a renewed affirmation of the spirit of man and further evidence for his belief that the courage of the people of Australia would keep hope alive among those in Europe oppressed by the war. Wilmot felt that the defeat of conscription was evidence that a new type of man had spoken at a time when Europeans were dazed, perplexed and incapable of knowing in what manner to express themselves. The poet was proud of his native land and more certain of the necessity for poetry. 


\section{Dream and Disillusion}

As a poet, Wilmot had written sympathetically of aspirations which men like Palmer and Sinclaire had sought to bring nearer to social reality. He had struggled to become a poet and give voice to values that would honour his calling. Although he had criticised Australian writers for their shortcomings he put more real venom into his poem 'Whitewash', dealing with academics and ministers of religion. ${ }^{77}$ Wilmot wrote that when there was hard and agonising work of creation to be done the men of the universities and seminaries turned their attentions elsewhere. Yet, Wilmot believed, it was in such raw, provisional circumstances that new ideas emerged and it was while they were emerging that they most needed sympathetic examination. Between 1910 and 1918 Wilmot came to see the struggle of the poet as a paradigm for the struggle of the people to free themselves from oppression. By 1917 this struggle secmed to have moved out of the realm of rhetoric and into the real world of possible social revolution at home and actual revolution abroad. 


\section{7 \\ Post-war Disillusionment}

In March I9I8 Vance Palmer enlisted in the A.I.F. Katharine Susannah Prichard, in an effort to dissuade him, showed him some of her brother's letters telling of suicidal casualty rates and the extreme burdens shouldered by the Australian troops. These stark warnings were intensified by Alan Prichard's death in Flanders in December 191 $7 .{ }^{1}$ Although Palmer remained determined to enlist, he was a diffident patriot. He conceded that there was a case for war against Germany, yet he was adamantly opposed to compulsory service. He was also unable to forget that his enlistment meant withdrawal from the other war waged between the working people and their masters. His sensitivity on this issue is evident in a letter to Nettie where he indicated that he would rather not meet Sinclaire and other members of the Fellowship when he was in uniform.

Once in the army, Palmer found more to praise than he had expected. He wrote to Nettie of experiences which gave 'meaning to the idea of the army as a guild, or band of brothers'. ${ }^{2}$ In this way, Palmer eased the transition from civilian to soldier. However, Palmer saw no fighting for he disembarked in London on 14 November 1918, three days after the Armistice with Germany was signed. After spending a little over a month in France on mopping up operations, he spent a further five months, most of it in England, some of it in Ireland, awaiting demobilisation. ${ }^{3}$ In London, he had long talks with Louis Esson over the prospect of establishing a national drama in Melbourne. The Pioneer Players, the subject of Chapter 8, originated from these discussions. In Ireland, Palmer talked with George Russell about the importance of 'soil and climate' in moulding national character. In articles to Fellowship, he wrote enthusiastically about the lively intellectual and cultural life of Dublin and the democratic character of Irish life. ${ }^{4}$ Palmer returned to Australia on the troopship Euripides in October I 919 . Immediately after his return he began writing weekly foreign affairs notes for the Advocate, a job he held until the end of October 1920.5

Palmer found post-war Australia disillusioning. He lost his former 


\section{Dream and Disillusion}

confidence that the people's cause would triumph in the battle of the two Australias. Indeed, he felt that conservative money-power and the press had consolidated their strength while the people seemed tired, divided and demoralised having lost their zest for social reform. Palmer wrote some inelegant lines on the subject in his poem 'I914-1918'. He asked:

Why did the sacred flame die so suddenly down?

What made the life song wither upon our lips?

And answered:

Not wounds, not death, not burning towns and ships,

But shadows from behind the battle thrown,

Where evil shapes in Trade's dark courts bred,

Stole forth in safety to despoil the dead. ${ }^{6}$

Palmer feared that Australian democracy had become weaker after the war. He found this a disheartening situation for he feared that the 'true Australian' would be absorbed by his oppressors. In this event, the 'true Australian' would become an endangered species, an anachronism and an outcast in his own society.

Such fears are prominent in an article of Palmer's in 1920, titled 'Undemocratic Democracy'.? Palmer, under the casual disguise of his pseudonym Rann Daly, described how he had once annoyed foreigners by his declarations that Australians 'were the most democratic people under the sun'. The longer he was away from Australia, the more the idea had captivated him. While abroad, he had spoken with pride of the 'mob', by which he meant not 'a noisy crowd, but a collection of level-headed men, linked by certain common ideas of what equality, liberty and independence meant'. However, since his return to Australia he had missed the 'mob' and found instead a 'panting sweating crowd occupied in cheering some politician, or welcoming some prince or general from overseas', This was a striking change. His early image of Australia as a country characterised by space, freedom and maturity of judgment had been replaced by another image, that of an emotionally unstable, claustrophobic and immature society. Palmer wished to escape the 'crowd' and rediscover the older society. He feared that the war might have closed the door on a better Australia, leaving him to cope with a society which had alienated his sympathies. Wilmot, Sinclaire and Esson expressed similar feclings. After the war, they developed a greater respect for the past and a sharper resentment of 


\section{Post-war Disillusionment}

the disorder, falsity and ugliness of their society and the times in which they lived.

Palmer's account of the outcast in his own country is not an unfamiliar one. In the decade before World War I both he and his friends often pictured the Australian artist as a man adrift in an indifferent society. In one of his earliest articles Palmer complained that Australians were uninterested in the representation of their life in art. Similarly, Louis Esson had sneered at the 'Spiritual Sahara' of the Australian suburb while yearning for the life, art and gaiety of Paris; Frederick Sinclaire wrote of the need to redeem Australia from 'outer barbarism' and Frank Wilmot satirised the parochial Australian literary world. Despite these reactions against the Philistinism of their society, each remained optimistic about the prospects for change, for they believed that the mass of men were slowly becoming aware of the newer, juster and freer human order which lay within Australia's making. The young Vance Palmer stated that he pinned his 'faith in the growing consciousness of the masses that Socialism will be to their immediate interest and to the permanent interest of all men'. A decade later, such optimism seemed misplaced. By degrees, 'the war' became both an explanation and a scapegoat for the resulting disappointment. It obscured the vision of a new order as the aim for those gathering social forces which were to have transformed Australian society; it had diverted the energies of the people into destructive channels. They became a people who 'bear the brand of wrecked hopes and loveless toil and sorrow'. ${ }^{8}$ These developments left the artist, the true 'forerunner', in possession of a vision of the good society which he felt would never be realised. He was the bearer of a betrayed ideal in a society grown either deaf to his teaching or too disillusioned to respond to an ideal.

It is evident from an article of Palmer's in Fellowship in $192 \mathrm{I}$ that he believed the common man had been lost to 'suburbia' and the class war. ${ }^{2}$ The city dominated Australian life. 'Such civilisation as we have', he wrote, 'has become urban. Melbourne and Sydney stand for Australia nowadays'. He saw this urbanisation as a distinct change for the worse and argued that if only Australia had developed according to the spirit of the 18 gos "its body would be healthier today and its mind more coherent'. Palmer saw Australia as a body grown unhealthy with neglect: the youth of the nation had receded and middle-age approached. At this stage of his career Palmer's attraction to the I8gos was less obvious than his 


\section{Dream and Disillusion}

aversion to post-war Australia. Indeed, he was decidedly vague about what the I8gos had to offer. Even so, he argued that this earlier decade had distinctive virtues which had been lost, leaving a pale suburban reflection of a once robust people.

In 'Undemocratic Democracy' and in 'Australia's Transformation' Palmer complained that his vision of a democratic Australia had been betrayed. He had pictured a society in which reason, good-will and generosity would ultimately prevail against devious self-interest and oppression. By degrees, men' would create a 'co-operative Commonwealth' which in turn would 'liberate a flood of spiritual energy'. By contrast, the war 'liberated' jingoistic fervour, government by executive power, bitter class conflict and mass emotions. From war there had arisen a disturbingly ugly denial of the peaceful, co-operative and fulfilling new order Palmer had envisaged for Australia. The first impulse was to protect the 'innocent' Australia from the disruptive implications of the war. The argument about the two Australias served this function for it drew a distinction between those who were responsible for the war and those who were not. The former were characterised as outsiders, while the latter were described as the 'true' Australians who had remained loyal to the ideal of 'true' socialism. In this way, Palmer was able to preserve the illusion that rationality and good-will might yet build the new order in Australia, even though he believed that such an ideal had grown more remote in Europe since the war. This was a comforting hope, but it was undemanding psychologically and too simplistic as social analysis. It led Palmer to defend and proclaim, as part of an established national tradition, values which had never been more than vaguely defined and poorly supported.

Although Palmer's affirmation of order and simplicity had its escapist side, it was also an understandable reaction to the strains of the war years and the turbulence of post-war society.

By 1917 the strains of war were telling on supporters and opponents alike. Eruptions of violent emotions were almost day-today realities. In the second volume of his biography of W.M. Hughes, L.F. Fitzhardinge refers to the 'unbridled violence' of the second conscription campaign, describing it as 'more strident, more bitter and even more uninhibited' than the first. ${ }^{10} \mathrm{On}$ a trip to Queensland in I9 I P Palmer declared that he was struck 'more and more by the violence of life in $Q$. Everyone seems to live more violently and have violent opinions and prejudices'. ${ }^{11}$ The venomous spirit of one anti-conscription poster bears him out. It warned 


\section{Post-war Disillusionment}

workers that 'Hughes, the damned little Hun says he will force you to fight, for him .... Let Hughes and his bloody Hunnish friends go to blazes before you put on the soldiers uniform' ${ }^{12}$

In the middle of 1918 Hilda Esson wrote to Nettie Palmer about the effects the war was having upon her. 'I have nerves to-day', she declared. 'I feel that I haven't any illusions left and that fate has played me too many shabby tricks'. She supposed the war was responsible for much of her resentment and referred to 'the terrible curtailment of effort and energy - or rather their diversion into new and useless and uninteresting ways. I suppose we all work harder, but who now can have any joy in work!' She went on: 'At our age those four stark years - and God knows how many more, came just in what should be our most vigorous period'. ${ }^{13}$

Hilda Esson's letter reveals a disturbing sense of waste and futility. She hoped that she could learn to cope with these emotions and perhaps even recover some of her old purpose and joy in work. In a similar manner, Palmer, Wilmot and Sinclaire stressed that the discovery of true nationhood would bring a measure of mental repose. In I92I, Sinclaire affirmed the principle of nationality when he declared that 'little as we are merely Irish or English, still less are we internationalists in the bad cosmopolitan sense of having no roots, no home and no loyalty'. ${ }^{14} \mathrm{He}$ restated his position a year later: "it is possible to hold a middle course between parochialism and cosmopolitanism, and in our opinion, the latter, and not the former danger is the more real in Australia today'. ${ }^{15}$ Sinclaire linked this view of nationality with an affirmation of 'dignity, simplicity, sobriety and sanity', qualities he described as part of an 'authentic spiritual tradition'. ${ }^{16}$ Sinclaire, along with Palmer and Wilmot, argued that involvement in the war represented a betrayal of this 'spiritual tradition' and of the nation. This view had important implications for its adherents. They could remain loyal to their old ideals of nationhood which had been based on a belief in the natural evolution of a socialist society and the integrity of the common people, despite the fact that these ideals had been badly compromised in the war. Alternatively, they could reject their role as advocates for a new society and try to come to terms with the more complex realities of Australia's place in the post-war world. As we shall see from Vance Palmer's poetry, this choice was not easily resolved.

Palmer's poem 'Europe', which appeared in The Camp, represents an affirmative view of the Australian future in the face of the terrible 


\section{Dream and Disillusion}

destruction in Europe. The poem opens with a picture of Europe as death-like and daunting:

Europe is very old,

It has known wars and death,

The live past stirs within the mould,

Yet chill cometh its breath.

The image is one of an old man grown defeated and life-denying. The poem ends with a repudiation of old man Europe:

I will go south and south,

There life has scarce begun,

And lightfoot, with a laugh on its mouth,

Plays butterfly in the sun.

The poet's attitude changed dramatically in his journey from Europe to Australia. He felt free of the dead hand of Europe; cleansed of the disorder, corruption and malaise which had weighed upon his spirit in the old world. He felt that life was less complex in Australia. Indeed, the 'south' was pictured at an early stage of social evolution in which the burdens of European consciousness were unknown and where life still possessed an arcadian innocence.

'Europe' reflected Palmer's experiences on returning to Australia in rgrg. Soon after he had settled down in Melbourne he wrote that many who had recently returned from 'Central Europe' were 'haunted' by the thought that 'under the starvation and stress consequent upon the late war and the Versailles peace, the whole fabric of European civilisation is doomed to dissolve in anarchy'. ${ }^{17}$ Some years after his short stay in France immediately after the war Palmer recalled 'a landscape that looked like the blistered bubbly surface of the dead moon'. He wrote of: 'Shell holes from which the subsoil had been torn and vomited over the earth around; blackened splinters of tree-boles; tangles of rusted barbed-wire; a dirty confusion of mud and metal!' He was chilled by scenes of 'desolation such as had probably never been seen on this green earth before' and he came away wondering how 'that death-blasted area' would ever be made habitable again. ${ }^{18}$ Fears that 'Europe would dissolve into anarchy' helped create the sharp dichotomy between degenerate Europe and promising Australia pictured in 'Europe'. Indeed, such a division seemed more desirable than it had at any other time in the lives of the key figures of this study. Before the war they had tended to regard Europe enviously as a source of ideas, creative 


\section{Post-war Disillusionment}

energy, stimulating artistic movements and individual genius. Although Louis Esson had tried to state a case for Australia's isolation in this period, he was not entirely convincing. Australia still seemed an intellectual backwater far from the magnetic cultural centres of Europe. However, during the war this attitude to Europe altered. Europe became darker and more forbidding in character and Australia's isolation seemed less disturbing, for it appeared that Australia could emerge as a centre of stability in a disordered world.

It must be stressed that this hope was at best a cautious one. In poems like 'The Farmer Remembers the Somme', 'Easter' and 'The Camp', Palmer revealed some of his deeper misgivings about the impact of the war on Australia. The farmer was a man alienated from the homely world he had known. He was cut off from his past, much as Palmer felt cut off from the saner world he remembered before igi4. There could be no real return home for the farmer.

I have returned to these:

The farm, and the kindly Bush, and the young calves lowing;

But all that my mind sees

Is a quaking bog in a mist - stark, snapped trees,

And the dark Somme flowing. ${ }^{19}$

These lines strike a more sombre note than the jauntiness of 'Europe'. Yet, the impossibility of fully restoring the 'kindly Bush' made it the more alluring for the poet.

Frank Wilmot's poem 'Echoes', which was published in Fellowship in August 1918, also dealt with the returning soldier, although the betrayal of the soldier was a more explicit theme in Wilmot's poem than in Palmer's. Wilmot's soldier was disturbed to find the nation distracted from its promising future by internal division or confusion. Australians were:

Murmuring foreign ideas,

Brooding on the Romanoffs, the Syndicates, the Boyne!

Shuddering in echoes of ceaseless war and causeless revolution, Drowned in echoes of reflected troubles. ${ }^{20}$

The poem was a protest against the disturbing complexity of belief in post-war Australia, which Wilmot related to contamination by 'foreign ideas' and 'reflected troubles'. The poet felt that alien and unsettling ideas had perverted the natural simplicity and unself- 


\section{Dream and Disillusion}

consciousness of the nation. Europe was seen as the dark source of this disturbance. At a deeper level the poem was a protest at the doubts, obsessions and fears which the war had introduced into lives which in retrospect seemed innocently happy.

The approach to the war and to what Frank Wilmot called 'the terrible restlessness of the times' in I92I was a crucial issue for Palmer and his colleagues. In an article titled 'National Poetry' Wilmot pointed out the danger to Australian writers in ignoring the world's problems. ${ }^{21} \mathrm{He}$ dismissed most Bulletin poetry as 'the last word in conventional English verse production. It is done to patterns so worn out that they are discarded in the lands of their origin'. Hollowness and escapism dogged those who were proud to hang 'to the well worn skirts of a great tradition'. When Wilmot tried to suggest what should be done for Australian poctry, his tone grew more tentative. He considered it unwise and unworthy 'to deny attempts made by foreign poets towards an individual and national mode of expression'. Having linked experiment, individuality and nationality in this manner he advised Australian poets 'to take the risk of being Australian'. However, Wilmot found it easier to refute bad models than establish new ones. He recommended

A gleam of real independence, a flash of inherent light, some national tone in our word music - little things like these will count for more than the enormous ode of affected nobility written in the calm of a borrowed security.

There was one question Wilmot might well have asked, but did not. What risk was involved in being Australian while the hope persisted that Australia had not only escaped the worst effects of the war, but had retained an innocent detachment from its causes? Palmer, Wilmot and Sinclaire wished to see the war as something external to Australian life and therefore a less pressing danger to their version of the socialist new order. As the scale of the war and the extent of the Australian involvement increased, their position grew more escapist. They failed to analyse the causes of the war and the character, motives and emotions of those who supported it. Instead, they frequently resorted to merely abusive or conspiratorial accounts of social attitudes which diverged from their own, while often assuming that those who held similar views on the war also shared their more general philosophical outlook. In short, their view of Australian society was falsified, for they diminished their opponents and enlarged their supporters. 


\section{Post-war Disillusionment}

It was hardly surprising that they should complain that their society had changed for the worse when the war was over. Paradoxically, the search for a national consciousness that was supposed to broaden and deepen the writer's understanding of his society produced a narrowness of focus and a sweeping distaste for many of the values which influenced the wider society.

By the beginning of the 1920s Palmer was confused about his future as a writer and as a socialist. His problems were compounded by the fact that his views no longer seemed as challenging as he once hoped they would be. Views similar to Palmer's on the need for a national culture were becoming more frequent in the conservative press, while the collapse of the guild socialist movement in the aftermath of World War I and the resurgent interest in Marxism after the Russian Revolution, undermined the plausibility and effectiveness of Palmer's more literary and 'spiritual' interpretation of socialism. The unwelcome proximity of the right, the more aggressive ideological stand of the Marxist left and the disturbing new waves of cultural experiment from Europe increased Palmer's need to find solace and escape in that simpler and more harmonious world which he now increasingly associated with the 1890 os and the bush. Recourse to this line of least resistance in the 1920 s helps explain Palmer's slow development as a writer in the decade following World War I.

The Sydney Morning Herald's reception of The Australian Poetry Annual for 1920 aptly illustrates how acceptable Australian literature had become in a world of literary experiment. The anthology was produced by the Melbourne Literary Club, a group which had been founded in 1916 by Frederick Macartney, Frank Wilmot and Henry Tate. Bernard O'Dowd and Nettie Palmer were among those who served as editors of the club magazine, while Frederick Sinclaire attended and on several occasions addressed club meetings. The Sydney Morning Herald welcomed the Annual:

In an English or American annual of the sort we should find a good deal of vers libre, as well as adventures in futurism, vorticism, and the rest of the 'isms'. But Australian writers eschew such fads and their work gains thereby. ${ }^{22}$

Louis Esson had been greatly 'cheered' by the anthology although he criticised its lack of originality: 'There are no strong ballads, no songs, no simplicity. ${ }^{23}$ Such views would not have been offensive to the Sydney Morning Herald, indeed, judging by its vigorous defence 


\section{Dream and Disillusion}

of the 'bush school' of Australian writers in June I92 I, it would have applauded them. ${ }^{24}$

Like the Sydney Morning Herald, the Argus and its offshoot the Australasian, deplored the experimental nature of modern literature. Yet this supposed cultural decline appeared to give Australia an opportunity of making some creative impact upon a world apparently drained of creativity. A leading article in the Australasian in 1925 stressed that modern man had entered a 'sterile' and 'almost wantonly critical' age, and warned that 'a consciously critical age is seldom creative ... '. These conclusions were based upon 'the capers of vers-libre and splash-and-dash writing on the one hand, and of cubism and similar follies on the other' ${ }^{25}$ 'This was considered the kind of poor stuff which might be expected in a world lacking true writers and artists. Four months earlier a Sydney Morning Herald editorial which examined 'Literary Cycles' declared that there was a 'depression in British letters' ${ }^{26}$ One effect of this view was that European cultural achievements in general, and English culture in particular, now seemed less daunting. With Europe evidently in a muddle over what constituted a sound culture, conservative papers could feel that the Australian task was to reaffirm the tried values of the past.

The Sydney Morning Herald hoped that Australians would place vitality and health above the decadent values which had perverted European culture. In its first Saturday editorial for 1920 the Sydney Morning Herald acquainted the Australian people with the historical mission ahead of them:

From now onwards ... we shall illustrate to the world more clearly than ever whether in our growth and progress we have refreshed and stimulated, or merely exhausted, the vitality of [that] British civilization .... ${ }^{27}$

As the Herald later pointed out, these aims were consistent with the values of a capitalist society, for the 'self-made men of our day' had not won their social and economic rewards at the expense of the community. Rather 'they had the wit to see an opportunity and the enterprise to grasp it, and in doing so they have rendered the community a signal service'. ${ }^{28}$ On the surface, the difference between Palmer's sturdily independent and community-enriching craftsman and the Sydney Morning Herald's sturdily independent and communityenriching capitalist is not great, particularly as both 'ideal types' 
arose from a contrast between the wholesome vitality of Australian man and the growing decadence of the old world.

The Marxist challenge to Palmer's socialism in the years following World War I was not the first of its kind, for there had been selfprofessed Marxists who were critical of the socialism of the Victorian Socialist Party in the years before the war. At this time, Palmer, Esson, Sinclaire and Wilmot had all criticised Marxists and regarded their defection from the party in 1912 as a victory for tolerant socialism. Sinclaire had become editor of the Socialist in this period. However, by 1920 , one of the stalwarts of 'tolerant' socialism, R.S. Ross, complained of the death of the old Victorian Socialist Party. He felt that after the Russian Revolution many socialists had tried 'to storm the citadels of Capital', but he believed that their tactics were ill-advised if only because 'Australia is emphatically not Russia'. ${ }^{29}$ Ross was soon able to report that the Marxists, Guido Baracchi among them, had not taken the party over, yet the victory was much less convincing than it had been in 1912, when the 'old show' were well in command. ${ }^{30}$

The debate between the supporters of the 'old show' and the Marxists also found expression within the Palmer family. Esmonde Higgins was the Marxist while Nettie and Vance remained in the older tradition. As Nettie Palmer took the burden of letter writing from Vance, her point of view has been expressed, although it was one Vance would generally have supported. In September I920 she wrote to Esmonde about an earlier letter in which he had 'thrashed things out about the Materialist conception of History', observing: 'There's a run on Marx just now in several quarters here ....' Nettie expressed surprise that Esmonde had not read Marx earlier, although her comment may have been intended to indicate that Marx had been around for a long time and came as less of a revelation to older hands than it did to enthusiastic youth. She noted that she had read Marx 'a good deal' when she was in Berlin and added that 'Vance was deep in Marx just about your age and he says its almost necessary'. She went on:

Young fellows (pardon the reference to your youth, but I'm hideously old) think so furiously, says V., [Vance] that they feel they must get some definite clue, or else, thinking in all directions at once, they'll simply burn themselves up with thought. ${ }^{31}$

Beyond this service Nettie could find little that was positive to say for Marx and still less for his disciples. She objected to his 'awful 


\section{Dream and Disillusion}

tongue-twisting phrases' and held 'ideology' in particular disdain. Finally she reconciled herself to Esmonde's interest in Marxism with the thought that youth needed something 'diagrammatic and complete as an explanation of phenomena'. Her own illumination at reading Tolstoy, especially What Shall We Do? at the age of eighteen, seemed analogous to her brother's sense of profound enlightenment on reading Marx. ${ }^{32}$

Later in September I920 Nettie wrote to Esmonde, wondering if he would 'go Bolshevik'. ${ }^{33}$ She declared that she would forgive him if he did, knowing that he would not be a slave to the 'altogether mechanical internationalism of it'. The theme of Marxism recurred in the letters from late 1919 through to the end of 1921 . In an early letter Nettie wanted to know the objectives of the Russian Revolution. She inquired about the degree of individual freedom allowed in Russia and asked if the Taylor Card System was used in industry and whether collective action was planned for the production of works of art on the assumption that the individual artist was a bourgeois phenomenon. 'The question all the time is ... what kind of normal life do the communists aim at for everyone?'34

In a further letter from Emerald in January I92 1 she raised Marx's contention that the peasant class was moribund and maintained that neither Guido Baracchi nor Katharine Susannah Prichard was prepared to discuss the issue. She criticised Katharine Prichard's tendency to imagine she was 'exercising herself mentally' when she was 'gulping down Communism emotionally'. Moreover, Nettie found it annoying that Katharine found the question of 'what kind of life was to be considered as normal' in Russia as 'almost indecent'. 'Musn't we ask the aim of a revolution?' Clearly, Marxism was a topic that could arouse anger in people who had once been more generously disposed to each other. This anger rose to the surface again in a letter of September $192 \mathrm{x}$. It was provoked by Esmonde, who had accused Nettie of being cliquey. She replied:

You accept Marxism as being, you say, 'so hugely all embracing,' and you insist that Marxist philosophy can show the relations of all other philosophies. Therefore, by hyperthesis [sic], you can't be accused of a narrow, cliquey point of view, for you've attached yourself to the biggest thing there is (which various people used to give as their reason for going into the war with both hands).

Then, once inside the Marxian philosophy, you find it lifegiving and satisfying. You are content with it as an interpretation of life, and by its guidance you can see, as I said and you said, 


\section{Post-war Disillusionment}

the relations of all other philosophies and place them in perspective. In practice though you place most of them in the dustbox. ${ }^{35}$

There was a growing rift between Nettie's nationalism and Esmonde's internationalism. The Palmers could not see how Australia would be served if they became Marxists. In their view it diverted attention from the analysis of Australian society. Esmonde Higgins saw the problems differently. He felt he was being patronised and responded accordingly. He had stepped down from the 'sliprail' of 1917 to stand behind the barricades in 1921 . The correspondence between Nettie and her brother suggests the divisions and bitterness that now separated those who had worked together with a more united purpose in 1917. However, while Nettie Palmer was quick to point out that Esmonde was in danger of finding ready-made answers to social problems in Marxism, she seemed to have grown less willing to concede that her own views and those of Vance on sound nationhood were often vague and evasive.

The division between Esmonde Higgins and Nettie Palmer over Marxism was repeated between Higgins and Frederick Sinclaire. In a letter to Sinclaire, Esmonde praised Marxism and criticised Orage, the small circulation of the New Age, and guild socialism. ${ }^{36}$ The letter angered Sinclaire. He admitted that, like Esmonde, he could lament the state of the world but he believed 'that the devils by which it is possessed can only be exorcised by the forces of reason and good will'. He hoped that was not a cause for quarrel. Turning to the central issue of the letter, Sinclaire explained that it was not a theoretical difference that turned him away from Marxism, but 'the tone and atmosphere of Marxianism as I have known it'. It was wrong, he agreed, to judge a doctrine by its disciples, but he felt forced to do so. Describing local Marxists, he wrote 'I say of them quite deliberately that even if all their doctrines were absolutely sound in theory, these people could never bring any benefit to the world'. He went on savagely: 'They are eaten up with conceit and ravening intolerance, and the atmosphere of petty intrigue and underhand wire-pulling is the very breath of their being'. He then summed up the Marxists he had known: 'I regard them as pathological specimens ... my point was and is that the majority of the loud mouthed revolutionaries are the scum of the Labour Movement'. Finally, Sinclaire asked Esmonde Higgins: 'It is not essential, is it, that I should reciprocate your opinion of me as a mixture of damned scoundrel and contemptible imbecile?' 


\section{Dream and Disillusion}

There was some truth in Sinclaire's claim that his objection to Marxists in the labour movement was more a conflict of personalities than of theories, although it is not always an easy matter to separate the two. In two articles in the Socialist in 1917 on 'The Abstinence Theory' of capitalism Sinclaire acknowledged his debt to Marx and showed that he approved of his account of how capitalist society had developed. ${ }^{37}$ Sinclaire concluded his articles with a brief estimate of how much the capitalist had taken from the Australian working man in 1915 . This hardly amounts to sophisticated social analysis, but it suggests that Sinclaire may have approved of Marxism as a tool of social analysis in Australia, but regretted the extent to which Marx's terminology had been debased in the aggressive cut and thrust of the labour movement. Even so, Sinclaire described himself as a member of the working class and attacked efforts to bribe the working man to co-operate with his enemy, the capitalist. On this matter Sinclaire was more outspoken than Palmer, Esson or Wilmot. His views were cogently expressed in 'An Open Letter to $\mathrm{Mr}$ W.L. Baillieu, M.L.C.', published in the One Big Union Herald in March 1920. Baillieu had written to the Melbourne Herald outlining certain conciliatory proposals designed to secure industrial peace in Australia. As part of his long reply, Sinclaire wrote:

After putting forward your proposal for shorter hours and bigger profits, you go on to talk about giving the workers a share of industrial responsibility. So you are dimly aware that the objective of Labor is not, as you said a few lines above, a greater share of the flesh-pots of Egypt. On the contrary, the very reason why the Labor movement now inspires you with fear is that the workers are getting more and more conscious of a spiritual objective. They mean to leave the Egyptian bondage of the wage system altogether. You, seeing this and fearing this, seek to propitiate them with a proposal to give them 'responsibility.' The word is good, but not the meaning you give it. You wish to entangle the workers more effectually in the capitalist system by making them 'responsible' to you for the smooth working of the present industrial machine. That is not what Labour seeks, and as a peace proposal it is ludicrous. The responsibility of the workers in the 'new world' will be a responsibility, not to you, but to the community, and it will be responsibility, not for the maintenance of things as they are under your control, but for the efficient working of the new industrial machine, which Labor itself proposes to create .... The Labor movement is the instrument of God and humanity, whose sacred mission it is to accomplish the overthrow of capitalism. 
Despite his confident attack on Baillieu and his class, Sinclaire was despondent about the immediate future of the labour movement and of Australia. In February 1920 he wrote in terms similar to Palmer's about the spinelessness of the Australian community. 'We in Australia have just done welcoming General Birdwood, and we are getting ready to prostrate ourselves before the Prince of Wales' ${ }^{39}$ On a larger scale, Sinclaire declared that since the war the world had entered the 'Dark Ages'. ${ }^{40}$ It was in this spirit of anger and frustration that Sinclaire had defended Orage and the New Age from Esmonde's attacks. However, soon after Sinclaire had received Esmonde's broadside it was announced that Orage was leaving the New Age. ${ }^{41}$ His departure was a further testimony to the fading of old hopes. 'The Great War', Orage wrote in .1926, 'put an end to many things and many ideas; and among the latter was undoubtedly Guild Socialism. We woke from the evil dream shortly after the armistice; and in the horrible light of morning we began to count our losses'. ${ }^{42}$ Locally, the failure of a number of the magazines which had sustained debate during, and in some cases, before the war years, was a symptom of these losses. In July 1920 Australia ceased publication. In August 192 I the Book Lover finished after twenty-two years. In the following year Fellowship and Birth died. In May r923 the Socialist was absorbed by the largely syndicated Union Recorder. Ross's Magazine suffered the same fate six months later.

Politically, a conservative Nationalist Government came to power in December 1922 amid alarmist warnings about the threat of Bolshevism. Similar, but more strident threats, dominated the federal election of 1925 which put Bruce, in coalition with the Country Party, back into power. The anti-union bias of the BrucePage government, the substantial unemployment throughout the r920s, divisions within the labour movement and the advent of the depression further eroded hopes that the labour movement was or could become, 'the instrument of God and humanity'. 


\section{The Pioneer Players}

In the Pioneer Players, Louis Esson hoped to achieve a simple theatre which would express the lives of ordinary Australians. This ideal was shaped by Esson's admiration of folk art and his dislike of intellectual and cosmopolitan drama. He wanted plays which were 'lively, simple, with plenty of colour, non-intellectual, without "middle-class" sentiment and drawing-room ethics."1 The Pioneer Players also sought to honour the search for community, craft and wholeness which had found expression in guild socialism and in Esson's fascination with instinct, landscape and the soil. As it turned out, Louis and Hilda Esson were disappointed with the achievements of the Pioneer Players. 'I admit that what we have actually done', Hilda Esson wrote to Vance Palmer 'is not anything to be very elated about, either in spirit or performance. It was something but so much less than we dreamt it would be.'2 Within two years of his return to Australia Louis Esson was exasperated by the staid provincialism of Melbourne audiences and disturbed by the impact of the silent picture on the theatre. Once again, he entertained doubts about whether the Australian was capable of nationhood. Was he merely a figure content to repeat 'all the popular superstitions from beer to bishops of his fog-bound ancestors' as Sydney Barrett had alleged in The Time is Not Yet Ripe?

In 1916, Louis Esson had left Melbourne for the richer artistic and intellectual life which he hoped awaited him in New York and London. Palmer records that after he was rejected for army service on medical grounds, Esson decided to travel overseas and learn something of developments in drama. ${ }^{3}$ It seems likely that Esson had once again grown dispirited with Australian literary conditions, particularly when his expansive hopes of I9I I and 1912 were not realised by the establishment of an Australian drama. Certainly, he had made an angry swipe at the poor standards of commercial theatre in Australia in November I 914 and had criticised Australian theatre-goers for being too cultivated and 'intellectual' for mere Australian plays. ${ }^{4}$ 


\section{The Pioneer Players}

Once in New York, Esson doubted the wisdom of leaving Australia. Early in 1917 he wrote appreciatively to the Palmers of the authenticity of their life in the Dandenongs and of the contentment it offered. By contrast, he found New York unreal, a city of 'makebelieve'. 'I can't see', he wrote 'that this life is important: it's too artificial, too parasitical, to lead to anything'. ${ }^{5}$ Several months later when Esson had established some literary contacts, he told quite a different story. Australia was once again a cultural desert, while America had emerged as a land of artistic promise for the writer. 'It isn't fair to yourself', he wrote to Palmer 'to get lost in Australia, overwhelmed by young lawyers, grocers, and tailors. Australia, after all, is the place for the duffer or the martyr'. ${ }^{\circ}$

This new mood was also short-lived. By the end of 1917 the Essons were prepared to risk the rather dangerous Atlantic crossing to London. They found London more congenial than New York and soon settled into a life of journalism, theatre going, socialising and serious writing. When Palmer was in London on leave from the A.I.F., he and the Essons spent a good deal of time in each other's company, and discussed literary topics, including the need for a national drama. An attempt was made to produce a bill of Australian plays in London, but the scheme failed for lack of support from theatre managers. At the time, Louis Esson, Vance Palmer, William Moore, Sydney Tomholt and Frank Brown, Louis Esson's half brother, were all in London and all had plays that were ready to be produced.?

After Palmer's visit the Essons recovered something of their old enthusiasm for a national theatre. The prospect of a return to Australia began to excite them. By the end of 1920 Louis Esson's enthusiasm was running very high for he had visited Yeats in November and was greatly encouraged by the whole spirit of their long conversation. He wrote off immediately to Vance Palmer describing what had taken place and told him to take heart from Yeats's encouragement: 'I want you to feel that Yeats' authority would be behind your nationalism, and that you can hit the barren "intellectuals" ... on the head hard.' Yeats had also commented favourably on some of Esson's plays and had encouraged him to believe that

Plays on really national themes, ... help to build a nation in the spiritual sense; while the other type of play, so-called intellectual drama, abstract and cosmopolitan .... will 'shatter a nation'. That is what our scholars fail to realise. ${ }^{8}$ 


\section{Dream and Disillusion}

In the course of his discussion with Yeats, Esson expressed 'some doubt at our being able to achieve originality after only a century's history.... ' ${ }^{\prime}$ This same doubt had bothered Esson when he had first met Yeats and in one form or another it haunted him until his death. He wondered if it was his fate to be a transitional figure cut off from the parent culture, yet unable to find satisfaction in the young and derivative society in which he was reared. When Yeats reassured him about Australian nationality he was glad to accept his judgment. Yeats had noted that the people of Iceland had become a distinct race with their own sagas in less time than Australia had been settled. Evidently, the lesson was that Australia could achieve something comparable. In a Fellowship article Esson added that by national unity Yeats meant 'a spiritual bond . . . that is almost telepathic, as in Ireland to-day'. 10 Sentiment of this kind did not fall on barren ground in a writer who had been influenced by the organic mysticism of Bernard O'Dowd. The lure of a 'spiritual bond' of 'telepathic' strength would have appealed to the lonely and homeless Esson, a man who had never known his father or felt at one with his own country, or totally in accord with the spirit of the modern world. Like Palmer and Sinclaire, Esson nourished thoughts of an ideal world in which the spirit of community was strong and creativity prized.

By 1921 Esson had been away from Australia long enough to forget many of its drawbacks and to again become optimistic about its cultural possibilities. After reading Palmer's The Camp he wrote: 'Some of your pieces gripped me painfully; I wanted to chuck everything and return, for these are my people, too.'11 The 'young lawyers, grocers and tailors' of June 1917 had faded from view and in their place there arose 'my people'. In July 192 I Louis and Hilda Esson and their sons, Hugh and Jim, sailed for Australia on the Demosthenes. They arrived early in September and soon settled near the Palmers in the Dandenongs. Hilda Esson had brought a printing press with her which was set up in a workroom beside the cottage. She intended to bring out small volumes of Australian poetry and essays, while Louis worked on the schemes and plays which would nurture the Pioneer Players.

In the hot summer of $1921-2$ a group of players were brought together and rehearsals were started for Esson's The Battler. Before the season began, however, the Essons' cottage was burnt to the ground and the only existing copies of The Battler were destroyed along with the printing press on which Hilda Esson had just 


\section{The Pioneer Players}

completed the proofs of a book of Palmer's essays. Nevertheless, the Essons managed to rewrite The Battler in time for the season to begin in May 1922. ${ }^{12}$ In the same year they produced Stewart Macky's John Blake (1 o August), Vance Palmer's A Happy Family, (21, 27 September and 4 October) and a bill of five one-act plays by Esson, Palmer, Macky, Gerald Byrne and Ernest O'Ferrall (26, 27 and 28 October). Two plays, Louis Esson's Mother and Son and Alan Mulgan's The Voice of the People were performed in June 1923. They were followed in August by a series of one-act plays by Frank Brown, Katharine Susannah Prichard, Vance Palmer, Stewart Macky and Ernest O'Ferrall. At the Pioneer's last meeting for 1923 in December, plays by Prichard, Wilmot, Esson and Palmer were performed. No plays were produced in 1924 and 1925 . Their last performance, Esson's The Bride of Gospel Place, was in June $1926 .{ }^{13}$

Esson's vision of a popular movement in the theatre which might perform in 'any country, in small towns, etc' was far grander than the actual achievements of the Pioneer Players. ${ }^{14}$ London's diverse theatre world, the inspiring example of the Abbey Theatre Players and personal encouragement from Yeats quickened Esson's imagination; so much so that he overestimated himself and temporarily erased his unhappy memories of Melbourne's cultural failings. Vance Palmer shared Esson's disappointment. He blamed the failings of the Pioneer Players on the coldness of Melbourne audiences and their unwillingness to enter sympathetically into the spirit of the new venture. There were also difficulties in maintaining a group of amateur players on a purely leisure time basis; there was an inadequate supply of new plays and strong competition from silent pictures which were still an exciting novelty. Palmer believed that the 'tide was, for the time being, flowing against the theatre'. ${ }^{15}$

Reports on the reception of the Pioneer Players are too contradictory to confirm this opinion of the theatre. Palmer conceded that the audience for The Battler was 'quite satisfactory' but added that it was 'cool and detached' ${ }^{16}$ Evidently, this coolness escaped the Argus critic who alluded to 'the large a [sic] favourable audience' which attended the play, while the Age noted that The Battler 'drew a large audience and was enthusiastically received'.17 Palmer's disappointing memories may have arisen from the poor audience for one of his own plays, A Happy Family. The reception was unmerited as both the Australasian and the Bulletin considered it a better evening's theatre than the two previous performances by the 


\section{Dream and Disillusion}

Pioneer Players. Indeed, the poor audience prompted the Australasian critic to declare that the Pioneer Players were 'deserving of a much greater measure of support than they have received so far from the public of Melbourne'. ${ }^{18}$ However, with the exception of $A$ Happy Family, the performances of $19^{22}$ seem to have been well attended.

The modest success of the Pioneer Players does not necessarily support Palmer's contention that the times were hostile to the theatre. The most that could be said was that the 'folk-theatre' was not as popular as Esson or Palmer had hoped. Moreover, Palmer's attempt to blame the 'failure' of the Pioneer Players upon the success of the silent picture needs to be understood as the particular expression of his own values. The silent picture had features which in combination displeased Palmer. ${ }^{19}$ They were new, they were popular, they replaced actors in the flesh by more remote images on a screen and they were more often than not American in origin. He felt that the silent picture presented a debased and trivialising view of life which would jeopardise the healthy development of Australia's national character. He readily came to see the silent movie as an alien influence which had helped destroy the promising beginnings of a national theatre. It provided a convenient symbol for the debased spirit of the day. Alan Marshall, recalling the 1920s, expressed similar ideas on the shallowness of Melbourne's urban culture. He described Melburnians as 'victims of advertising and propaganda that was establishing sets of values inimical to the development of culture or the encouragement of high ideals'. Melbourne was 'a city on a bender after emerging from the restraints imposed by war'. ${ }^{20}$ Marshall also described the spread of jazz, the growth of dance halls in the city and the suburbs and the popularity of musical comedy. 'Gladys Moncrieff and Maude Fane' Marshall wrote 'had become images of romance and glamour to factory girls, and clubs devoted to their worship were formed by groups of "Gallery Girls" who clambered up to the gods at each new opening to applaud their appearance.'21

The Australasian theatre critic recorded the musical comedy 'vogue' of 1922, but he also described the following year as an 'exceptional and memorable' one for the legitimate theatre in Melbourne. As Palmer would probably have disputed this opinion ${ }^{22}$ it is instructive to examine briefly the type of theatrical entertainments competing successfully with the Pioneer Players. The most remarkable success of 1922 was Spangles, a musical comedy with a flimsy story and a cast of titillating dancers. Melbourne loved it. 
The city finally farewelled Spangles in November 1922, after a run of thirty weeks which encompassed the entire season of the Pioneer Players. Its 240 successive performances set an Australian record. ${ }^{23}$ Spangles was followed in 1922 and 1923 by a series of musical comedies with titles like $A$ Little Dutch Girl, The Naughty Princess, Mary, Sally, The O'Brien Girl and Little Nellie Kelly which relied on the appeal of diminutive young women whose bright spirits sustained them in a world known to be hard, but far from insupportable to the courageous. This simple philosophy was presented against a background of lavish spectacle which was designed to show how far competing managements were prepared to go in order to entertain and flatter their audiences.

The musical comedies of the early 1920 sere all taken secondhand, generally from English managements. However, the acclaim of London audiences was probably a welcome factor to most Australians. The Australasian theatre critic noted that 'musical comedy and the taste for it are much the same - over the Englishspeaking world, at any rate'. ${ }^{24}$ This did not exclude feelings of national pride, for although the Australasian critic was basically unconcerned about the origin of musical comedies and theatre in Melbourne, he, like the audience he wrote for, could grow enthusiastic about notable achievements by Australians within the theatre. Oscar Ashe was one figure singled out for praise. In 1922 he was a producer of established reputation when he staged Cairo, an extravagant and much heralded production, more notable for stage spectacle than dialogue. The Australasian critic marvelled at its $37^{\circ}$ performers, 270 of whom appeared on stage at the one time in the Bacchanalian scene. He declared proudly that this 'phantasy and transcript of the East', was 'one of those gorgeous creations in which an Australian, . . . has specialised with a splendour and a success surpassing anything else that modern theatrical management has achieved'. ${ }^{25}$

Gladys Moncrieff was an even greater source of local pride. She starred in The Maid of the Mountains which held a Melbourne stage record until the advent of Spangles. When the season opened in September 1922, and the Pioneer Players were performing $A$ Happy Family in the forlorn Temperance Hall, the audience for Gladys Moncrieff at Her Majestys Theatre was large and enthusiastic. The Australasian critic was rapturous in his reviews. Gladys was 'regally beautiful' in The Naughty Princess and beyond praise as Sonia in the Merry Widow. He proudly recorded that after each familiar 


\section{Dream and Disillusion}

number 'the applause came with a crash, and encores of enthusiasm were so frequent that it was long past ordinary closing hours when the curtain finally went down $\ldots,{ }^{26}$

While the success of musical comedy was easy to document, the implications of its success were more difficult to establish. The theatre critic for the Australasian was sometimes critical of the poor dialogue in the lesser musical comedies, particularly those which appeared immediately after the war. Although his preference was for actors rather than entertainers; he was reluctant to suggest that successful musical comedies meant a weakening of interest in more demanding theatre. One correspondent to the Australasian suggested that the war had brought a weakening of social formalities and an independence and liberty to the young which favoured the more daringly flippant musical comedies of the post-war years. $\mathrm{He}$ added that musical comedy 'will always have a big appeal to a community living the open-air life in sunlit scenes, with a happy casual optimism'. Nevertheless he too was confident that good theatre would be well supported, even in Australia. ${ }^{27}$ A leader writer for the Australasian took an altogether sterner view of musical comedy. 'If there is a public', he wrote admonishingly 'that likes to revel in inane vulgarity, and to lap up the witless drivel that passes for dialogue in such performances, there will be managers who will provide what is required' ${ }^{28}$ This was a tame ending for a rebuke which began so promisingly, but his disapproval was certainly clear, even if the social and cultural consequences of 'witless drivel' remained undeclared.

While the Australasian critic was unable to grow despondent about the success of musical comedy, he was also unable to use its success as evidence of a robust theatre and a discriminating audience. He wanted evidence of something more sophisticated in Melbourne theatre-goers than the unsubtle requirements of youths and flappers. He was less concerned at the taste of his own generation who, he declared, had proven their appreciation of fine drama in Melbourne during the 1890 s and early Igoos, than of a younger generation whose response to the finest acting and drama was in his view still untried. ${ }^{29}$. Had the intervening years coarsened the taste of those whose memories did not reach back to the fine drama of the past? Would they be able to appreciate the nuances of the finest acting? The Australasian critic believed that a favourable answer to questions such as these would remove doubts about the future of good theatre in Melbourne. 


\section{The Pioneer Players}

These momentous questions were provoked by J.C. Williamson's plans for Melbourne theatre-goers in 1923, when important figures in English theatre would visit Australia. Lawrence Grossmith and Gertrude Elliott were to begin their season in Melbourne early in the year, while Irene Vanbrugh and Dion Boucicault were scheduled for August. The Australasian critic made several warnings on the importance of these visits. He was particularly anxious that the first season should be well received. With an eye to events later in the year he declared darkly that 'on the eve of some important comedy productions which should resolve doubts as to where Australians really stand in relation to the drama it would be unsettling indeed to find that Mr Lawrence Grossmith ... had but mildly interested Melbourne playgoers' ${ }^{30}$ As events turned out, the Grossmith-Elliott season was a disappointment for the Australasian critic, not because audiences had misbehaved, but because the plays were too contrived and flimsy in their comedy to evoke sustained acting. Indeed, the season was so disappointing that it left our critic 'poisoned for the time by the hookworm of frivolity' ${ }^{31}$

The 'hookworm of frivolity' had also affected another theatre critic. On 7 April r923 an anonymous Argus article titled "Shows" versus Plays - Stage facts and Prospects', examined the state of dramatic art in Melbourne, particularly in relation to the dramatic revival promised by J.C. Williamson's. The writer praised Grossmith and the 'finely natural acting' of Gertrude Elliott but, like the Australasian critic, he was disappointed by the plays offered. In his explanation of this fault he blamed the 'business people of the theatres' who he considered were too ready to make 'a low estimate of the general intelligence of Australian audiences'. There was evidence, he continued, 'that leading players have been advised to broaden their methods, or have chosen to do so because they think that subtleties will not appeal to "the colonies" ". This troubled the Australasian critic throughout the I923 theatre season. He became almost ingratiating in his desire to appreciate the good things made available to Melbourne audiences. His unavoidable criticisms were reluctant and then largely confined to the end of a season. He insisted that the Australian tours were made possible, not by the merits of Australian audiences but by a momentary depression in the English theatre world..$^{32}$

When Irene Vanbrugh and Dion Boucicault arrived, the Australasian critic again grew nervous. 'In the visit of such artists ...' ', he quavered 'Australian theatrical taste is again put to the test'. ${ }^{33}$ 


\section{Dream and Disillusion}

The new season featured plays by Pinero, Milne, Barrie and Laurence Eyre. For the Australasian critic, Pinero's The Second Mrs Tanqueray was the masterpiece of the season. Such a play, he felt, demonstrated a command of dramatic form unsurpassed by more recent dramatists. His delight was the more intense as he was able to remember how, in 1894 , he had seen Dion Boucicault in Melbourne's first performance of the play. The '23 season was crowned by Boucicault's generous tribute to Melbourne theatre-goers. Far from considering his audience vulgar colonials, he declared that 'in England and America alike he had ever maintained that a Melbourne audience was the keenest, the most receptive, the most appreciative he had ever known ... '.94 Overall, the Australasian critic regarded the 1923 season as confirmation of the robust state of the theatre. In the middle of the year he had pointed happily to 'well-filled houses' as evidence that 'the older forms of theatrical effort - which for indentification [sic] may be styled the legitimate - have survived the really serious assault of the pictures'. ${ }^{35}$ In his survey of the theatrical year in 1923 the same critic noted 'a distinct elevation in the calibre and reputation of both players and plays'. ${ }^{36}$ In making these comments he was undoubtedly referring to English plays and English actors. The second-hand nature of almost all these productions did not disturb him, nor, he suspected, did it bother Australian theatre-goers. 'We doubt', he declared roundly, 'whether Australian playgoers - except in quite unusual circumstances - trouble much as to the origin or nationality of their plays provided the play itself satisfies them' ${ }^{37}$ This assured cosmopolitanism was inconsistent with views the Australasian critic had advanced throughout 1923 . In order to test 'Australian theatrical taste' he needed English plays and English actors; preferably welltried plays by dramatists like Pinero and Barrie and performed by equally well-tried actors like Boucicault.

Reports on the state of the theatre in Melbourne during the early I 920 s were obviously coloured by the particular concerns of the critic. The Australasian critic took an indulgent view of most of Melbourne's theatrical offerings. However, memorable performances which for him vindicated the 'Iegitimate', caused Louis Esson gloom about the state of the theatre in Australia. 'How could an Australian company', he once asked indignantly 'interest London by a second-hand representation of 'The Second Mrs. Tanqueray ... ?' Esson insisted that Australia would have to become 'national in regard to drama (at present it is only provincial) before it can 


\section{The Pioneer Players}

become international' ${ }^{38}$ Esson maintained that provincialism stifled judgment and creativity among Australians. It reduced their capacity to select what was valuable from overseas and reject what was trivial or corrupting. The Australasian critic did not show much appreciation of this view, but as the fear of disorderly modernism and the impact of the cinema increased in the r920s, so did those who argued that Australians needed a robust national culture which would protect them from undesirable overseas influences. The alleged 'depression in British letters' has been mentioned in the previous chapter as one factor which stimulated interest in an Australian national culture. Anxiety at the baneful effects of the American film on Australian audiences was another.

In an editorial in 1924, the Australasian summarised two key objections to the silent picture. One was an argument about the general inferiority of the film in comparison to the legitimate theatre: 'drama divorced from literature and from ... the skilled enunciation, and personality of actors who are seen in the flesh and heard with the ear is, at best, an inferior substitute' ${ }^{39}$ A second objection was that films seen in Australia were generally bad. The Australasian leader complained of being 'perpetually regaled with cowboy twaddle, and bosom-heaving, lip-quivering tricks of Los Angeles "close-ups" '. A further leader on "The Vogue of the Movies' early in 1925 , warned that 'American slang . . . threatens to reduce the Australian vernacular to the level of the New York gutter-snipe, and to undo much of the scrupulous teaching of our schools ${ }^{3}{ }^{40}$ The American film was seen as a threat to the continuity of civilised values as these were expressed in literature, drama and education. However, the writer also defended 'Australian vernacular', something he was probably once more inclined to criticise. With the advent of 'cowboy twaddle', ordinary Australian language became a medium for decent and humane values. The door was opening for the acceptance of Australian speech as a medium for literature, drama and education.

By the mid-rg2os the number of American films entering Australia was causing considerable concern. Early in I926 the New South Wales government proposed a tax of $5^{\mathrm{s}}$. in the pound on income derived from the sale and lease of films not manufactured in Australia. The bill passed both houses without amendment. ${ }^{41}$ Even so, this was only a partial expedient. In 1927 an editorial in the Sydney Morning Herald declared that 1618 of a total of 1960 films imported into Australia in 1926 were American. ${ }^{42}$ Later in 


\section{Dream and Disillusion}

the year the bad consequences of the American monopoly were stressed in an article titled 'Ginema Culture: Trade, Education, Art' which pointed out that trade no longer followed the flag but the film. ${ }^{43}$ The American film was seen as a threat to the economic and cultural future of Australians. The implication was that a more national policy in trade, education and art was necessary if Australia was to guarantee its future.

For many observers the silent picture was objectionable because it was American, of poor quality and a pervasive feature of Australian life. An often garrulous and assertive style of advertisement adopted by theatre managements gave further offence to those who preferred restrained advertising, particularly of commodities they disliked. The reader who turned to the amusement columns of the Argus on Saturday 28 October 1922, for example, would have found, if he was thorough, a quietly factual advertisement for a bill of five one-act plays to be performed by the Pioneer Players. It is more probable that his attention would have been drawn to the column where the New Strand Theatre announced in its far more extravagant style that 'The Film Sensation is Here!' The management offered 'A Motion Picture Production Such as the World has Dreamed of for Nearly a Score of Years - A Picture that Will Stand Alone for Many a Day'. The film was The Four Horsemen of the Apocalypse, based on Ibanez's 'world famous novel, read by over 20,000,000 people, and now in its 200th edition'. Finally, the film was described as

The most tremendous drama ever produced, embodying the whirlwind of action, the frenzied love interest and the wonderful characterisation of the most notable story written since the days of Victor Hugo - Enacted by the greatest cast in history comprising more than 125,000 persons, including fifty principals. Production at a cost of $£ 250,000$.

Along with dramatic advertisements in the papers, there were gaudily dressed 'spruikers' who 'strutted up and down before foyers extolling the virtues of the pictures within'. ${ }^{44}$ The Pioneer Players could hardly match this kind of extravagance. Indeed, Louis Esson would no doubt have regarded such display as evidence of the tawdry excesses of commercialism.

Observations about the growing power of the film industry in the I 920 are supported by the increased popularity of films. A Current Affairs Bulletin on the film industry in Australia noted that 


\section{The Pioneer Players}

cinema attendances 'doubled from 67 million in $1919-20$ to 126 million in $1928-29$ on a 20 per cent increase in population'. As might be expected from these figures it was a period of high profits. 'In 1927-28 Union Theatres made $\$ 225,022$ profit, on a paid-up capital of $\$ 600,000$.' However, from the mid-1920s critics of the film industry began to organise their objections. There were those who objected both to the anti-British nature of many American films and, more generally, to the corrupting values they conveyed. A second and related pressure group comprised women's groups who sought stricter censorship, particularly of American films. A third group of indigenous film makers known as The Motion Picture Producers' Association opposed the monopolist hold of Union Theatres and Hoyts over the distribution of films in Australia. These groups, backed by the stirrings of public opinion, were important factors in the government's appointment of a Select Committee in April 1927 to investigate the film industry. ${ }^{45}$ This soon became the Royal Commission on the Moving Picture Industry. After taking evidence from over $25^{\circ}$ witnesses, the commissioners advised, among other things, that awards should be given to Australian films which 'would build up national sentiment'.46

The examination of theatrical performance in Melbourne, particularly in the years 1922 and 1923 , suggests that the American film was not the only form of competition faced by the Pioneer Players. Musical comedy and legitimate theatre were both popular. While most of this material was imported into Australia, there is no sound evidence that a native drama would have been successful if restrictions had been imposed on English or American productions in either the film or the theatre. However, competition from overseas productions persuaded some commentators that a national culture would help protect Australians from the morally corrosive effects of cheap imported culture, particularly the American film. Indeed, hostility to the American film may have helped create an audience for the Pioneer Players. Whatever the composition of their audience, the Pioneer Players were modestly successful, particularly as their plays were staged in a city without a continuous repertory tradition. Accordingly, there were no established local audiences sympathetic to the experimental nature of a small, amateur theatre. Even so, their audiences must have compared with those of the Abbey Theatre Players who staged a short Melbourne season in July 1922. Although the Australasian described the opening night audience as 'very enthusiastic', it was also small.47 Overall, it would be 


\section{Dream and Disillusion}

reasonable to suggest that in their own enthusiasm for a folk theatre the Essons and the Palmers simply overestimated the public interest in Australian drama.

Early in February I924 Nettie Palmer noted in her diary that the Pioneer Players had been wound up. She added cryptically: 'Not enough energetic and leisured people to spare'. ${ }^{48}$ At this time, a disappointed Louis Esson accepted E.J. Brady's invitation to stay at Mallacouta Inlet - the setting of Esson's retreat some twenty years earlier after his first trip overseas. He found the country full of interest and declared that there was 'plenty of material for literature', including 'the interest of the characters, stockmen, hunters, fishers, roadmen, many of them primitive, and some lawless and a few dotty'. ${ }^{49}$ Esson was once again attracted by the literary potential of a world he knew very little about. At the same time he rejected his more familiar surroundings. In February 1924 he wrote of his contempt for Melbourne in a letter to Vance Palmer: 'I don't care for the people, the city, the atmosphere or anything. It is a wowser, bourgeois town, without an idea of any kind, . . .'. He believed that Sydney or Brisbane would have given the Pioneer Players a warmer reception. ${ }^{50}$ After the failure of the Pioneer Players Esson had thoughts of writing a novel which bore directly on his recent experiences: 'It will be an account of the actions and reactions of an artist in a new country ... One of the ideas is that Australia is still an undiscovered country.' Another of his themes drew on the same vein of disappointed hopes evident in Palmer's 'Australia's Transformation' and Wilmot's poem, 'Echoes':

The early republican and radical movement has failed. Do we deserve the country? Or is there such a thing as the spirit of the country independent of the spirit of man? $?^{51}$

Disappointment with the outcome of the Pioneer Players no doubt helped persuade Louis Esson that Australia was a doomed and futile country. However, his mood slowly improved and he was soon hankering for the 'gay life of the city'. He had derived some pleasure from the simple life, but was not equipped to persevere with its privations. In July 1924 Louis Esson told the Palmers that he and Hilda 'ache[d] for companionship. It would be exciting to walk down a street and see the people and the shops'. ${ }^{52}$ Soon afterwards the Essons again returned to Melbourne. From the beginning of 1925 until 1928 Esson wrote a theatre column for the New Triad in which he displayed much of his old verve and wit. Yet those who 


\section{The Pioneer Players}

knew him well, like Stewart Macky, believed that Esson never fully recovered from the disappointing outcome of the Pioneer Players. He wrote less and brooded more, until by the I93os he had acquired the sorrowing air of a man who had failed to realise his dearest ambitions. By the late 1930 , his denunciation of modern civilisation and of the quality of Australian life had grown more intense than it had ever been before. 


\section{The Inter-war Years: National Consciousness Recedes}

In the inter-war years, it was common for writers and social critics to lament that Australia had timidly withdrawn from the pursuit of social reform and lay the blame on the suburban mentality of Australians in the rg20s and 1930s. 'Suburbia' became a convenient label for a society which seemed stagnant and directionless. In turn, the suburbanite was often pictured as a man deprived of his traditional culture and cut off from the land, easy prey to the rootless cosmopolitan life of the city. Behind these views lurked certain disquieting questions. Were men still capable of progressive moral enlightenment or had the war proved these hopes to be futile? Would the search for a higher form of social organisation merely degenerate into sordid bargaining between prevailing interest groups? Would the pursuit of comfort and security progressively deaden moral awareness? If these questions were answered in the positive predictions for the future would have to be pessimistic. For the Palmers, the apparent public indifference to the rise of fascism in Europe and the long, virtually unbroken years of illiberal federal governments at home seemed to confirm the view that the national conscience had grown ominously silent. Yet hope persisted that beneath the tawdry public façade lay a better Australia which would once again grow articulate. This theme had many variations, in particular, the contrast between the cheapness of the city and the simple dignity of the natural world where growth still seemed possible.

In 1925 the Australasian expressed concern over the 'dangerously artificial lives' led by many Australians. It looked to a 'new philosophy of a simpler and saner conception of life' as a cure for the nation's 'psychic maladies'. ${ }^{1}$ Readers of Mary Grant Bruce, Ethel Turner and C.J. Dennis, would have found the Australasian's theme repeated at length, while R.B. Plowman's novel Larapinta took the curative properties of the simple outback life as its central 


\section{The Inter-war Years}

theme. ${ }^{2}$ The subject was Beth Forbes, a frantic young typist of twenty-two: 'one of your modern would-be hard boiled young devils. Rouge, lip-stick, lacquered nails, French heels, and a three-ounce wardrobe.' ${ }^{3}$ But Beth was found to be tubercular. Her doctor diagnosed that she had 'danced and talkied herself to a standstill, and will have to nurse her strength for months'. 'She chose to recuperate on Larapinta station near Alice Springs. In this environment Beth began to change despite herself: 'Her mind no longer moved at a jazz tempo ..... Nature in its primeval simplicity had found out the real Beth and laid upon her its first, though unrecognised, mark'. At the end of the novel she was preparing to marry her girl-friend's brother and was no longer

the hard-bitten shallow thinking excitement monger of the ballroom and the beach. No longer were her eyes hard with sophistication and blatant self-confidence. Love and the mountains had stripped her of the veneer of worthless affectation-of all pretence. ${ }^{6}$

She had been saved from the futility and falsity of city life.

While criticism of the city and suburbia intensified after. World War I, it had also existed before the war, as Louis Esson's writings demonstrate. Esson saw suburban man as a symbol of the conformity which bedevilled a lacklustre and mechanistic age. In his 'Song of the Sububbs', published early in 1906, he lamented the respectability and suffocating ordinariness of the Australian city, where the 'bard in the bar', the 'outer world of sweat and sin' and 'the midnight bust' had been 'lost in a domestic mist':

When the office is locked, the sububb returns to rest in its backyard bowers;

It clasps its leaking hose with joy and sprinkles the cauliflowers;

It eats and drinks and goes to bed at unsensational hours.?

Hugh McKay also deplored the men and women of suburbia. Inspired perhaps by Esson's poem, McKay cautioned a friend in the middle of 1906 against entering a suburban world where:

The Universe leaves for business at 8.3o every morning with a black umbrella ... : the Universe combines tannin-swipes and thrice cooked flesh at its evening meal regularly between 6 and 8.30 every evening: the Universe floods its. 'garden' with a leaky 


\section{Dream and Disillusion}

hose with the utmost suburban precision a little later: and finally the Universe puts out the cat, turns the gas off at the meter, locks all its windows and snores, after a few mechanical sex-bouts with that combined Dairy, Incubator and lust-machine that has the honour to be its wife. ${ }^{8}$

McKay's picture of suburban regularity, trivial domestic ritual, mechanical emotions and sexual monotony was part of a more pervasive fear that modern life had become shallow, featureless and inimical to Heroism and to Art. As Frank Wilmot wrote in November 1905: 'Everything is commonplace now, whatever there may be of dramatic interest in life is not inherent, but is only read into life....' 9

In the poetry of Frank Wilmot and Frederick Macartney, the city often symbolised this commonplace and debased commercial civilisation. They felt that the city impoverished and imprisoned its inhabitants and argued that unless Australian man could resist the city's fatal attraction he would lose an already tenuous affinity for the land in which he lived. In his poem 'New Lamps for Old', Macartney spoke of the Australian's need for 'Strong dreams of earth' and declared:

Nature will not receive us as of old:

We must enfold

The cruder virtues to correct

A knowledge grown too circumspect;

And whatever is the gain

Of cities must be scattered wide as grain,

Till all the grace of life expand

Like sunset colours on ploughed land,

Each cultivated bounty shown

In natural tone;

Tree-roots must break the cities out

Till dwellings figure each spacious field

And the plains to the heart are touched, and healed

Of drought. ${ }^{10}$

Macartney felt that modern man had acquired a barren sophistication. Only with the return of natural man and the dispersal of the cities would the imagination expand to create poetry and song. Vance Palmer had expressed similar sentiments in The Forerunners when he lamented Australia's 'dumb and joyless reapers', its unloved fields, its silent barns and its songless harvests, while in I929 Wilmot wrote in 'Townfolk' of people without 'old world songs' and 'old time fancies'.11 


\section{The Inter-war Years}

In I92I, Vance Palmer described the modern suburb with its 'picture theatres, gramophones, motor cars and villas' as a place 'without pride of ancestry or hope of posterity'.12 'Suburbia' described a society which had neither a sense of tradition nor a spirit of innovation and change. This attitude arose in part from complex emotions of betrayal and disgust following the 'four stark years' of war. Ahead was a grim future, long years of literary endeavour in a country which held the writer in little esteem. This accumulated sense of frustration was projected onto the 'suburb' which seemed to typify all those modern conditions which trivialised and diminished the scope of the artist. America was given similar connotations to the suburb. Palmer claimed that American life was 'too thin and diluted to provide nourishment for its writers', it lacked both "what Lawrence had called the "blood-life" ' and also 'the emotional depth and fulness that comes from centuries of intellectual struggle and achievement'. American life was 'neither really primitive nor really civilised' ${ }^{13}$ Palmer criticised America's: 'thin faith in money, mechanical progress, the future of the country and steam-heat. It repeats its optimistic catchwords in a tireless monologue that has the slightly metallic sound of a gramophone'. ${ }^{14}$ Moreover, Palmer also deplored the rise of cinema and jazz, as did Sinclaire and Esson. 'A world', Sinclaire wrote in 1927, "where culture comes to it through the agency of the cinema and the gramophone will presently be incapable of art' ${ }^{15}$

In 1931, Nettie Palmer described the suburbs of 'most modern cities' as 'formless', 'meaningless' and 'accidental', but pointed out that there were also 'truer suburbs' like the one she had seen in Marburg. There the old city 'wound tightly round and round its hill, with the castle as culmination', while below lay the suburbs 'containing chiefly pensions for the students attending its famous university'. This suburb was gracious, cultivated and enriched by the traditions of the city on the hill. Just as admirable was Bourg-la-Reine, in Paris. Small, cosy and old, it too had the quietness and cultivation which Nettie appreciated. By contrast, and with few exceptions, Nettie Palmer saw Australian suburbia as a 'variegated monster' which lured people away from the centre of the city, without offering 'any positive advantages such as might accrue to little new communities with parks, theatres, and concert halls of their own'.16

In the early r930s, Walter Murdoch also attacked the 'suburban spirit' as an 'everlasting enemy' and a 'peril of which the world 


\section{Dream and Disillusion}

needs to be warned, in season and out of season'. He urged young Australians to be 'worthy of the infinite groanings and travailings of the universe' and not to accept 'the unadventurous, barn-yard sort of life to which modern civilization is apt to condemn us'. $\mathrm{He}$ suggested they should travel, to encounter 'strange peoples and strange ideas', for once oppressed by the suburb 'we degenerate into poor spiritless conforming creatures, making comfortable livings and losing our souls'. ${ }^{17}$ In a later essay, he criticised the spiritual disease of 'respectability' calling it 'the enemy of civilization'. His readers were enjoined to abandon 'the timid virtues, caution, prudence, docility, tameness, discretion' and to adopt independent views. He considered that this was vital if Australians were to live up to their national destiny and not to become 'lifeless automata'. ${ }^{18}$

Much anti-suburban writing was derogatory rather than analytical. 'Suburbia' soon became a convenient explanation for a variety of shortcomings. It enabled the critic to condemn his society without explaining why it had failed to approach the high ideals of nationhood formulated by an earlier generation of writers. Accordingly, Palmer's criticisms of Australian cultural life were often dismissive and somewhat superior. In 1921 , he declared that the Bulletin had been corrupted by a city population 'that goes to cinemas and airs itself on the "Block" ', a comment which merely caricatured the Bulletin readership without demonstrating the deficiencies of the journal's content and style. ${ }^{19}$

Another variant on the anti-suburban theme was to contrast Australians' achievement in the physical field with their failings in other spheres of life. Louis Esson felt that Australians had produced better cricketers than writers. He suggested that 'we could do with some of their qualities in art and literature' since some of them had 'real energy' and 'a touch of genius'.20 Will Dyson, the Australian cartoonist, admitted that Australia may have shown more than its share of physical courage, 'but put it face to face with a new idea and it goes all of a tremble .... In things of the mind we show about as much spirit as a suburban old maid'. Dyson blamed the intellectuals who had failed to speak out on issues of potential importance. As a result, the country had fallen 'into the hands of rich drapers, financial entrepreneurs, newspaper-owners', unworthy people who had forced better Australians to the fringes of their society. Australia had become 'a backwater, a paradise for dull boring mediocrities, a place where the artist as the man with ideas 
could only live on sufferance'. ${ }^{21}$ Several years later Walter Murdoch praised the bravery of Australian explorers, pioneers and soldiers, but found it 'incredible' that Australia 'should show the white feather when it is a question of stepping out boldly down the road of social change; incredible that we should continue to show a lack of faith in ourselves, in our fellow countrymen, in our star'. ${ }^{22}$

Feelings of frustration and disillusionment seemed to deepen during the 1920s and I930s. Frederick Sinclaire gradually became more pessimistic, abandoning his faith in moral progress. In 1927 he declared that 'our wealth of mechanical resource is accompanied by a spiritual poverty which is the more appalling because of the complacency with which we either ignore it, or even pride ourselves on it'. ${ }^{23} \mathrm{He}$ had also grown to distrust the effects of democratic prejudices on Australian literature, particularly when it showed 'what is taken to be the mark of democracy ... a disregard for form, a tendency towards roughness, loudness and violence and an impatience of restraint and reticence'. ${ }^{24}$ In 1942 , he told a radio audience: 'We of my generation began life with a comfortable feeling that ... the face of mankind was set firmly towards the light'. His generation was confident in 'the great law of Progress'. ${ }^{25}$ But he no longer held such views. World War I had disturbed him profoundly, leaving him demoralised and offended in a post-war world. During the rg2os he continued to put his views to the Free Religious Fellowship and gave W.E.A. lectures, but he was a far less prominent figure in Melbourne than he had been before the war. ${ }^{26}$ He had lost much of the energy that had made him well known in the Victorian Socialist Party. After a period in Perth in the late 1920s, he was appointed Professor of English at Canterbury College, Christchurch, where he 'showed his old fire only occasionally'. ${ }^{27} \mathrm{He}$ was frustrated by a syllabus which he considered often tedious and irrelevant but he was largely unsuccessful in his efforts to persuade the Academic Board and the Senate to accept reforms. ${ }^{28}$ During this period Sinclaire wrote for the Christchurch Press and for Tomorrow, an independent weekly somewhat in the tradition of the New Age and Fellowship. In his last years, he was a prematurely aged man given to long periods of depression. The First World War defeated many of his hopes: the second seemed to crush his spirit. He died in ig54.

Frank Wilmot, like Sinclaire, also grew more disillusioned in the 1920 and 1930 s until his death in February $1942 .{ }^{29}$ In these years Wilmot's poetry grew tougher and more direct. Hopes which 


\section{Dream and Disillusion}

had once stirred him were discarded along with some of the more lushly poetic language and sentiment which had recurred in his earlier poetry. Faith in the capacity of men to shape their destiny to better ends faded as did belief in the prophetic power of the poet. In 'The Victorian Markets Recollected in Tranquility', the poet who had turned from valiant lords and grand historical occasions to record 'the lost, the forgotten, the left-unsaid', ${ }^{30}$ found only suffering and futility. Wilmot did not discover a meaningful saga in which the common people were the chief actors and the poet their companion. Instead he found:

A force that throngs the by-ways and the streets

A dark, enormous influence that pours

Its passion through the light and vainly beats

On spired churches and closed college doors.

In love - the jealous pistol and the 'jug,'

In hate - the bottle-swinger and the thug,

In peace - some rows of figures and a graph,

In war - a motto on a cenotaph. ${ }^{31}$

Louis Esson was to become even more disillusioned than Sinclaire and Wilmot. In his letters to the Palmers it is evident that during the I920s he felt discouraged from writing and impatient with Australia. The re-election of the Bruce-Page coalition in 1925 'disappointed' him and he supposed that 'conditions in Australia must be so generally tolerable that people have no desire to risk a change'. He was surprised that Queensland had become so conservative and wrote of how he had once 'looked to the bush workers, shearers and others, as the men most likely to represent the national spirit. Lawson always looked to these men as the real Australians. Now they seem to have become little cockies, thinking themselves ... big cockies'. ${ }^{32}$ By the 1940s Esson even doubted the value of putting his plays into some order. 'Why labour', he asked Dymphna Cusack, 'over something that nobody wants and I doubt if I want myself, six or seven long plays and six or seven short, probably out of date and with little meaning to the world as we know it today?'33 Esson later explained his outlook upon the world at greater length:

This is a difficult period, too difficult and confused for me; and fortunate indeed are they who can strictly meditate the muse, however thankless. I'm not enthusiastic about the New Age, or what I fancy will be the New Age, which is likely to emerge from the present struggle. I think I can say without boasting 
that I knew the doctrines of Marxist Communism forty years ago and was unable to accept them, although $I$ believed in what used to be called the anarchistic communism of William Morris .... The tendency of Capitalism, in its advanced State, as in America, is towards the concentration of power in smaller and smaller groups, as can be seen in the development of trusts and combines, a tendency carried still further in Russia by the creation of an all-powerful State .... I hate America and all its ways and I don't think I'd like modern Germany or Russia either. What I really hate is the unification and mechanization of life, mass-production factories, blocks of workers' flats, picturetheatres, chain-stores, Hollywood music, herd psychology and other manifestations of as ugly and uninteresting a civilization as the world has yet endured .... ${ }^{34}$

Moreover, Esson was unable to derive any reassurance from the Australian situation. He found no sustaining 'legend of the nineties' and could not anticipate a bright future, however remote:

I've made the discovery that we have a kind of inverted snobbery in Australia, a hatred of the classic and a glorification of the mediocre, and the notion that crudity is a sign of vigour and illiteracy of bold originality. We are still a nation of Barbarians. ${ }^{35}$

Esson's last letter to Dymphna Gusack, in November 1943, three weeks before his death, indicates that the optimism he had once shown had disappeared entirely. $\mathrm{He}$ 'had lost faith and interest in reformers' and 'was shocked at the loose optimism of public men with slogans more suitable for pushing salesmen than for statesmen'. He agreed with Gilbert Murray's statement that artists and scholars had a duty to 'keep alive intellectual and artistic culture' and to see that this culture was 'not swamped by floods of mere passing fancies or by the arrogance of the common man in a century which he claims as his'. Esson deplored the twentieth century, but he also repudiated the idea that there had been any 'golden age' in the past. ${ }^{36}$ Hugh Esson considered that his father had never really come to terms with World War I and had always felt ill at ease in the post-war world. ${ }^{37}$ It is certainly the case that most of Louis Esson's plays were conceived before the war and that by the end of his life he felt that his work was dated and irrelevant to the Australia of the r93os and early I94os.

The Palmers remained active writers, critics and liberal reformers throughout the r930s. They spent almost two years in Europe in 1935 and 1936 and were in Barcelona at the outbreak of the Spanish Civil War. On their return to Australia in September $193^{6}$ 


\section{Dream and Disillusion}

they became committed advocates of the republican cause in Spain and opponents of fascism. At this time their eldest daughter, Aileen, was serving with the first British Medical Unit that went to Spain, where she remained until May $1938 .^{38}$ It is evident from Nettie Palmer's journal that after their period in Europe; the Palmers were acutely embarrassed by the survival of a government which actively suppressed knowledge of political and cultural developments in Europe. Isolation had not bred innovation, but insularity. In their opposition to censorship and fascism and their support for, civil liberties, the Palmers were able to draw upon arguments they had encountered before World War I, a continuity in their thinking which has often been overlooked. Their opposition to censorship was evident at the outbreak of World War I when Nettie Palmer wrote from London that she and Vance felt 'horribly ashamed of the Australian censorship and of the Australians for submitting to it'. She criticised the extent to which 'mere opinion' was censored and wished that 'the wowsers could see some of Shaw's speeches and articles, that get printed even in the most conservative papers here'. ${ }^{39}$ The Palmers deplored Australian censorship throughout the war. When the armistice was signed Vance criticised the continuation of the War Precautions. Act and warned that liberty was in danger in a community where 'a lot of people have got used to regulating the lives of others' ${ }^{40}$ His fears for the future are expressed in The Camp:

By whom shall the new world be planned?

O grim darkened huts of iron and gravelled parade!

In your image will it be made?

Will your spirit, your system, your word

guide the artisan's hand?

Will we whom you moulded to pattern by precept and rod Revere as god? ${ }^{41}$

The poem evokes the menace of the servile state, a fear of Palmer's which was to grow more disturbing during the r 930 s as censorship became more rigorous.

The conservative Bruce-Page government initiated an attempt to introduce systematic censorship of literature in $1929 .{ }^{42}$ This continued under the Scullin Labor Government and was intensified by the United Australia Party. The fear of social disorder, which had remained lively throughout the 1920 s with popular concern over the spread of 'Bolshevism', grew more acute with the onset 


\section{The Inter-war Years}

of the depression. More people thought it necessary to protect an already unsettled community from morally subversive or inflammatory literature. Some of this concern was directed at war novels with pacifist sentiments which had begun to be published during the late I920s. ${ }^{43}$ In March 1930 Major-General Sir John Gellibrand criticised Remarque, Graves and other war novelists for misleading the public over the nature of the war.44 Sir Ian Hamilton, who had been supreme commander of the Allied Dardanelles forces, also criticised war novels. He told an English audience that the Empire had made wonderful sacrifices for the Motherland but that the women of the Empire would 'refuse to do so again if they thought that their menfolk risked demoralisation as well as disablement'. ${ }^{45}$ To these men, the war novelists seemed to picture the older ideals of duty, sacrifice and loyalty as only masks which had concealed cheap motives, low viciousness or grotesque confusion. Within three weeks of Anzac Day. 1930, the New South Wales government prohibited the sale of All Quiet on the Western Front which had been on sale for several months after it had been passed by the Federal Censor. ${ }^{46}$ However, more covert forms of censorship had been operating during this period. In July 1929 , Nettie Palmer noted in her diary that the Argus had not reviewed the novel as it was considered 'indecent', an opinion she did not share. ${ }^{47}$

In the harsh light of the depression, the civilised values for which the soldier was supposed to have fought in the opening years of the war seemed rare at a time when the unemployed, many of whom were old diggers rigged out in army surplus, looked for work among their own people. George Johnston has described the scene:

One would see the shabby figures shambling along the suburban streets, carrying a loaf of bread and in a cloth bicycle-bag their meagre handout from the Sustenance Depot of tea and sugar and flour and potatoes, and a wisp of tobacco. Or there would be a queue of men the length of a block, most of them in the ill-fitting, shameful black, in apathetic competition for half a dozen casual jobs. As the situation grew worse desperate attempts were made towards alleviation, and the 'black coats' moved then in the more regimented bands of the 'sustenance-workers' and you would see them with their brooms and picks and shovels and council tip-drays working in slovenly unison on pointless municipal projects. ${ }^{48}$

In this disturbing climate; the new realism of Remarque, Graves and Hemingway offended many who preferred to remember the 


\section{Dream and Disillusion}

war as a noble cause well suited to patriotic editorials, sermons and after-dinner speeches. The offence was compounded when the young began to challenge and sometimes openly reject the patriotic ideal of a young courageous people who had proved their nationhood in war.

War novels were not the only books to be condemned by the censors. One of the most controversial novels to be banned during the I 93 os was Norman Lindsay's Red Heap. By r $93^{\circ}$ Lindsay was a veteran of the anti-wowser campaign. Many of those who had been shocked by his robust and voluptuous nudes were prepared to fear the worst from a Lindsay novel. In May r $93^{\circ}$ Red Heap was banned 'on the ground that certain passages were indecent or obscene' and it was pointed out in the House of Representatives that 'the novel contained serious reflections on the morality of a certain country community in Victoria ${ }^{9}{ }^{49}$ Nettie Palmer wrote a letter protesting against the censorship of the novel, although she was not enthusiastic about it or its author. Several fellow writers, including Furnley Maurice, signed the letter, which was published in both the Age and the Herald, but ignored by the Argus. ${ }^{50}$

With the passing of the Labor Government and the subsequent appointment of Lieutenant-Golonel T.W. White as Minister of Trade and Customs in December 1933, official censorship entered a new and more disturbing phase when works of a more political character were banned. ${ }^{51}$ At the end of 1934, the Book Censorship Abolition League was formed in Sinclaire's old church at Eastern Hill. Its spokesmen maintained that books circulating in England should be allowed into Australia. W. Macmahon Ball was president, Margaret Kemp was secretary and the Palmers and Louis Esson were among the early members. In February 1935, Margaret Kemp reported that sixty-six political books had been banned before December 1933: another seventy-nine had been banned between then and 26 October 1934, while another twelve had been banned between that date and 9 January $1935 .^{52}$ Among the books excluded were Bukharin's A.B.C. of Communism, R. Palme Dutt's Fascism and the Social Revolution, and Allen Hutt's Condition of the Working Class in Britain, as well as a number of Lenin's works. This state of affairs drew sharp protests from a number of eminent men. Professor Giblin, Ritchie Professor of Economics at Melbourne University, deplored the workings of censorship. 'No people', he declared, 'could embark on the adventure of freedom with so little risk. Instead we are hiding ourselves in the deepest funk-hole'. ${ }^{33}$ Referring to 
Australia, Jonathan Cape, the publisher, warned that unless public opinion grew more alert, the time would come when 'Britishers will be governed by a junta of narrow-minded dictatorial people constituting a form of intellectual Fascism'. ${ }^{54}$

The interest raised by the issue of censorship was demonstrated by the enormous crowd which attended a debate 'That Political Censorship be Abolished'. Three thousand people crowded into the Melbourne Town Hall and some were turned away. 'Never before in the history of debating in Australia', boasted the Star, which had sponsored the debate, 'has such a large gathering listened to the views of eminent speakers on a topical controversial subject'. ${ }^{55}$ Later in May 1935, a protest meeting against censorship almost filled the Melbourne Town Hall where Frank Wilmot and Brian Fitzpatrick were among the speakers. ${ }^{56}$

There can be little doubt that the drive against censorship received a great stimulus from the Federal Government's inept attempts to prevent the Czechoslovakian writer, Egon Kisch, from entering the country. ${ }^{57}$ Kisch was invited to Australia by the Movement Against War and Fascism which timed his visit to coincide with imperial defence discussions and the official celebrations of Melbourne's centenary in November 1934. The visit emerged as a test of United Front policies aimed at broadening the appeal of the Communist Party, especially in its opposition to fascism. The conservative United Australia Party Government resorted to repressive censorship and scare tactics about a communist bogey to control these influences, but the attempt was largely unsuccessful. In his foreword to Kisch's Australian Landfall, A.T. Yarwood wrote that the 'federal government's actions, unless viewed as an extremely subtle attempt to give aid and credit to the Movement Against War and Fascism, may be fairly condemned as unwise in policy and inept in execution'. ${ }^{58}$ In the period from. I6 November 1934 to I I March 1935 Kisch addressed dozens of meetings throughout Australia. He drew large crowds, including a Domain meeting of 5000, and became headline news. Trade unions, writers and academics protested against his prohibition. Vance Palmer and Louis Esson were among them. Palmer declared:

We have lately grown almost accustomed to arbitrary acts by the Federal Government; but this attempt to exclude Herr Kisch from Australia is even more serious than the exercise, for instance, of a stupid and half-witted censorship over books .... This is a deliberate act of those who are, for the moment, high 


\section{Dream and Disillusion}

in authority, and it is an insult, not only to Herr Kisch but to every Australian citizen of intelligence. Is our democracy going to sink to a Government of sheep by yokels, or are we going to insist on civilised standards in administration - freedom in the pursuit of truth and in the interchange of ideas?59

It is clear from these comments that the indignity of being Australian was at least as strongly felt in the 1930 s as it had been in 1914 when Nettie Palmer said she was ashamed of Australian censorship. The acts of the Lyons Government made Australia appear as a narrow, parochial and rigid society, grimly determined to uphold its dull respectability.

The Palmers did not abandon their attacks on censorship when they left for Paris in March 1935. Nettie Palmer and Christina Stead were Australian delegates to the Congress of Writers for the Defence of Gulture which met in Paris in June 1935. In their address to the Congress they declared that the 'reactionary government' of Australia, taking advantage of the country's isolation, had banned books 'which would keep Australians in touch with progressive English and European thought', and they demanded that 'the worth and legality of books should be judged by Australian literary leaders and not, as at present, by politicians'. As delegates they went on to describe the campaign against censorship and the Congress was urged to send protests to the Lyons Government. ${ }^{60}$

During their stay in Europe, the Palmers became more conscious of the conservatism of the United Australia Party Government but were not persuaded that fascists were a direct menace to Australian society. Nettie maintained that the 'danger of fascism everywhere in Europe' was probably difficult to appreciate from Australia. She noted the rise and decline of the New Guard, but declared that in general 'our anti-Labour-people are merely the reactionary governments'. ${ }^{61}$ Even so, the Palmers did not see fascism as a development confined to Europe and peculiar to the r93os. As with censorship they drew similarities between fascism and the servile state. They were not alone in doing so. In I940 George Orwell described Belloc's The Servile. State as a book which 'foretold with astonishing accuracy' the rise of totalitarianism, and five years later Margaret Cole agreed that the servile state was a 'good enough description of the social ideal of Fascism'. ${ }^{62}$ However, the collapse of the guild socialist movement which, in part, had sought to combat the servile state, left the Palmers with no movement to turn to with a similar social philosophy. Instead they supported 


\section{The. Inter-war Years}

small minority causes which emerged in the r93os like the Book Censorship Abolition League and the Council for Civil Liberties. On their return to Australia from Spain the Palmers, Nettie in particular, became absorbed in the Spanish cause through the Spanish Relief Committee and the Joint Spanish Aid Council. If anything, the Palmers' active : involvement in censorship, civil liberties and the Spanish situation deepened their unease over Australian public apathy about threats to parliamentary democracy. Eric Andrews has concluded that 'the common reaction [to the Spanish civil war] was indifference and the desire not to be involved. Menzies seems to have expressed a fairly widespread feeling that the outcome of the Spanish struggle was not of much interest to a British community'. ${ }^{63}$ For the Palmers, such a reaction provided more evidence that Australia was an immature society which readily accepted escapist and dependent policies in international affairs. Indeed, they found the contrast between the local indifference to Spain and the courage of the Spanish people a painful commentary on the parochialism and timidity of Australian democracy. This contrast reinforced their dismissive view that confined habitation in a mindless suburbia had consumed much of what had been desirable in the Australian national character.

When Nettie Palmer returned to Australia in October $193^{6}$ she addressed a crowded Scots Church Hall on 'Spain in Ferment'. ${ }^{64}$ Later as president of the Spanish Relief Committee and a member of the executive of the Joint Spanish Aid Council she became embroiled in an exacting round of addresses and meetings. She also collected material for a pamphlet 'Australians in Spain', which was published in May 1937 and re-issued in an enlarged edition in 1948. She wrote a foreword to 'We Went to Spain' and an article for 'Spain: The Spanish People Present Their Case', both Spanish Relief Committee publications. In her article, Nettie sketched the background to the civil war and described the situation as she remembered it in Catalonia in the months preceding the war. She had been impressed by attempts 'to manage social resources for the benefit of the many' and felt that Catalonia was 'beginning to be a people's state'. Health services were being improved, land was gradually being resumed for the use of peasants, and an air of industry was evident in and around Barcelona. She observed that until July $193^{6}$ Spain 'was pre-occupied with steady tasks of peace'. Since that date its achievements and promise were threatened by 'totalitarian war, and International invasion'. ${ }^{65}$ For Nettie Palmer, 


\section{Dream and Disillusion}

the Spanish Civil War was a brutal confrontation between a democratically elected people's government and fascist elements which sought to destroy the Republic. There was no doubt in her mind that the Australian people should support Republican Spain.

That Spanish affairs absorbed much time is evident from a diary entry of Nettie's during Spanish Week, which began in late February 1937:

V. to town by midday to speak in Spanish Shop. N. to Business

Women's Club lunch to speak, shortly, seconded well by Hilda

Bull [Esson]. Small number present but good .... To A.B.C. to give radio talk to schools: to 3 D.B. to give 5 minutes broadcast about text of Spanish week .... . To Kew Town Hall evening. Pretty full. Speakers [on Spain] Ralph Gibson \& N.P. ... ${ }^{86}$

The Spanish Shop which Nettie Palmer helped man had been set up by the Spanish Relief Committee to co-ordinate the propagandist and fund-raising aspects of Spanish Week. It soon became a centre of dispute. On 2 March 1937 Nettie Palmer recorded that 'six or eight young Catholic Action men' had entered the shop and 'dropped dud challenges', while on the following day the secretary of the Spanish Relief Committee was 'baited' by S.J. Ingewersen and some of his friends. ${ }^{67}$ Ingewersen was a member of the Campion Society, a Catholic discussion group established in Melbourne in the early i93os. It actively supported the views of the Catholic Worker, edited by B.A. Santamaria, which applauded Franco and criticised the activities of the Spanish Relief Committee. The dispute at the Spanish Shop spread to the correspondence column of the Age. K.T. Kelly, a vocal member of the Campion Society, complained he had found no 'photo of any atrocity committed by Anarcho-syndicalists' on display in the windows of the Spanish Shop but only 'Communist propaganda'. He considered it a pity that the fund had been so 'arranged ... that injured povertystricken women and children of other than Marxist families will secure practically no relief' ${ }^{\prime 8}$ A letter from Nettie Palmer and two office holders on the Spanish Relief Committee explained the purpose of the committee and the Joint Spanish Aid Council, but Kelly was not to be persuaded. ${ }^{69} \mathrm{He}$ repeated his charges and declared that it was 'a pity that a good Australian like Mrs Vance Palmer should have allowed her humanitarian sympathies to be used by the Communist Party for political ends'. ${ }^{70}$

A fortnight after this exchange Nettie Palmer participated in a 
debate at Melbourne University on the Spanish situation. The opposing team of Santamaria, Kelly and Ingewersen affirmed 'That the Spanish Government is the Ruin of Spain' and won the debate. But the student paper Farrago reported that the speeches aroused 'a good deal of turmoil' in the crowd of over Iooo, 'half of whom were outsiders'."1

Throughout 1937 Nettie Palmer addressed public meetings, schools, gatherings in private homes, and radio audiences on Spain. Most of her critics on these occasions appear to have been Catholics. At their old haunt of Emerald the Palmers discovered 'Sharp religious division ... : several old friends shook hands over fences but kept away from the meeting [on Spain] - people I had forgotten were Catholics'. ${ }^{2}$ Two months later Nettie recorded in her diary that a radio debate on Spain had 'brought in so many letters of complaint that the subject is now regarded as dynamite. The Catholic Action group is certainly active and obstructionist'. ${ }^{33}$ A year later, in February 1939, Nettie helped Norman Banks of ${ }_{3} \mathrm{KZ}$ record wireless interviews with six members of the International Brigade. Once again, there was a big outcry. Nettie noted that Banks 'had had protests all morning about the IB interview. P.M.G. on his tracks, too'. ${ }^{74}$ Opposition to the republican cause seemed strong and well organised among Catholics, while support, particularly outside of the communist movement, was often unimpressive. Nettie Palmer's diaries record a number of disappointing audiences, like the one at Sunshine in June 1937.

Sunshine! A cold, rainish day. Maurice Blackburn, as the other speaker .... Excellent place ... - but empty. All the Sunshine workers afraid to come ... though all are interested. ${ }^{75}$

There were certainly better meetings than the Sunshine one, but not enough of them to dispel the feeling that too few people were called upon to do too much work.

As the situation in Spain deteriorated, the Palmers grew increasingly frustrated by the Australian Government's failure to recognise the menace of fascism and the danger of a second world war. By the late 1930s censorship had become less severe, but the censor was still active. The German Consul-General, Dr Asmis, was able to prevail upon the Federal Government to ban Clifford Odets's anti-Nazi play Till the Day I Die and he attempted to have the Federal Government silence the Labor Daily when it campaigned against him. Lyons made abject apologies to Asmis, and later 


\section{Dream and Disillusion}

rebuked H.G. Wells for calling Hitler a 'certifiable lunatic'. ${ }^{76}$ In March I939 Wells wrote dismissively of official efforts to protect 'the tender Australian mind' from 'what they imagine to be subversive ... .77

Palmer's work for the Council of Civil Liberties gave him an inside knowledge of the mentality of those who defended censorship. In October 1937, the Federal Censor cut 3 I feet from a film which the Palmers had imported for the Spanish Relief Committee, but their protests received very little publicity. ${ }^{78}$ In 1938 , a high administrator in the $\mathrm{ABC}$ told Palmer and Fitzpatrick that he would 'go out of public life altogether' rather than explain why certain material had been censored, and a year later, Palmer was asked to make his $\mathrm{ABC}$ book talks less political. ${ }^{79}$ At this time Palmer was disturbed by the threat to civil liberties implied in the National Security Act of 1939. In a memorandum to the CGL, he argued that it was dangerous to allow a government abruptly to assume executive power in time of war. He warned that the future might bring "a period of "partial wars" in which the issues will be complex and the weapons mainly economic'. In these circumstances overdependence on powerful friends might lead to a 'reversion in the face of external difficulties, to a colonialism from which we had nearly emerged'. Palmer felt that rather than helping the war effort, the powers of the War Precautions Act had concealed 'slackness, sometimes inefficiency, in a few cases (it is suspected) corruption'. Moreover, they 'were used increasingly for political ends'. As a result:

The post-war world suffered from a loss of political capacity caused by war-time regulations, and the confused nature of the fight against them. The democracy, as a whole, was driven into sullen defensiveness, a distrust of any kind of foreign policy. Interest in the rest of the world was suspect: the easy way was to retreat into isolationism. Both in the industrial and the political arena this conservative defensiveness had ill effects, which continued for years. ${ }^{80}$

Palmer believed that Australian democracy was gradually atrophying, a slow process that had its beginnings in World War. I. $\mathrm{He}$ argued that suburbia, the growth of censorship and isolationism were symptoms of this decline, indicating that the nation had abused its capacity for democratic. government. 'Democratic governments', he wrote, 'should not merely assume the people's responsibility but cultivate their sense of it', a sentiment which 


\section{The Inter-war Years}

echoed his old belief that Australian democracy could set an example to other nations. By the outbreak of World War II this hope had all but died. Palmer now only hoped that Australians could combat fascism without surrendering more of their liberties than the demands of war required. In his more pessimistic moods he was not confident that even these modest hopes would be realised.

In October 1936, on her return from Europe, it seemed to Nettie Palmer that Australians needed to be shaken from complacent slumber to face the realities of a violent and uncertain world. However, she doubted whether Australian writers were sufficiently aware of external events to perform this task. But by 1939 she had detected a change with the appearance of new works such as Leonard Mann's manuscript on 'The Impending Crisis' and Frank Dalby Davison's 'While Freedom Lives', an anti-fascist pamphlet published in November 1938, which he privately described as a 'Christmas surprise for our Fascists'.81 These works suggested that the Australians' image of themselves no longer suited the realities of the late 1930s. Hartley Grattan shared this view. After six months in Australia in the first half of 1937 he saw a need 'to bring Australian conceptions of Australia's future in line with probabilities. The men of the nineties', he told Nettie Palmer, 'certainly talked wonderful rubbish on this subject [Australia's future] and a good deal of it passes for wisdom to-day'. ${ }^{82}$ Grattan commented later that 'Australia drifts. She awaits a cue. And there is no-one to give it' ${ }^{83}$ In 1942 , Brian Penton savagely criticised a people content to 'drift' in 'lotus-land fantasy'; a people who had apparently lost 'the dynamic will to survive'. ${ }^{84}$ These critics may not have agreed about the nature of the national malaise, but all suggested that the nation was in a poor state. Penton was characteristically blunt. $\mathrm{He}$ accused Australians of self-deception for they cherished the 'legend of the independent, free-thinking Australian mind', but acted with 'spineless timidity in the face of authority'. ${ }^{85} \mathrm{He}$ pictured them as people who 'huddle[d] together in self-protective mobs against the strangeness and dangers of a new country'. Penton maintained that Australia was 'Not a brave new world at all, but a respectable old one, hiding its head from civilisation's restless, innovating thought' ${ }^{86}$

While Penton's frustration with Australia arose immediately from his experiences in the I920s and 1930s, his anger also drew upon a critical tradition which went back before World War I and is apparent in the writings of Palmer, Esson, Sinclaire and Wilmot. The allegation very commonly made was that a truly 


\section{Dream and Disillusion}

Australian 'people' had not emerged from the settlement of the continent. Critics differed in their definition of 'a people' but tended to agree that no society which was conscious of shared goals would tolerate piecemeal and directionless policies for as long as Australia had done. In 1937, Nettie Palmer expressed many of those doubts when she wondered:

if there isn't some essential lack in us, something missing that keeps our life from having meaning and depth - interest in our past, reverence for those who have shown outstanding qualities of mind or spirit. When we look back it is on great empty spaces; the significant dead have no memorials; the few statues in our parks are mainly of forgotten grandees and kings. It must be because we have no sense of ourselves as a people, with a yesterday and $a$ to-morrow. ${ }^{87}$

In 1942, when Australia was again at war and a Japanese invasion threatened, Palmer wrote another article on the failure of Australians to become a people. ${ }^{88} \mathrm{He}$ maintained that there was little evidence in Australia of a people 'with a common purpose or a rich sense of life'. There were 'no monuments to speak of, no dreams in stone, no Guernicas, no sacred places .... How many penetrated the soil with their love and imagination?'. Nor was there a 'peasant population to cling passionately to their few acres, throw down tenacious roots, and weave a natural poetry into their lives by invoking the little gods of creek and mountain'. This lack of passion, tenacity and folk-tradition was matched by the barrenness of Australian towns; 'the suburban retreats of rich drapers!', as Palmer described them, echoing Will Dyson and Louis Esson before him. To Palmer, the towns were spiritually dead, 'full of men and women intent on nothing but buying and selling'. However, he discerned a second Australia behind this shallow façade which had many features in common with the society Sinclaire had described twenty-five years earlier in 'The Two Australias'. This was 'the Australia of the spirit', an elusive emanation 'Born of the lean loins of the country itself, of the dreams of men who came here to form a new society, of hard conflicts in many fields, it has developed a toughness all of its own'. Palmer's 'Australia of the spirit' evoked an ideal of native strength and determination struggling for self-expression. He hoped that Australia would 'come out of this struggle battered, stripped to the bone, but spiritually sounder than we went in, surer of our essential character, adults in a wider world than the one we lived in hitherto'. It was the hope of a man 


\section{The Inter-war Years}

who had long wanted Australia to be rid of the doubts and insecurities which he attributed to colonialism and 'mediocrity'. Yet there was a repetitive air about Palmer's charges and something darker perhaps than he cared to admit in his vision of the 'battered' nation.

Palmer's style of argument in 'Battle' was a familiar one for anyone who had followed his career as a writer. It is clear that he felt the need to criticise aspects of his society. Typically, they were the effete and derivative elements which had either been imported from another culture or were commercial perversions of 'natural man'. Palmer maintained that these alien influences had created false selves which the Australian people would have to reject before they could realise their potentialities. He was vague about the attributes of this better society, but this too was characteristic of his position. The benefits that would flow from a heightened national consciousness were rarely specified. The logistics of Palmer's Meanjin argument revealed a man who was troubled by his being a writer in a derivative, colonial culture. Palmer was aware that it was merely crude chauvinism to find no fault with his society, yet it smacked of betrayal to repudiate the land of his birth. The many variants upon the theme of the two Australias enabled such a man to criticise the level of cultural awareness in his society, not from the apparently superior stance of the culturally well endowed, but in the name of a profounder national consciousness. Yet this division could lead towards a caricature of the surrounding society and a sentimental vagueness about its supposedly more fundamental self. This mentality enabled Palmer to alternate between waspishly dismissive caricatures of rich drapers and indulgent meditations upon the Australia of the spirit. 


\section{Vance Palmer's Writings}

Palmer's writings have been highly praised by several prominent critics, notably Jack Lindsay, A.D. Hope and H.P. Heseltine. ${ }^{1}$ This chapter offers a different and on the whole less favourable account of Palmer's imaginative writing. It should be stressed, however, that in a more balanced review Palmer's short stories would receive more attention than they have done here, particularly the two collections Let the Birds Fly and The Rainbow-Bird. ${ }^{2}$

In his short story 'The Bridge', Palmer describes four characters each of a general type which recur in his stories of station life. ${ }^{3}$ The four were Maynard, the owner of Dulacca Station, Nina Hemming, his young bride; Hurley, the rotund man of commerce, and Rhoda Bassett, a bold femme fatale. As a girl, Nina was raised in a household of women whose main pastime was music. The story concerns Nina's problem in adjusting to the practicalities of station life and the anxieties Maynard felt during this process.

Maynard disapproved of the Hemmings' upbringing. He felt that Nina and her sister Margaret had 'lived more fully in a transcendental world of music than in the more tangible world about them'. He noted Margaret's disconcerting intensity whenever she played the piano, and was apprehensive lest Nina, although seemingly less endangered, would also develop the oddness of this 'queer girl'. At Dulacca, Nina was dependent on Maynard's protection. At first she experienced periods of loneliness, self-doubt and withdrawal, but eventually she learned how to be 'at one with her surroundings.' In describing this transition Palmer transfers Nina from what he regarded as an insular and effete cultural background into a more practical atmosphere. Nina is to become less feminine and more capable and self-reliant, so that she can achieve an easy camaraderie in her marriage with Maynard, and later her assigned place in his masculine world.

This resolution to the story allowed Palmer to steer Nina and Maynard towards a happy ending, without undertaking a closer analysis of their more complex and contradictory emotions. 


\section{Vance Palmer's Writings}

In the process, many of his descriptions verge on caricature. For example, Maynard's reflections on music and his robust pronouncements on 'life' often seem merely narrow, not noble and life-affirming. Although it is clear that Maynard is meant to be altogether more bold, practical and rough than the sheltered Nina, the crudeness, violence and coarseness attributed to him are never convincingly displayed. His character is drawn rather inconsistently. $\mathrm{He}$ is described as a 'roystering, hard-living' cattleman with 'free and easy' habits who can nevertheless become coyly sentimental in his relations with Nina. He felt that 'no man could live for long in a feminine atmosphere without desiring a relief from its shadowy refinements' yet despite the bravado of 'careless, exuberant living' of men 'singing and drinking' and all the associations of a 'robust, masculine world', Nina remains 'magical'. We learn that 'the close intimacy of their long evenings alone did nothing to dispel the delicate glamour that hung around her' and that Maynard 'would surrender everything to the woman he loved, even his life that was part of him'.

'The Bridge' is a conventional story, conventionally told. Its toughness is contrived. One of its least satisfactory aspects, although crucial to the story, is the description of Nina's change from an inhabitant of a world of music to a station owner's wife 'at one with her surroundings'. The change occurs while Maynard is away from the station for three days. On his return he detects a new 'poise and sureness' about his wife: 'Even her voice seemed to have changed. Though subdued and modulated, it had a quality of robustness and assurance that he had never known in it before ....' The cause of this change is Nina's pregnancy, a fact so delicately insinuated that it would be possible to read the story without ever being aware of the precise nature of this 'miracle that had brought her into touch with the common soil of life'. She is now able to tell Maynard quite calmly of Rhoda Bassett's visit during his absence, despite the fact that Rhoda's 'bold enquiring eyes' had revealed a mysterious past association with Maynard. Nina also displayed a new found assurance and ease in conversing with the capable, pragmatic overseer's wife. The 'miracle' that had been wrought in Nina then releases Maynard's spirit. 'from its long tension' and the story ends with his rather feeble reflection that 'life ... has its own laws of harmony'.

Attention has been given to 'The Bridge', not because it is a very good short story, but because it clearly demonstrates limitations 


\section{Dream and Disillusion}

which also mar many of Palmer's later writings about station life. It also describes a setting which he was continually to return to in later work: the outback station set in mulga country, with its white pisé homestead, wide verandahs, pepperina trees, lagoon, native camp and nearby shanty. It appeared in the play, The Black Horse, in a number of short stories, in pot-boiling novels like The Shanty Keeper's Daughter and The Boss of Killara and in more serious novels like Cronulla, The Man Hamilton and Men are Human.

Palmer's accounts of station life owed much to his experiences at Abbieglassie Station. The Man Hamilton provides one example. In a letter to Nettie in March I910, Palmer tells of a haunting evening he had spent with an unusual man, a station owner named Hamilton who lived nearby. ${ }^{4}$ Palmer found Hamilton 'reserved, grey-eyed, and fond of a few uncommon books', a man with a 'peculiarly delicate sense of honor', but describes his wife as merely an 'unprepossessing gin' although he conceded that she may have had 'some fleeting grace or other' when Hamilton had married her eleven years earlier. 'I don't care to think of his life too much', Palmer wrote: 'God knows I have always tried to shut myself to the differences of colour and caste that help to keep men apart, but how can life be bearable to two people in such isolation, with such continual proximity, unless they love one another with the very breath of their souls and be kin in thought and dream?' Too much could be made of this response, but it suggests a young man who did not want his rosily romantic notions of conjugal happiness to be upset by the murkier depths of Hamilton's marriage. Almost twenty years elapsed between this letter, written when Palmer was in his mid-twenties, and the publication of The Man Hamilton in 1928. One might have expected that the intervening period would have allowed Palmer to probe the nature of Hamilton's situation in some depth. Hamilton's apparent loneliness, his sense of honour, his meditative outlook, his interracial marriage might have provided the materials for a powerful character study of a man in an isolated world, but Hamilton's background, his character, his relations with his wife and his introspective nature are obliquely and hesitantly portrayed. Just as damaging is the absence of a figure like the young Palmer, someone whose innocence was shaken by Hamilton's world. A pervasive narrator who reflected upon events and measured their significance, clumsy though he may have been, could well have given the novel a necessary extra dimension. As a medical student, Hamilton had suffered a nervous breakdown and had gone to 


\section{Vance Palmer's Writings}

Euroa, the family property, to recover. His stay is extended and he marries Lottie, the part-Aboriginal daughter of an old hawker, who bears him a son, Steven. The reasons for Hamilton's marriage to Lottie are never very clearly stated. She is associated in Hamilton's mind with the mystique of Euroa and with boyhood memories of 'deeper and darker tides of feeling' aroused by a corroboree. Some impulsive, primitive streak in Hamilton's nature appears to have drawn him towards the Aborigines, so that with Lottie it became 'inevitable that he should take what seemed to be so freely offered'. ${ }^{5}$ Lottie, however, falls pregnant, although like Nina in 'The Bridge', this fact is never explicitly stated. Hamilton equivocates, but finally marries her despite the knowledge that she 'was not the woman he would have chosen for a life-companion'. The marriage is a failure as Lottie succumbs to a 'slow, creeping torpor', and Hamilton is left only with 'the world of men, and his own standards of what was a decent life. Other men in a like position, he knew, had gone down. He was determined that he would not'. ${ }^{6}$

The novel begins some fifteen years after Hamilton's marriage, when he is forty and Nina Byrne, a governess, arrives at Conondale, a neighbouring station. At this point it is interesting to speculate why Palmer chose to develop the novel in terms of a relationship between Hamilton and Nina. On reading the book, Katharine Prichard supposed that Nina had been introduced for the 'box office', perhaps a reasonable suspicion, but it may have also been due to Palmer's difficulties in developing alternative themes. ${ }^{7}$ It is clear that he did not want to examine the relationship between Hamilton and Lottie and neither were the routine tasks of station life a sufficient vehicle for his purpose. Two months after Palmer had begun The Man Hamilton, Nettie noted in her diary that the writing was progressing 'steadily' but that Vance was 'dreading a difficult stretch soon'. ${ }^{8}$ Did this arise from the barrenness which descended on Palmer's setting when he avoided examining Hamilton in his true social and intellectual context? Perhaps. Certainly, the love affair between Hamilton and Nina was conventional 'copy' for a novelist uncertain of what to do with his hero.

Hamilton's affair with Nina Byrne forces him to choose between his desire to live with Nina and resume his medical studies in the city and his responsibilities to his son, his wife, and the family property. He finally chooses the latter, although in doing so he must repress 'impulses that arose from the very heart of life', a cloudy region that Palmer nevertheless often alluded to with confidence. ${ }^{9}$ 


\section{Dream and Disillusion}

The shift from Maynard's bland fate to Hamilton's more tragic and divided one indicates that Palmer had become aware that the search for 'laws of harmony' to dissolve discord and division could be shallow and evasive. But although it shows promising developments, The Man Hamilton did not allow Palmer to refine his new perceptions. The conventional station setting, the diffident handling of relationships between men and women, the convenient death of Lottie's father, all obscure the moral implications of the story. Palmer did not want to probe Hamilton's darker impulses, but neither did he examine the social relationships which marriage, fatherhood and the management of a large station entailed or the reactions to his extra-marital activities. Hamilton is a curiously insular and obliquely drawn character.

Palmer's last station novel, Men are Human, displays a more confident handling of character and theme than The Man Hamilton. Even so it has disappointing features. This is particularly so in the treatment of Boyd McCurdie, the station owner's son. An erstwhile law student, McCurdie has returned home from the war, seeking 'time to think, to discover the self that had been split in two fragments on the anvil of war, to make his own decisions about what he was going to do with his life'. ${ }^{10}$ Thus it might appear that Palmer intended to give more scope to the theme of inner division in this novel than he had in his account of Hamilton. But again the inquiry comes to very little. Boyd gradually assumes less importance in the novel and is finally killed off in a riding accident with the problems of his personal development left unresolved.

Palmer has often been praised for his treatment of the common man, so it is informative to look at the background of some of his main characters: just how common were Maynard and Nina Hemming, Hamilton and Nina Byrne or Boyd McCurdie? Maynard inherited Dulacca from his father. On his rare visits to town he mixed with old school friends, 'mostly lawyers, doctors, or leisured dabblers in land and mines'. His wife-to-be is the refined daughter of an engineer, a man of evident standing in his community: Like Maynard, Hamilton also comes from a wealthy propertied family. He had spent some years as a medical student and had a well stocked library, although little is made of his intellectual interests. Nina Byrne was the daughter of a 'voluble, energetic man, [who] dabbled in mines and small ventures'.11 After he died Nina taught French and music at a girls' school and then moved to her brother's orchard for a time before becoming governess at Gonondale. Boyd 


\section{Vance Palmer's Writings}

McCurdie was the son of an aggressively conservative cattleman, a local member and 'big noise' in his district. Boyd had just been called to the Bar in Sydney when war broke out. He enlisted, survived and stayed in Europe for a period after the war.

It seems remarkable how much duller Palmer's characters are than their biographical details would suggest, a fault which must lie with their creator. No effort, for instance, has been made to describe McCurdie's student days, to account for his enlistment, or to indicate his impressions of Europe. Palmer can hardly have been unfamiliar with this background for he had lived through the war and had enlisted. He knew students well and had visited France, England and Ireland after the war. Yet these omissions would be trivial if Palmer had compensated for them in other ways, but this he fails to do. The pale fiction he created in the I920s is a damaging failure for a man who dedicated his energies to the creation of a national literature.

Palmer's reductive bias also appears in his attitudes to women. In 'Novels for Men', a Bulletin article published in 1923, Palmer defined the differences between male and female audiences. ${ }^{12}$ He deplored the fact that most modern fiction was written for women as this produced a 'microscopic, intense and rather suffocating' atmosphere, an atmosphere he later described as 'warm and ennervating, like a small room heated with an asbestos stove'. Not an elegant metaphor, but one which indicates Palmer's fear of female constraint. Palmer emphasised manliness because he felt that manly qualities were threatened by the feeble tastes of a largely female reading public. Men, he felt, wanted 'vivid character, robust humour, a touch of philosophy, and tragedy without a superfluity of tears'. He was thankful that the 'small public' for Australian writers was 'largely composed of men' and hoped that the local writer would be 'sheltered from that feminine public that would destroy them'.

Palmer's admiration of manliness was an integral part of his view of the good society and had been for some time. In a letter to Nettie, in 1909, Palmer suggested that the male had a monopoly of the 'terrifying and life-giving' which he hoped would be socialised. In contrast he was 'sometimes struck by the evasions and lack of intellectual sincerity in the attitude of a good many young women towards life ... '. Later in the letter he condemned the 'middleclassishness' of English women, their 'belief that life was made for polite conversation, that they must merely chatter when they meet 


\section{Dream and Disillusion}

men, and that refinement is the only reality ...' ${ }^{\prime 3}$ Many of Palmer's criticisms would have been met if more ease and informality had been introduced into relations between the sexes. Accordingly, he was not against the actions of the suffragettes, as indicated in a letter to Nettie in I 9 I o soon after a massive suffragette demonstration in London. Palmer felt the suffragettes deserved praise for showing men 'that sex isn't the only thing that interests them'. But at the same time, he felt that the suffragette movement was not as new and unprecedented as many people supposed, but was merely 'leading to a state of things present in every community that is really healthy and virile: where sex is a private matter between each particular man and his mate and there is a whole world of things in which men and women meet on common ground'. Palmer believed that it was 'only in very artificial and decadent countries' that sex became 'an obsession to the whole community'. His thoughts then turned to a small Australian rodeo-type performance called 'Wild Australia' which he had visited at the Crystal Palace. The juxtaposition of English girls in the audience and Australian girls in the ring, enabled Palmer to see 'clearly what I had been seeing dimly and at angles for some years'. He described two English girls who were 'well-dressed, refined enough, correct by any suburban standards, yet with just enough apparent in every movement ... to show that they were weighing its effect on any casual man'. By contrast there were ' $a$ dozen girls and men from the bush. The girls all brown with bare tanned arms and short skirts and tumbled hair'. Palmer was struck by their relaxed and informal manner as they 'stood in groups talking in their slow, slangy way with just that suggestion of impersonal interest and joy you find when men talk together or women talk together, but not when they meet in drawing rooms. ${ }^{14}$

Palmer frequently implies in his writing that he wanted women to develop what he considered a mainly male capacity for 'impersonal interest' and independence. In much of his correspondence he addresses Nettie as 'mate'. The title of his first book of short stories, The World of Men, carries overtones of the 'virile' and 'healthy' community Palmer sought. In 'The Bridge' Nina Hemming was clearly a 'feminine' woman, while Rhoda Bassett with her 'direct eyes that looked at everything as if they were unhampered by veils and illusions' was described as a woman with a 'rather masculine face'. The sexual themes which occurred in Palmer's letters, his relationship with Nettie, the differences between English and Australian women, the implications of the suffragette movement, 


\section{Vance Palmer's Writings}

all provided rich material for the artist. But what appeared in Palmer's letters as promising and suggestive themes for the intending writer, often appeared later in cruder and more dogmatic forms. Nettie, Hilda Esson and their career-oriented friends, for example, provided fine models of the new woman capable of finding 'common ground' with men, yet the scope of this theme was debased in much of Palmer's writing by its melodramatic location in the outback shanty where women like Rhoda Bassett stared down tough cattlemen like Maynard, or where a woman like Nina Byrne becomes a source of romantic upheaval and little more in The Man Hamilton. Palmer's dismissive unease about bourgeois femininity might be understandable, but unchecked in a writer it could too easily slide into misrepresentation and over-simplification.

The fear of intimacy which weakened Palmer's writing up to the end of the r 920 also appears to have marred his relationship with Nettie. In a letter written from Melbourne in 1930 she accused Vance, then on board ship to England, of diffidence and indifference, not unusual complaints judging by the tone of the letter. Nettie had found an old letter Vance had written to his family in 1910 and was struck by how inadequate his recent letters were by comparison. She wrote:

It must seem to you that I'm a little mad, to doubt your love for me: \& yet - can't you imagine that I need some utterance of it? I'll try to explain \& then put it all away. Mabel happened to send me an old letter you had written home from London in I910. It was charming \& interesting \& friendly \& affectionate towards them all: I felt proud of you - all that time ago - writing so adequately. And you speak of being tongue-tied! It was far more explicit about your feelings than your letters to me today. Oh, I can't help it if my demands sound vulgar \& foolish, but how can I bear it when you always say you are lonely 'without your family around you'? God knows I'm glad you love the children \& I could never be jealous of them: but do you never remember our intimate life together? What different letters I would be writing to you if I had even a hint that you could endure them! Its all very well for you to be patriarchal \& sensible: I don't look on you as the head-of-the-house but as a lover. I'm middle-aged \& plain, I know, but then I never had any looks to lose \& I oughtn't to be just a woman who runs a house (I'm not very brilliant if that is my calling!) You'll say I'm playing with words \& that I must know you better than to dwell on accidental omission \& indeed I must, or I couldn't write to you so frankly, appealing from Caesar to Caesar in this way. And yet - if I could show you your letters, so . . . No, 


\section{Dream and Disillusion}

I won't go on, though something drives me to write down the very demands that most exasperate you. Burn [?] [ ? ] of these letters of mine. They are tortured \& only half true, perhaps: I'm just feeling towards some truth of expression, in a bewildered way. You'll say, of course, that nothing written on a crowded ship should be taken against you. But your letters have been brilliant, (masterpieces, Aileen says!) detailed, ironic, observant: only not the letters of any one who could imaginably be a lover of the person to whom they are written. As for me, you'll say I can't be your lover if I choose to nag \& rasp on in this way. Well, I haven't been at ease with you. I find it hard to write down the words that mean so much between us - as if I had always been cloying you with honey.

Have I come back on the same track again, after saying I would leave it? Well, here's good bye to it. No more reproaches! In spite of your silence \& evasions (you'll say they are not intended) I'll dare to tell you I love you \& want you. And you'll somehow forgive me for my petulant demands. Always it has been like this - always you have had to forgive me. ${ }^{15}$

Nettie alludes to the techniques Vance used in order to avoid talking intimately of their marriage. We learn that he could accuse her of 'playing with. words,' of stressing 'accidental omissions' and of ignoring the circumstances in which his letters were written. He might profess to be 'tongue-tied' or he might emphasise his 'patriarchal and sensible' self or suggest that she was suffocating him with syrupy emotion, or indeed that her accusations made her unworthy of his love. Nettie charged that he would resort to 'silence and evasions' rather than trying to satisfy her emotional needs. The tensions Nettie's letter sought to expose and resolve illuminate much of Palmer's writing, particularly his fascination with the world of men and practicalities, his concern with manliness, and strength, his wariness of emotion, 'the feminine atmosphere', suburbia and the suffocating crowd.

Palmer felt awkward in intimate situations and preferred to keep some distance between himself and other people, including Nettie. However, it may be supposed that his defences against intimacy also became part of his more general outlook as a writer and social critic. The impulse to escape from the bonds of intimacy to the wider freedoms of a society which valued manly independence is a recurring theme in his writing. Accordingly, manliness, work, space and the bush signified the casually democratic air Palmer favoured, while women, intimacy, the city, the suburb and the drawing-room threatened this world. There were exceptions to this rule, but chiefly 


\section{Vance Palmer's Writings}

where the woman surrendered herself to the man. Nina Byrne, for instance, told Hamilton that 'her life was his' at which he showed surprise for he had always thought that 'life was a long bargaining' with women. ${ }^{16}$ Nina seemed to offer Hamilton an escape from the limitations of his marriage, but primarily because she was entirely subservient. Palmer, like Hamilton, felt entitled to a certain expansiveness of spirit. He felt that the Australian was not called upon to live within strict physical and emotional confinements, for it was his mission to recover a largess which modern man, supposedly, had lost. However, the feeling of liberation from 'English' restraint and over-civilisation could become a difficult illusion to replace, particularly where it seemed to excuse those who shared it from self-scrutiny. Accordingly, while the code of manliness, for example, could have its appealingly tolerant aspects, it also had its darker, narrower and more insensitive sides which bred conflict and estrangement.

If Palmer's station novels were inadequate in the early 1920s, they became more so as the decade wore on and old assumptions grew less tenable. As Louis Esson found, it became harder to ignore the importance of ideas in literature than he had once supposed. 'I was always afraid of literature being side-tracked by ideas', he wrote to Palmer in December 1926 'but I am inclined to think now that things are all mixed up, and cannot be separated, and that literature cannot help being influenced by politics and morals, and sociology and science and all modes of life and thought'.17 It could be inferred from this letter that Esson was no longer confident that the attempt to portray 'life itself' in the elemental bush setting was an adequate basis for a national literature. It followed that the Australian writer should take a broader and more inclusive view of his society. This view gained support in the 1930 shen it became evident to many Australians that their community was insensitive to the dangers which faced democracy at home and abroad. In the 1930s, the Palmers feared that the future of democratic government was endangered by fascism and that the Australian people had to be warned of this menace. At the same time they were to be reminded of the democratic traditions which had shaped their nation. These changes did not produce dramatic new departures in Vance Palmer's writing, but they encouraged him to adopt a more sceptical attitude to his own assumptions in a decade when younger Australian writers and thinkers like Elcanor Dark, Christina Stead, Kylie Tennant, Brian Penton and Xavier 


\section{Dream and Disillusion}

Herbert were questioning many received opinions about the nation's past. War and its aftermath had inspired much of this new writing, while the onset of the depression gave urgency to further national self-examination, an observation which is supported by the appearance of numerous little magazines from around the mid-1930s. ${ }^{18}$ However, the Palmers were not always at ease in this more disputative environment. Early in $193^{2}$ Nettie Palmer objected to the modern emphasis on intelligence rather than feeling, on taking the world to pieces and examining it rather than in celebrating the virtues that would hold it together'. ${ }^{10}$ She saw conflict between the disruptive spirit of modernity and the pursuit of feeling, wholeness and coherence, between forces which disintegrated society and those which strengthened it. Contrasts of this kind are central to The Passage, but The Swayne Family and Legend For Sanderson show Palmer to be less certain about what Nettie had called the virtues that would hold the world together.

The Passage could be read as an elaboration upon Edward Garpenter's belief

that no individual or class can travel far from the native life of the race without becoming shrivelled, corrupt, diseased .... . By the native life I mean the life of those... who live and support themselves in direct contact with Nature. ${ }^{20}$

Similar beliefs had drawn the Palmers to the Queensland coast in the 1920 . They were strengthened during this period by Vance Palmer's fear that simple virtues were becoming increasingly endangered in Australia by a shallow cosmopolitanism. Palmer had held similar views since before World War I, but had had difficulty in finding a form and setting that would express them adequately in the novel. In The Passage, more than any of his previous novels, Palmer dwelt upon the contrast between the therapeutic rhythms of the 'native life' lived close to 'Nature' and the more disordered and corrupting rhythms of bourgeois individualism.

Palmer's first thoughts of The Passage began to stir early in 1928 , when he had grown familiar with the area around Caloundra. In January 1928 Nettie wrote that Vance was 'haunted by a novel he wants to write .... Lay awake at night \& got the flow of it'. She added that he was determined 'to spend some time in the winter going up the Passage fishing with Tripcony'. ${ }^{21}$ Nettie had earlier pictured Tripcony as a good man and an experienced one, 


\section{Vance Palmer's Writings}

but not through reading or travel. There's no reason to believe he ever left this stretch of half landlocked water ... and he certainly has no impulse to read about foreign places; but [one or two local] books ... enrich the familiar world for him, and perhaps help to make him the decent, essentially civilized man he is. ${ }^{22}$

Tripcony was a man who had lived well within a confined locality. His few local books did not make him impatient with his world, but helped him to understand it better. This sketch of the 'essentially civilized man' corresponds in important respects with the attributes of the craftsman who, in Palmer's view, brought a measure of artistic awareness to bear upon the practicalities of everyday life.

Lew Gallaway, the main character of The Passage, was a man cast in the Tripcony mould. He was a fisherman who owned his own boat and went on to plan a co-operative. In his personal affairs, Lew had disappointments. His mother found him rather slow-witted and unambitious and preferred the flashier company of Lew's younger brother, Hugh. She later learnt that her judgment had been wrong, but in the meantime Lew had lost his son, gone through a broken marriage and had remarried more happily. Apart from these more dramatic interludes Lew's days were occupied by the unobtrusive events of his daily life: his work in the boat, at sea, at home and in the local community, yarning at the store and lazing on the beach; activities conducted against the impressive background of the sea and the surrounding coastal landscape. Hugh Callaway developed differently. He was anxious to escape the Passage, for it soon cramped his money-making style and his love of fast living. As his fortunes rose, Hugh fraternised more and more with salesmen, speculators, wealthy tourists and admiring women. In contrast to Lew, the rhythm of Hugh's life was hectic. Speed and sports cars fascinated him. So did mechanical progress. However, Hugh was finally cheated by one of his business partners, abandoned by his admirers and once again dependent on Lew.

In his love of fast living, the bright lights, city adventures and the stimulus of newer and bigger commercial transactions, Hugh Callaway emerged as the betrayer of Lew Callaway's steadier and more worthy values. For Palmer, Hugh displayed the faults of the provincially minded: 'a society is provincial', Palmer wrote in 1926, 'when it looks to some other centre to set its standards of living. ${ }^{23}$ Hugh Callaway had always yearned for a more glamorous world than the Passage. He 'wanted to be in some centre where 


\section{Dream and Disillusion}

he could match his capacities against those of other men ... feel in the vibration and hum of ceaselessly-moving wheels that he was part of a city that was linked to other cities all around the world'. ${ }^{24}$ Characteristically Hugh was excited by the proposal to establish an elaborate tourist resort at Lavinia, near the Passage, whereas Lew looked down upon the resort as 'an artificial growth, a place that depended on a flow of life from outside'. ${ }^{25}$ Lavinia's world of fast cars, jazz bands, drinking and wealthy tourists bred a dangerous confusion in Hugh's mind. He went so far as to burn his garage for the insurance money, but was able to minimise the enormity of his act, even justify it. He spoke to Lew of Anna's absurd respect for property as a remnant of days 'when men moulded and shaped things painfully with their hands'. Not only did he sneer at craftsmanship, but his reputation as a destroyer of sane values soared when he uttered some improbable statements about the war. He spoke of

How swiftly mechanical development had leapt ahead during the war when millions of men were occupied with destroying things by explosives or fire! A man who had any respect for mere durability was a fool. The more durable a machine was, the more it choked the stream of progress. ${ }^{26}$

While Lew was aware that his brother had run into serious financial and personal difficulties, he retained a faith in him which on the evidence seems misplaced and suggests that however wholesome the Passage had been, it had done nothing to sharpen Lew's judgment of character. Lew persuaded Hugh to take over the local store, believing that a return to the Passage would cure him of his erratic ways, but Hugh had other thoughts:

A man couldn't spend all his days in a place like this, where there was nothing to whip up his pulses when they were flagged. Sooner or later he would have to make a break and get back to the air that stimulated him. ${ }^{27}$

Hugh is by no means the moustache twirling villain of music hall tradition, but his moral frailties do fit rather too conveniently into Palmer's preconceived patterns of behaviour. He is another lost figure in the cosmopolitan world of the city whose fall is all too predictable.

While Hugh Callaway came to grief, Lew just as predictably survived disappointment to become a source of stability and 


\section{Vance Palmer's Writings}

reassurance to his mother. At the end of the novel Anna Callaway brooded 'on the image of Lew, her mind evoked from the night, the dark eyes so like her own, the potency of the slow-moving body, the way he drew power from the earth beneath him'. ${ }^{28}$ Lew's story represented the vindication of the elemental qualities: outdoor work, simple living and intimate contact with the natural world. We are led to believe that the style of Lew's life accounted for his honesty, strength of character and steadiness of purpose but, as with Hugh, the suspicion remains that his character and fate were contrived to suit Palmer's preference for nature over nurture, soil over city, unobtrusive steadiness over display and silence over talkativeness. Palmer's need to defend his own conception of authenticity, integrity and creative growth led him to romanticise the strengths of Lew Callaway and dismiss: the motivation and interests hinted at in his younger brother Hugh.

It should be pointed out that this opinion of The Passage is not shared by Heseltine. He praised The Passage, 'the rich harvest of the 'Palmers' joint lives', for its 'sure control', its 'special triumphs of tone and mood', its 'triumphant pattern which bespeaks coalescence of conception and execution' and its 'first genuine triumph of characterisation'. We read of 'Palmers new found eloquence', the 'new vivacity infused into his prose', the 'concreteness and vigour of his language', the 'finely manipulated focus of vision', the 'unadorned heart of Palmer's vision', his use of 'the exactly vitalising word', his 'increasingly vivid interest in social behaviour', his 'mature sense of life as continuous process', his 'loving fidelity to place', his 'wonder and delight in the espousal of the ordinary' and 'his sympathetic prose and the interwoven revelations of counterpointed scene and observed detail'. ${ }^{29}$ To support his case, Heseltine quoted the 'very first, well known paragraphs' of the novel. Heseltine's exultant prose is misleading, for it overlooks the limitations of Palmer's characterisation and the failings which marred his writing. After the opening paragraphs which described Lew Callaway's physical surroundings Palmer attempted his first account of Lew's state of mind. The style falters immediately. It is clumsy and self-conscious:

A fascinating world for Lew, one that liberated his mind! He had come out over the bar in a bad mood, chewing the rag, as old Uncle Tony said, because of his feeling that too much weight was being put upon his shoulders. A man shouldn't be forced to carry the heavy end of the log all his days! He shouldn't have 


\section{Dream and Disillusion}

to keep his back bent, day in and day out, while the rest of the family got anything good that was going! Yet his mother didn't consider him when she was making her plans, never had considered him. She was talking of sending Hughie away to school now - as if they hadn't had a hard enough job to keep Fred and Marnie with clothes on their back and shoes on their feet! Pulling continually against a headwind; that was what it was like; and he'd had a bellyful of it! If there was one thing he'd looked forward to it was the day when young Hughie would leave school and lend him a hand with the nets, but that morning he had found his mother nursing a fixed resolve that Hughie would never become a fisherman. ${ }^{30}$

Palmer's wooden vernacular is perhaps explained by a diary note of Nettie's in September 1929: 'V; steadily revising "The Passage". It is to be full and rich with idiom: voilà.' 31 The note suggests a rather cold-blooded determination that 'idiom' should be sown throughout the novel in order to give it the required down-to-earth flavour. There were also stilted passages of a different kind describing Clem McNair's thoughts. She was once saddened to find a cowrie which had been killed by a parasite: 'The thought made Clem's brow knit slightly, and her expression change to one of brooding bewilderment. How often had she been tormented by the mystery of this prodigal creation of beauty that went hand in hand with a callous disregard of the thing achieved' ${ }^{32}$ Similar wordiness mars some of Palmer's descriptive passages. The first sentence of chapter two is not uniquely ungainly: 'By the ricketty jetty, where a breakwater of loose stones had been built up to fortify the crumbling banks, a boy of nearly fifteen was bending over a half-finished canoe, stretching the canvas carefully over the light ribs and frowning slightly at a mark of fraying on the surface'. ${ }^{33}$ These passages hardly suggest an unfaltering stylist with an eye for the 'exactly vitalising word' or a 'genuine triumph of characterisation'.

In The Swayne Family the scene shifted to the city, although given Palmer's bias it is appropriate to think of the novel as an 'anti-city' work, for Palmer objected to Melbourne in particular and Australian cities in general. His attitude to Melbourne is clear from a letter to Frank Wilmot. In 1927 Palmer asked after Melbourne 'or rather that part of it that matters'. He mentioned Sinclaire, the 'pleasant little talks and gatherings' of his Melbourne days and his occasional desire to return there immediately. But this rashness always passed when he thought of 'waking every morning to the Argus, and Sunday morning in Kew'. He supposed that it should have been possible 


\section{Vance Palmer's Writings}

'to work in peace [in Melbourne] without letting small frictions wear the edge off the mind. Or else one ought to try and produce a different atmosphere'. But, he asked Wilmot: 'Haven't we all tried though?'34 When asked in an interview three years later why he did not write about Australian city life Palmer replied that 'the life of our cities has been definitely inferior to that of the country'. It was 'provincial and colourless' with 'no broad stream of intellectual life'. He admitted that city life in Australia could be treated satirically but declared that 'it's a poor game satirising one's own country for the entertainment of another'. ${ }^{35}$

It was true that Palmer had not published a city novel at the time of his interview, but a draft of The Swayne Family had existed for several years. In his letter to Wilmot, Palmer mentioned that he had completed a 'solid' novel of 'Melbourne life'. It appears that Palmer began writing this novel in 1924 when the disappointing response to the Pioneer Players was still a recent memory and although it was never published, it formed the basis of The Swayne Family. Indeed, the origins of the novel can be pushed back even further. In 1934 Nettie Palmer wrote that The Swayne Family, in one form or another, 'has been in his [Vance's] mind ever since I've known him'. ${ }^{36}$ She also noted that the Swaynes were like a number of families she and Vance had known in Studley Park and Kew. At about the same time Palmer noted that he had first imagined the leading character of the novel, Digby Swayne, at Abbieglassie in $1909 .{ }^{37}$ His character was suggested by the figure and bearing of Digby Denham, the Premier of Queensland, who travelled on the same train as Palmer when he was a teacher at Glayfield College. Esmonde Higgins was another model, in this case for Digby Swayne's rebellious son, Ernest. When Nettie informed Esmonde of this fact, she went on to clarify the aims of the novel. She declared that Esmonde's 'approval of The Swayne Family and its astringent satirical outlook was very welcome: most readers are so circulating-library that they simply don't notice anything except the course of the very secondary love-story in the book!' Nettie re-affirmed that the novel was an attack upon Melbourne: "If Vance had written, as author, "Melbourne is wowser \& thickheaded", that might have been noticed as an attack; but since he puts his views into the situation or into the mouths of different persons, they are ignored.' 38

In The Swayne Family, Palmer intended to confront the comfortable suburbanites whose contempt for art and ideas supposedly made 


\section{Dream and Disillusion}

city life in Australia a mean affair of cheap aspirations and secondhand ideas. The concerns of the novel also enabled Palmer to draw more directly than in any of his previous novels on the experiences of the writers, rebels, socialists and civilisers with whom he had associated since young manhood. Accordingly, themes which had been passed over as mere biographical detail in his previous writings invited elaboration: Moreover, Esmonde Higgins's character gave extra scope for such an endeavour, for his intensity, thirst for conviction and intellectual curiosity afforded a lively contrast with the emptiness Palmer found in middle-class Melbourne. While an 'astringent satirical outlook' was appropriate to the novel, it is not hard to see how some readers misread it, for Palmer's tone is quiet and the satire oblique, despite some rude comments about Melbourne.

Digby Swayne, the key figure of the novel, was a retired businessman who had spent a period of eight years in conservative politics, two of them in the ministry. At the age of seventy-three he had gone to Europe for a year and at the outset of the novel was about to rejoin his wife Margaret, his two daughters, Kathleen and Dorothy, and his two sons George and Ernest, all of whom lived in Melbourne. Swayne had entered business in the early I8gos and had since prospered. When the war broke out he became a vocal patriot who regretted that age prevented him from answering the Empire's call. However, he gave his son Steven who was killed. Towards the end of the war Digby Swayne had resigned his ministry when his brother, who opposed war and conscription, was charged for printing unauthorised anti-war pamphlets. In the years after the war, Digby Swayne grew firmer in his defence of family life: 'The one thing that gives life meaning and continuity'. ${ }^{39}$ With the arrival of the depression Swayne was proud of his relative economic security, yet troubled by the signs of economic collapse, proud of his resilience, yet dubious about his health, an advocate of a close-knit family life, yet a man concerned by the gradual break-up and dispersal of his family. For all his worldly success, Swayne emerged as a failed, emotionally inadequate man.

Despite very different settings, there are similarities between The Passage and The Swayne Family. Both novels explore integrity and falsity. Hugh Callaway and Digby Swayne in their different ways both followed false ideals. While Hugh was anxious to escape the Passage for a more stimulating life in the wider world, Digby had fled from the rough-and-tumble character of Jaffra, the 


\section{Vance Palmer's Writings}

country town of his birth. His possessive attitude to his children, large home and respectable business associations all fortified him against unpleasant memories of Jaffra and shielded him from the disordered world about him. This style of life generated rebellious feelings in the children, particularly in Ernest, the youngest son, who deplored the essential mediocrity of his father's aims and attainments. As a young man in search of life's meaning Ernest developed his talents as an artist and later left Melbourne to rough it for a time away from the city. His quest led him to Jaffra where he was briefly employed by an old farmer who as a boy had taunted the young Digby Swayne. Ernest's coincidental return to Jaffra emphasised how unenduring Digby Swayne's achievements had been.

While it is clear that Digby Swayne's world had crumbled there is little in the novel to suggest that his children would create better lives for themselves. Although more open, George and Dorothy were almost as futile as their parents. Ernest and Kathleen were, as Nettie Palmer described them, 'the only growing parts of that family'. ${ }^{40}$ Yet the uncertainty of their future also suggests that by the I93os Palmer was more struck by the forces that would falsify the third generation of Swaynes in Australia, than those that would deepen their lives. The problem was compounded by the fact that it was more plausible to suggest that a Hugh Callaway should return to the therapeutic rhythms of the natural world, since they were part of his immediate background; than it was for George Swayne, a solicitor, to do so, or Kathleen, a post-graduate student in philosophy, or Dorothy, a wife and amateur actress, or Ernest, an engineering student turned artist. Palmer's traditional solutions to false living seemed ineffectual when applied to the circumstances facing Digby Swayne's middle-class offspring. A familiar solution of a kind was found for Kathleen, who was prepared to drop philosophy and marry Svenson, a student of agricultural science who owned an orchard in the country. Like Maynard and Lew Callaway before him, Svenson met critics of his life style with a common rejoinder in Palmer's fiction which was always supposed to silence criticism: 'There's no hub or centre in life except the one you make for yourself.' 41

Ernest's future was less easily settled. Indeed, it would appear that Palmer had some difficulty knowing what to do with him, for the novel is half over before he is fully introduced. The relevant scene is set in a Lonsdale Street café, where Ernest was entertaining 


\section{Dream and Disillusion}

several of his fellow artists on the money he had received from a caricature of his cousin, a politician. With the claret flowing freely, the discussion turned to the real meaning of Ernest's cartoon. He was asked if the caricatured politician was meant to be a symbol of his party. 'No', he replied hotly, the cartoon represented himself, his friends and the citizens of Melbourne. His target was life 'without any inner spark' and the lives of people who had 'lost their guts and become bits of mechanism'.42 The mechanical gestures and the deadness of his cousin had appalled him. He wondered if there was 'something in the life around him that reduced him to an automaton?'

Was there something about the town itself, with its dull, middleclass dignity, its geometric streets, flat suburbs, featureless surroundings, that sucked all the passion out of people except the passion for conformity, making them shrink from what was violent or eruptive, wrap themselves in protective conventions, suspect any activity that hadn't a commercial aim? ${ }^{43}$

Palmer would probably have endorsed this vigorous polemic. $\mathrm{He}$ did feel that there was something in 'the town itself' which made its inhabitants dull and conformist. Yet such an attitude could easily become an excuse for dismissing both the attractions and meanness of the city, a limiting outlook for a novelist who claimed to be interested in the common people and who sought to interpret Australians to themselves. Though a popular enough convention among Australian writers, Palmer's stark caricature of the city as unrelieved suburbia was a narrow bias which reduced the scope of his novel and may help explain why he made so little of Ernest.

It soon becomes apparent that Ernest did not have very developed views about either his art or his future. He felt that his fellow artists had withdrawn from the life about them into their own secure world where art shows, concerts, the publication of new books, were events of consequence. This world did not satisfy him: 'Was it that he had never believed in art as an end in itself? Or merely that his own impulse to create came from the conflict between the values around him and those he was discovering for himself?'44 Ernest had never been confident as an artist, partly because he distrusted the stodginess of the Swayne temperament, but he also wanted to experience other ways of living. It was this impulse which attracted him to Connor, a 'racy-tongued, combative' individual who 'revelled in the idea of being one of the insurgent mass of 


\section{Vance Palmer's Writings}

workers struggling towards power' ${ }^{45}$ Ernest became increasingly impatient with imprisonment within his own class background and finally resolved to leave Art, Melbourne and the family with Connor. He was tempted to 'get outside himself', to 'look at reality from a new angle - cell in gaol or camp of deadbeats along some inland river'. ${ }^{46}$ However, little of consequence happened to Ernest in the country and he gradually fades into the background of the novel.

Palmer's lack of sympathy with city dwellers, particularly the Digby Swayne's of Melbourne, is more understandable than his diffident treatment of Ernest Swayne. While Palmer was under no obligation to reproduce Esmonde's life in detail or even offer a likeness of him, it was characteristic that Ernest should be a less complex and less articulate character than Esmonde Higgins. In the r 920 , Esmonde emerged as an articulate, well-read, university educated member of the Communist Party. Ernest was a more instinctive, less articulate and less political character. Moreover, while Esmonde had gone to Oxford after the war and had visited Ireland and Russia, Ernest left Melbourne to 'look at reality from a new angle'. This 'new angle' was not one Esmonde would have chosen. Indeed, he had turned aside from Palmer's style of nationalism (and from the pseudonym 'Sliprail') as his interest in Marxism grew stronger. Although Palmer's distrust of ideas had lessened by the time he was writing the final draft of The Swayne Family, he still felt uncomfortable with a figure like Esmonde Higgins for whom debate about man and society was as important an aspect of day-to-day life as scaling fish was to Lew Callaway. Even so, Palmer's diffident treatment of Ernest was consistent with his reluctance to draw upon experiences from his own familiar world of journalism, minority socialist and literary groups and radical causes. Palmer seemed to feel that experiences of this kind were not allowable in an Australian novel, an unfortunate inhibition, particularly in combination with his narrowing, anti-city prejudices.

There is room to dispute Palmer's handling of key themes in The Swayne Family, but the obvious moralising had been reduced, along with the often stereotyped characterisations of women, which marred much that Palmer published in the 1920s. In fact, Kathleen and Dorothy Swayne are, if anything, more subtly portrayed than their two brothers. The greater sophistication of The Swayne Family arose from the progressive refinement of Palmer's faith in the relatively simple virtues of manliness and the integrity of the 


\section{Dream and Disillusion}

natural man. By the late I 920 s his strident emphasis upon the robust virtues of novels written for men appeared affected. Particularly during the depression, confidence in the self-sufficiency of this world began to falter and once secure assumptions grew more uncertain. In this atmosphere of pervasive unease, Palmer's outlook grew more complex. Old beliefs were stated more cautiously, while new ones were difficult to acquire. Some of the consequences of this change are evident in Legend for Sanderson, a novel which traces a young man's efforts to accept his family background and find an honourable livelihood. While Neil Sanderson arrives at a measure of self-awareness, it is clear that the process was a more difficult one than in any of Palmer's previous novels. This is hardly surprising in a novel written in the shadow of the depression, when Palmer was concerned by the rise of fascism in Europe, the course of the Spanish Civil War (Palmer wrote some of the novel while he was in Spain), the prospects of a coming world war and the narrow and evasive conservatism of the Lyons Government. While these events do not bear directly upon the novel, they altered assumptions about men and society which had shaped Palmer's earlier novels.

Two characters dominated Neil Sanderson's imagination. His father, an extravagant and unscrupulous contractor and former cabinet minister who died caged, drunk and rebellious at the re-opening of his hotel and Leo Besanck, a White Russian who was fond of books, but impatient with work. Neil Sanderson went through several phases of development in his efforts to adjust to his father's memory. After quarrelling with him, he left his engineering course to become a cane-cutter. $\mathrm{He}$ imagined that he would become 'a leader of the working-class' dedicated to depriving men like his father of their power: ${ }^{47}$ This desire weakened when his father died. Sanderson then thought that he would rather enjoy a casual existence moving from job to job without responsibilities, but this phase also passed as he began to value what 'separated him from the mass' ${ }^{48}$ With his working-class identification behind him, Sanderson bought a fishing vessel which enabled him to be his own boss. Friends noticed that he was growing no less self-centred than his father had been. Yet after personal troubles and a serious illness, Neil Sanderson developed a more balanced view of his past. He saw his father's deficiencies more clearly and resolved to avoid them. He rejected the chance of joining the big business interests of the town for a more humble partnership with an old boat builder whose business was threatened by the exorbitant prices demanded 


\section{Vance Palmer's Writings}

by the big mill owners. Neil Sanderson became neither a workingclass hero nor a primitive capitalist like his father. He found his level in a small-scale business which demanded a degree of craftmanship. At almost every stage of his development Neil Sanderson was influenced by Leo Besanck. His sceptical intelligence continually reminded Sanderson of what was merely boyish bravado or falsity in his outlook upon life. Besanck was one of Palmer's more successful characters. But he was also something of rarity in his fiction, for he was a questioning individual, rather than a man who lived more elementally by sense and instinct. It is a commentary on the inhibiting assumptions underlying Palmer's view of a national culture that a cosmopolitan character of Besanck's type should appear so late in his fiction. It might also be argued that Besanck's appearance coincided with Palmer's growing awareness that Australian developments could not avoid being profoundly influenced by events in Europe.

At successive stages in his literary career Palmer had been forced to broaden and deepen his account of character and environment. By degrees, the stereotyped characters of 'The Bridge' gave way to figures whose inner lives were more fully drawn. Yet this development met some resistance from Palmer, for his suspicion of intimacy as something 'feminine', falsely introspective, English and ineffectual persisted. He felt that it was a betrayal of his integrity as a writer to commit himself too fully to such a world, for to do so would compromise his ideal of a distinctively egalitarian Australian democracy with its male aura of 'impersonal interest'. The ensuing tension between an encroaching female world and an increasingly constricted male world was complicated by Palmer's further need to recognise the role of ideas in explaining how individuals grasped the problematic world about them. The practicalities of station life became an increasingly inadequate basis for Palmer's fiction. While The Swayne Family and Legend for Sanderson broke from this tradition, they did not entirely escape it. The pressure of events may explain why Palmer left the novel for such a long period after Legend for Sanderson, but it might also be argued that by the late I93os Palmer had reached a turning point in his career as a novelist. From around the mid-rg3os Palmer's development depended on his ability to transform the natural landscape of his outback novels into a more explicit historical and social setting. It took time and a new level of historical awareness aided by the histories of Brian Fitzpatrick to effect this change. The Swayne Family and Legend for Sanderson 


\section{Dream and Disillusion}

begin the process, but it found more conscious expression in the play Hail Tomorrow, the Golconda trilogy and The Legend of the Nineties. While Palmer's handling of the historical setting of his novels increased markedly between The Man Hamilton and Golconda there is not the same development in his portrayal of the inner consciousness or moral awareness of his characters. While the key figures of the Golconda trilogy are generally more convincing than Palmer's earlier portraits, they nevertheless lack immediacy. The impression remains that Palmer never overcame his awkward withdrawal from intimacies which a franker and more skilled novelist would have relished.

Golconda, Seeditime and The Big Fellow are Palmer's most accomplished novels. Their range is more extensive and they are not marred by the obtrusive partisan feelings which made Hugh Callaway so unconvincing a character. It is clear that between The Passage and The Big Fellow Palmer had submitted his ideas about the spirit of community to more sceptical analysis. Christy Baughan, the gouger with memories of Paraguay, was one of the fruits of this long reflection. Christy had a comprehensive view of the world men should aspire to build. He once told a collection of gougers that the silent world around them 'sends out a message to us to humanise it, steep it in our affections, rear children on its lean soil who will cherish it, not exploit it; make it blossom not with iron derricks tearing out its riches for others but with the fruits of true comradeship'.49 The audience were understandably a little wary of such effusions from a man who was old, isolated and somewhat erratic in his behaviour. But doubts also assailed Christy Baughan. He could not look back upon his last days with Lane without wincing at the intolerance of his teacher and the disputes and antagonisms which had divided their small community. Despite his passionate fluency about the prospects of the new community, Christy feared that the world was not as he had imagined it: 'there might be forces in it uncontrollable by the will of man, perhaps hostile to him, outwitting him, using him to his own hurt'.50 Although Christy grew weaker and more erratic the idea which had moved him took on different forms in other people's minds. The sculptor Neda Varnek sought to capture Christy's spirit in stone, the school teacher taught her pupils to know their surroundings and Macy Donovan, the trade union organiser, was moved to defend Christy from his detractors. Lane's new Australia was not the only image of compromised perfectibility in the trilogy. 


\section{Vance Palmer's Writings}

There were smaller groupings like the family and the ideas which attached to it and marriage. Hugh McCoy's reflections in The Big Fellow recall Palmer's sentiments of 1910 about the need for people 'to love one another with the very breath of their souls and be kin in thought and dream'. McCoy had had a similar ideal but had come to wonder if it was oppressive, 'checking the spontaneity ... in a life that was merely mortal'. McCoy's scepticism enabled him to escape a tyrannical ideal, but it also prevented him from living as fully as he would have liked: 'All his days he had been plagued with half-beliefs, half-desires, loyalties that his reason rejected but that held a secret power over his spirit. It had kept him from being certain of himself.'

'Dependable enough, but dry, he reflected wryly, looking along the bookshelves.' 51

Macy Donovan was a more impulsive, opportunistic and worldly individual than McCoy. He had worked his way up from tradeunion representative on Golconda to become the Labor Premier of Queensland. According to Sol Encel, Donovan approximates a persistent caricature of the politician in Australian fiction; 'the upright man too good for the dirty game of politics'.52 It would be more useful to place the political dimensions of Palmer's story in the broader context of man's search for wholeness through 'true comradeship', art, marriage, wealth or power. It is true that Donovan looks beyond politics and his marriage to a life with Neda Varnek, yet the point is not that politics is dirty, but that politics fills only one dimension of Donovan's search for wholeness. Neda Varnek reminded Donovan of his early days at Golconda and the ideals of Christy Baughan. She also made him aware that her more fluid and poetic grasp of life differed from his own, a realisation which had always tantalised and troubled him. Yet shaping the individual's search for wholeness, either immediately or at several removes, was the question of how men were to organise their lives, a question sharply posed for those who knew the wealth of Golconda and argued about how or by whom it should be used. In the trilogy there were fewer allusions to the therapeutic possibilities of the natural world than in an earlier work like The Passage and more concern to understand the elusiveness of harmony and completeness and how these and similar ideals could act both as a snare and an inspiration to men.

The Legend of the Nineties is among Vance Palmer's best known works, although many readers would be surprised to learn that he 
regarded his book as a revisionist exercise designed to bring the I 8 gos into perspective. In 1954 Palmer told a radio audience that he disagreed with those who regarded the nineties as 'a golden period for the Arts', a time when 'political thought and experiment flourished as never before' and when 'Australia as a nation came into being'.53 However, the false impressions Palmer wanted to correct fall short of a searching indictment of the period. One of his main arguments was that the 1890 s was a time of sharp social conflict which put an end to many of the more extravagant hopes for a utopian Australia ideally secluded from the old world. While Palmer pointed out that many of these hopes proved false and were often narrow and exclusive, he also found much to praise in the utopian impulse. Indeed, there were contradictory motives in Palmer, for while his intellect told him that this utopianism had often been intolerant and naive, he nevertheless felt emotionally attracted to it. Accordingly, his criticism of the legend invariably registers less strongly than his praise. It is also true that Palmer was reluctant to lessen the drama of his story since he feared that the Australian past was too often regarded as merely drab and unexciting. After reading R.M. Crawford's Australia in 1952, Palmer wondered if 'our record is as tame and lacking in passionate impulses or high ideals as it seems in cold print'. He conceded that Crawford did not share this view but thought that his stress upon the 'strong and resilient tradition of practical and experimental compromise' in Australian politics was unfortunate; it made for an inadequate rendering of the human drama. It tends towards a certain flatness of tone, a presentation of life without either its turbulence or creative zeal. ${ }^{94}$ Palmer was still anxious to dispel the idea that Australia was a dull backwater where human beings lived stunted lives.

Many of Palmer's more familiar guiding assumptions about creative growth recur in The Legend of the Nineties. As pointed out in earlier chapters, a number of these views accord closely with the attitudes of $\mathcal{N e w ~ A g e ~ c r i t i c s ~ w h o ~ d e p l o r e d ~ t h e ~ n a r r o w n e s s ~}$ of the respectable classes and their feeble drawing-room culture. In similar terms Palmer tells of how the folk-imagination of the Australian people began to develop once they had come into contact with the broadening influence of the native soil. He stressed 'the real possession of the country' in terms that recall Edward Carpenter and wrote of the 'oral songs and stories', which were the 'first signs of a new people's birth'. ${ }^{55}$ It remained central to Palmer's argument that self-discovery was necessarily collective and dependent 
upon an intimate knowledge of the Australian environment. This was evident when he wrote that the significance of this 'dream-time' around the 1890 s 'was that it turned the eyes of Australians inward and impelled them to discover themselves and their own country'. ${ }^{56}$ According to this view, the individual found himself by emphasising the communality of his experience, while the writer succeeded in so far as he was in sympathy with the workings of the 'mass imagination' of the people. Palmer welcomed this situation and disparaged those for whom the balladists were 'crude, non-intellectual, poor in psychological interest', a 'superior attitude' which often concealed 'wastes of dullness'. ${ }^{5}$ ?

In The Legend of the Nineties Palmer argued that Australia's period of relative isolation from outside influences was beneficial, not a misfortune. He felt that arguable losses in sophistication and psychological penetration were more than compensated by the Australian writer's rediscovery of the spirit of community. While this period of isolation was progressively eroded and compromised in the twentieth century, Palmer maintained that the modes of thought which derived from the last decades of the nineteenth century continued to stimulate the creative imagination in Australia. This outlook accorded with Palmer's often repeated view that the creative artist was obliged to stay within Australian borders and deal with the society about him, yet the seeming inevitability of this decision was invariably made more palatable by the further suggestion that, however stony this path proved to be, it remained the only sure way to creative vigour and integrity, aims which Palmer valued highly in the creative artist. Palmer would have rejected the criticism that constant stress upon the legend led to the false bravado of 'The Bridge' and a reluctance to explore greater and more intimate worlds or draw upon the supposedly derivative and therefore worthless lives of city Australians. He also paid little attention to the achievements of expatriate writers. These and other questions which bear upon the origins, adequacy and effectiveness of Palmer's ideas are examined in the conclusions. 


\section{I}

\section{Conclusions}

In the years before World War I, the main figures of this study saw before them at least two possibilities for Australian democracy: the servile state in which democracy existed in name only or a spirit of democratic community. The first Australia was pictured by its citizens as a world of growing uniformity; an artificial, characterless, machine-made world in which the working-classes would barter their existing freedoms for a measure of material security. In such a world the arts which men had cultivated through the centuries would wither and die. Debased, mass-produced entertainments would arise in their place. There were those who felt that these and similar changes for the worse were already evident in modern societies, including Australia. Writers of this persuasion felt that they were unable to achieve art in the debased modern world. The aspiring writer could either surrender to this impotence or he could rebel against the attitudes and social tendencies which he believed had kept him silent. The refusal to remain deferential to the parent culture was a vital emotion among literary nationalists precisely because it helped overcome their sense of cultural impotence. Moreover, this new assertiveness helped some writers to feel kinship with the ordinary people for it was sometimes thought that they too were refusing to remain submissive. The lethargy of the old bohemia as Louis Esson wrote of it, the inability to write and the lack of a national culture were thought to be symptoms of spiritual torpor and an exaggerated deference towards older cultures, whereas the urge to write signified the release of new energies and promised new alliances between the artist and the people.

In the pre-war years, then, it appeared to some that the authority of the old, bourgeois order was under challenge from the spokesmen of the new democracy. There was much that was vague about this sentiment, but cloudy sentiments and misconceptions can excite strong emotions. What is more noteworthy is that those converted to the cause of the emerging national culture had rejected the old 


\section{Conclusions}

order before it had been overthrown. Moreover, they spoke of the new democracy which was yet to emerge as if it already existed. In this situation, their perceived social position was an ambiguous one: they did not consider themselves to be middle-class, yet nor were they full members of the new democracy. They were transitional figures awaiting the transformation of their society, and an end to the ambiguities surrounding their national identity. However, Australians were soon involved in a patriotic war against Germany, rather than a battle between the 'two Australias'. The war did not bring about the desired social transformation. Indeed, while the war revealed the division and the confusion of those who had wanted to transform their society, it provided a noble cause for those who felt that the stern challenge of war was the ultimate test of a nation's moral worth. W.H. Fitchett, for example, who before the war had opposed just about everything that Palmer and Sinclaire had hoped for in a new Australia, was converted to a brand of Gallipoli patriotism during the war. Fitchett had become a proud Australian:

It was reasonably certain, if only on racial grounds, that the Anzac lads would meet the rough challenge of battle with high courage; for they came from a fighting stock. But no one could tell how far modern conditions had affected ancestral qualities; still less could it be determined how far men of the British race had been affected in the aptitude for war by the circumstances that they had grown up on strange soil, and under strange skies. But any doubt as to the capacity for enduring hardship, for facing death - the fighting efficiency, in a word - this new type of the British race may have was settled for ever by the story of that historic Sunday morning. ${ }^{1}$

Fitchett was prepared to accept the idea of a distinctively Australian identity once he felt assured of the fighting ability of Australia's brave 'lads'. Palmer, Sinclaire, Wilmot and Esson held a different view of the significance of the war. They were alarmed by the patriotic excesses of the governing classes. They were convinced that Hughes was more likely to discredit Australia than the common soldier and justified their fears by referring to the repressive powers of the War Precautions Act and the attempts to impose conscription. They resisted the idea that the war was the consuming issue for Australians. When conscription was defeated it appeared to radical members of the Melbourne literary community that the Australian people had spoken for democracy, but they were also delighted at 


\section{Dream and Disillusion}

Hughes's frustration. After the second defeat of conscription a party was thrown to celebrate the event. Sinclaire arrived hugging two bottles of champagne and left towards the end of the evening behaving as if he had had them both. Not long afterwards Vance Palmer was helped into Guido Baracchi's city flat where he spent the night recuperating. ${ }^{2}$ Yet although reassuring, the defeat of conscription was a negative victory for Australian democracy. Palmer and Sinclaire had both hoped for more positive achievements.

After the war Palmer declared that Australian society had become urban and bourgeois. He wrote of Australians as a commerciallyminded people who were too easily reconciled to the spiritually cramped and inadequate life of the city. Palmer felt that this had not always been true of Australian society, least of all in the 1890 . Although Palmer's ideal of an original new democracy receded, it did not disappear, but was transformed into a haunting dream of what Australian society might have become if it had honoured the spirit of the I $890 \mathrm{os}$. As the reality of this hope died, the dream of what might have been and of what might yet be if Australians underwent a change of heart, grew more alluring. Palmer could not reconcile himself to urban Australia nor rid himself of the legend of the I 890 os. It was disconcerting for a man who wanted to deal with a simple down-to-earth world to remain troubled by the ambiguities of being Australian and haunted by notions of a lost past. Yet Palmer persisted with the view that Australian literature should be known for its manly vigour. He believed that the literature of a degenerate, servile society would grow increasingly introspective, morbid and indifferent both to the 'real world' and to the aspirations of ordinary people. It would become the plaything of cliques and coteries, whereas the art of a more truly democratic society would be robust, energetic and at ease with ordinary people. Doctrines of this kind made it all the more difficult for Palmer to write about his own world and that of his friends.

The complaint that Australian society had become bourgeois helped Palmer to shift any personal responsibility for creative failure onto his society. In the post-war years he was inclined to view himself as a man trying to cultivate healthy cultural principles in a sick, falsely complex society. He was inclined to argue that he was no more to blame if he failed than a gardener would be if his plants were stunted by poor soil and a harsh climate. When Palmer complained that Australian society had become suburban he was insisting that the creative climate was indifferent to nationalist 


\section{Conclusions}

ideals whereas it had once shown signs of being more favourable to them. Given this bleak outlook, how did Palmer view the literary task ahead of him? He felt that he could bid farewell to the I 89os and adopt instead the commercialised standards and frenzied tempo of his own society or he could remain loyal to the spirit of the I8gos in the hope that the tempo of Australian society might change and that he might: influence the change. Palmer preferred the second course although he felt that it bound him to a demanding ideal of artistic integrity in an unappreciative society. He felt confined by his society and limited in artistic scope, yet he also felt that he had to resist any temptation to appeal to the 'suburban' tastes of his day. These aims were difficult to reconcile artistically as well as personally. It is difficult, for example, to reconcile Palmer's frequent allusions to vitality with the often soporific influence of his prose or his celebrations of robust manliness with Nettie's frustration at his rather distant and patriarchal bearing towards her.

Palmer maintained that Australian writers should cling to the traditions of the I 89 os for in doing so they might more effectively resist the corrupting influences of the post-war world. In this way, loyalty to the 18 gos and in particular to the spirit of Lawson and Furphy became a sign of virtue. There could be no richer compliment than to place a writer within the 'Lawson-Furphy tradition' or suggest his affinity to the Bulletin of the 1890 s. In the name of this tradition Palmer felt justified in his largely dismissive attitude to post-war urban society. He was also able to adopt this tradition as a protection against literary modernism, for to indulge in experiment suggested a lack of faith in the literary experiments of Lawson and Furphy. Since Palmer also warned against introspection, his enclosure within a confining tradition which no longer had popular support was almost complete. The only justification for remaining so imprisoned was the belief that the writer was preserving a live tradition which would blossom at some unspecified time in the future. This view tended to rest on the hope, or the fiction, that in their heart of hearts the Australian people wished to rediscover their more genuinely Australian. selves. According to this view, middle-class institutions and the bourgeois mentality were not as deeply rooted and pervasive in Australian society as might appear. There was much that was evasive, vague and distorting in this view of Australian society. Moreover, it jeopardised the artist's right to develop his own style and subject matter since it was considered far worthier to continue with the preoccupations of the 


\section{Dream and Disillusion}

I 890 s than to break away from them. In sum, the logic of the postwar nationalist argument ran as follows: the democratic ferment which was to have given Australian society a new lease of creative life faded into a stultifying suburban conformity. The writer, once a man of the people in touch with a receptive audience, became a man of the people hemmed in by a dominantly middle-class society. Whereas it was once reasonable to expect originality and vitality in the Australian writer, changed conditions, so the argument ran, limited the scope for these qualities. Instead, there was now a greater need for the sort of integrity which enabled the writer to uphold the dignity of his calling in the face of a vulgarised populace.

Arguments of this type attracted Palmer at a time when his imaginative writing was proving troublesome. He was caught between defeated hopes and a social reality which he found disturbing. His station writings of the I 920 s present static worlds cut off from the social concerns of the surrounding society. In addition, Palmer's damaging reticence about the imaginative and emotional life of his characters continued to inhibit the scope of his writing. Yet the nationalist critique enabled Palmer to attribute some of these shortcomings to the failings of his society. Moreover, it was an argument which comforted those who believed that their gifts were greater than their achievements, a reasonably numerous fraternity among writers, journalists, academics and students. It also comforted those who professed radical beliefs, but who maintained bourgeois appearances.

These comments may sound harsh, but they are a necessary corrective to the view that loyalty to that particular version of the Australian ethos commonly associated with the 1890 os was necessarily liberating and expansive, both for the artist and for his society. It is also worth recalling that there was little in Palmer's writing which gave offence to the middle-class public he criticised. In terms of style, content and morality his novels were more discreetly inoffensive than one might have expected from a man who had declared his opposition to the timid morality of drawingroom society. As a critic of the middle-class Palmer was far more subdued than H.L. Mencken in America and as a novelist he was far less provocative than his English contemporary, D.H. Lawrence. That The Passage became prescribed reading for Australian schoolchildren is striking proof that Palmer's writing was entirely acceptable to the conservative arbiters of adolescent morality.

By the r920s, Palmer's ideal of an ordered democracy - guild 


\section{Conclusions}

socialism modified by Australian tonings and bush manliness seemed to have changed from a realisable future into a lost hope. Divested of its promising future, Australia seemed no better than a rather shapeless and unoriginal society. It did not appear to run to redeeming vitality or notable originality. Those who had once hoped that an emerging national culture would save them from anonymity and boredom had to find new ways of coping with their ambitions. The key figures of this study met this problem in varying ways and with varying success. Louis Esson made a serious bid to establish an Australian theatre. When this scheme collapsed he retreated reluctantly to journalism, but was soon overtaken by an enervating contempt for Australia and the post-war world in general. Unlike Palmer, Esson found no sustaining Australian tradition or legend of the I8gos. Frederick Sinclaire moved from his position as a free-lance theologian with few institutional connections into more formal teaching engagements with the university, finally to accept a chair of English in Christchurch, New Zealand. Although Wilmot was influenced by the ideals of the emerging national culture he was not as emotionally committed to the creation of a new social order as Esson, Sinclaire or Palmer. He had made writing, producing and selling books into a lifetime vocation which demanded a measure of creativity, craftsmanship, critical acumen and commercial competence. This embracing concern for books, including regular employment in Cole's Book Arcade and later as the manager of Melbourne University Press, gave Wilmot a pragmatic middle ground between social prophecy and concern for Literature which Esson and Palmer lacked. The 1920s was the period of closest association between the Palmers and the Essons. They worked together on the Pioneer Players and supported each others' efforts to secure greater local recognition for Australian writing. In the 1920 settie Palmer devoted much more of her energy to the cause of Australian literature. It is possible to discern in these efforts a shift away from discussions of national consciousness and the emerging national culture to the more explicit promotion of Australian literature. This 'promotional' drive, which was associated with arguments about the distinctiveness of Australian literature and society, may have been intensified by growing economic pressures upon free-lance writers. Vance Palmer, Louis Esson, E.J. Brady and Harrison Owen were instrumental in starting the Australian Authors' and Writers' Guild in 1915 which aimed to limit the influx into Australia of syndicated stories and articles. ${ }^{3}$ 
The Bulletin sympathised with the aims of this 'earnest group of literary-trades unionists', but the guild, like the Bulletin's own Australian Academy, had little success and soon collapsed. ${ }^{4}$ Even so, opposition to syndicated materials continued through the I920s as did the parallel pressure for a higher Australian content in local newspapers and magazines. Despite these efforts Nettie Palmer maintained in the 1920 s that conditions for the free-lance writer had grown tighter. ${ }^{5}$ Even so, the end of the r 920 saw the first Australian and New Zealand Authors Week, the formation of the Fellowship of Australian. Writers and the announcement of the Bulletin novel competition. In their different ways, each of these events indicate the efforts made during the 1920 s to improve both the status of Australian writers and their material conditions, causes which helped absorb the energies of those who had once hoped for more fundamental changes in the cultural life of Australian society.

In the rg3os the anti-bourgeois aspects of the Palmers' thinking were more explicitly involved with left-liberal causes than in the 1920s. These involvements linked them and other Australians with the wider European anti-fascist movement. They spoke out against the evasive conservatism of their government, they became office bearers in voluntary left-liberal organisations; they helped organise and also addressed public meetings; they joined deputations, signed petitions, wrote letters to the newspapers and produced pamphlets and articles which drew attention to the fascist tendencies of the modern world. These activities, along with their sojourn in Europe, gave an air of breadth and cosmopolitanism to the Palmers' nationalism. By contrast to the I920s, the tempo of their lives appeared to increase. They were now better known and more people and more causes required their time. Moreover, their voices became known to radio audiences, although they had once looked upon the wireless as part of the tawdry gadgetry of the twentieth century. Yet evidence of an increasing implication in European affairs, along with an adjustment to city living and its increasingly sophisticated technology, should not be regarded as a sign of happy adjustment to a more complex and cosmopolitan world. Adjustment to new conditions may have seemed necessary, even inevitable, but the Palmers could not help feeling that the experience would be a demeaning one. They continued to remind themselves and their public that worldliness should not be mistaken for wisdom and that a faster tempo of life did not necessarily create more enjoyment or worthier literature. 'Your two parents', Nettie Palmer 


\section{Conclusions}

confided to her daughter, Aileen, in. I943, 'happen to be more powerful than in years past, mostly by the effluxion of time and by the fact that the time has been passed in the city, where reputations are made, instead of in the country, where real work is quietly done'. ${ }^{6}$

These concluding observations have dealt, among other things, with the question of creative growth, a subject. which recurs in discussions of the Australian mentality whether revealed in literature or on the more informal beliefs of the society. I have suggested that Vance Palmer, a spokesman for the radical-democratic stream of the national culture, may well have become trapped within the assumptions and loyalties of a tradition which he believed was liberating for the artist and his society. In short, he became a spokesman for an ossified tradition. It does not follow from this observation that Palmer was wilfully narrow or that he conspired against literature or civilised values in Australia. But nor is it inconsistent to argue that while Palmer often advocated a livelier cultural life in Australia, many of his Australianist assumptions dulled the effectiveness of this advocacy. This judgment still stands after due attention is paid to Palmer's opposition to censorship, his concern for civil liberties and his criticism of a subservient colonial mentality in Australian life. The need to define the limitations of Australian life and if possible remove the causes of concern which preoccupied the key figures of this study and a number of their friends and followers, has persisted in much of the writing about literature and society in Australia. As this study has suggested, the problems they saw and the solutions they found were profoundly influenced by cultural debates which were not peculiar to Australia, but which nevertheless had Australian ramifications. Before commenting further on this question, however, it is worth looking briefly at some recent discussions of the character of literature and society in Australia.

In An Australian Perspective the historian, R.M. Crawford, criticised those who found Australian life 'commonplace'; a stereotype which he attributed to the misleading view: that Australian society was 'reduced, by a jealous democratic disapproval of distinction or difference, to the dull mediocrity of an immense suburb ...' ${ }^{7}$ Crawford maintained that this view overlooked 'the strongly aristocratic pattern of much Australian social history' and ignored the fact that a 'thinness of the life of the spirit' was a phase through which most colonial societies passed: ${ }^{8} \mathrm{He}$ regarded the evident 


\section{Dream and Disillusion}

quickening in the arts, in government and in scholarship during the 193os as the beginnings of a new maturity. Despite these signs of optimism, Crawford felt that it was still too early to expect a notable originality in the intellectual life of the community and he criticised those who complained that their own exaggerated standards had not been met. Rather than search for works of enduring worth, Crawford preferred to assess the Australian 'type of mind'. $\mathrm{He}$ approved 'the easy slouch, the astringent irony, the direct look, and behind these things, the awaiting and unlimited expectation' of the Australian for he believed that these qualities would 'leaven the mediocrity that is in his as in any other community'. ${ }^{9}$ According to Crawford, Australian society was more complex than many observers made out and the prospects more encouraging when viewed in the proper historical context. Although crisply argued, An Australian Perspective relies rather too heavily upon a mechanistic division of Australian society into cultural phases each of which corresponds, or is made to correspond, to the known phases in the life-cycle of a colonial society. This affords a tidy view of Australian society and is an aid to fluent narrative, but it avoids some of the trickier problems of cultural history. How were the phases of a colonial society to be recognised? How were the distinguishing characteristics of particular phases established and what caused them to change? What relationship did the colonial society have to the metropolitan culture? How did creative writers cope with the 'immature' phase of their culture? Moreover, if Australian society had suffered from a 'thinness of the life of the spirit', might it not be legitimate for a critic to find something 'commonplace' in such a society?

H.P. Heseltine has also examined the thin life of the spirit in Australia. ${ }^{10} \mathrm{He}$ questioned the adequacy of the 'democratic theme' as the key to the Australian imagination. 'If our literary heritage', Heseltine wrote, 'offers us nothing but the simple virtues appropriate to a simple frontier society, what can we do but reject it? We are left with a heritage which is an empty inheritance'. Later in the same article he wrote more agitatedly: 'Is our tradition, after all to be summed up in this or that single word - Mateship? Landscape? Nationalism? Is what we have received from the literary past so thin that the simple labels do, in fact, suffice?' Heseltine wanted a richer inheritance than the old labels seemed to provide. He wanted to re-construct the literary heritage in a way that would 'do justice to whatever discoverable complexity and force are latent 


\section{Conclusions}

in it', but without rejecting its 'Australianness'. Within nine pages Heseltine had produced a new formulation of the literary heritage. The old labels, among them egalitarian democracy and nationalism, were now a façade behind which loomed 'the fundamental concern of the Australian literary imagination': 'to acknowledge the terror at the basis of being, to explore its uses, and to build defences against its dangers'. These concerns gave the literary heritage 'its special force and distinction' and guaranteed its 'continuing modernity'. In this way a thin and inadequate inheritance had been enlarged and rendered more complex.

Arthur Phillips found much to disagree with in Heseltine's article, although he admitted that the 'traditionalists' had 'lost their sense of forward movement' and were restating old ideas rather than formulating new ones. ${ }^{11}$ Yet Phillips's main concern was to account for and criticise Heseltine's dissatisfaction with the literary heritage. He argued that from the turn of the century there was a changed emphasis in Australian writing. The need for cultural maturity had replaced the challenge of hostile circumstance as the dominant Australian problem. While this new problem touched the intellectuals it did not, so the argument ran, touch the whole community as had the concerns of Lawson and Furphy. A state of divided loyalties developed: 'Many of our writers were deserting Australian patriotism for the patriotism of the artist'. These deserters were attempting to deny their heritage. Phillips gave them no quarter. They were class-conscious, aristocratic, snobbish, contemptuous of the common man, duped by the "heroic gesturing' of European literature and hostile to the community. Such accusations provided a tight defence against the intrusion of modernity and European literature. Indeed so tight that Heseltine was forced into an absurdly contorted argument about the early recognition of late romantic awareness in Australian literature. He, no less than Phillips, thought that it was essential to claim Lawson and Furphy for his own interpretation.

The exchange between Heseltine and Phillips neatly summarised differing attitudes to the 'legend'. Heseltine felt that it had become narrowing to the point where Australians had lost their points of contact with more complex European modes of thought. Although he tried to suggest that the legend merely needed to be re-interpreted, it was clear that Heseltine felt that the orthodox account of Australian values virtually prevented the writer and his audience from responding to European literature. In reply, Phillips insisted that 


\section{Dream and Disillusion}

one of the valuable functions of the legend was that it prevented Australian writers from becoming preoccupied with European fashions.

Doubts about the adequacy of radical nationalist accounts of the past were also expressed by Peter Coleman, the editor of Australian Civilization, a symposium published in 1962 . In his introductory essay, Coleman criticised the narrowness of many 'Australianist'. interpretations of the past, particularly 'the standard radical-leftist' views of Childe, Evatt and Fitzpatrick. ${ }^{12}$ These men and their followers were accused of having an 'obsession with the creative role of the Labor movement' and of underestimating 'the contribution of the middle classes, the churches, the universities, and non-radical reformist and liberal movements!' In Australian Civilization Coleman sought a more diversified account of the Australian community than the radical nationalists seemed to allow. His dissatisfactions were similar to Heseltine's although he found different ways to explain why Australia had been misrepresented.

Five years after Coleman's Australian Civilization R.W. Connell deplored the 'limited set of basic ideas' which had dominated 'social comment and criticism' in Australia. ${ }^{13} \mathrm{He}$ argued that most of these ideas were to be found in W.K. Hancock's Australia, a book first published in 1930. One particular mark of the 'Hancock tradition' was the stress given to 'the triple conjunction of egalitarianism, nationalism, and Labor'. Connell had some telling examples of often repeated 'images' of Australia. He observed that Hancock had used Lawson's lines about the rich and educated being educated down to illustrate the egalitarian character of Australian society. Connell found that the same lines were quoted by W.F. Connell, J.D. Pringle, Peter Goleman, A.F. Davies, and Sol Encel and were misquoted by Gordon Greenwood. Even R.W. Connell had once quoted them. There was also the allegedly egalitarian habit of sitting next to the taxi driver; rather than secluding oneself in the back seat. Hancock had not used this example, but Connell found that D.H. Lawrence had and that he was followed by J.D. Pringle, Donald Horne, Craig McGregor and R.W. Askin. Connell conceded that a number of the ideas which he attributed to the 'Hancock tradition' had been in the air before I930, but he nevertheless stressed the seminal importance 'of Hancock's Australia in disseminating these ideas. It would have extended Connell's argument if he had known that Hancock had been a member of 


\section{Conclusions}

Frederick Sinclaire's Free Religious Fellowship, a close friend of Esmonde Higgins and a co-worker with Nettie Palmer on the Public Questions Society at Melbourne University in $1919 .{ }^{14}$ In the years I 914 to 1922 Sinclaire's Fellowship published a number of articles which explored the relationship between national consciousness, socialism, labour and creativity. A number of the English and Irish sources for these ideas have been mentioned, but it is worth adding that similar ideas were in vogue among young writers and intellectuals in America. ${ }^{15}$ Furthermore, it is reasonable to suggest that Hancock's parties of initiative and parties of resistance, which has proved so persistent a notion, is a variation upon the theme of the two Australias; the one creative, original and truly Australian, the other sterile, derivative and suburban.

Connell's 'Images of Australia' was a version of the criticism that the character of Australian society was too often summarised by a handful of recurring clichés. Whereas Crawford maintained that a sounder historical perspective on Australian society was needed and Heseltine urged critics to look behind the façade of nationalism, Connell believed that a progressive trivialisation of social comment could only be overcome by a 'full-scale theoretical analysis of social organisation and change in Australia'. Until this work appeared there would be little hope of escaping the stale generalisations which he believed too often passed for social and cultural analysis in Australia.

In 1972 there was an attack upon the egalitarian tradition from a different quarter in Warren Osmond's The Dilemma of an Australian Sociology. ${ }^{16}$ Osmond concentrated his criticism upon Sol Encel's Equality and Authority. He accused Encel of internalising two clichés common to Australian intellectuals: 'that Australia has no history because it is a "naturally" egalitarian society, and that Australia has no basic conflicts and is a homogeneous society'. ${ }^{17}$ According to Osmond, the first assumption was of little value since Encel made no attempt to explain the historical roots of the egalitarianism which he attributed to Australian society. The logic of this assumption was that there was little for Australian history to explain in the way of social movements, political processes or the interplay of ideas. However, Encel was thought not only to be ahistorical, but asociological in that he failed to show what 'egalitarianism' meant to those who believed that Australia was an egalitarian society. In short, Osmond claimed that Encel used egalitarianism as an explanatory device, but without exploring how the concept worked 


\section{Dream and Disillusion}

within Australian society and without explaining his relationship to the sociological literature relevant to 'egalitarian historiography'. Osmond concluded his analysis with the sweeping lament that in Encel's hands 'Australia becomes a society with no life, no history, no conflict, no human problems or dilemmas'. ${ }^{18}$ Elsewhere, he called for 'the most critical re-examination possible of the received wisdom about "Australian reality" '.19

Humphrey McQueen also found much to criticise in the received wisdom about Australian society in the works of radical nationalists, particularly Russel Ward, Ian Turner, Geoffrey Serle and Robin Gollan. ${ }^{20}$ McQueen argued that the 'racism' and 'materialism' of Victorian England had intensified in Australian circumstances, rather than weakened. Moreover, Australia was not a victim of imperial oppression, but the pampered possession of capitalist powers. This combination of circumstances had produced a capitalist mentality which was further deformed by an aggressive racism. ${ }^{21}$ McQueen urged those who wanted a socialist Australia to abandon the view that the Australian people were inherently socialist. He could see no grounds for such a belief. Like Connell before him, McQueen maintained that Australian historians needed to develop a Marxist overview of their society, otherwise they would remain trapped within a sterile empiricism. In an eleventh hour confession in $A$ New Britannia McQueen admitted that he had been less successful than he had hoped in escaping 'old - left' assumptions. The new theoretical over-view would have to wait. Since the publication of $A$ New Britannia McQueen has described Australia as a 'closed' society which developed no 'internal critique' and was 'repressively homogeneous': Australian unionism was 'tame-cat', our sociology 'broken and tenuous', our liberal reformism a species of 'piece-meal social tinkering', our extreme Left atheoretical, our Communist Party non-revolutionary, our 'occasionally newer left' derivative, our artists 'rootless' and our radical historians uncritical of the past. ${ }^{22}$

Many of McQueen's criticisms of Australian society are a restatement in different language and in a new historical context of the old radical-nationalist discontent with the bourgeois character of Australian society. This discontent, as we have seen in earlier chapters, included persistent misgivings about the bourgeois reformist character of the Labor Party, although much of the socialist rhetoric which hedged such doubts owed more to notions of community than to class. As the ideal of community receded, the 


\section{Conclusions}

criticisms of the 'false' community of suburbia intensified. Those, like the Palmers, who did not succumb to the view that there was little hope for worthwhile change in Australia retained some faith that Australian conditions, including distance from England and local environmental influences, would weaken the hold of British bourgeois civilisation in Australia. They liked to believe that this result would open the way for a more genuinely socialist Australian future, although in the meantime they were able to describe their society as conservative, conformist and morally timid. As suggested, they were inclined to be vague and evasive about how this better society would emerge and in the process often appeared to be apologists for their society or at least reluctant critics.

The various writings alluded to suggest a pervasive unease among historians, sociologists and literary critics with many of the radical nationalist assumptions about the character of Australian society and the origins of its allegedly distinctive egalitarian political culture. Critics feared that the nationalist position had become the preserve of the wilfully narrow, the wrong-headed and the naive, but their criticism was tempered by the still acute polemical abilities of the radical nationalists. As the exchange between Heseltine and Phillips shows the charge of betraying the Australian past still had considerable force in the early i $960 s$. In this atmosphere of growing doubts about the viability of the 'Australian legend' and amidst calls for more sophisticated theoretical approaches to history there appeared Geoffrey Serle's From Deserts The Prophets Come: The Creative Spirit in Australia. ${ }^{23}$ Serle's book was partly a 'Summary presentation' of existing studies of 'high culture', but the author also claimed originality for his 'rudimentary attempt at a theory of cultural growth'. ${ }^{24}$ What was Serle's theory and how original was it?

The essential features of Serle's theory are conveyed in three explanatory chapters, 'Transplantation', 'The Growth of Culture in Colonies' and 'Literature and the National Problem'. While Serle provides much new documentation in each of these chapters, there seems to be little evidence of a new theory of cultural growth. Indeed, the author largely endorses the now familiar stages of cultural growth which proceed from colonial dependence to national assertiveness, finally to arrive after some vicissitudes at the 'relative abundance' and 'maturity' of the years since 1950. This is largely a story of progress, pervaded by the view that nations like individuals inherit stages of development which take them from 


\section{Dream and Disillusion}

childhood dependence on their parents, through a spotty, awkward and rebellious adolescence to mature adulthood. The Palmers had conceptualised the emergence of an Australian literature in roughly these terms from around World War I. Nettie Palmer's 'The Beginnings of Australian Literature', which appeared in Hassell's Australian Miscellany for 1921-2, and her subsequent booklet first published in 1923, both expound views on the dynamics of cultural growth in terms similar to Serle's. ${ }^{25}$ The Palmers expanded their views in a chapter titled 'On Australian Culture' which appeared in Australia, a symposium edited by Hartley Grattan. ${ }^{26}$ Among other subjects, they examined literature, art, architecture and music. In short, their emphasis, like Serle's, was largely on high culture. This is not to say that Serle merely repeats what others have said earlier, but it is fair to suggest that From Deserts The Prophets Come elaborates and in certain areas refines one of the mainstream interpretations of cultural growth in Australia. It does not present a new theory of cultural growth.

Serle's chapter on 'Literature and the National Problem', for example, is essentially a defence of those like the Palmers who have asserted the need for a national literature. They were concerned with local conditions for the Australian writer, but in Serle's view they were also 'staunch internationalists'. ${ }^{27}$ Over all, Serle agreed with those who argued that a concern for locality, far from being necessarily parochial, was a first step towards universality. At a less explicit level, Serle divided his cast into doers and spectators. He maintained that the people who had helped build the national culture, particularly the creative artists, deserved praise, not those who had preferred to remain aloof from the nation-building enterprise. He was particularly dismissive of 'those who continue to talk in terms of a cultural desert . . ' ${ }^{28}$ Russel Ward also considered that these individuals were contemptible: 'People who continue to talk of Australia as a cultural desert will, more embarrassingly than ever before, be exposing the condition of their own minds rather than saying anything meaningful about the country'. ${ }^{29}$ This emphasis on nationalism and its critics can give a false air of agreement among creative writers whose achievements and beliefs were widely divergent. Finally, Serle's nationalist convictions and abundant documentation help reduce his 'cast of thousands' to the same level of significance; a paradoxical outcome in a work that was 'frankly elitist'.

It is probably asking too much for a survey as extensive as 


\section{Conclusions}

Serle's to include more probing analyses of the intellectual makeup of his key figures, particularly as he had warned that the book did 'not pretend to be an intellectual history or to cover the ideas which have shaped Australia'.30 Yet is it possible to write a history of the creative spirit in Australia without discussing ideas? Serle seems to infer that there were fundamental laws of cultural growth which, if obeyed, would lead on to cultural maturity and if defied would bring failure. This notion recalls the previous arguments of Phillips who suggested that the individual had little choice but to work within the egalitarian and democratic assumptions of his community and Crawford, who wrote of the phases through which colonial societies passed.

Among historians, Michael Roe has stressed the importance of 'ideology' as a formative influence upon the Australian legend. In an exchange with Russel Ward, Roe argued that the 'men of letters' who were part of the 'cultural upsurge' of the r8gos and their successors, among them Vance Palmer and Russel Ward, 'felt with varying degrees of deliberation, the need to create an Australian type'. ${ }^{31}$ According to this view, writers were not merely retailing 'observed data' about Australian conditions, but were helping to create the 'facts' of Australian life. One of the points at issue between Roe and Ward was the degree of Australian indebtedness to European ideas. Roe maintained that the debt was large, whereas Ward preferred to stress the influence of the 'frontier' and 'the writer's own imaginative experience of Australian life'. In Ward's view the writer was largely a captive of his environment. His choices were limited in that he was virtually obliged to record the values of his community. Those who accepted these restraints were approved, while those who did not were hardly worth serious attention. They merely provided 'all unwittingly, a patently bogus latter-day substitute for the pedigreed "new-chum swells" and remittance men of the last century'. ${ }^{32}$ Statements of this kind place Ward's assertion that he was merely describing, not approving, 'the national self-image' in doubt. Ward, like Phillips, suggested that those who sought to detach themselves from national traditions were in danger of becoming anti-democratic or merely snobbish and futile. Roe valued detachment for it enabled him to pursue his line of inquiry without feeling bound to either flatter or condemn national sentiment. Yet he was conscious that the detached critic was in danger of having his approach dismissed as the 'bleatings of dry-as-dust academicism'. The risk increased when the historian 


\section{Dream and Disillusion}

questioned the distinctiveness of the 'Australian legend', doubted its factual base and suggested that many admired Australian qualities were 're-statements of the Enlightenment ideal of natural virtue, vulgarised to meet the case of mass democracy'. ${ }^{33}$ Roe returned to these and similar questions at more length in his article 'An Historical Survey of Australian Nationalism' published in $197 \mathbf{1}^{34} \mathrm{He}$ once again hoped that his analysis of nationalism would not be thought too 'academic', but added that the role of nationalism in Australian society was perhaps best described by a 'sceptic'. After suggesting several of the characteristics of nationalism, Roe re-affirmed that 'nationalism was an ideological reaction rather than an instinct or a natural law', although he could see no way of testing his 'hypothesis'.

It was not an aim of this book either to support or negate Roe's contentions about the importance of 'ideology' in explaining national identifications. Yet it became evident that the key figures of this study could not be understood in isolation from the cultural background of pre-war England, not to mention the influences of the I920s and I930s. Shaw, Wells, Chesterton and Orage pervaded their thinking, while the thought of Ibsen, Bergson and Nietzsche recurred in the journals they read and in their discussions of literature and the prospects of modern man. There were other vital influences. Louis Esson, for example, was a man clearly marked by successive waves of Irish influence. Oscar Wilde, George Bernard Shaw, J.M. Synge, W.B. Yeats and Padraic Colum all shaped Esson's imagination and affected his view of Australia. This is not to say that Esson made no attempt to relate his intellectual interests to Australian conditions, but that what he chose to stress in Australian life was profoundly influenced by the emphasis of the Irish literary movement. The continuing relevance of the years prior to World War I is testified by Vance Palmer's ABC broadcasts in the I940s and I950s from which Shaw, Chesterton and Wells emerged as the major literary personalities of the twentieth century.

The strength and persistence of such influences need not diminish nationalist sentiment. Clearly, the Irish example could inspire emulation, but English influences could also be readily accepted, particularly where the thinkers concerned sought to clear away what they considered the debris of the past in order to build a finer society. Criticisms of the English temperament and social structure after the manner of Edward Carpenter and A.R. Orage strengthened 


\section{Conclusions}

the hand of those who wanted Australia to chart a more independent and original national course than the one adopted by the existing leaders of Australian society. Indeed, the strength of national sentiment among radical nationalists was intimately related to the strength or otherwise of radical dissent within English society.

It should also be noted that ideas which began as avante-garde statements of an emerging new consciousness sometimes assumed uglier forms in later years. Ideas of a guild socialist kind reappeared in fascist Italy, while statements about the importance of a cohesive community were readily turned to conservative ends. P.R. Stephensen's nationalism turned nastily anti-semitic in the late 1930 , while Bulletin nationalism had grown increasingly narrow and reactionary. ${ }^{35}$ The changing character of national aspirations over time, the often intricate derivative elements in nationalist thinking and the many variations upon national emotions in any one period all detract from attempts to explain the emergence of a 'national culture' in terms of a steady ascent from colonial backwardness to national maturity. One of the contentions of this book is that the years 1900-14 encouraged some expansive views of the Australian future which were largely disappointed. Speculations about a guild socialist society might be placed in this category. So might the hopes for a 'sentient community' in which the barriers between individuals would be removed and replaced by an almost telepathic communal awareness. These hopes were not realised. The morale of the people appeared to collapse. It appeared that the forward movement which Palmer and his friends had looked for had changed into suburban stagnation where 'standardized minds in correctly-dressed bodies' were the rule. ${ }^{36}$ It was clear that by 1942 Louis Esson, for example, was virtually beyond optimism. Along with the apparent collapse of radical initiatives within Australian society, there was concern at developments in the wider world, particularly with the rise of fascism. In such a world there appeared to be scant hope for the fresh new democracy which civilised democrats throughout the Western world might learn to admire rather than patronise or dismiss. 


\section{Appendix \\ Pot-Boiling and Literature}

The question of economic reward is one which recurs in accounts of the writer's lot in Australia. A common view is that conditions were so poor that imaginative writing of any quality was hardly to be expected, although it is rare to find this opinion supported by convincing evidence either about Australian conditions or how they compare with those of other countries. The following observations will certainly not settle these issues, but they throw some light on the Palmers' circumstances and may provide leads for more systematic inquiries.

Mention was made in Chapter 3 of Vance Palmer's pot-boiling activities in the years I9IO-I7. There can be little doubt that Palmer studied the literary market with some care in these years. On his return to Australia in IgI 5 he wrote an article to the Bulletin on the state of the fiction market in England and America. ${ }^{1}$ Palmer told of how he had written stories at a guinea a thousand words around basic plots supplied by his agent. He had also written stories around pictures sent to him by magazine editors. In all, Palmer estimated that he had contributed to over a hundred papers and magazines since I905, but added that he had never been paid more than $f_{2} 20$ for these efforts. He had also published several serials. However, Palmer felt that the war had made the task of the writer more difficult in London, but he hoped that a more explicit concern for Australian themes would stimulate the local market, an argument which needs to be taken into account in explanations of Palmer's literary nationalism.

The pressure to write pot-boiling material which would maintain a steady basic income was relieved from March 1918 to November I919, when Palmer served as a private in the A.I.F. For at least some of this period Nettie Palmer took private tutoring, for in a letter to Esmonde Higgins early in 1919, she gave her weekly timetable which included seven French lessons and three small lecture groups in English literature. ${ }^{2}$

On his discharge from the army Palmer was once again faced with the need to earn a regular income from his writing. In 1920 he published The Shanty Keeper's Daughter. in the paperback series of A.C. Rowlandson's Sydney Bookstall Company, which probably earned him about $f 50^{3}$ From November IgI9 to October 1920 Palmer's weekly articles to the Advocate earned him two guineas an article. At the same time he was probably still circulating short stories to American magazines and was contributing to the Bulletin 


\section{Dream and Disillusion}

locally. From the middle of 1920 until the middle of 1923 Palmer contributed regular articles to Aussie: The Cheerful Monthly, and as Nettie Palmer commented in a letter to Esmonde Higgins in October I92 I, Vance was then writing many of the editorials. ${ }^{4}$ On 28 August 1920 Pals appeared and required short stories from Australian writers. Palmer's first contribution in October 1920 was titled 'The End of the Feud' and was given a station setting, structured around a father-son relationship. He had a further four short stories published in $192 \mathrm{I}$, three of them under the pseudonym Rann Daly. In 1922, he contributed five short stories and an eight part serial titled 'The Outlaws of Maroona'. Again he used the pseudonym Rann Daly and the station setting dominated. In the same year Palmer published The Boss of Killara as a Sydney Bookstall Company paperback. However, it took a constant effort to earn a living as Nettie Palmer pointed out to Esmonde Higgins in November I 921 :

Vance got a cheque of $£_{3.2 .6}$ yesterday for: - a Red Page article (3/4 column): Plain English article, same: piece of verse: and two pars. It simply doesn't bear thinking about. We just scrape along, but can't stretch fees like that. ${ }^{5}$

Earlier in the letter she had pointed out that conditions for the freelance writer had worsened since the war, for more and more newspaper and journal work was being done by permanent staff. At this time Louis Esson, who was always a reluctant pot-boiler and journalist, wrote of his success with an American editor who fancied him as 'a Chow writer' with a 'future'. It need hardly be said that writing of this type could prove to be quite revealing.

The question of earnings is clarified by the cash accounts given in the Palmer diaries from $1923 .^{6}$ In that year the Palmers earned $£ 278$. 7s. Id. from their journalism. Some idea of what this meant in I923 can be gained by comparing the total with salaries in the Commonwealth Public Service in the same period. On Io September 1923 the arbitrator's determination set the Public Service Basic Wage at $£$ r 93 per annum with child endowment of 5 s. a week for each dependent child under fourteen years. For an adult in his first year of service and with a wife and two dependent children the salary became $£ 224$ per annum. It was pointed out in the report that the actual salary was distinct from the minimum allowable and that:

A Clerk in the Commonwealth Service engaged on the lowest grade of clerical work, married, and maintaining three [two] children, will at 26 years of age be receiving $£ 276$ with $f 39$ $\left[\AA^{26}\right]$ child endowment, a wage of slightly over [under] $f^{6}$ a week.?

The bracketed comments describe conditions relevant to Palmer's situation with two dependent children. The public service had attendant benefits such as paid holidays and long service increments. 


\section{Appendix}

The clerk described could expect to earn $£ 276$ per annum and was twelve years younger than Palmer, who in 1923 was 38 . Considering his age and his experience Palmer's income was low in 1923 and had the further disadvantage of being irregular and uncertain. ${ }^{8}$

After an improvement in the financial year 1924/25 the Palmer income remained low for the next two years and then improved markedly from the financial year $1927 / 28$. The table allows a brief comparison with figures from public service salaries. ${ }^{9}$

\begin{tabular}{lcc}
\hline $\begin{array}{l}\text { Financial year } \\
\text { ending 30 June }\end{array}$ & $\begin{array}{c}\text { Average salary of adult } \\
\text { male in Commonwealth } \\
\text { Public Service including } \\
\text { child endowment }\end{array}$ & $\begin{array}{c}\text { Income of Vance } \\
\text { and Nettie Palmer } \\
\text { including child } \\
\text { endowment }\end{array}$ \\
\hline $1924 / 25$ & $\mathcal{E}$ & $\mathcal{E}$ \\
$1925 / 26$ & 312 & 380 \\
$1926 / 27$ & 315 & 267 \\
$1927 / 28$ & 315 & 285 \\
$1928 / 29$ & 321 & 510 \\
$1929 / 30$ & 330 & 532 \\
\hline
\end{tabular}

\begin{tabular}{cc}
$\begin{array}{c}\text { Nettie Palmer's } \\
\text { per cent of the income } \\
\text { for the period } \\
19^{24} / 25^{-1} 9^{2} 9 / 3^{\circ}\end{array}$ & $\begin{array}{c}\text { Nettie Palmer's earnings } \\
\text { not including } \\
\text { child endowment }\end{array}$ \\
\hline $8.8^{*}$ & $£$ \\
44.4 & 37 \\
26.0 & 107 \\
41.7 & 74 \\
49.6 & 202 \\
31.5 & 251 \\
\hline
\end{tabular}

In the low years $1925 / 26$ and $1926 / 27$ there was only one cheque for a sum over $£^{20}\left(£_{2} \mathrm{I}\right)$. The bulk of income in the two years came from a large number of contributions to magazines and papers which made a small return. In the year $1924 / 25$ Palmer had two serials running, one in the Argus and one in the Mirror, which brought him $£_{31}$ and $£_{55}$ respectively. There was also an entry from Angus and Robertson for $£ 4^{\circ}$ as payment for Cronulla, published in $1924^{10}$ The trend towards larger cheques was continued from 1927/28 to $1929 / 3^{\circ}$. In these years Nettie earned $f_{202}, 25 \mathrm{I}$ and $f_{286}$ respectively, much of it in literary journalism to the Brisbane

*Only articles attributed to Nettie in the cash account have been included in her total. As the cash account for I923 attributed very few articles to her, the figure for $1924 / 25$ is probably low. Articles were attributed more precisely from 1926 and are taken as accurate. 


\section{Dream and Disillusion}

Courier, the Tasmanian Mail, All About Books, the Australian Fournal and the Bulletin. This took some of the pressure off Vance, who was able to concentrate more on his novels, The Man Hamilton, Men are Human and The Passage. Men are Human won the third prize in the Bulletin novel competition for 1929 and The Passage won the first prize in the same competition for 1930.

The Bulletin prizes amounted to $\$ 400$ and did a lot to improve the Palmer income in the financial year $1929 / 30$ and helped also to secure Palmer's reputation as a serious novelist. Judging from the figures it would seem that Vance Palmer could build his reputation in Australia and live by his writing. However, he may have doubted the wisdom of staying in Australia in the early r 920 s when his income was low. Indeed, in a letter to Esmonde Higgins in 1923 Nettie Palmer suggested that she and Vance might be living in England by early 1924. ${ }^{11}$ They stayed in Australia, but still considered that conditions for writers were bad. In June 1924 Nettie Palmer noted in her diary: 'Constant note ... that more and more doors are being closed against the freelance. Edward Dyson feels the pinch now, after forty years'.12 The Palmers were also fecling the pinch, and in September 1925 Nettie wrote in the diary: 'V. [Vance] doing more journalism than enough these times. ${ }^{13}$ Reference to the cash account for the period shows that in the four months from September to December 1925 the Palmers had thirty-five articles published at an average of $\delta 3$ an article. It was a large output for a low return. At the same time the Palmers grew exasperated at the number of short stories the Bulletin returned unpublished. The first noted was in August 1925 and was followed by another reject in January 1926 . On 21 January there was another diary entry noting that a Red Page article had been returned. On I 5 February a short story was returned and Vance Palmer wrote to S.H. Prior asking if he had been excluded from the Bulletin. A further Red Page article was rejected in May 1928 and the diary comment on the Bulletin read simply: 'Hopeless!'14 To the Palmers, troubles with the Bulletin seemed symptomatic of the difficulties facing the freelance journalist in Australia in the mid-1920s.

The writer intent on earning a living from his writing had to accept that much of his time would be spent on pot-boiling and journalistic work which detracted from his more serious efforts as a writer. Vance Palmer and Louis Esson both tried to live by their writing, yet both men relied heavily on the support of their extremely capable wives. Nettie's contribution to the Palmer income was vital, particularly in the I920s, while Hilda Esson's income as a doctor was crucial to the financial stability of the Esson household. The vulnerability of their income from writing made Palmer and Esson anxious to improve conditions for the writer and on occasions it made them exasperated at the difficulty of organising writers and discouraged at the prospects of a national literature. Indeed, Palmer and Esson were more troubled by the status of the writer in Australia than men like Frank Wilmot and Frederick Macartney 


\section{Appendix}

who, although serious about literature, did not live by their writings. ${ }^{15}$

In the 1930 s the Palmers' income appears to have become more secure. Vance and Nettie Palmer were both well known as capable literary journalists and editors appear to have been willing to publish their work. From the late 193 os wireless broadcasts along with the $A B C$ Weekly articles provided a regular source of income, although there can be little doubt that work of this kind was often tiring and unrewarding. In addition to Palmer's war-time employment with the publication section of the Industrial Welfare Division of the Department of Labour and National Service from February I 942 to June 1944, there were occasional Commonwealth Literary Fund lectures, articles and stories and royalties from Palmer's novels. Without precise sales figures or knowledge of contracts the last item is difficult to calculate, but school editions of The Passage and The Rainbow-Bird and Other Stories boosted Palmer's sales considerably, although many of these sales would have been made after Palmer's death. There were several editions of The Passage before 1959 for which no figures appear to be available, but Gheshires report that from August 1959 to September 1974 almost 53,00o copies had been sold, while the school edition of The RainbowBird and Other Stories published by Angus and Robertson had sold almost 21 , 000 copies by the middle of $1972 .{ }^{16}$ Sales figures for other Palmer titles published by Angus and Robertson are as follows:

The Swayne Family

Seedtime

6509

The Big Fellow $376 \mathrm{I}$

Cyclone 1826

Hail Tomorrow 2500

Let the Birds Fly $77^{\circ}$

Golconda 2050

Hurricane 3492

Legend for Sanderson 2023

National Portraits 1987

Cronulla

The Rainbow-Bird \& Other Stories

IOIO

The Rainbow-Bird $\mathscr{E}$ Other Stories (School Ed.) 20650

Further sale figures for National Portraits and figures for The Legend of the Nineties are cited in the introduction. 


\section{Notes}

\section{Introduction}

${ }^{1}$ Vance Palmer, Louis Esson and The Australian Theatre (Melbourne, I 948 ), p. I.

2 Ibid. For further comment on writers' organisations in Melbourne see the author's Ph.D. thesis 'Writer and Community: Vance Palmer, Louis Esson, Frank Wilmot and Frederick Sinclaire, 1905-1930', Australian National University, October 1972.

${ }^{3}$ Ibid., pp. 195-200.

${ }^{4}$ The club is discussed briefly by Geoffrey Serle in an unpublished memoir of his father, Percival Serle.

${ }^{5}$ For an account of the $\mathrm{Y}$ Club see Constance Larmour, 'The "Y Club" and the One Big Union', Labour History, November 1970.

${ }^{6}$ R.E.N. Twopeny, Town Life in Australia (Sydney, 1973), p. 3. First edition, London I883. For an account of Twopeny, see Graeme Davison, 'R.E.N. Twopeny and Town Life in Australia', Historical Studies, October 1974.

'See Michael Cannon, Land Boom and Bust (Melbourne, 1972).

${ }^{8}$ See James Grant and Geoffrey Serle, The Melbourne Scene 18031956 (Melbourne, i 957), pp. I95-208.

- 'Melbourne', Trident, Vol. 2, No. 8, December 1908.

${ }^{10}$ Esson made the remark in 1924. It is quoted again in Ghap. 8 below.

${ }^{11}$ Geoffrey Serle, The Rush to Be Rich: A History of the Colony of Victoria 1883-1889 (Melbourne, 1971), pp. 158-9.

${ }^{12} \mathrm{H}$. McKay to Leon Brodzky, Io July 1905. Spencer Brodney Papers, State Library of Victoria, MS. 6067.

${ }^{13}$ I4 April 1910.

14 Vance Palmer to Nettie Higgins, 1912, Palmer Papers, MS. I 74 , Series 1.

${ }^{15}$ Reprinted in The Collected Poems of Bernard O'Dowd (Melbourne, I94I). Introduced by Walter Murdoch. See also Victor Kennedy and Nettie Palmer, Bernard O'Dowd (Melbourne, 1954), pp. I-3, and passim).

${ }^{16}$ Orage quoted in Tom Gibbins, Rooms in the Darwin Hotel: Studies in English Literary Criticism and Ideas 1880-1920 (Perth, 1973), p. 125. For the comment on Bergson see John Passmore, The Perfectibility of Man (London, 1972), p. 243.

${ }^{17}$ Edward Carpenter, England's Ideal and other Papers on Social Subjects (London, 1887), p. 44 .

18 Passmore, The Perfectibility of Man, p. 26o.

${ }^{19}$ K.S. Inglis, 'The Anzac Tradition', Meanjin Quarterly, No. I, 1965.

${ }^{20}$ Vance Palmer, ABC broadcast, 12 July 1943. 


\section{Notes Chapter 1}

${ }^{21}$ Information supplied by Patricia Kelly, senior archivist in the Australian Broadcasting Commission.

${ }^{22}$ Palmer's column began in December 1939 with the first numbers of the $A B C W e e k l y$. Circulation figures were supplied by Patricia Kelly.

${ }^{23}$ Figures supplied by Mrs J. Reid, Assistant Director, Melbourne University Press.

\section{Chapter I}

${ }^{1}$ H.M. Green, A History of Australian Literature: Pure and Applied (Sydney, 1961), 2 vols., p. 678 . The four other critical comments cited are: E. Morris Miller, Australian Literature: From its Beginnings to 1935 (Melbourne, 1940), 2 vols., p. 365; Eunice Hanger, 'Australian Drama' in Geoffrey Dutton (ed.), The Literature of Australia (Melbourne, ig64), p. 445; Keith Macartney, 'Louis Esson and Australian Drama', Meanjin Quarterly, No. 2, 1947; Leslie Rees, Towards an Australian Drama (Sydney, 1953), p. 80.

2 These points are developed below, but see in particular Esson's autobiographical note quoted in part on p. 15 .

${ }^{3}$ Esson's paraphrase in his article, 'Irish Memories and Australian 'Hopes', in Australian Quarterly, June I939.

${ }^{4}$ Palmer's memoir of Esson in Louis Esson, The Southern Cross and Other Plays. Introduced by Hilda Esson. (Melbourne, I946), p. 218.

${ }^{5}$ Details of the family background were provided by $\mathrm{Mr}$ Hugh Esson; Louis Esson's son, who was kind enough to grant me an interview on 30 July 1969 .

6 'Nationality in Art', Bulletin, I February 1923.

Article, Australian Quarterly, June 1939.

${ }^{8}$ L.B.E., 'A "Young Australia" Party', Bulletin, I4 January 1904, p. 9 .

${ }^{9}$ Spencer Brodney (Leon Brodzky) to author, I May 1972. In a most informative letter, $\mathrm{Mr}$ Brodney wrote of Louis Esson as he had known him before World War I. He referred to Esson's interest in Wilde's The Soul of Man Under Socialism.

10 Oscar Wilde, Plays Prose Writings and Potms (London, 1972), Everyman edition, p. 263 .

11 'A Pagan Hymn', Bulletin, 24 March I904, p. 3.

12 'Memories and Impressions' in 'Australian Art and Letters: The Struggle for Establishment', Vol. I (1908-27), E.J. Brady Papers, N.L.A., MS. 206, article 269/5I, p. 2 I5. For reminiscences of Sydney club life see G.A. Taylor, Those Were The Days (Sydney, 1918). For an account of Victor Daley see Phillip Carter; 'Victor Daley: Man and Poet', M.A. thesis, University of Adelaide, $197^{\circ}$.

13 'Critical Confessions' in 'Australian Art and Letters', article $269 / 5 \mathrm{I}$. The article was in long-hand and carried a note saying that it was not published. It was dated 1924.

14 'The Spirit of the Nineties', notes on an address read by proxy to the Henry Lawson Society of Sydney in 1938. 'Australian Art and Letters', Vol. I. 
${ }^{15}$ Robert D. FitzGerald, The Letters of Hugh McCrae (Sydney, 1970), p. 4.

${ }^{10}$ See J. Alex Allen, 'Bohemia in Melbourne: The Romance of Fasoli's', Argus, 6 August 1932, p. 6 for a brief history of Fasoli's. William Moore noted that Esson was the poet of the café in 'From My Scrap Book: The Waddy', New Triad, I September I927, p. I4. See also Allan Wynn, The Fortunes of Samuel Wynn: Winemaker, Humanist, Zionist (Melbourne, I968), p. 62 and E.J. Brady, 'Let Us Go To Fasoli's', Focus, Vol. I1, No. 6, 1947.

17 'Fasoli's', Bulletin, 4 October 1906.

18 'Socialists At Play', 23 October 1908.

${ }_{19} 3$ November 1904, A.G. Stephens Papers, ML Ab. 103.

${ }^{20}$ Brodney to Walker, I May i 972.

21 'Nationality in Art', Bulletin, I February 1923.

22 'What is an Australian?', Bulletin, 9 August I 906.

${ }^{23}$ Bulletin, 27 July 1905, p. 9. The monkey was an accepted description of the Japanese in the Bulletin of the period.

24 'The Bulletin's Lay Sermon - (suggested by the Religious Editor)', Bulletin, 23 November 1905.

${ }^{25}$ See R. Norris, 'The Emergent Commonwealth, IgoI-Igro' (Ph.D. thesis, Australian National University, I97o), pp. 253-6.

${ }^{26}$ Denton Prout, Henry Lawson: The Grey Dreamer (Adelaide, I963), p. 169 .

${ }_{27}$ Gadfly, 12 February 1907, p. 1013.

${ }^{28}$ Ibid., 20 March 1907, p. I094. Dorrington was born at Stratfordon-Avon, England, in 1871 . He came to Australia when he was sixteen and in 1907 he left Australia for England, where he spent most of his remaining years.

${ }^{29} 5$ April I 906, p. 3 .

30 'Reginald', 9 August Igo6, p. 44.

${ }^{31}$ See for example, 'The Younger Generation', Bulletin, I4 February 1907, p. 7.

32 Ibid., 17 January 1907 , p. 3.

${ }^{33}$ Ibid., 4 April 1907, p. 7.

${ }^{34}$ Esson to Leon Brodzky, I January I907, Spencer Brodney Papers, VSL.

${ }^{35}$ Heart of the Rose, Vol. I, No. I, 9 December i 907. My account of the article misrepresents its form. Esson wrote it as a conversation between three characters, the host, the mystic and the stranger. I have presented what I take to be Esson's case, rather than attribute statements to the characters named.

${ }^{36}$ I4 March 1909, Spencer Brodney Papers, MS. 6066.

${ }^{37}$ In 1910 Louis Esson made only five appearances in the Bulletin.

${ }^{38}$ Esson to Brodzky, I4 March 1909. Spencer Brodney Papers.

${ }^{39}$ H.C. McKay to Leon Brodzky, May 1905. Spencer Brodney Papers.

${ }^{40}$ McKay to Brodzky, 30 November Igog, Spencer Brodney Papers.

${ }^{41}$ Socialist, 24 February 191 I.

42 'Our Institutions: The Factory', Socialist, 7 April I9I I. 
43 'Eight Hours Day', ibid., 28 April 19 I I.

44 Ibid., I4 April I9I I.

${ }^{45}$ Bulletin, i 3 September Igo6, p. 9.

46 'Ganesha', 'Round the Corner', Lone Hand, I December 19o8, pp. 165-70. Ganesha was a pseudonym Esson sometimes used in the Bulletin and the Lone Hand. From 1906 he contributed poems to the Bulletin depicting the life of the slums. Two examples: a poem, 'Brogan's Lane', 20 September I9o6, p. 44, and a short story, 'Down the Red Rock Lane', ibid., I November r 9o6, p. 44. A note in the Melbourne University Magazine, September Igo8, p. 4I, noted that Esson had gained the title 'The Poet of the Slums' on the basis of his contributions to the Bulletin.

47 'Parliament', Socialist, 3I March IgI I.

48 'The Newspaper', ibid., 24 March IgI I.

49 'The Pub', ibid., 2 I April Igi I and 'The Church', ibid., 12 May IgI I.

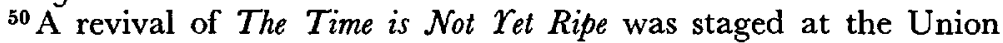
Theatre, University of Melbourne, from 20 to 24 June 1972.

51 The place of Marxists in the Victorian Socialist Party was the subject of discussion and dispute in the Socialist. Esson saw Marxists as outdated purveyors of a mechanistic theory of the universe. See his 'Socialism and Dogma', Socialist, 8 March 1912. In IgI3 a group of Marxists left the VSP. Esson was glad to see them go. See 'The Return of R.S. Ross: Louis Esson on the Party and the Movement', ibid., 2 May 19I3.

${ }^{52}$ The Time is Not Yet Ripe, p. I3.

${ }^{53}$ Ibid., p. 55 .

${ }^{54}$ Ibid., p. 56 .

55 Ibid., p. 64 .

${ }^{56}$ Ibid., p. 66 .

${ }^{57}$ Ibid., p. 69 .

${ }^{58}$ Argus, 24 July I 912 , p. 6.

59 I August I912;8 August I912. The play was favourably reviewed by Frederick Sinclaire in the Socialist, "The Time is Not Yet Ripe": A Dramatic Satire', I8 October 1912.

${ }^{60}$ McKay to Brodzky, 21 August 1908, Spencer Brodney Papers.

61 Esson to Stephens, I I December Igor, A.G. Stephens Papers, ML, Ae 20/I.

${ }^{62}$ Red Page, I I January 1912. The Lone Hand, I April 1912, praised Esson in similar terms to the Bulletin.

${ }_{63}$ Red Page, 28 November I9I2.

64 Esson to Stephens, 26 January 1912, A.G. Stephens Papers.

65 'The Repertory Theatre - Exit Shaw', Socialist, i I July I9I5.

${ }^{66}$ Interview between the author and Hugh Esson, 30 July 1969.

67 'The Australian Play', Bulletin, 5 November 1914.

Chapter 2

${ }^{1}$ A letter from the Official Secretary and Comptroller to the Governor General on Palmer dated 8 May $195^{2}$ stated that ' ... 


\section{Notes Chapter 2}

Her Majesty the Queen would be graciously pleased to approve of your being appointed an Officer of the Civil Division of the Most Excellent Order of the British Empire'. Palmer, never an enthusiast for the Empire, declined the offer. Palmer Papers, NLA. See C.B. Christesen, 'Comment', Meanjin Quarterly, No. 2, I959 for the reference to Melbourne University's intention to confer a 'high distinction' upon Palmer.

${ }^{2}$ Christesen, 'Comment'. Sir Keith Hancock was kind enough to show me a draft of his Boyer lectures.

${ }^{3}$ H.P. Heseltine, Vance Palmer (Brisbane, 1970), p. 2. Geoffrey Serle, Historical Studies, Vol. I5, No. 58, April 1972.

${ }^{4}$ Green, $A$ History of Australian Literature, p. I023. Geoffrey Serle, From Deserts the Prophets Come: The Creative Spirit in Australia 1788-1972 (Melbourne, I973), p. I19.

5 'The Man of Letters', Meanjin Quarterly, No. 2, I959, p. I93 and Phillips, 'The Short Stories', ibid., p. I 74.

${ }^{6}$ Heseltine, Vance Palmer, p. I2.

'Ibid., p. 202.

8 'The Man of Letters', p. 195.

9 Phillips, 'The Short Stories', p. I 77.

${ }^{10}$ This article is reprinted in John Barnes, The Writer in Australia: A Collection of Literary Documents 1856 to 1964 (Melbourne, 1969), pp. $16 \mathrm{I}-70$.

${ }^{11}$ Palmer to Nettie Higgins, n.d. [c. I91 2], Palmer Papers, MS. I I 74, folder 509 .

${ }^{12}$ Palmer's major autobiographical writings have been collected in Intimate Portraits and Other Pieces: Essays and Articles by Vance Palmer Selected with an Introduction by H.P. Heseltine (Melbourne, I969). Some of the articles appeared in Meanjin Quarterly, as follows: 'Uncle Halek', No. 3, I95 I, 'Fragment of Autobiography', No. I, 1958, 'Ancestors', No. 2, I 959 and 'London Days', No. 2, 1959. Drafts of 'My Father', 'Boarding School', and 'Doctor Wallace' are in the Palmer Papers.

${ }^{13}$ Heseltine, Intimate Portraits, p. 5 and p. 8.

14 'Boarding School'.

15 'Dr Wallace', p. 42.

16 'Dr Wallace', p. 45.

17 'Uncle Halek', p. 30.

18 Palmer to Nettie Higgins, October/November [1909], Palmer Papers, folder 515 and notes contained in Nettie Palmer's diary folder in 1939 , MS. I $174 / 9376$.

18 'Branscombe Sisters', in Vance Palmer, The Rainbow-Bird and Other Stories by Vance Palmer. Selected by Allan Edwards (Sydney, 1957).

${ }^{20} \mathrm{ABC}$ broadcast, 'Fifty Years of Changing Literature', January $195^{6}$.

${ }^{21}$ Nettie Palmer to Frederick Macartney, n.d. Held by Frederick Macartney. She wrote that Palmer went to London 'on the strength of some articles and stories he had accepted by Country Life and Nineteenth Century'. 
${ }^{22}$ Palmer, 'Steele Rudd', Overland, No. I5 (Winter 1959), p. 22.

${ }^{23}$ Palmer's account of his lodgings is in Intimate Portraits, p. 47;

Lindsay's in Comedy of Life: An Autobiography (Melbourne, 1967), p. 190.

24 Intimate Portraits, p. 47.

${ }^{25}$ Palmer to Nettie Higgins, March [19ro], Palmer Papers, folder 515 .

${ }^{26}$ Intimate Portraits, p. 48.

27 'The Literary Career', Bulletin, I 2 December 19 I 4.

${ }^{28}$ Comedy of Life, p. 193.

${ }^{29}$ Palmer to Nettie Higgins, 26 September 1909, Palmer Papers, Box 5 I5.

${ }^{30}$ See Lovat Dickson, H.G. Wells: His Turbulent Life and Times (London, 1972), Pelican ed., Chap. 9 and Hesketh Pearson, Bernard Shaw (London, I 964 ), p. 268. Wells gives an account of the Fabian conflict in. The New Machiavelli (London, IgI I). See Chap. r, Book three, 'The Riddle for the Statesman'.

${ }^{31}$ Stanley Cox to Palmer, Palmer Papers, no item number. In Intimate Portraits, p. 48, Palmer described Cox as the 'one close friend of those early days'. For Palmer on the Fabians see letter to Nettie Higgins, 26 September 1909, Palmer Papers, Box 515.

${ }^{32}$ Socialist, 26 February I 9o9, p. 3.

${ }^{33}$ Palmer Papers, no item number. See Chap. 5 below for an account of Sinclaire.

${ }^{34}$ G.E.W. Bean, On the Wool Track (Sydney, I945). Australian Pocket Library Edition, p. vii.

${ }^{35}$ Palmer to Nettie Higgins, 26 September 1909, Palmer Papers, folder $5 \mathrm{r} 5$.

${ }^{36}$ Palmer to Nettie Higgins [late 1909], ibid., no folder number.

${ }^{37}$ Palmer to Nettie Higgins, October [r9o9], ibid., folder $5^{1} 5$.

${ }^{38}$ Palmer to Nettie Higgins, n.d. [rgog], ibid.

${ }^{39}$ Intimate Portraits, p. 55.

${ }^{40}$ Palmer to Nettie Higgins, Palmer Papers, I5 October I9 Io, folder 508 .

${ }^{41}$ Nettie Higgins to Mrs John Higgins, ibid., folder 468 .

Chapter 3

${ }^{1}$ George Dangerfield, The Strange Death of Liberal England (London, r935). References are to the 1970 Paladin edition. This reference, p. I4.

${ }^{2}$ Walter Kendall, The Revolutionary Movement in Britain 1900-21: The Origins of British Communism (London, r969), p. 26.

${ }^{3}$ Dangerfield, Strange Death, quotations from pp. 199, 207, 208 respectively.

Ibid., pp. 249-50.

5 Ibid., p. 197.

${ }^{6}$ Palmer to Nettie Higgins, n.d. [c. April r912], folder containing letters with no date and no address. Palmer was a member of the ILP. 


\section{Notes Chapter 3}

${ }^{7}$ Palmer to Nettie Higgins, n.d. [April I9I2], folder 51 I.

${ }^{8}$ For an account of the New Age see Wallace Martin, The New Age Under Orage: Chapters in English Cultural History (New York, 1967) and Niles Carpenter, Guild Socialism: An Historical and Critical Analysis (New York, 1922). Although the New Age was peripheral to British life, even to socialist circles, guild socialism attracted some well known figures including Bertrand Russell, R.H. Tawney and G.D.H. Cole. For an account of the guild system see S.G. Hobson, National Guilds and the State (London, 1920). For a brief, recent account of guild socialism see S.T. Glass, The Responsible Society: The Ideas of Guild Socialism (London, Ig66).

9 For Palmer's account of Orage and the Nerw Age see 'London Days' in Intimate Portraits. 'Rough Faring' appeared 27 July I9I I. 'The Great War', 'A Mexican Patriot', 'A Holy Terror', 'Under Which King?', and 'A Lost Leader' appeared in the New Age on I4 September 191 I, 28 August I913, 23 October I9I3, i I December I9I 3 and 19 March 1914 respectively. These $\mathcal{N} e w ~ A g e$ stories along with others from the Manchester Guardian appeared as The World of Men in 1915.

${ }^{10}$ Palmer to Nettie Higgins [1913], Palmer Papers, folder 507.

${ }^{11}$ Orage, 'Notes of the Week', New Age, 28 May 1910.

12 Ibid.

${ }_{13}$ Ibid., 17 March I gro.

${ }_{14}$ Maisie Ward, Gilbert Keith Chesterton (London, 1944), p. 192.

${ }^{15}$ Hilaire Belloc, 'The Three Issues', Nere Age, 2 May I go8.

${ }^{16}$ Rerum Novarum: English Translation of Encyclical Letter to Pope Leo XIII on the Conditions of the Working Class (Melbourne, n.d.), Encyclical Letter, I 5 May I 891.

${ }^{17}$ See Intimate Portraits, $\mathrm{pp}$. 6o-I for Palmer's recollections of Titterton.

${ }^{18}$ New Age, r 8 July 1908.

${ }^{19}$ Palmer to Nettie Higgins, n.d. [1912], Palmer Papers, folder 509.

${ }^{20}$ Intimate Portraits, pp. 55-63.

${ }^{21}$ Palmer to Nettie Higgins, n.d. [I 1 12], Palmer Papers, folder 5 I I.

${ }^{22}$ All quotes from 'Patria Mia', New Age, 31 October 1912.

23 'Through Alien Eyes', ibid., 30 January I 9 I 3.

${ }^{24}$ It was on this trip that Palmer met Louis Esson. Palmer, Louis Esson, p. I.

${ }^{25}$ Palmer to Nettie Higgins, 18 December 1912, Palmer Papers.

${ }^{26}$ The articles appeared on 3,10 and 17 January I 9 I 3 .

27 Socialist, 17 January 1913.

${ }^{28}$ Ibid.

${ }^{29}$ Palmer to Nettie Higgins [c. June I 9 I I], Palmer Papers, folder 508.

${ }^{30}$ Some titles and some stories which appeared in the Sunday Chronicle are in the Palmer Papers, Series 9, item I, folder I.

${ }^{31}$ 'Melbourne Chatter', Bulletin, 28 September 1922. A marked copy of the Bulletin in the ANU archives shows Esson to be the author of this unsigned note. 


\section{Notes Chapter 3-4}

32 Palmer, Louis Esson, p. 10. Esson to Palmer, 28 June 1917.

${ }^{33}$ Palmer to Nettie Higgins, Palmer Papers, folder 562.

${ }^{34}$ Palmer 'An Open Letter to Stephen Walsh', New Age, i 8 April 1912.

${ }^{35}$ This and subsequent references to The World of Men (Melbourne, I 962 ).

${ }^{38}$ Ibid., p. 34 .

${ }^{37}$ Quoted in Maurice Friedman, To Deny Our Nothingness (London, $1967)$, p. 66.

${ }^{38}$ Palmer to Nettie Higgins, [c. end 1912], Palmer Papers, folder 507.

${ }^{39}$ Nettie Palmer to Esmonde Higgins, 20 May 1915, Esmonde Higgins Papers, ML, MSS. 704/8.

${ }^{40}$ All references to The Forerunners (London, 1915).

${ }^{41}$ In a letter cited in Chap. 2 from Stanley Cox to Palmer, 5 June 1908, Palmer Papers, Cox declared: 'Chesterton you rightly estimate: he is a "great man".' There is nothing to suggest that Palmer changed his view of Chesterton before 1914 .

\section{Chapter 4}

${ }^{1}$ See Chap. 2, p. 32.

${ }^{2}$ Chambers's Twentieth Century Dictionary of the English Language, London, I901.

${ }^{3}$ See Chap. I, p. 22.

${ }^{4}$ Frank Wilmot wrote much of his work under the pen name of 'Furnley Maurice' from 1905. His adoption of Furnley Maurice is discussed in Frederick T. Macartney, Furnley Maurice (Frank Wilmot) (Sydney, 1955), pp. 12-13. A bibliography of Frank Wilmot's work appears in Hugh Anderson (assisted by Barbara Ramsden), Frank Wilmot (Furnley Maurice): A Bibliography and a Criticism (Melbourne, I 955).

${ }^{5}$ This account of Henry Wilmot is based on Macartney, Furnley Maurice, pp. 4-5. His socialist affiliations were noted in an obituary in the Socialist, 9 March 1907.

${ }^{6}$ Macartney, Proof Against Failure (Melbourne, 1967), p. 33 and Macartney, Furnley Maurice, pp. 4-5.

7This description of the Book Arcade is based on Macartney, Furnley Maurice, pp. 6-7. See also Australian Dictionary of Biography, Vol. III, I85I-I890, for the entry on Edward William Cole by E. Cole Turnley.

${ }^{8}$ Anderson, Frank Wilmot, p. 10.

${ }^{9}$ O'Dowd to Nettie Higgins, 2 I January 1909, Palmer Papers, folder 445 .

${ }^{10}$ Macartney, Furnley Maurice, p. 12.

${ }^{11}$ Frank Wilmot, 'A Gigarette Dream', Microbe, No. 3, February I 902.

12 'Joseph Conrad Novelist', Book Lover, I November I 904 and part 2 of the same article, I December I904.

13 'Joseph Conrad', Lone Hand, i November 1912.

${ }^{14}$ Book Lover, I November I905. 


\section{Notes Chapter 4-5}

15 Thrush, March Igro.

16 'Myself and You', Trident, Vol. 2, No. Io, I February 1909.

17 'The Kept Poet', Bulletin, 7 February I907.

18 'The Merry Poet', Trident, Vol. 2, No. 3, I July 1908.

19 'To Bernard O'Dowd', Frank Wilmot Papers, ML, Vol. III, p. 19. MSS. $4 / \mathrm{I}$.

${ }^{20}$ Palmer in Louis Esson, The Southern Cross and Other Plays, p. 2 i 8.

21 'Perils and Dreams', Lilley's Magazine, Vol. I, No. 4, 7 September IgI I.

${ }^{22}$ See above Chap. 1 .

${ }^{23}$ Lilley's Magazine.

${ }^{24}$ Harold Monro to Frank Wilmot, 7 November I913, Frank Wilmot Papers, ML.

${ }^{25}$ Ross, The Georgian Revolt 1910-1922: Rise and Fall of a Poetical Ideal (Vermont, I 965), p. 59.

26 'Rupert Brooke', Book Lover, I May 1916.

${ }^{27}$ Triad. The article appeared in two parts on Io April 1917 and Io May I9I 7.

${ }^{28}$ Ibid., 1o May, p. 5 r.

${ }^{29}$ Ibid.

${ }^{30}$ Ibid.

31 Ibid.

32 Ibid.

33 Ibid.

\section{Chapter 5}

${ }^{1}$ For an account of the formation of the Victorian Socialist Party see Graeme Osborne, 'Tom Mann: His Australasian Experience 1902-1910', Ph.D. thesis, ANU, 1972, Chap. 4.

2 The quotations in this paragraph and this account of Victorian politics are drawn from L. Benham and J. Rickard, 'Masters and Servants: The Victorian Railway strike of 1903' in Strikes: Studies in Twentieth Century Australian Social History, edited by John Iremonger, John Merritt and Graeme Osborne, the special May I973 number of Labour History.

${ }^{3}$ J.A. La Nauze, Alfred Deakin: $A$ Biography (Melbourne, 1965) Vol. II, p. 364 .

4 Osborne, 'Tom Mann', p. I I 9.

5 Ibid., p. I 2 I for VSP membership. See pp. I 2 I-8 for an account of the activities of the party.

'Argus, I 8 and I9 June 19o6. Osborne, 'Tom Mann', pp. 132-3.

${ }^{7}$ Argus, 20 June 1906.

${ }^{8}$ Socialist, 29 May 1908.

${ }^{9}$ Details of schooling supplied by Mr W.H. Cooper, Headmaster, Auckland Grammar School to Professor Winston Rhodes, 2o March 1968. Held by Professor Rhodes in Christchurch as part of the Sinclaire Papers.

${ }^{10}$ Professor Winston Rhodes to author, interview, January 1970.

11 All information on Sinclaire at Oxford in the Reverend H.L. 


\section{Notes Chapter 5}

Short, principal of Manchester College, Oxford, to Professor Rhodes, 22 April 1968. Sinclaire Papers.

${ }_{12}$ Mrs Alan Mulgan to Professor Rhodes, i December I 964.

${ }^{13}$ All references to Poz are from excerpts in Short, Sinclaire Papers.

${ }^{14}$ Lecture delivered at the Bijou Theatre, 5 April igo8. Sinclaire's letter to Mann was referred to in the Socialist, I 7 April 1908.

${ }^{15}$ Socialist, I May I 908 carried a report of Sinclaire's lecture.

${ }^{16}$ Report on the formation of the Fabian Society, ibid., 23 October I908. For O'Dowd's involvement in the society and the club see Bernard O'Dowd to Nettie Higgins, 28 June 1908, Palmer Papers, MS. II 74, folder 445 and the same, 5 September 1908.

${ }^{17}$ The lecture was reported in the Socialist, 23 October 1908.

${ }^{18}$ Melbourne University Magazine, September 1908. Walter Murdoch was in the chair.

${ }^{19}$ Socialist, I December I908.

${ }^{20}$ Ibid., I 9 June 1908.

${ }^{21}$ Ibid., 26 February I 909 .

${ }^{22}$ Ibid., 2 r May Igog.

${ }^{23}$ Argus, 20 May 1908.

${ }^{24}$ The correspondence continued until 25 May.

${ }^{25}$ Argus, 22 May 1908.

${ }^{26}$ Deeds that Won the Empire, first published in 1897 and Fights for the Flag, first published in 1898, had sold nearly 350,000 copies by 1913; aggregate sales for all his books to that period were over 600,000 in England and Australia. Deeds that Won the Empire was serialised in the Argus during the 18gos. Fitchett's sales appeared in the Argus, 15 September 1927.

27 The Southern Cross, 3 I July igo8.

28 Ibid., Io March 19 Ir.

${ }^{29}$ Ibid., I9 March 1909.

${ }^{30}$ Ibid., 29 March I908.

${ }^{31}$ Preface to Deeds that Won the Empire.

32 The Southern Cross, 23 October 1908.

${ }^{33}$ Ibid., 12 November 1909.

${ }^{34}$ Ibid., 7 January 1910.

${ }^{35}$ I am grateful to Michael McKernan who allowed me to read his thesis, 'W.H. Judkins and the Social Reform Movement Melbourne 1906', Honours thesis, ANU, I97I. McKernan gives biographical details of Judkins and provides an account of his campaigns against moral laxity in Igo6.

${ }^{36}$ Gadfy, 5 December 1906.

37 'After Dark: Scenes in the Gardens: Mr Judkins' Experiences', Argus, 23 August 1910.

${ }^{38}$ Sinclaire's lecture was fully reported in the Argus, 'The Test of Figures: Rev. F. Sinclaire's Argument', 29 August I9 Io. See also Socialist report, 2 September 1910.

${ }^{39}$ Argus, 29 August 1910.

${ }^{40}$ The first address was on 2 I May I $9 \circ 9$ and the last on 25 June I 909. 


\section{Notes Chapter 5}

Quotations drawn from Argus, 4 June 1909. Fitchett criticised Sinclaire in The Southern Cross, 28 May 1909.

41 'On Dissolving Jesus Christ into "Aphorisms"', The Southern Cross, 5 August 19 Io.

42 The Argus correspondence ran from. II March IgIo to 16 March. ${ }^{43}$ Socialist, 25 February 1910.

4429 April 1910.

45 29 July 1910.

${ }^{46}$ Nettie Higgins to Mrs John Higgins, 28 September I9I I, Palmer Papers, MS. I I 74, folder $47 \mathrm{I}$.

47 Vance Palmer to Nettie Higgins, n.d., no address [London, I9I I ?], Palmer Papers, MS. I I 74, folder 512.

${ }^{48} \mathrm{O}^{\prime}$ Dowd to Nettie Higgins, 3 May 19ro, Palmer Papers, MS. I I 74 , folder 445 .

${ }^{49}$ For Macartney's religious upbringing see his autobiography, Proof Against Failure (Sydney, 1967), Chap. 4. The quotations in this paragraph are drawn from this chapter.

${ }^{50}$ Ibid., p. $3^{8 .}$

${ }^{51}$ Macartney, 'Socialism and Art: The View of the Artist', Socialist, 24 June 1910. Sinclaire was not named in this article but it seems clear that he was being referred to.

52 I asked Frederick Macartney and Guido Baracchi, both contemporaries of Sinclaire, about the circumstances of his resignation. Neither of them had definite knowledge, but suspected that Sinclaire had run into trouble with church authorities and presumed that this was related to his socialist activities. Interview with Baracchi, 30 July I969, and Macartney, October 1969. Just before his death Walter Murdoch, who had known Sinclaire in Melbourne, wrote of Sinclaire's resignation: 'I always understood, although he did not tell me, that he left the Unitarian Church because of the hypocracy [sic] of the head and started the Free Religious Fellowship on his own'. Walter Murdoch to Professor J.A. La Nauze [ 18 May 1970]. Copy held by author. ${ }^{53}$ Socialist, 7 October 1910.

54 Ibid., I 7 February I 9 I I.

${ }^{55}$ George Byrne, Fellowship, November 1916.

${ }^{56}$ C.R. Badger, The Reverend Charles Strong and the Australian Church (Melbourne, 1971).

${ }^{67}$ Ibid., p. 118.

${ }^{58}$ Sinclaire and Strong were the first two names, for example, on the 'Manifesto from Protestant Ministers'; a pamphlet which opposed conscription.

${ }^{59}$ It is not clear when Sinclaire became editor, but editorial articles of his appeared regularly from April I9I I. Marie Pitt was appointed co-editor. There was a note in the Socialist, 29 March 1912, confirming the appointments for the New Year.

60 'Socialist Theatre Party: John Gabriel Borkman', ibid., 23 June 1911 .

61'Repertory Theatre: Second Season', ibid., 8 September IgII. 
Sinclaire made further comments on the theatre, ibid., 9 June I9I I and 20 October I9II.

62 Sinclaire's address was noted in the Bulletin, 25 April rgI2, p. 22. 63 'A Doll's House: Ibsen in Melbourne', Socialist, ro May 1912.

${ }^{64}$ The Repertorian: The Australian Magazine of Art, Literature and Drama, September I916. There was one issue of this journal.

Ghapter 6

${ }^{1}$ Edward Carpenter, Civilisation: Its Cause and Cure (London, 1919), p. I I. [Ist ed. I889].

${ }^{2}$ Nettie Palmer to Esmonde Higgins, 15 November 1914, Esmonde Higgins Papers, Correspondence I9 10-1920, ML MSS. 740/8.

${ }^{3}$ Esmonde Higgins to Nettie Palmer, 25 October [1914], Palmer Papers, MS. I 174 , folder 514 .

${ }^{4}$ Esmonde Higgins to Nettie Palmer, 4 January 1915, Palmer Papers.

${ }^{5}$ Fellowship: Organ of the Melbourne Free Religious Fellowship, September 1914. From August 1917 the journal had the following subtitle: 'A monthly journal of undogmatic religion, and of social and literary criticism.'

${ }^{6}$ Ibid., October I9I4.

7 'Guild Socialism', ibid., September I915. This article was reprinted in the Socialist, 8 October 19I5. Sinclaire also wrote 'Political and Economic Power: Something of Labor's Objective and Guild Socialism', for Ross's Magazine, January 1916.

8 'National Guilds I - Introductory', June; 'Towards National Guilds - II', July; 'Towards National Guilds - III', August. Palmer preferred to use 'National Guilds' rather than 'Guild Socialism', perhaps in order to stress the national possibilities of socialism.

${ }^{9}$ Fellowship, June I 916.

${ }^{10}$ Ibid., March I9I6.

11 Ibid., March I9I 7 .

12 Ibid., March I 917.

13 Ibid., May 1916.

${ }^{14}$ An account of Melbourne University can be found in Geoffrey Blainey, A Centenary History of the University of Melbourne (Melbourne, 1957). See in particular Chap. 13, 'The March of Technology'. There are biographical entries for Spencer, Moore and Scott in Percival Serle, Dictionary of Australian Biography, Vol. II (Sydney, 1949).

15 'Towards a Living Culture', Fellowship, May 1916:

16 Ibid.

${ }^{17}$ For an account of Irvine's career see Bruce McFarlane, Professor Irvine's Economics in Australian Labour History (Canberra, 1966). For comments on Irvine's attitude to guild socialism see pp. 6-12.

${ }^{18}$ Irvine, The Place of the Social Sciences, p. 8.

19 Ibid. 
20 Ibid, p. 20.

21 Ibid., pp. I9-20.

22 Ibid., p. 20.

23 Ibid., p. 22.

24 Ibid.

${ }^{25}$ Fellowship, November 1916.

${ }^{26}$ Ernest Scott, Australia During the War (Sydney, 1936), p. 334: I am grateful to Dan Coward who allowed me to read a chapter of his Ph.D. thesis on the Universal Service League.

${ }^{27}$ I would like to thank Mr L.F. Fitzhardinge who allowed me to read a draft of the second volume of his biography of W.M. Hughes.

28 'The Two Australias', Fellowship, November I9I6.

${ }^{29}$ Ibid.

so 'Notes of the Month', ibid., February 1917.

${ }^{31}$ Ibid.

32 'The War of Ideals', Ross's Magazine, I April 1916.

${ }^{33}$ 'Notes of the Month', Fellowship, February I9I 7, June I9I9.

34 'Australian Nationalism and Some of Its Enemies', August I9r 7. 'Australian Nationalism', September Igr 7. Esmonde was under Vance's influence when he signed his articles with the pseudonym, 'Sliprail':

${ }^{35}$ For an account of the I.W.W. in Australia, see Ian Turner, Sydney's Burning (Sydney, I969).

${ }^{36}$ Sinclaire's article appeared in Fellowship, December 1916. Palmer's letter titled 'Unlawful Associations - Voices of the Jungle', appeared on 12 January 1917.

${ }^{37}$ Ian Turner, Industrial Labour and Politics (Canberra, 1965), pp. 142-5. For a detailed account of the strike see Dan Coward's article titled 'Crime and Punishment: The Great Strike in New South Wales, August to October 1917' in Strikes: Studies in Twentieth Century Australian Social History.

${ }^{38}$ Turner, Industrial Labour, p. I45.

${ }^{99}$ September 1917.

${ }^{40}$ Worker, 5 July 1917 to 27 December 1917 .

41 'The Need for Nationalism', ibid., 9 August 1917.

${ }^{42} \mathrm{~J} . W$. Gregory, Australia (Cambridge, 1916).

${ }_{43}^{43}$ 'Men or Rolling Stock?', Worker, 30 August 1917.

${ }^{44}$ Palmer to Nettie Palmer, Palmer Papers, MS. I 1 74/1/1 738.

45 'Notes of the Month', Fellowship, September 1917.

46 'Labour and Nationality', Worker, 31 January 1918.

47 'A National Danger', Australian Worker, 4 January 1917, p. I7, I J January 1917, p. I. I am grateful to Dan Coward and Ged Martin who allowed me to read a draft of their unpublished article, 'Australian Labor and Imperial Federation 1917'.

${ }^{48}$ Queensland Worker, 9 August 1917.

${ }^{49} M U M$, May r 9 I 7 .

${ }^{50}$ Tbid.

${ }^{51}$ The biographical information in this paragraph is based on 


\section{Notes Chapter 6}

recorded interviews with Guido Baracchi at his home in November 1969. There is a brief account of the Baracchi affair in Blainey, A Centenary History of the University of Melbourne, pp. I39-4I.

${ }^{52} M U M$, May 1917.

${ }^{53}$ Report, I4 July I 9 I 7 ; letters, I6 July.

${ }^{54} 17$ July.

${ }^{55} 23$ July.

${ }^{56} 6$ January.

${ }^{57}$ I4 June.

${ }^{58}$ Argus, 26 July 1917.

${ }^{50}$ Notice Paper of the Professorial Board Minutes, I I July 1917. Information supplied by Mr Frank Strahan, Melbourne University Archives.

${ }^{60}$ Professorial Board Minutes, I I July.

61 Ibid., 23 July.

${ }^{62}$ Menzies's letter had reached the galley-proof stage when it was withdrawn from the magazine. This letter is now in the Esmonde Higgins Papers. Menzies was a prominent undergraduate at Melbourne University at the time. In 1915 he was joint honorary secretary of the Law Students Association and on the board of management of $M U M$. In the following year he was editor of $M U M$, president of the SRC, and a lieutenant in the University Rifles. He made regular contributions to the magazine in the years when he was not obliged to do so as editor.

${ }^{63}$ W.P.E., 'The Victorian Labour College and What it Stands For: For the Workingclass and the Class Struggle', Socialist, ro May 1918. W.P.E., 'Labour Colleges', Fellowship, April 1918. A brief outline of the history of the college was given in The Aims and Early History of the Victorian Labor College: A Report of an address given by A.T. Brodney at the celebration of the fiftieth anniversary of the foundation of the Victorian Labor College... (Melbourne, 1967).

${ }^{64}$ Baracchi interview, pp. 2-3. Baracchi noted that Palmer prepared three leaflets: 'An Appeal to the Farmers', 'An Appeal to the Citizens' and a 'very striking' cartoon by Will Dyson from the London Daily Herald.

${ }^{65}$ Ibid., pp. 3-4.

${ }^{66}$ I 5 February 1918.

${ }^{67}$ Socialist, 22 February 1918, p. 2.

${ }^{68}$ Ibid.

${ }^{69}$ Ibid., 31 May 1918, p. 2.

${ }^{70}$ Ibid., 12 July 1918 and a further report 23 August 1918. In January I 918 Sinclaire was fined $f_{1}$ with $\ell_{2}$. I 2s. 6d. costs for printing an uncensored leaflet. Ibid., I8 January 1918.

${ }^{71}$ In $A$ Book of Australasian Verse, 2nd ed. (Melbourne, 1924), the poem appeared under the changed title, 'To God: From the Warring Nations'.

${ }^{72}$ This and all subsequent quotations from Poems, pp. $28-35$.

73 'Furnley Maurice Addresses a "Letter to God", Bulletin, 16 May 1917. 


\section{Notes Chapter 6-7}

74 'Two Voices', letter to Book Lover, July I9I7. The other voice was Walter Murdoch's. He wrote to Champion: 'I have not been so moved by anything that has been written since the war came, and I am very much your debtor for sending it to me.' Both letters are reprinted in Anderson, Frank Wilmot, pp. 38-41.

${ }^{75}$ 1o February 1921.

${ }^{76}$ Frank Wilmot to Percival Serle [n.d. 19r7]. Percival Serle Papers, VSL.

77 Worker (Sydney), 31 March I 9 I 0. Reprinted in Furnley Maurice, Eyes of Vigilance (Melbourne, 1920) and Poems.

\section{Chapter 7}

1 Diary, 7 January 1918, Palmer Papers, item 933.

2 Ibid., 10 May 1918.

${ }^{3}$ An outline of Palmer's army career was supplied in a letter to the author from the Central Army Records office, 6 October $197^{\circ}$. Palmer was one of the editors of Barambah Battler, a troopship magazine which also contains some of his poetry.

${ }^{4}$ Two articles of Palmer's on Ireland appeared in Fellowship; 'Dublin Days', March 1920 and 'Dublin Nights', April 1920.

${ }^{5}$ Palmer probably became known to the Advocate through Henry Minogue who was closely associated with Nettie's brother, Esmonde, on the controversial Melbourne University Magazine of 1917 . Later, the Palmers both contributed articles to Minogue's magazine, Australia. Minogue was literary editor of the Advocate when Palmer began his foreign affairs notes.

${ }^{6}$ Birth, March Igr8.

${ }^{7}$ Aussie, 16 August 1920.

8 'These are My People', in The Camp, 1920.

9 'Australia's Transformation', March I92I.

${ }^{10}$ L.F. Fitzhardinge, draft of Vol. II of the biography of W.M. Hughes.

11 Palmer to Nettie Palmer [mid] 19 1 7, Palmer Papers, folder 520.

12 'Anti-Conscription Documents, Brisbane, 1916', Document Section, Labour History, No. 26, May 1974.

${ }^{13}$ Hilda Esson to Nettie Palmer, I3 June 1918, Palmer Papers, folder 520 .

14 'Notes on the Month', June I921.

${ }^{15}$ Ibid., June 1922.

16 'Spiritualism and Immortality', ibid., November 1920.

17 'What a Japanese-American War Would Mean', Advocate, 7 October 1920.

18 'Eleven Years', Bulletin, 29 October 1930.

${ }^{19}$ The Camp, p. 25.

${ }^{20}$ Fellowship, August 1918.

${ }^{21}$ Book Lover, 2 I May $192 \mathrm{I}$.

${ }_{22}^{2} 24$ December I 92 I.

${ }^{23}$ Esson to Palmer, 22 January I92 I. Louis Esson, p. $3^{1}$.

${ }^{24}$ I 8 June 1921 . 
${ }^{25} 29$ August 1925 .

${ }^{26}$ I 1 April 1925.

273 January 1920.

${ }^{28} 22$ May 1926.

29 'Good-bye, Old Show. The Secretarial View of the Grisis in the V.S.P.', Socialist, 23 January 1920.

30 'Alive and Kicking: The Old Show', ibid., 6 February 1920.

${ }^{31}$ Nettie Palmer to Esmonde Higgins, 12 September 1920, Esmonde Higgins Papers, ML, MSS. 740/8.

${ }^{32}$ Ibid.

${ }^{33}$ Nettie Palmer to Esmonde Higgins, 25 September 1920, ibid., MSS. $740 / 8$.

${ }^{34}$ Nettie Palmer to Esmonde Higgins, 20 November 1919, ibid., MSS. $740 / 8$.

${ }^{35}$ Nettie Palmer to Esmonde Higgins, 5 September I92 I, ibid., MSS. $740 / 9$.

${ }^{36}$ Sinclaire to Esmonde Higgins, 7 June [1922], ibid., MSS. 740.

${ }^{37}$ Socialist, Io, I 7 August 1917.

${ }^{38} 20$ March Igrg.

${ }^{39}$ Fellowship, February 1920.

${ }^{40}$ Ibid.

${ }^{41}$ New Age, 28 September 1922. See Martin, The New Age under Orage, p. 289.

42 Ibid., p. 286.

\section{Ghapter 8}

1 Esson to Stewart Macky, 8 June 1921 in Palmer, Louis Esson, p. 40 .

${ }^{2}$ Hilda Esson to Vance Palmer, n.d. Palmer Papers.

${ }^{3}$ Vance Palmer, Louis Esson, p. 6.

4 'The Australian Play', Bulletin, 5 November 1914.

${ }^{5}$ Letter, 16 February 1917 in Palmer, Louis Esson, p. 6.

${ }^{6}$ Letter, 28 June i 917 , ibid., p. I I.

7 Ibid., p. 7. William Moore was born in Bendigo in I 868 and was educated at Scotch College, Melbourne. In Igog he organised the Australian Drama Nights in Melbourne. He served with the British army service corps during World War I and returned to Australia in the early I920s.

${ }^{8}$ Letter, November 1920 in Palmer, Louis Esson, p. 27. Esson wrote of his meeting with Yeats in 'W.B. Yeats on National Drama', Fellowship, August I921.

${ }^{9}$ Fellowship, August I $92 \mathrm{I}$.

${ }^{10}$ Esson, 'W.B. Yeats on National Drama'.

${ }^{11}$ Esson to Palmer, 22 January $192 \mathrm{I}$ in Palmer, Louis Esson, p. $3 \mathrm{I}$. ${ }^{12}$ See ibid., pp. 44-7.

${ }^{13}$ This list of performances was compiled from the theatre column of the Australasian for the relevant period.

14 Esson to Stewart Macky in Palmer, Louis Esson, p. 4 o.

15 Palmer, Louis Esson, p. 54. 


\section{Notes Chapter 8}

16 Ibid., p. 49.

17 Argus, 'Australian Drama: New Movement Shows Promise', I9 May I922, p. 7. Age, 'The Battler - An Australian Comedy', I9 May 1922, p. I I. For a savage review see Quinton Davis (C.R. Bradish), Triad, Io July 1922: 'One asks for something more than a parade of village simpletons defectively photographed'.

18 Australasian, 30 September 1922, p. 723.

${ }^{19}$ For criticisms of the film by Vance Palmer, Nettie Palmer and Frederick Sinclaire see 'Australia's Transformation', Fellowship, March 1921; 'Readers and Writers', Argus, 3 February I9 I7, and 'Australian Literature: The Outlook', in the Sinclaire Papers.

${ }^{20}$ Alan Marshall, This is the Grass (Melbourne, I962), pp. 153-4.

21 Ibid., p. I53.

22 Australasian, 29 July I922, p. 233 and 15 December I 923, p. 1292.

${ }^{23}$ Ibid., comments in the theatre notes in the period May to November 1922.

24 Ibid., 3 June 1922, p. 1011.

${ }^{25}$ Ibid., 23 December 1922, p. 1367 .

${ }^{26}$ Ibid., 9 September I922, p. $55^{1}$.

${ }^{27}$ Ibid., 24 March 1923, p. 593.

28 Ibid., 5 April 1924, p. 729.

${ }^{29}$ Ibid., 24 November 1923, p. 1120.

${ }^{30}$ Ibid., 17 March 1923, p. 54I.

31 Ibid., 23 June 1923, p. I 245.

32 Ibid., I 5 December 1923, p. I 292.

${ }^{33}$ Ibid., 4 August I923, p. 236.

34 Ibid., I I August 1923, p. 289.

${ }^{35}$ Ibid., 28 July 1923, p. I 85 .

${ }^{36}$ Ibid., 15 December I 923, p. 1292.

37 Ibid., 2 I October 1922, p. 888.

${ }^{38}$ Bulletin, 23 November I922, p. 37. This note is unsigned, but a marked copy of the Bulletin in the ANU archives shows that Esson was the author.

${ }^{39}$ Australasian, I 5 November I 924, p. 1165 .

40 Ibid.; I4 March 1925, p. 623.

41 Bulletin, 7 January 1926 , p. 13 .

42 March 1927, p. I 4 .

${ }^{43}$ Gayne Dexter, $S M H, 3$ September 1927, p. I I.

${ }^{44}$ Marshall, This is the Grass, p. 125.

45 'The Australian Film?', Current Affairs Bulletin, 18 December I967.

${ }^{46}$ Report of the Royal Commission on the Moving Picture Industry in Australia, I927. Summary of Recommendations, p. 29.

1729 July I 922 , p. 233.

4 Diary, 4 February 1924, Palmer Papers.

${ }^{49}$ Esson to Palmer, 20 January 1924. Palmer, Louis Esson, p. 55.

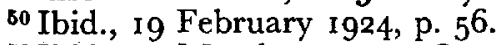

51 Ibid., I 5 March I 924 , p. 58.

52 Ibid., Esson to Palmer, I July 1924, p. 62. 


\section{Notes Chapter 9}

\section{Chapter 9}

1 Editorial, 'Back to Nature', I9 September I 925.

2 R.B. Plowman, Larapinta (Sydney, 1938).

3 Ibid., p. 10.

${ }^{4}$ Ibid.

${ }^{5}$ Ibid., p. 5 I.

${ }^{6}$ Ibid., p. 286.

${ }^{7}$ Bulletin, 8 February 1906.

${ }^{8}$ Hugh McKay to Leon Brodzky, 23 January 1906, Spencer Brodney Papers.

${ }^{9}$ Book Lover, I November 1905.

${ }^{10}$ Frederick Macartney, Poems (Melbourne, n.d.), p. 87. In the same volume see 'Commercium' and 'Metropolis'. O'Dowd's vicw of the city is evident in his poem 'The City' in The Poems of Bernard O'Dowd, pp. 53-6.

11 Bulletin, 6 March r929.

12 'Australia's Transformation', Fellowship, March 192 I.

13 'A Short-Cut for Critics', ibid., 9 July 1925.

14 'Literary America', Bulletin, I March 1923.

15 'Australian Literature - The Outlook', Age, 12 September 1927.

16 'Suburbia: Planned or Accidental?', Argus, 7 March 1931.

${ }^{17}$ These observations appeared in the preface to Speaking Personally (Sydney, 1932). This preface later became the first entry in Murdoch's Collected Essays of Walter Murdoch (Sydney, 1938).

18 'On Dull People', ibid., pp. 533-7.

19 'Australia's Transformation'.

${ }^{20}$ Louis Esson to Vance Palmer, I June 1921 in Louis Esson, p. 36.

${ }^{21}$ Reported in Nettie Palmer, Fourteen Years: Extracts from a Private Journal, 1925-1939 (Melbourne, I948), p. 54.

${ }^{22}$ Collected Essays of Walter Murdoch, p.627.

23 'Australian Literature: The Outlook'.

24 Ibid.

25 'Who Wants Freedom?', an address broadcast from Auckland by Professor Frederick Sinclaire on 14 September 1942.

${ }^{26}$ Frederick Sinclaire first lectured to tutorial classes arranged by the University of Melbourne Extension Board in 1924. He took English literature at Brunswick. In the following year Sinclaire's commitments were extended. He gave 16 lectures to the City Class and 24 to the Brunswick Class. In 1925 Sinclaire continued his City course, but he also lectured at Shepparton and Bendigo. In 1926 Sinclaire gave a series of lectures to his City course, at Brunswick and at Ballarat and Castlemaine. From I927 to May I 929 Sinclaire lectured and tutored mainly for the City course in English Literature. Information supplied by Cecily Close, Senior Assistant Archivist, Melbourne University Archives.

${ }^{27}$ W. J. Gardner; E.T: Beardsley and T.E. Carter, $A$ History of The University of Canterbury 1873-1973 (Christchurch, I973), p. 259.

${ }^{28}$ Ibid.

${ }^{29}$ For a recent account of Wilmot's later poetry see John Heuzen- 


\section{Notes Chapter 9}

roedler, 'Poet and Populace: Frank Wilmot's Poetry', Meanjin Quarterly, No. I, 1974.

30 'Tome', in Poems by Furnley Maurice (Melbourne, r944), p. 8r.

Firsit published in the Bulletin, 23 October 1929.

${ }^{31}$ Ibidl., p. 124. First published in the Melbourne University Magazine, Septtenber 1933 .

${ }^{32}$ Louis Esson to Vance Palmer, 23 November 1925 in Louis Esson, pp. 64-5.

${ }^{33}$ Louis Esson to Dymphna Cusack, 14 September 1942. Dymphna Cusiack Papers, NLA, MS. 462 I, Box I 3, Folder 4.

${ }^{34}$ Esson to Dymphna Cusack, July 1943, Cusack Papers, MS. $462 \mathrm{I} / \mathrm{I} / 5 \mathrm{I}$.

35 Ibid,

${ }^{36}$ I November I943, MS. 462 I/I/57.

${ }^{37}$ Interview, ibid.

${ }^{38}$ See Nettie Palmer and Len Fox, Australians in Spain: Our Pioneers Agains: Fascism (Sydncy, I948), pp. 32-4.

${ }^{39}$ Nettie Palmer to Esmonde Higgins, I3 November 19 14, Esmonde Higgins Papers.

40 'Rann Daly', 'A Letter from the Water Waggon', Aussie, I5 October I920.

${ }^{41}$ Palmer, The Camp, p. 10.

${ }^{42}$ I would like to thank Stephen Alomes who allowed me to read his draft chapter on censorship in the I93os.

${ }^{43}$ The extent of this literature can be gauged from three articles on war novels by Tristan Buesst in Stead's Review in 1930. Sce in particalar his 'Tumult of the War Books', I September 1930. See also Nettie Palmer, 'War Novels', All About Books, 20 August Ig29.

${ }^{44}$ Argus, 13 March 1930.

${ }^{45}$ Ibid., 25 April r 930.

46 Ibid., 22 May 1930.

${ }^{47}$ Diary, 3 July 1929.

${ }^{48}$ George Johnston, My Brother Fack (London, 1964), p. 162.

${ }^{49}$ See Argus, I7 April 1930 and 22 May 1930.

${ }^{50}$ Nettie pointed out that the Argus had ignored her letter in a diary entry on 2 I June 1930, the day the Age published the letter.

${ }^{51}$ An overview of the censorship can be gained from the Mitchell Library Newspaper Cuttings, Vol. 201, Book Censorship, $Q$. $323.445, \mathrm{~N}$.

52 Star, 5 February 1935.

${ }^{53}$ Ibid., 15 December 1934 .

${ }^{54}$ Herald, 26 December 1934 .

${ }^{55}$ Star, 27 February 1935 .

${ }^{56}$ Herald, 3 May 1935 .

${ }^{57}$ For Kisch's account of the visit see his Australian Landfall (Melbourne, I 969 ). The book was first published in 1937. The reissued edition contains a foreword by A.T. Yarwood which discusses the background and some of the consequences of Kisch's visit. 
${ }^{58}$ Ibid., xiv.

${ }^{59}$ Quoted in 'Kisch's Censored Speech: What They Prevented Kisch from Saying', compiled by A.F. Howells and including 'facts on the Kisch case'.

${ }^{60}$ The newspaper cuttings show that this speech was widely reported in the Australian press. The Mercury and the Queensland Telegraph both went on to comment upon the speech on 27 June 1935 .

${ }^{61}$ Nettie Palmer to Esmonde Higgins, 27 March I936, Esmonde Higgins Papers.

${ }^{62}$ George Orwell, My Couniry Right - or Left 1940-1943, Vol. 2 of The Collected Essays (London, I968), pp. 31-2.

${ }^{63}$ E.M. Andrews, Isolationism and Appeasement in Australia (Canberra, I970), p. 95 .

${ }^{64}$ Council for Civil Liberties, First Annual Report, May 1937.

${ }^{65}$ Nettie Palmer, 'The Spanish Struggle', in The Spanish People Present Their Case; pp. 3-6.

${ }^{66}$ Diary, 5 March 1937.

${ }^{67}$ Diary, ibid.

${ }^{68}$ Age, 3 March 1937.

${ }^{69}$ Ibid., 5 March 1937.

70 Ibid., 8 March I 937.

${ }^{71}$ Farrago, 5 April 1937.

72 Diary, 12 December 1937.

${ }^{73}$ Ibid., I 5 February I938.

74 Ibid., I 3 February I939.

75 Ibid., 5 June.

${ }^{76}$ See Andrews, Isolationism and Appeasement, p. 5 for the reference to Odets's play, pp. I58-9 for the Labor Daily incident and p. 160 for the response to Wells.

77 Ibid., p. 5 .

${ }^{78}$ Diary, 8 October 1937.

${ }^{79}$ Ibid., $3^{1}$ October $193^{8}$ and 21 May 1939.

${ }^{80}$ Undated memorandum for the Council for Civil Liberties, Brian Fitzpatrick Papers. I am indebted to Don Watson who drew my attention to this document.

${ }^{81}$ Frank Dalby Davison to Nettie Palmer, 29 November I 938. Palmer Papers, MS. I I 74/1/5463.

${ }^{82}$ Ibid., 5 July I937, MS. I I 74/1/5279.

${ }^{83}$ Hartley Grattan, 'Australia Awaits a Cue', Current History, December I937.

${ }^{84}$ Brian Penton, Advance Australia - Where? (Melbourne, I943), p. 2.

85 Ibid., p. I 2.

${ }^{86}$ Ibid., p. I4.

${ }^{87}$ Fourteen Years, pp. 40-I.

${ }^{88}$ Vance Palmer, 'Battle', Meanjin Quarterly, No. 8, 1942.

Chapter ro

'Jack Lindsay, 'The Novels', Meanjin Quarterly, No. 2, 1959. A.D. Hope, 'Homo Australiensis; Vance Palmer The Passage and 


\section{Notes Chapter 10}

Golconda' in Native Companions (Sydney, 1974) Heseltine, Vance Palmer.

${ }^{2}$ Vance Palmer, Let The Birds Fly (Sydney, I953). Vance Palmer, The Rainbow-Bird and Other Stories, selected by Allan Edwards, (Sydney, 1957).

3 'The Bridge' was published in Art and Letters: Hassell's Australian Miscellany 1921-2 (n.d., Melbourne).

${ }^{4}$ March r9io, Palmer Papers, folder 515.

${ }^{5}$ This and subsequent references are to the Australian Pocket Books edition of The Man Hamilton (Adelaide, 1960), p. 46.

${ }^{6}$ Ibid., p. 47.

${ }^{7}$ Nettie Palmer, diary, I6 October I928, Palmer Papers.

${ }^{8}$ Ibid., 2 March 1926.

${ }^{9}$ The Man Hamilton, p. 154.

${ }^{10}$ Men are Human (London, 1928), p. 33.

11 The Man Hamilton, p. 24.

12 'Novels for Men', Bulletin, Ig April 1923.

${ }^{13}$ Palmer to Nettie Higgins, 26 September igog, Palmer Papers, folder 5 I 5 .

${ }^{14}$ Palmer to Nettie Higgins [ 19 ro], ibid.

${ }^{15}$ Nettie Palmer to Vance Palmer [1930], ibid., Series $1 / 35^{60}$.

16 The Man Hamilton, p. 120.

${ }_{17}$ Palmer, Louis Esson, p. 8I.

${ }^{18}$ See John Tregenza, Australian Little Magazines 1923-1954 (Adelaide, I964).

${ }^{19}$ Nettie Palmer, Fourteen Years.

${ }^{20}$ Carpenter, England's Ideal, p. 75.

${ }^{21}$ Nettie Palmer, diary, 12 January 1928, Palmer Papers.

${ }^{22}$ Fourteen Years, p. 18.

${ }^{23}$ Palmer, 'Provincialism in Literature', Bulletin, 7 January 1926.

24 Vance Palmer, The Passage (London, 1930). All references to the I 964 Cheshires reprint. P. I 32.

${ }^{25}$ Ibid., p. 260.

${ }^{26}$ Ibid., p. 257.

${ }^{27}$ Ibid., p. 268.

28 Ibid., p. 270.

${ }^{29}$ Heseltine, Vance Palmer, pp. 79-92.

${ }^{30}$ The Passage, p. 4.

${ }^{31}$ Diary, 7 September 1928.

${ }^{32}$ The Passage, p. 21.

${ }^{33}$ Ibid., p. 9 .

${ }^{34}$ Palmer to Frank Wilmot, Frank Wilmot Papers, ML, MSS. 4/7, item 2 I.

35 'Vance Palmer on the Australian Novel', All About Books, I9 April 1930.

${ }^{36}$ Fourteen Years, p. 131.

${ }^{37}$ Diary, 17 February 1934.

${ }^{38}$ Nettie Palmer to Esmonde Higgins, n.d. [1934?], Esmonde Higgins Papers. 
${ }^{39}$ Vance Palmer, The Swayne Family (Sydney, I934), p. 21.

${ }^{40}$ Nettie Palmer to Esmonde Higgins, n.d. [1934?], Esmonde Higgins Papers.

41 The Swayne Family, p. 12 I.

${ }^{42}$ Ibid., p. 169 .

${ }^{43}$ Ibid., p. I 72.

${ }^{44}$ Ibid., p. I 73 .

45 Ibid.

46 Ibid., p. 246.

47 Vance Palmer, Legend for Sanderson (Sydney, 1937), p. 35.

${ }^{48}$ Ibid., p. 69 .

${ }^{49}$ Vance Palmer, Golconda (Sydney, I947). All references are to the 1972 University of Queensland Press edition. P. Io6.

${ }^{50}$ Ibid., p. 152.

${ }^{51}$ Vance Palmer, The Big Fellow (Sydney, 1959). This reference 1973 UQP edition, p. 26 r.

${ }^{52}$ S. Encel, Equality and Authority (Melbourne, 1970), p. 215.

${ }^{53}$ Vance Palmer, The Legend of the Nineties (Melbourne, 1954);

Vance Palmer, 'The Legend of the Nineties', ABC broadcast, I 2 September 1954.

${ }^{54}$ Vance Palmer, 'Current Books Worth Reading', ABG broadcast, I 5 June 1952.

${ }^{55}$ The Legend of the Nineties, p. 169 .

${ }^{56}$ Ibid., p. 172.

${ }^{57}$ Ibid., p. I 30.

\section{Chapter $\mathbf{I}$}

1 The Southern Cross, 20 April I917, p. 242.

${ }^{2}$ Guido Baracchi described this party to me. Interview.

${ }^{3}$ There is a further discussion of attempts to organise writers in Chapter 6 of the author's Ph.D. thesis.

4 'The R.A.A.', Red Page, 17 May I9I 7.

${ }^{5}$ See Appendix for further comment on this subject.

${ }^{6}$ Nettie Palmer to Aileen Palmer, 24 October 1943. MS. Palmer Papers $1174 / 1 / 6430$.

${ }^{7}$ R.M. Crawford, An Australian Perspective (Melbourne, I960), p. 1.

${ }^{8}$ Ibid., p. 52.

9 Ibid., p. 76.

${ }^{10}$ H.P. Heseltine, 'The Literary Heritage', Meanjin Quarterly, No. I, I 962 .

${ }^{11}$ Arthur Phillips, 'The Literary Heritage Reassessed', ibid., No. 2., I 962 .

12 Peter Coleman, 'Introduction: The New Australia', in Australian Civilization (Melbourne, 1962).

${ }^{13}$ R.W. Connell, 'Images of Australia', Quadrant, March-April 1968. Reprinted in Don Edgar (ed.), Social Change in Australia (Melbourne, 1974).

${ }^{14}$ Letter to the author from Sir Keith Hancock, n.d. See also W.K. Hancock, Country and Calling (London, 1954), and Professor Sir 


\section{Notes Chapter 11}

Keith Hancock, Today, Yesterday and Tomorrow: The 1973 Boyer Lectures (Sydney, 1973), pp. 9-10.

${ }^{15}$ See James Burkhart Gilbert, Writers and Partisans: $A$ History of Literary Radicalism in America (New York, I968).

${ }^{18}$ Warren Osmond, The Dilemma of an Australian Sociology (Arena Publications, Melbourne 1972).

${ }^{17}$ Ibid., p. 6.

${ }^{18}$ Ibid., p. 52.

${ }^{19}$ Warren Osmond, 'Australianism and the Sociologist', paper delivered to the SAANZ conference, 19 August 1972.

${ }^{20}$ Humphrey McQueen, A New Britannia (Melbourne, 1970). See also McQueen's 'Australo-Marximus; On some Reactions to A New Britannia', Politics, May I972. McQueen lists his reviewers at the end of this article.

${ }^{21}$ See McQueen, 'The Suckling Society' in Mayer and Nelson, Third Reader, 1973 .

${ }^{22}$ Ibid.

${ }^{23}$ Serle, From Deserts.

${ }^{24}$ Ibid., XI. For the author's review of Serle's book see Labour History, May 1974, pp. 94-5.

${ }^{25}$ Edward Vidler (ed.), Art and Letters, pp. 8-io. Nettie Palmer, Modern Australian Literature, 1900-1923 (Melbourne, 1924).

${ }^{26}$ G. Hartley Grattan (ed.), Australia (Galifornia, 1947).

${ }^{27}$ From Deserts, p. 143.

${ }^{28}$ Ibid., p. 232.

${ }^{29}$ See reviews of Serle by Russel Ward, Hartley Grattan and Bernard Smith in Historical Studies, October 1974. See also H.P. Heseltine 'A Relaxed, Upright Stance: Serle's Cultural History', Meanjin Quarterly, No. 2, 1973.

${ }^{30}$ From Deserts, XI.

${ }^{31}$ Michael Roe and Russel Ward, "The Australian Legend: An Exchange', Meanjin Quarterly, No. 3, 1962.

${ }^{32}$ Russel Ward, The Australian Legend (Melbourne, 1958). This reference to the first paperback edition, 1966, p. $25^{8}$.

${ }^{33}$ Meanjin Quarterly, No. 3, 1962.

${ }^{34}$ The Victorian Historical Magazine, November 197 I.

${ }^{35}$ For an account of Stephensen see Bruce Muirdon, The Puzzled Patriots (Melbourne, 1968).

${ }^{36}$ Palmer, The Swayne Family, p. 162.

\section{Appendix}

1 'The Distant Fiction Market that looks Blue', Bulletin, I I December IgI5.

${ }^{2}$ Nettie Palmer to Esmonde Higgins, 26 March I919, Esmonde Higgins Papers, ML, 740/8. On I6 April 1918 Nettie Palmer wrote to Frank Wilmot: 'I'm muggy after an hour with a dull pupil and another period doing correspondence coaching. I seem to spend my time hunting for pupils then wishing they were fewer'. Frank Wilmot Papers. 


\section{Notes Appendix}

${ }^{3}$ There is a receipt for this sum in the Palmer diaries for 1923 for another Bookstall novel, probably The Enchanted Island. Folder 935.

4 Nettie Palmer to Esmonde Higgins, 23 October 1921, Esmonde Higgins Papers, ML, 74o/9.

${ }^{5}$ I 4 November 1921 , Esmonde Higgins Papers, ML, 740/9. It was in this letter that Nettie noted that Vance received two guineas a week for his Advocate articles.

- Although there are subsequent cash entries in the diary that refer to the sale of various items, there is no guarantee that the account kept was a full one.

'First Report of the Commonwealth Public Service by the Board of Commissioners 1923-4, I4 October 1924, p. 48.

${ }^{8}$ These calculations are based on the Palmers' earnings from journalism in the calendar year and have been compared with figures on public service salaries calculated on the financial year I July 1922 to 30 June I 923 . The Palmers may have had other sources of income not listed in the diary, tutoring for example, but there is no evidence of additional income.

${ }^{\ominus}$ Figures based on subsequent reports of the Commonwealth Public Service Board. Calculations for the Palmers' income are based on the cash accounts entered in the diaries 1923-30. There are no cash accounts before I 923 .

${ }^{10}$ On 18 December 1924 Nettie Palmer wrote to Esmonde Higgins: 'He [Vance] has some new books out [The Enchanted Island, The Outpost and Cronulla] ... but his bankbook doesn't seem to notice. The most successfully selling one, Cronulla, was published by Angus and Robertson last month on their opinion that it was a good, quiet book that wouldn't sell. So Vance accepted a small sum down and no royalties, and the bandy book has had a second edition - five thousand - in less than three weeks'. Esmonde Higgins Papers, 740/9.

${ }^{11}{ }_{25}$ September 1923, Esmonde Higgins Papers, ML, MS. 740/9. 1227 June 1924 , folder 934 .

${ }^{13}$ I I September 1925, folder 935. Several months before this diary entry Nettie had written to R.H. Long: 'Writing a book means stopping journalism, that is, stopping income for the time! And what you get from a book, even a very successful book, may be negligible.' 24 May 1925, R.H. Long Papers, VSL, MS. 7033, Box $383 / 4 \mathrm{C}$.

${ }^{14}$ Diary, 31 August 1925, folder 935: 'Bulletin oddly returned a story, "The Frost" which ought to have pleased them on their sophisticated side at least, but they are chaos.' I 6 January 1925 , a further short story returned and Nettie wrote: 'The standard becomes more and more impossible'. 2I January 1925: 'Bulletin returned R.P. [Red Page] article of Vance's. Can this be a Plot ...'. I5 February $1926:$ ' $\mathrm{V}$ had another story returned without comment from the Bulletin, making the third M.S. recently.'

${ }^{15}$ Apparently in response to a criticism of Nettie Palmer's about the terms and distribution of works published by Sydney J. Endacott, 


\section{Notes Appendix}

a publishing business in which Frank Wilmot had a part interest, Macartney wrote: 'the publication by Endacott of my one or two little books of verse [Commercium, 1917, In War Time, IgI8, Poems, I920, Something for Tokens, 1922] was as good an arrangement as I could expect. I wanted to publish them as cheaply as possible, and I never expected any sort of wide interest in them, so they were printed and more or less casually distributed among booksellers who in any circumstances would have regarded them as so much lumber. I felt, in short, that the Endacott concern was merely a means of formally getting my verses out and that I could not rightly claim a greater interest'. Macartney to Nettie Palmer, I2 January 1928, Palmer Papers.

16 Publication figures were provided by the publishers at the author's request. 


\section{Selected Bibliography}

\section{A. Manuscripts}

E.J. Rupert Atkinson Papers. National Library of Australia.

E.J. Brady Papers. The National Library of Australia and the Mitchell Library both have collections of Brady's personal papers: chiefly of interest for material on writers' organisations and some letters from Palmer.

Spencer Brodney Papers. State Library of Victoria. Contains several letters from Esson to Brodney in the period 1904-12. In this period Brodney appears as Leon Brodzky.

Brian Fitzpatrick Papers. Consulted while in the possession of Dorothy Fitzpatrick. The papers have now been forwarded to the National Library of Australia. They were used mainly in connection with the Council for Civil Liberties.

Esmonde Higgins Papers. Mitchell Library. Particularly valuable for a number of letters from Nettie Palmer to Esmonde Higgins in the years $1910-30$.

Norman Lilley Papers. Mitchell Library. Correspondence with Wilmot, Macartney and others.

Richard Hooppell Long Papers. State Library of Victoria.

Dr George Mackaness Papers. National Library of Australia. Correspondence with a range of Australian writers including the Palmers, Louis Esson and Frank Wilmot.

Frederick Macartney Papers. Held privately by Mr Macartney in Melbourne. Correspondence with Melbourne literary figures, notably Wilmot and the Palmers.

Bernard O'Dowd Papers. State Library of Victoria.

The Palmer Papers. National Library of Australia. The chief manuscript source for this study. Letters from Vance Palmer to Nettie Higgins, 1909-14 (thereafter Nettie Palmer) until I959. General correspondence, particularly from Louis Esson, Frank Wilmot, Katharine Susannah Prichard and Frederick Macartney and Palmer diaries.

Marie Pitt Papers. National Library of Australia.

Percival Serle Papers. State Library of Victoria.

Frederick Sinclaire Papers. Held by Professor Winston Rhodes, Christchurch, New Zealand. The papers contain some biographi- 


\section{Selected Bibliography}

cal information on Sinclaire and transcripts of some of his articles. A.G. Stephens Papers. Mitchell Library.

Frank Wilmot Papers. Mitchell Library. Contains correspondence with Melbourne literary figures.

\section{B. Newspapers, periodicals and magazines}

I. NEWSPAPERS AND PERIODICALS (The following have been read primarily for articles by key figures in the book and for background opinion on cultural life in Australia.)

Advacate (Melbourne), 1917, I919-20.

Age (Melbourne), I9I9-23.

Argus (Melbourne), I909-I I, I9I5-18, 1925-28.

Australasian (Melbourne), 1917, 1927.

Bulletin (Sydney), rgoo-33.

Brisbane Courier (Brisbane), I927-29.

Labor Call (Melbourne), igi8-ig.

Illustrated Tasmanian Mail (Tasmania), 1927-28.

New Age (London), 1907-22.

New Statesman (London), 1913-15.

One Big Union Herald (Melbourne), ז919.

Socialist (Melbourne), 1907-21.

Worker (Sydney), I9I 7 .

Worker (Queensland), I916-18.

2. MAGAZINES (Dates refer only to the years for which the journal has been consulted.)

$A B C$ Weekly (Sydney), 1939-45.

All About Books (Melbourne), 1928-33.

Aussie (Sydney), 1920-25.

Australia (Melbourne), I917-18.

Barambah Battler (Troopship magazine), 1918-19.

Barambah Souvenir (Troopship magazine), 1918-19.

Birth (Melbourne), 191 7-22.

Book Lover (Melbourne), I904-2 I.

Dawn (Melbourne), I9I 7 .

Fellowship (Melbourne), 1914-22.

Gadfy (Adelaide), rgo6-9.

Heart of the Rose (Melbourne), I907-8.

Lilley's Magazine (Sydney), Igr I.

Lone Hand (Sydney), Igo7-21.

Melbourne University Magazine (Melbourne), I907-rg. 


\section{Selected Bibliography}

Microbie (Melbourne), rgor-2.

Native Companion (Melbourne), igo7.

Pals (Mebourne), i 920-7.

Patchwork (Melbourne), 1900-5.

Poz (Minchester College), 1905-7. [Extracts were consulted in the Sinclaire Papers.]

Repertorion (Melbourne), I916.

Ross's Monthly (Melbourne), 1915-20.

Stead's Riview (Melbourne), I925-31.

Spinner (Melbourne), 1924-27.

The London Aphrodite (London), I928-29.

Tocsin (Melbourne), I897-1900.

Triad (Sydney), I9I5-27.

Trident (Melbourne), 1907-9.

Verse (Melbourne), 1929-33.

Vision (Sydney), I923-24.

Waddy (Melbourne), no date [1905].

\section{General Bibliography}

(Authors are in alphabetical order: entries under each author in chronological order. Articles and other writings referred to in the text by Esson, the Palmers, Sinclaire and Wilmot are listed chronologically under the author.)

Anderson, Hugh (assisted by Barbara Ramsden), Frank Wilmot (Furnley Maurice): A Bibliography and a Criticism. London, 1955.

Australia. Royal Commission on the Moving Picture Industry. Report, 1927. C.P.P., I926/28, IV, pp. I 37 I-401.

-Public Service Board. First Report of the Commonwealth Public Service by the Board of Commissioners, 1923 -4.

Badger, C.R., The Reverend Charles Strong and the Australian Church. Melbourne, I97I.

Barnes, John, The Writer in Australia: A Collection of Literary Documents 1856 to 1964. Melbourne, 1969.

- Joseph Furphy. Melbourne, 1963.

-'Vance Palmer: Man of Letters', Meanjin Quarterly, No. 2, I959. This issue of Meanjin Quarterly was published as a tribute to the Palmers and contains articles and appreciations relevant to their life and work.

-'A.G. Stephens and the Critic's Tasks', Meanjin Quarterly, No. 4, I 968.

Bean, C.E.W., On the Wool Track. Sydney, 1910. 


\section{Selected Bibliography}

-The Story of Anzac: From the Outbreak of War to the End of the First Phase of the Gallipoli Campaign, May 4, 1915. Sydney, 1938.

Belloc, Hilaire, 'The Three Issues' (articles on the 'Servile State'), New Age, 2 May 1908.

Boyd, Martin, 'Dubious Cartography', Meanjin Quarterly, No. I, I 964 .

Brady, E.J., 'Labor in Relation to Culture', Worker (Sydney), 6 May 1905.

Brodney, A.T., The Aims and Early History of the Victorian Labour College (pamphlet). Melbourne, 1967.

Buckley, Vincent, 'The Image of Man in Australian Poetry', in Vincent Buckley (ed.), Essays in Poetry Mainly Australian. Melbourne, 1957 .

Carpenter, Edward, England's Ideal and Other Papers on Social Subjects. London, 1887 .

-Civilisation: Its Cause and Its Cure. London, 1919.

Carpenter, Niles, Guild Socialism: An Historical and Critical Analysis. New York, 1922.

Childe, V.G., How Labour Governs. London, 1923.

Christesen, C.B., On Native Grounds: Australian Writing from Meanjin Quarterly. Sydney, 1967 .

Clark, C.M.H., Select Documents in Australian History, 1788-1850. Sydney, $195^{\circ}$.

-'Melbourne: An Intellectual Tradition', Melbourne Historical Journal, No. 2, 1962 .

- 'Re-writing Australian History', in T.A.G. Hungerford (ed.), Australian Signpost. Melbourne, 1956.

Connell, R.W., 'Images of Australia', Quadrant, No. 2, 1968.

Covell, Roger, Australia's Music: Themes of a New Society. Melbourne, I967.

Crawford, R.M., An Australian Perspective. Melbourne, 1960.

- The Australian National Character: Myth and Reality', Fournal of World History, Vol. I I, 1955.

Groll, R.H., I Recall: Collections and Recollections. Melbourne, I939.

Davidson, Alastair, The Communist Party of Australia. Stanford, 1969.

Davies, A.F., 'Private Politics. A Study of Five Political Outlooks'. Melbourne, I962 (multilith).

Davison, F.D., 'Vance Palmer', Overland, No. 5, 1955.

Docker, John, Australian Cultural Elites: Intellectual Traditions in Sydney and Melbourne. Sydney, 1974.

Duncan, H.D., Language and Literature in Society. Chicago, 1953. 


\section{Selected Bibliography}

Dutton, Geoffrey (ed.), The Literature of Australia. Melbourne, r 964 . W.P.E. [Earsman], 'The Victorian Labour Gollege and What it Stands For: For the Workingclass and the Class Struggle', Socialist, Io May Igr 8.

-'Labour Colleges', Fellowship, April 1918.

Eldershaw, M. Barnard, Essays in Australian Fiction. Melbourne, $193^{8}$.

-'Vance Palmer and the Short Story', Sydney Mail, 13 January 1932.

Elliott, Brian, Singing to the Cattle and other Australian Essays. Melbourne, 1947 .

-Marcus Clarke. Oxford, $195^{8}$.

Esson, Louis.

\section{BOOKs}

-Bells and Bees; Verses. Melbourne, rgro.

- Three Short Plays. Melbourne, Igr I.

-The Time is Not Yet Ripe: A Comedy in Four Acts. Melbourne, I 912.

-Red Gums and Other Verses. Melbourne, IgI2.

-Dead Timber and Other Plays. London, 1920.

-The Southern Cross and Other Plays. Melbourne, 1946.

ARTICLES etc.

-'A "Young Australia" Party', Bulletin, I4 January 1904.

- 'A Pagan Hymn' (poem), ibid., 24 March Ig04.

-'The Pension' (poem), Waddy, Vol. I, No. I, n.d. [1905].

- 'The Willow Tree' (poem), ibid.

-'A Ballade of Bohemia (Old Style)' (poem), Bulletin, 5 April rgo6.

-'What is an Australian?', ibid., 9 August 1906.

- 'Reginald' (short story), ibid.

— "L.E." Expounds', ibid., 13 September 1906.

-'Brogan's Lane' (poem), ibid., 20 September 1906.

-'Fasoli's' (poem), ibid., 4 October Igo6.

—'Down the Red Rock Lane' (short story), ibid., I November 1906.

- 'The Immigrant' (poem), ibid., I 7 January 1907.

- 'The Younger Generation' (poem), ibid., i4 February 1907.

- North and South' (poem), ibid., 4 April 1907.

- 'Terra Australis: Fragments of a Conversation', Heart of the Rose, 9 December 1907.

- [Ganesha], 'Round the Corner', Lone Hand, i December 1908.

-'The Curse of Compromise', Socialist, I 5 July 1910.

--'Bernard O'Dowd', ibid., 24 February I9I I.

-'The Right to Strike', ibid., I 7 March IgI I. 


\section{Selected Bibliography}

-'The Inky Way', Bulletin, 23 March Igi I.

-'The Newspaper', Socialist, 24 March I9I I.

-'Parliament', ibid., 31 March I9I I.

- 'The Suburban Home', ibid., I4 April I9I r.

—'The Pub', ibid., 2 I April I9I I.

—'The Eight Hours Day', ibid., 28 April IgI1.

- 'The Church', ibid., 12 May r9I I.

- 'Melbourne Repertory Theatre', ibid., 22 December I 9 I I.

'Socialism and Dogma', ibid., 8 March IgI 2.

-'The Return of R.S. Ross', ibid., 2 May IgI3.

- 'Contemporary Poetry', Fellowship, April 1920.

- 'The Washington Square Players', ibid., July 1920.

- 'W.B. Yeats on National Drama', ibid., August I92 I.

- Nationality in Art', Bulletin, I February r923.

-'Katharine Susannah Prichard', ibid., 31 March 1927.

From 1924 to 1927 Esson contributed a regular column on the theatre in the New Triad.

Evatt, H.V., Australian Labour Leader. The Story of W.A. Holman and the Labour Movement, abridged edition. Sydney, I954.

Fitzhardinge, L.F., William Morris Hughes: A Political Biography, Vol. I. Sydney, I 964 .

Fitzpatrick, Brian, The British Empire in Australia. Melbourne, 1941.

-A Short History of the Australian Labor Movement. Melbourne, 1944. Glass, S.T., The Responsible Society: The Ideas of Guild Socialism. London, 1966.

Gollan, R:, Radical and Working Class Politics: A Study of Eastern Australia, 1850-1910. Melbourne, 1960.

Gordon, Richard (ed.), The Australian New Left: Critical Essays and Strategy. Melbourne, I970.

Graham, B.D., The Formation of the Australian Country Parties. Canberra, I 966.

Grant, James and Serle, Geoffrey, The Melbourne Scene 1803-1956, Melbourne, 1957.

Grattan, C. Hartley, Australian Literature (pamphlet). Washington, I929.

-Introducing Australia. New York, 1942.

-(ed.) Australia. California, I947.

Green, H.M., A History of Australian Literature, 2 vols. Sydney, $196 \mathbf{1}$. Greenwood, G. (ed.), Australia. A Social and Political History. Sydney, 1955.

Gregory, J.W., Australia. Cambridge, Igr6. 


\section{Selected Bibliography}

Hadgraft, G.H., 'The Fiction of Vance Palmer', Southerly, No. I, 1949 .

Hancock, W.K., Australia. London, 1930.

- Country and Calling. London, I954.

- Today, Testerday and Tomorrow: the 1973 Boyer Lectures. Sydney, 1973.

Heseltine, H.P., Vance Palmer, Brisbane, 1970.

-Intimate Portraits and Other Pieces: Essays and Articles by Vance Palmer Selected with an Introduction by H.P. Heseltine. Melbourne, I969.

- 'The Literary Heritage', Meanjin Quarterly, No. I, 1962.

Higgins, E.M., David Stewart and the W.E.A. Sydney, 957.

- 'Australian Nationalism and Some of its Enemies', Fellowship, August 1917.

-'Australian Nationalism', ibid., September 1917.

Higham, Charles and Wilding, Michael (eds.), Australians Abroad: An Anthology. Melbourne, 1967 .

Hobson, S.G., National Guilds and the State. London, 1920.

Holburn, Muir and Pizer, Marjorie (eds.), Creeve Roe: Poetry by Victor Daley. Sydney, 1947.

Hoggart, Richard, The Uses of Literacy. London, 1957.

-Speaking to Each Other, Vol. 2, London, 1970.

Hope, A.D., 'Vance Palmer Reconsidered', Southerly, No. I, I 955.

- 'The Prose of Nettie Palmer', Meanjin Quarterly, No. 2, 1959.

Inglis, K.S., 'The Anzac Tradition', Meanjin Quarterly, No. I, I 965 .

—'The Australians at Gallipoli - I', Historical Studies, No. 54, 1970.

-'The Australians at Gallipoli - II', ibid., No. 55, 1970.

Jebb, Richard, Studies in Colonial Nationalism. London, 1905.

Johnston, G., Annals of Australian Literature. Melbourne, 1970.

Jose, A.W., The Romantic Nineties. Sydney, 1938.

Lamour, Gonnie, "The "Y Glub" and the One Big Union', Labour History, November 1970.

La Nauze, J.A., Alfred Deakin: A Biography, 2 vols. Melbourne, 1965 .

-and Nurser, Elizabeth, Walter Murdoch and Alfred Deakin on Books and Men: Letters and Comments, 1900-1910, Melbourne, I974.

Lawson, Henry, The Prose Works of Henry Lawson, 2 vols. Sydney, 1935 .

-'Pursuing Literature', Bulletin, 2 I January I 899.

Lindsay, Jack, Life Rarely Tells: An Australian Boyhood. London, I $95^{8 .}$ 


\section{Selected Bibliography}

- The Roaring Twenties: Literary Life in Sydney N.S.W. in the Years 1921-1926. London, 1960.

- Fanfrolico and After. London, 1962.

- 'The Alienated Australian Intellectual', Meanjin Quarterly, No. I, 1963 .

—'The Novels' [of Vance Palmer], Meanjin Quarterly, No. 2, 1959. Lindsay, Lionel, Comedy of Life: An Autobiography. Melbourne, I967. Lindsay, Norman, Creative Effort: An Essay in Affirmation. London, 1924 .

Long, R.H., Verses. Adelaide, I9I 7.

Macartney, Frederick T., Proof Against Failure. Sydney, 1967.

-Furnley Maurice (Frank Wilmot). Sydney, 1955.

-Australian Literature; A Bibliography to 1938 by E. Morris Miller, M.A. Litt. D. Extended to 1950. Edited with an Historical Outline and Descriptive Commentaries by Frederick T. Macartney. Sydney, 1956.

-Australian Literary Essays. Melbourne, 1957.

-'Socialism and Art: The View of the Artist', Socialist, 24 June I9Io.

-'Joseph Furphy Again', Fellowship, January 1918.

Macartney, Keith, 'The Plays' [of Vance Palmer], Meanjin Quarterly, No. 2, 1959.

Marshall, Alan, This is the Grass. Melbourne, I962.

Martin, Wallace, The New Age under Orage: Chapters in English Cultural History. Manchester, 1967.

McBriar, A.M., Fabian Socialism and English Politics, 1884-1918. Cambridge, Ig66.

McKellar, J., 'Vance Palmer as a Novelist', Southerly, No. I, I954. McQueen, Humphrey, A New Britannia. Melbourne, 1972.

- Australian Gultural Elites', Arena, No. 36, 1974.

Miller, E. Morris, Australian Literature From its Beginnings to 1935: A Descriptive and Bibliographical Survey of Books by Australian Authors in Poetry, Drama, Fiction, Criticism and Anthology with Subsidiary Entries to 1938, 2 vols. Melbourne, I940.

Moore, T. Inglis, Social Patterns in Australian Literature. Sydney, 1971 .

Murray-Smith, Stephen, Henry Lawson. Melbourne, 1962.

Narasimhaiah, G.D. (ed.), An Introduction to Australian Literature. Brisbane, 1965 .

O'Dowd, Bernard, The Poems of Bernard O'Dowd. Melbourne, I94I.

-Poetry Militant: An Australian Plea for the Poetry of Purpose. Melbourne, rgog.

—'The Utility of the Political Machine', Socialist, 22 July 19 ı. 


\section{Selected Bibliography}

—'The Value of Literature to a Young Nation', Felloreship, August 1918.

Orage, A.R., 'Notes of the Week', New Age, I7 March I9ro. [The article examined the relationship between socialism and nationalism.]

Osmond, Warren, The Dilemma of an Australian Sociology. Melbourne, 1972.

Palmer, Nettie.

BOOKS

- The South Wind. London, 1914.

-Shadowy Paths. London, 19I5.

- Modern Australian Literature, 1900-1923. Melbourne, I924.

-Henry Bournes Higgins. Melbourne, 1931.

-Fourteen Tears: Extracts from a Private Fournal, 1925-1939. Melbourne, 1948.

-Henry Handel Richardson: A Study. Sydney, I950.

-[with Victor Kennedy], Bernard O'Dowd. Melbourne, 1954.

\section{ARTIGLES}

-'Poetry in Wartime', Argus, I I November I9 I6.

-_Readers and Writers', ibid., 3 February, 4 August I9I 7.

- 'Literature and Otherwise', Australia, 7 November 1917.

- 'A Poet's Verses', Socialist, I8 January I918.

- 'Henry Handel Richardson', Bulletin, 15 October 1925.

- 'Why Authors Leave Home', ibid., 5 August 1926.

- 'The Author and His Homeland', ibid., 4 November 1926.

-'The Showing Up of Walt Whitman', ibid., 25 November 1926.

- 'Three of Our Novelists', ibid., 26 June 1927.

-'Australian Authors' Week: A Chance for Revivals', Brisbane Courier, 9 July 1927.

- 'Australian Authors' Week September 12 to September 19', Illustrated Tasmanian Mail, 31 August 1927.

-'Shaw Neilson's Third Book', Bulletin, 22 December 1927.

-'A Year's Round', ibid., 29 December 1927.

- 'Thomas Hardy', ibid., 25 January 1928.

- 'D.H. Lawrence: One of Our Visitors', Brisbane Courier, ${ }_{4} 4$ April 1928.

-'The Poetry of W.B. Yeats', Illustrated Tasmanian Mail, 20 June I 928.

—'Martin Mills' Writing', Bulletin, ro September 1928. 


\section{Selected Bibliography}

-'Irish Plays: The Abbey Theatre', Brisbane Courier, 24 November I 928 .

-'From Outside' (on Hartley Grattan and Australian Literature), Illustrated Tasmanian Mail, 28 November 1928.

-'A Lawson Anthology', ibid,, I3 April 1929.

From 9 January 1943 to I I December I 943 , Nettie Palmer contributed a weekly book review to the $A B C$ Weekly.

Palmer, Vance,

\section{BOOKS}

-The Forerunners. London, 19 I 5.

- The World of Men. London, I9I5.

- The Camp. Melbourne, I920.

-The Shanty Keeper's Daughter. Sydney, 1920.

-The Boss of Killara. Sydney, 1922.

- The Enchanted Island (pseudonym, Rann Daly). London, 1923.

-The Outpost (Rann Daly). London, I924.

- The Black Horse and Other Plays. Melbourne, 1924.

-Cronulla: A Story of Station Life. Sydney, I924.

-The Man Hamilton. London, 1928.

- Men are Human. London, 1930.

-The Passage. London, 1930.

- Separate Lives. London, 193 I.

-Daybreak. London, 1932.

- The Swayne Family. Sydney, 1934.

- Sea and Spinifex. Sydney, I934.

-Legend for Sanderson. Sydney, 1937.

- National Portraits. Sydney, 1940.

-A.G. Stephens: His Life and Work. Melbourne, I941.

-Frank Wilmot (Furnley Maurice). Melbourne, 1942.

-Louis Esson and the Australian Theatre. Melbourne, 1943.

-Cyclone. Sydney, I948.

-Golconda, Sydney, 1948.

- The Legend of the Nineties. Melbourne, 1954.

$\rightarrow$ Seedtime, Sydney, 1957.

- The Big Fellow. Sydney, 1959. ARTIGLES etc.

- 'An Australian National Art', Steele Rudd's Magazine, January I905.

-'The Representative System', New Age, i6 February IgI I.

- An Open Letter to Stephen Walsh', ibid., I8 April I9I2.

-'The Coming Tyranny', Socialist. Three articles appearing on 3, Io and 17 January 1913 . 


\section{Selected Bibliography}

-'The Mexican Situation', New Statesman, 23 August 1913.

- 'The Mexican Impasse', ibid., I September Igi3.

—'Toward a Living Culture', Fellowship, May ig 6.

- National Guilds I - Introductory', ibid. First of three articles on this subject which appeared in June, July and August IgI6.

- 'Unlawful Associations-Voices of the Jungle', Socialist, I 2 January 19 I 7 .

-'Our National Ideals', Fellowship, February 19 I 7.

- 'Joseph Furphy's Poems', Socialist, g February 1917.

-'A Note on Joseph Furphy', Fellowship, March I9I 7.

-'A Duty on Imported Words', Bulletin, 28 June 1917.

-Preface to Such is Life. Melbourne, I9I 7.

Beginning in July 1917 Palmer contributed 14 articles to the Queensland Worker under the general heading, 'Towards Industrial Democracy', as follows:

—'Will Australia Lead the Way?', ibid., 5 July I9 7.

- 'Unionism for Farmers', ibid., I9 July 1917.

-'The Need for Nationalism', ibid., 9 August 1917.

—'The White Australia Policy', ibid., 16 August 1917.

-'Men or Rolling Stock?', ibid., 3o August 19 I 7.

- 'The Question of Railway Control', ibid., 16 September 19 I 7.

- 'The State and the Union', ibid., 20 September Igr 7.

- "Speed Up" and "Go Slow", ibid., 27 September 1917.

-'The Problem of the Farmer', ibid., 4 October 1917.

-.The Warfare Against Unionism', ibid., i I October 1917.

-'What Industries are Necessary?', ibid., 18 October 1917.

- 'The Status of the Union', ibid., 25 October 1917.

- 'Are We Lagging Behind?'; ibid., x November I9I 7.

- 'Towasds Industrial Democracy', ibid., 27 December 1917.

Also appearing in the Worker but not as part of the foregoing series were the following three articles:

- 'Labor and Nationality', ibid., 31 January 1918.

—'The Elight of the Peerage: Has it Touched Australia?', ibid., 21 February i9i 8.

- 'The Imperial Conference: What is Our Mandate?', ibid., 28 March I9I8.

-S.H.D. [Vance Palmer], 'Gurrent Comment', Fellowship, August I9I7.

- 'Taylo: and His Card System', ibid., September 19 I 7.

- Public Opinion', Australia, 7 November 1917.

-Note on Furphy (R.P.), Bulletin, 31 January I918. 
—'Cables', Australia, 7 March I9r8.

-'i914-1918' (poem), Birth, March I9I8.

From 15 November 1919 to 3 I October 1920 Palmer contributed a weekly foreign affairs article to the Advocate.

-'Dublin Days', Fellowship, March I920.

-'Dublin Nights', ibid., April 1920.

-'Europe' (poem), ibid., July r 920.

-'Australia's Transformation', ibid., March I92 I.

- 'The Spirit of Prose', ibid., May 192 I.

- 'Criticism as Craft', Ross's Magazine, 2 July $192 \mathrm{I}$.

-'Henry Lawson', Birth, September 1922.

- 'The Bridge' (short story), Art and Letters: Hassell's Australian Miscellany 1921-2.

Regular articles by Palmer appeared in the New Triad from 1924-7.

- 'The Writer and His Audience', Bulletin, 8 January 1925.

From December 1939 until 2 January 1943, Palmer published a weekly book review in the $A B C$ Weekly.

-'Frank Wilmot', Australian Quarterly, June 1942.

-'Uncle Halek', Meanjin Quarterly, No. 3, I951.

-'Ancestors', ibid., No. 2, 1959.

-'London Days', ibid., No. 2, 1959.

-'Steele Rudd', Overland, No. 15, 1959.

BROADCASTS etc. (The following is a list of Palmer's broadcasting commitments with the ABG from 1941.)

I94I Trochus Island

Tribute to Banjo Paterson

Current Books Worth Reading (book reviews) (24 scripts)

I942 Current Books (22 scripts)

Australian Ballad Poetry:

Beginnings

Banjo Paterson \& the Bush Ballad

Henry Lawson \& the Ballad of Ideas

This Changing Australia:

National Gulture \& the Outside World

Verse Session - Enid Derham \& James Devanny

Homage to Henry Lawson

It Takes Readers as Well as Writers to Make Literature (8 June 1942, 2BL, 8.00 p.m.), Vance and Nettie Palmer. This talk was the last of a series on Australian Literature. The previous speakers were Brian Penton, Jean Devanny, 


\section{Selected Bibliography}

Frank Dalby Davison, Miles Franklin and George Ashton, Bert and Dora Birtles, Katharine Susannah Prichard and Gavin Casey and Leslie Rees.

1943 Antidotes to Absenteeism

Happy Mac

Australia - Let's Look Ahead:

C.J. Dennis

Joseph Furphy Speaks

How America Views Our Literature

Our Indigenous Humour

This Changing Australia - Canberra, the Centre

Gurrent Books (25 scripts)

I944 After the War, then What ... (discussion)

Gontrols can Mean Freedom

Current Books (22 scripts)

Writers of Our Time - Knut Hamsun

Dr Stevenson \& Robert Louis Hyde

Great Writers \& Their Ideas:

Cervantes \& Chivalry

Tolstoy \& War

Living in Factories

Australian Writers Speak

I945 Spotlight on Literature:

Moby Dick

Great Expectations

Robert Louis Stevenson

Such is Life

Theodore Dreiser

Current Books (26 scripts)

Writers of Our Time - Louis Couperous

1946 Gurrent Books (18 scripts)

I947 Current Books (23 scripts)

Introducing Australian Literature Overseas - Literature \& the Arts

$194^{8}$ Gurrent Books (24 scripts)

Henry Lawson

1949 Literature \& the Arts (for South African Broadcasting Corporation)

Armchair Chat: Our Homely Heritage of Song; Impersonally

Speaking; If I Were a Youth Again.

Current Books (22 scripts) 
1950 Current Books (25 scripts)

195I A Century of Australian Literature:

Kendall and Gordon; Catherine Spence, Tasma \& Mrs Campbell Praed; William Hay \& Eleanor Dark

Current Books (24 scripts)

Standard Works I'd Like to Burn - Scott's Novels

Fifty Years of Federation:

Literature in this Century

1952 E.J. Brady

Current Books (24 scripts)

I953 Current Books (2 I scripts)

1954 Current Books (13 scripts)

Chekhov and the English-Speaking World

Living Speech

The Legend of the Nineties

Miles Franklin

I955 Current Books (I 6 scripts)

Burton \& His Anatomy of Melancholy

The Fires of St John

1956 Current Books (22 scripts)

Survey of a Century:

The Rise of Australian Nationalism I89o-1919

Travellers' Tales - The Finnish Sauna

Fifty Years of Changing Literature

English Life Today

I957 Armchair Chat - The Writer \& His Audience

An Australian Outlook in Literature - Is it Desirable?

Writers I Remember: A.G. Stephens; Edward Dyson;

Randolph Bedford; Albert Dorrington; A.H. Davis (Steele Rudd); Barbara Baynton.

Today's Books (book reviews) (20 scripts)

1958 Let's Look at Our National Birthday

Today's Books (9 scripts)

1959 Today's Books (6 scripts)

Ancestors

The Black Horse

The Seahawk

The Dingo

The Interloper
PLAYS BROADCAST

1943

1937

$193^{8}$

1939

1940 


\section{Selected Bibliography}

The Little Duck I950

Hail Tomorrow $\quad$ I948 (Adapted by George Farwell)

Christine 1948. (Adapted by George Farwell)

Meadowsweet $\quad 1957 \quad$ (Adapted by Joy Hollyer)

ADAPTATION BY VANGE PALMER FOR BROADCAST

Telling Mrs Baker (Henry Lawson) 1959

FEATURE

Melbourne (for Australian Walkabout Series) 1947

Pearson, W.H., Henry Lawson Among Maoris. Canberra, 1968.

Phillips, A.A., The Australian Tradition. Melbourne, 1958.

- 'Henry Lawson as Craftsman', Meanjin Quarterly, No. 2, 1948.

- 'The Literary Heritage Reassessed', ibid., No. 2, I962.

Press, Jchn (ed.), Commonwealth Literature: Unity and Diversity in a

Common Culture. London, 1965.

Prout, Denton, Henry Lawson: The Grey Dreamer. Adelaide, I963.

Rees, Leslie, Towards an Australian Drama. Sydney, 1953.

Roe, Jill 'Challenge and Response: Religious Life in Melbourne, 1876-86', Fournal of Religious History, No. 2, 1968.

Roe, Michael, Quest for Authority in Eastern Australia. Melbourne, I965.

-'The Australian Legend: An Exchange', Meanjin Quarterly, No. 3, I962.

- An Historical Survey of Australian Nationalism', Victorian Historical Magazine, November, $197 \mathrm{I}$.

Rosenberg, Harold, The Tradition of the New. London, 1962.

Ross, Robert, The Georgian Revolt 1910-1922: Rise and Fall of a Poetic Ideal. Carbondale, 1965.

Sayers, G.E., David Syme: A Life. Melbourne, 1965.

Scott, Enest, Australia During the War. Sydney, 1936.

Serle, Groffrey, The Rush to be Rich. Melbourne, I97r.

-From Deserts the Prophets Come: The Creative Spirit in Australia 1788-1972. Melbourne, 974.

Serle, Ptrcival, Dictionary of Australian Biography, 2 vols. Sydney, I949.

Sinclaire, Frederick.

Books

-Annotations. Melbourne, I920.

- Lend Me Your Ears. Wellington, 1942.

ARTICLES etc.

-'Sociaism and the Churches', Socialist, I May Igo8. 


\section{Selected Bibliography}

-Review article of Kirkup's A History of Socialism, ibid., I9 June Igo8.

-Address to the Melbourne University Literary Society on Bernard Shaw, Melbourne University Magazine, September 1908. -Address to the Social Science Club on the Incarnation, Socialist, 23 October 1908.

- 'Plea for an Adult Theatre', Trident, I December I go8.

- 'The Problem of Prostitution: How to Deal With It', Socialist, 26 February igog.

-Address to the Socialist Party on 'The Shame of the Streets', ibid., 2 I May Igog.

-Address to the Socialist Party on 'Socialism and the Theatre', ibid., 29 July I 9 Io.

-'Music and Socialism', ibid., 26 May I9ı.

-'Belated Shavianism', ibid., 9 June I9I I.

-'Socialism and Music', ibid., I6 June rgr 1 .

-'Socialist Theatre Party: John Gabriel Borkman', ibid., 23 June IgI I.

-'Repertory Theatre: Second Season', ibid., 8 September 1911.

—'Melbourne Repertory Theatre', ibid., 20 October I9I r.

- 'Military Training', ibid., I December 19 I.

-Address to the Repertory Theatre Club on 'The Philosophy of Ibsen', reported in the Bulletin, 25 April 1912.

-'A Doll's House: Ibsen in Melbourne', Socialist, ro May 1912.

—'The People's Books: (Bergson)', ibid., 20 September I9I2.

-'Two Modern Prophets: I - Friedrich Nietzsche', ibid., 4 April IgI3.

-'On the World at War', Fellowship, September I9I4.

- 'Religion and Superstition', ibid., October 1914.

—'Guild Socialism', ibid., September I9I5.

-'Political and Economic Power: Something of Labor's Objective and Guild Socialism', Ross's Magazine, January 1916.

- 'Towards a Living Theology', Fellowship, March 1916.

- 'The War of Ideals', Ross's Magazine, I April I9I6.

- 'Ibsen in His Letters', Repertorian, September 1916.

-'The Two Australia's', Fellowship, November I9I6.

- An Unjust Judgement: Persecution of the I.W.W.', ibid., December Igi 6 .

- 'Notes of the Month', ibid., February I9I7.

- 'Towards a Living Theology', ibid., March 1917.

—'Towards a Living Theology', ibid., April 1917. 
-'Notes of the Month', ibid., September I9I 7 .

—'Sham Idealism: Our Intellectuals', ibid., November I9 8.

- Notes of the Month', ibid., June ig2I.

-'Notes of the Month', ibid., June 1922.

-'Australian Literature: The Outlook', Age, 12 September 1927.

Smith, F.B., 'Spiritualism in Victoria in the Nineteenth Century', Journal of Religious History, No. I, 1965.

Smith, James (ed.), The Cyclopedia of Victoria. 3 vols. Melbourne, I 905 .

Smith, Vivian, Vance Palmer. Melbourne, 1971.

-'Vance and Nettie Palmer: The Literary Journalism', Australian Literary Studies, October 1973.

Stead, G.K., The New Poetic: Yeats to Eliot. London, 1967.

Stephensen, P.R., The Foundations of Culture in Australia: An Essay Towards National Self-Respect. Sydney, 1936.

- Kookaburras and Satyrs: Some Recollections of the Fanfrolico Press. Cremorne, 1954.

Tate, Henry, Australian Musical Possibilities. Melbourne, I924.

Tregenza, J.M., Australian Little Magazines 1923-1954: Their Role in Forming and Reflecting Literary Trends. Adelaide, 1964.

-Professor of Democracy: The Life of Charles Pearson, 1830-1894. Melbourne, 1968.

Turner, F.J., The Frontier in American History. New York, 1948.

Turner, H.G., $A$ History of the Colony of Victoria, From its Discovery to its Absorption into the Commonwealth of Australia. 2 vols. London, 1904 . Turner, Ian, Industrial Labour and Politics: The Labour Movement in Eastern Australia 1900-1921. Melbourne, 1965.

-Sydney's Burning. Revised edition. Sỳdney, 1969 .

- The Australian Dream. Selected and introduced by Ian Turner. Melbourne, I 968.

-'Socialist Political Tactics', Bulletin for the Australian Society for the Study of Labour History, No. 2, I 962.

Walker, David, 'A Bohemian's Progress: Louis Esson in Melbourne, 1904-1914', Meanjin Quarterly, No. 4, 1972.

Ward, Russel, The Australian Legend. Sydney, 1958.

- Australia. Sydney, 1965.

—with John Robertson, Such was Life: Select Documents in Australian Social History. London, 1969 .

-'Felons and Folk-songs', Meanjin Quarterly, No. 3, 1956.

-'Vance Palmer: Homo Australiensis', Meanjin Quarterly, No. 2, 1959. 


\section{Selected Bibliography}

-'The Australian Legend: An Exchange', Meanjin Quarterly, No. 3, Ig62.

- 'Two Kinds of Australian Patriotism', Augustus Wolksel Memorial Lecture, September 1969.

Wighton, Rosemary, 'G.J. Dennis and the Gadfly', in Dutton, G. and Harris, M. (eds.), The Vital Decade: Ten Years of Australian Art and Letters. Melbourne, 1968.

Williams, Raymond, Culture and Society, 1780-1950. London, 1963.

-Wilmot, Frank. The Long Revolution. London, I96r.

\section{BOOKS}

-Unconditioned Songs [Anon]. Melbourne, 1913.

-To God: From the Weary Nations. Melbourne, I9I 7.

-Eyes of Vigilance: Divine and Moral Songs. Melbourne, 1920.

-Arrows of Longing. Melbourne, 1921.

-Romance. Melbourne, 1922.

- The Gully and Other Verses. Melbourne, 1929.

- Melbourne Odes. Melbourne, 1934.

-Poems of Furnley Maurice (Frank Wilmot). Selected by Percival Serle. Melbourne, 1944.

ARTICLES etc.

—'The Song of Socialism' (poem), Tocsin, 9 June 1898 .

—'The Fatman's Song' (poem), ibid., 23 June 1898.

-'Lead On' (poem), ibid., 14 July I 898.

- 'A Cigarette Dream' (short story), Microbe, February 1902.

-'Joseph Conrad, Novelist',* Book Lover, I November I904.

-'Joseph Conrad, Novelist', * ibid., I December I904.

-'The Mystery of Progress', * ibid., I November 1905.

-'The Kept Poet', Bulletin, 7 February 1907.

-'The Merry Poet', Trident, I July Igo8.

- 'Veneer' (poem), ibid., October 1908.

- 'The Cloud of Sentiment', ibid., I January I 909.

- 'Minor to Major (Edmund Spenser, I552-1599)' (poem), Thrush, March Igio.

- 'Whitewash', Sydney Worker, 31 March rgio.

- 'Perils and Dreams', Lilley's Magazine, 7 September IgI I.

-'Joseph Conrad', Lone Hand, November I9ı2.

- 'Rupert Brooke', Book Lover, I May Igi 6.

-'To God: From the Weary Nations' (poem), ibid., December IgI 6.

—'Headsmen to the Light' (poem), Birth, January 1917. 


\section{Selected Bibliography}

-'Some Celtic Writers and the Geltic Movement', Triad, April Igr 7 .

-'Some Geltic Writers and the Celtic Movement', ibid., May 1917.

-'The Green Spot' (poem), Fellowship, February 1918.

_-'Violence and Ideas and Patience', ibid., February I918.

-'Echoes' (poem), ibid., August 1918.

- 'National Poetry', Book Lover, 2 I May 192 I.

- 'Encouraging Australian Poetry', Bulletin, I9 May 1927.

—'Status for Writers', ibid., I I August 1927.

*These articles were not included in Anderson, Frank Wilmot.

Wright, Judith, 'The Upside-down Hut', Australian Letters, No. 4, ig6r.

D. THESES ETC.

Baracchi, Guido, typescript of interview held by author.

Blackburn, Susan, 'Maurice Blackburn and the Australian Labor Party, 1934-1943: A Study of Principles in Politics', B.A. thesis, University of Adelaide, 1968.

Carter, Philip, 'Victor Daley: Man and Poet', M.A. thesis, University of Adelaide, 1970.

Clarke, S.B. 'Vance Palmer: A Consideration of His Career in Australian Letters', M.A. thesis, Sydney University, 1967.

Cole, S.M., 'Gentlemen and Guardians: An Inquiry into the Relationship between the Study of Literature and the Study of History, Based on the Novels of Evelyn Waugh', B.A. thesis, University of Adelaide, 1969 .

Coward, Dan, 'The Impact of War on New South Wales; Some Aspects of Social and Political History 1914-191 7', Ph.D. Thesis, ANU, 1974 .

Davison, Graeme, "The Rise and Fall of "Marvellous Melbourne" I880-I 895', Ph.D. thesis, A.N.U., I969.

Kenafick, K.J., 'The Life and Work of R.H. Long: Australian Poet', manuscript, Melbourne, r957. M.L.

Keogh, Esmond, taped interview.

McKernan, Michael, 'W.H. Judkins and the Social Reform Movement, Melbourne, I906', B.A. thesis, ANU, I97I.

Norris, Ron, 'The Emergent Commonwealth, I9o I-10. A Study or Reappraisal of Aspects of the Developments of Federal Government with Some Attention to the Expectations of the Founders and the Actual Exercise of Federal Power', Ph.D. thesis, ANU, I970. 


\section{Selected Bibliography}

Osborne, Graeme, 'Tom Mann: His Australasian Experience 1902-1910', Ph.D. thesis, ANU, 1972.

Osmond, Warren, 'The Education of a Victorian Liberal : Frederick Eggleston $1875^{-1916}$, M.A. (Hons.) thesis, University of Sydney, 1974.

Palmer, Helen, taped interview.

Smith, F.B., 'Religion and Free Thought in Melbourne, 1870-1890', M.A. thesis, Melbourne, 1960.

Walker, David, 'Writer and Community: Vance Palmer, Louis Esson, Frank Wilmot and Frederick Sinclaire, 1905-1930', Ph.D. thesis, ANU, I972.

Waters, Edgar, 'Some Aspects of the Popular Arts in Australia', Ph.D. thesis, ANU, 1962. 


\section{Index}

Abbey Theatre Players, 137, 145

Abbieglassie station, see Palmer, Vance (at Abbieglassie)

$\mathrm{ABC}, 19,164$

$A B C$ Weekly, 9, 217

Aborigines, see Palmer, Vance (and Aborigines)

Adams, Arthur, 22

A Doll's House, 88

Age, the, 71, 137, 158, 162

A.I.F., 91, 119, 135, 213

A Happy Family, 137, 138, 139

All About Books, 216

America: Esson's opinions on, 135, 155; films, 137, 143-5; I.W.W., 102; journalism, 38, 213, 214; national character, 104; nationalism, 205; poetry, 127; social life, 51 ; suburbia, 151

An Australian Perspective, 201-2

Andrews, Eric, 161

A New Britannia, 206

Angus and Robertson, 215, 217

Anti-Conscription Army, 113

Anti-Sweating League, 87

ANZAC, 8, 157, 195

Argus, the, 27, 71, 73, 78-9, 80, 83, 106-9, 128, 137, 144, 157, 158, 182, 215

Ashe, Oscar, 139

Ashton, Julian, 3

Asia, 1, 21; fear of, 19, 20

Asmis, Dr, 163-4

Aussie: the Cheerful Monthly, 214

Australasian, the, 42, 128, 139-43, 145, 148

Australia: as 'servile state', $52,102-3,194$; creativity in, 33,96 ; disillusion with, $8,9,27,51,59,72,119-20,133,153-5,165,197,211$; five worst citizens of, 82 ; future of, $5,7,8,12,20,21,29,33,34,56,58,60,61,70$, $88,89,90,98-9,105,121,122,123,124,125,128,165,189$, 192; lack of tradition, $7,8,21,33,34,49,57,150,151,166,183,199,202,206$; mediocrity of, $6,12,13-14,22,24,26,30,34,37,49,61,64,67,120-1$, $125,135,146,148,150,151,152-3,160,161,164,165,167,192,197$, 199, 208; 'Two Australias', 97-100, 105, 108, 120, 122, 148, 166-7, 194, 195, 205.

Ausiralia, ed. C. Hartley Grattan, 208

Australia, W. K. Hancock, 204

Australian: audiences, $141,142,143,145$; character, 11, 40, 43, 46, 69, $99,104,138$; cities, $3,8,24,29,34,121,166,182,183,184$; civilisation, $7,18,207$; colonialism, $6,7,8,30,31,33,34,35,98,101,106,141,142$, $167,201,202,208,211$; creative artists, $3,6,22,121$; creative arts, 


\section{Index}

31, 33; defence, 19; drama, 2, 11, 13, 17, 27, 29, 77, 88, 134-45 passim, 199; film, 145; history, 10, 99, 100, 201, 205, 209; landscapes, 21, 57; legend, 207, 209; life, 32, 33, 34, 59, 96, 98, 99, 121, 126, 144, 147, 151, $183,184,201,209$, 210; literature, 1, 16, 22, 23, 31, 34, 50, 66, 67, 127, 134, 153, 173, 187, 199, 201, 203, 207-8, 216; national culture, 1, 10, $34,50,59,143,145,208$; nationalism, 18, 19, 32, 100, 112, 114, 136, 210, 231; nationhood, 15, 192; patriotism, 5, 51, 57, 91, 107, 108, 203; people, 1, 5, 59, 70, 90, 95, 99, 162, 164, 165, 177, 195, 197, 206; poets, $16,23,126,127,136$; politics, $5,14,27,72,117,192$; society, $1,5,6,8$, $27,29,49,78,79-80,89,96,100,121,126,131,160,161,196,197$, 199, 200, 201, 202, 205, 206; soldiers, 119, 157, 195; speech, 143; themes, $12,29,30,32,38,40,47,59,61,66,146,204$; spirit, 5, 90, 117; working man, $24,52,132$; writers, $6,7,8,9,21,32,33,37,66,118,126,127,165$, $177,186,197,199,200,208,213,214,216$

Australian Academy, 200

Australian and New Zealand Authors' Week, 200

Australian Literature Society, 6, 17

Australian Church, 87

Australian Fournal, 216

Australian Labor Party, see Labor Party

Australian Natives Association, 97

Australian Peace Alliance, 98

Australian Theatre Society, 17

Australian Worker, 105

Australian Writers' and Authors' Guild, 2, 199

Australians, 18, 26, 49, 81, 90, 104, 120, 125, 128, 134, 139, 148, 150, 152, $161,165,174,177,186,195,196,203,211$

Australians in Spain, 161

Badger, C. R., 87

Ball, W. Macmahon, 158

Balzac, H., 36, 37, 56

Banks, Norman, 163

Baracchi, Guido: and nationalism, 112; and Sinclaire, 229; and Victorian Labour College, 112; anti-conscription views, 112-13; comforts Palmer, 196; jailed, 113; Marxist, 129, 130; Socialist opposition to war, 106-7, 232 ; student radical, 93, 95; views criticised, 107-12

Barnes, John, 31, 32

Bean, C. E. W., 40

Bedford, Randolph, 32

Belloc, Hilaire, 48-9, 160

Bergson, H., 7, 29, 55, 87, 210, 219

Big Budget, 62

Bijou Theatre, 63, 75, 78

Birth, 2, 116, 133

Blackburn, Maurice, 112, 163

Blainey, Geoffrey, 95

Boer War, 35, 38

Bohemia, 1, 17, 19, 22, 66, 194 


\section{Index}

Boldrewood, Rolf, 33

Bolshevism, 133, 156

Book Censorship Abolition League, 158, 161

Book Lover, 114, 116, 133

Boote, Henry, 105

Boucicault, Dion, 141, 142

Brady, E. J., 16, 21, 86, 146, 199, 220

Brennan, Christopher, 116, 117

Brisbane, 37, 146

Britsh Empire, 1, 4, 108, 110, 111, 114, 157

Brodzky, Maurice, 17

Brodzky, Leon (Spencer Brodney), 17, 20, 22, 28, 219, 220, 221

Brooke, Rupert, 68-9, 70

Bruce, S. M., 133

Bruce-Page Government, 133, 156

Bruce, Mary Grant, 148

Bull, Hilda, see Esson, Hilda

Bulletin, the, 3, 4; and Russo-Japanese War, 19; criticism of, 22-3, 35, 67, 126, 152, 216; democratic tradition, 197; Esson reviewed in, 28; racism,

19; Wilmot reviewed in, 116; see also under individual contributors

bush, the, $5,17,21,28,32,34,39-40,50,127,128,176$

bushmen, 1, 14

Buvelot, Louis, 13

Byrne, Gerald, 137

Cambridge, Ada, 33

Campion Society, 162

Cape, Jonathon, 159

capitalism, 61, 89, 92, 100, 102, 109, 128, 132, 206

Carlyle, Thomas, 88

Carpenter, Edward, 7, 89-90, 95, 178, 192, 210

Gatholic Action, 162, 163

Catholicism, 48

Catholic Worker, 162

Celtic Movement, 69-70; see also Irish literary movement

censorship, 145, 156, 158-61, 164, 201, 237

Central Labour College, 112

Champion, H. H., 116

Chesterton, Cecil, 49

Chesterton, G. K., 6, 32, 48, 49, 50, 57, 210

Childe, V. G., 204

Christianity: and socialism, 72-3, 75-6, 79, 84,' 109; as 'Great Scaly Plague', 4; criticised, 25, 53, 72-3, 78, 83, 86, 118 ; Macartney's church attendance, 85-6; Menzies defence of, 111; Sinclaire's belief, 74-5, $76-7,79,83,88,94,98$; the Churches, 1, 72-3, 81, 85, 91, 97, 98, 204; the Palmers' beliefs, $84-5$

Christesen, C. B., 11, 31

cinema, the, $134,138,142,143,144-5,152,155,235$; see also Australian film 


\section{Index}

cities, 5, 29, 33, 51, 64, 67, 121, 146, 148, 149, 176, 179-80, 182-4, 236; see also suburbia; Australian cities

civilisation, $85,89,93,101,111,114,121,124,128,147,152$

Civilisation: Its Cause and Cure, 89

Civil liberties, 156, 161, 201; see also Council for Civil Liberties

classicism, 94, 97

class war, 40,121

Clayfield Grammar School, 39

Cole, E. W., 62

Cole, Margaret, 160

Coleman, Peter, 204

Cole's Book Arcade, 62, 63, 199

Collins, Tom, see Furphy, Joseph

Comic Cuts, 62

commercialism, 1, 8, 58, 115, 144

common man, the, 47, 49, 53, 59, 89, 94, 154, 155, 172-3, 186, 203

Commonwealth Literary Fund, 9-10, 217

communism, 130, 155, 159, 162

Communist Party, 162, 187, 206

community, 5, 46, 49, 59, 89, 99, 128, 134, 136, 151, 190, 193, 204, 207, 211

Congregational Church, 62

Congress of Writers for the Defence of Culture, 160

Connell, R. W., 205

Conrad, Joseph, 64-5

conscription : anti-conscription campaign, 112-13, 122-3; Baracchi arrested, 113-14; defeat of, 90, 97, 98, 108, 117, 196; Palmer's views on, 104-5,

119; referendums, 97, 98; Sinclaire's opposition to, 87, 97-100

conservatives, 14, 24, 72, 128, 133, 200

cosmopolitanism, 99, 101, 123, 142, 148, 178, 200

Council for Civil Liberties, 161, 164

Courier, Brisbane, 216

Cox, Stanley, 38, 224, 226

Country Party, 133

craftsmanship, 5, 45-6, 49, 56, 59, 62, 128, 179, 180, 199

Crawford, R. M., 192, 201-2, 205, 209

Criminological Society, 87

Cronulla, 170, 217

Current Affairs Bulletin, 144

Cusack, Dymphna, 154, 155

Cyclone, 217

Daley, Victor, 3, 16, 19

Dangerfield, George, 44

Dark, Eleanor, 177

Davison, Frank Dalby, 165

Dead Timber, 28

Deakin, Alfred, 5, 19, 72

Deeds that Won the Empire, 79, 228

de Maupassant, Guy, 36 
democracy, 53, 79-80, 105, 120, 122, 153, 161, 164-5, 177, 189, 194, 195, 198-9, 210

Denham, Digby, 183

Dennis, C. J., 148

Depression, the, 133, 157, 188

distributivists, 48,49

Dorrington, Albert, 19, 37-8, 221

drawing room artificiality, 38, 47, 134, 174, 176, 192, 198

drink: and Bohemia, 19; Esson recommends, 25; evils of, 19, 81-2, 86; temperance, 86

Duncan, Isadora, 48

Dyson, Will, 152, 166

Dyson, Edward, 216

Earsman, W. P., 112

Eastern Hill Unitarian Church, 2, 39, 76, 86, 87, 88, 158

egalitarianism, 205-6, 207

Eggleston, Frederick, 10

Elliot, Gertrude, 141

Encel, Sol, 191, 204, 205

England: and socialism, 46, 47, 51, 52, 90; deference to, 95-6, 98, 99; influence of, 210-11; labour unrest, 44; Palmer patronised, 49-51, 57, 89; Palmer's attitude to, 59, 189, 207; Pound's criticism, 51; social polarisation of, $46,59-60,90$

English: culture, 128, 160; folk traditions, 47, 48, 49, 57, 58, 59; middle class, 47-8, 173-4, 177; national character, 47-8, 57, 61, 69, 210-11; poetry, 68, 127; theatre, $139,141,142$

Equality and Authority, 205

Esson, Hilda, 2, 95, 123, 134, 136, 146, 175, 216

Esson, Hugh, 29, 136, 155, 200

Esson, Louis: admires Bergson, 7, 29; and Bohemia, 16-17, 19, 22; and socialism, 15, 17, 23-4, 26,71,72, 77, 89; and World War I, 195; attitudes on (Europe) 21-2, (Labor Party) 14-15, (Church) 25, 82, (newspapers) 25, (parliament) 25-6, (slums) 24-5; at Mallacouta Inlet, 16, 18, 146; at university, 95; celebrates drink, 25; compared to Wilmot, 6, 7; concentrates on drama, 28; contributes to (Bulletin) 11, 14, 15, 18, 19, 20, 23, (Fellowship) 73, (New Triad) 146; criticises (Australia) $14,26,30,121,134,142-3,146,149,152,165$, (Bulletin) 22-3, (Marxists) 129, 222, (Melbourne) 4, 29, 137, 146, (middle class) 24, (Shaw) 28-9; difficulties as Australian writer, 8-9, 13, 20, 35, 66, 177; disappointment with Pioneer Players, 134, 137, 146; disillusion, 154-5, 211 ; early poetry, 15-16; first meets Palmer, 2; founder of Australian drama, 11, 199; good resolutions, 20; hears Kisch, 159; in New York, 134; Irish influences, $12,14,17-18,64,135-6,210$; meets Macartney, 86; member (Book Censorship Abolition League) 158, (V.S.P.) 2, 222; nationalism, 11-12, $14,29,30,32,39-40,134$; O'Dowd's influence on, 12, 23, 136; patriotism, 19-20, pot-boiling, 214; relies on Hilda financially, 216; returns to Australia, 136; stops writing, 8, 155; upbringing, 13, 29; views on Australian future, $5,21-2,32,33,61$; visits Paris, 13-14 


\section{Index}

Europe: and World War I, 117; Australian dependence on, 95, 96, 98-9, 124, 128, 160; effete nature, 21, 124-5; fascism in, 148, 160, 200 ; postwar, 115, 122, 127, 128

Evans, Essex, 35

Evatt, H. V., 204

Eyre, Laurence, 142

Fabian Society, the: and Georgian poetry, 68; and H. G. Wells, 38; inadequacies of, 44, 45, 48, 49, 93; in Melbourne, 76, 228; Palmer's views on, 38-9, 41, 45, 52-3, 93, 95

Fane, Maude, 138

Farrago, 163

fascism, 148, 156, 160,162, 163-4, 165, 177, 188, 200

Fasoli's Café, 16-17, 39, 86

Fellowship: and guild socialism, 93; and Tomorrow, 153; contributors, (Esmonde Higgins) 102, (Esson) 136, (Rev. C. Strong) 87, (Sinclaire) 93, 102, 104, 205, (Vance Palmer) 93, 103, 119, 121, (Wilmot) 114, 117, 125; first number, 93; last number, 133; Sinclaire as editor, 73, 230

Fights for the Flag, 79, 228

film, see cinema

Fisher, Andrew, 91, 97

Fitchett, Rev. W. H., 4, 79-8I, 83, 197, 228

Fitzhardinge, L. F., 122, 231

Fitzpatrick, B., 10, 159, 164, 189, 204

Flaubert, G., 36, 67

folk culture, $5,34,46,49,57,134,138,146,192$

For the Term of his Natural Life, 33

France, 91, 108, 119, 124, 173

Free Religious Fellowship, the, 2-3, 73, 87, 92, 112, 119, 205

From Deserts and Prophets Come, 207-8

Furphy, Joseph, 31, 32, 34, 197, 203

Gadfly, 19, 82

Gaiety theatre, 63,82

gambling, 19, 25, 81

Gellibrand, Sir John, 157

Geoffrey Hamlyn, 33

Georgian Poetry, 68

Germany, 108, 109, 116, 119, 155, 195

Giblin, Professor L. F., 158

Golconda, 190, 217

Gollan, Robin, 206

Grattan, Hartley, 165, 208

Green, H. M., 11, 31

Gregory, Lady, 17

Gregory, Professor, 104

Grossmith, Lawrence, 141

guild socialism: and Baracchi, 106-7, 110, 112, 113; and Pioneer Players, 134; and Irvine, 96; and 'Servile State', 48, 52, 104; and Palmer, 


\section{Index}

5, 45, 49, 56, 93-4, 198-9, 230; criticised by Higgins, 131, 133; failure of, 127, 160; in Italy, 211; not Internationalist, 49, 50; principles of, 45-6, 225; recommended for Australia, 52-3

Hail Tomorrow, 217

Hamilton, Sir Ian, 157

Hancock, Professor Sir Keith, 31, 204

Hassell's Australian Miscellany, 208

Heart of the Rose, 21

Hemingway, Ernest, 157

Herald (Melbourne), 19, 132, 158

Herbert, Xavier, 177-8

Hervey, Grant, 19

Heseltine, H. P., 31, 168, 181, 202-3, 207

Higgins, Esmonde, 52, 213, 214; and Marxism, 129-31, 187; and M.U.M., 106; and Sinclaire, 131, 133; and World War I, 91-2, 100, 114; as model for Ernest Swayne, 183-4, 187; at university, 95; contributes to Fellowship, 115; friend of Hancock, 205; nationalist, 101-2, 106, 187, 231

Higgins, Henry Bournes, 39

Higgins, Nettie, see Palmer, Nettie

Hobson, S. G., 93

Hope, A. D., 168

Hughes, W. M., 97, 100, 102, 122-3, 195-6

Hurricane, 214

Huxley, Aldous, 8

Hyatt, Frank, 84

Ibsen, Henrik, 87, 88, 210

Imperial Federation, 105, 106

imperialism, 24, 91, 100-1, 105

Independent Labour Party, 45

industrial democracy, 45, 52, 93, 103, 104, 112

industrial disputes, 4, 52, 71-2, 80, 103-4, 132

industrial society, $5,8,43,45,48,49,64,67,87$

Ingewersen, S. J., 162, 163

Inglis, K.S., 8, 219

internationalism, 103-4, 123, 131

Ipswich Grammar School, 35

Ireland, 119, 136

Irish: character, 69; drama, 17-18; literary movement, 210

Irvine, R. F., 96-7, 230

I.W.W., 100, 102, 113

Japan, 19, 108

jazz, 138, 149, 151

Jellie, Rev. William, 74

jingoism, 91-2, 110, 111, 122

John Blake, 137 


\section{Index}

Johnston, George, 157

Joint Spanish Aid Council, 161, 162

Judkins, Rev. W. H., 81-2, 83, 228

Kelly, K. T., 162, 163

Kemp, Margaret, 158

Kendall, Walter, 44

Kisch, Egon, 159, 160, 237, 238

Labor Daily, 163

Labor Government, 91, 158

Labor Party, 14, 71, 97-8, 206-7

labour movement, 51-2, 60, 71, 101, 105, 114, 132, 204, 205

Labour Party (Britain), 44

Larapinta, 148-9

Lawrence, D. H., 32, 151, 198, 204

Lawson, Henry, 12, 14, 19, 21, 25, 31, 32, 34, 35, 154, 187, 203, 204

Legend for Sanderson, 178, 188, 189, 214

Let the Birds Fly, 168, 214

Lindsay, Jack, 168

Lindsay, Lionel, 37, 38

Lindsay, Norman, 3, 158

London, 37-8, 42-3, 49, 50, 51, 91, 119, 134, 135

Long, R. H., 112

Lyons, Joseph, 160, 163-4

Macartney, Frederick, 85-6, 127, 150, 216, 226, 229, 236, 243

McGrae, Hugh, 3, 16, 18, 21

McKay, Hugh, 4, 22-3, 149-50, 219, 221, 222

Macky, Stewart, 137, 147

McMahon, Gregan, 25, 87

McQueen, Humphrey, 206, 241

Mann, Leonard, 165

Mann, Tom, 71, 72, 73, 75, 76, 227

marriage, 168, 171, 172, 175-6, 191

Marshall, Alan, 138

Marshall, Rev. Dr, 73

Marx, Karl, 77, 130, 132

Marxism, 77, 127, 129-32, 155, 162, 187, 206

Meanjin Quarterly, 2, 9, 30, 167

Melbourne: as drama centre, 119; audiences 134,141 ; dislike of, 3, 30, 138, 182, 186; land boom, 3; Literary Club, 127, 219; night life in, $82-3$, 138; poverty, 71 , 73; repertory theatre, 87-8; slums, 24-5; socialists, 40, 41, 63, 71; University, 13, 92, 95, 96, 109-10, 205, 230; University Historical Society, 110; University Press, 199

Melbourne University Magazine, 106, 109, 110-11

men: manhood, 104, 111 ; manliness, 5, 173-4, 176-7, 187-8, 189, 196, 199; novels for, 173, 188

Men are Human, 170, 172, 216

Mencken, H. L., 198 


\section{Index}

Menzies, Sir Robert Gordon, 110-11, 161, 232

Merry Widow, 139-40

Methodist Church, 81, 85, 86

Microbe, 63, 64

middle class : background of Palmer's characters, 72-3; criticised 8, 24-5, $32,48,53,54,89,98,99,114,134,192,197-8$; Esson's background, 30;

Palmer defines values of, 54; Palmer not offensive to, 198; rejection of,

195; underestimated, 204

militarism, 100, 101, 115

Minogue, Henry, 106

Mirror, 215

Modern Australian Literature, 2

modernism: cubism, 128; free verse, 128; Heseltine and, 203; opposition to, $61,67,81,127,128,143,149,150,151,173$; post-war, 138, 211 ;

Wilmot and, 68-9, 126; see also cinema; jazz

Moncrieff, Gladys, 138, 139

Moore, George, 36

Moore, Harrison, 95

Moore, William, 135, 234

morality, 78-83, 198

Morris, William, 8, 62, 88, 155

Mother and Son, 137

Movement against War and Fascism, 159

Mulgan, Alan, 137

Munro, H, 68

Murdoch, Walter, 2, 10, 151-2, 153, 219, 229, 233, 236

Murray, Gilbert, 155

musical comedy, 138-40

national: consciousness, 43, 49, 98-9, 127, 199, 205; culture, 1, 47, 50, 59, 95, 104, 114, 115, 194, 199, 201, 211

National Guilds, 93, 106

nationalism: and literary critics, 31-2, 202, 211 ; see also under individuals

Nationalist Party, 98

National Portraits, 9, 217

National Security Act, 164

New Age: anti-Fabian, 48-9; and Baracchi, 106; and Esmonde Higgins, 131, 133; and Ezra Pound, 51; and Menzies, 111; and national literature, 47-8; and Orage, 7, 46-7, 133; and 'Servile State', 48; literature on, 225 ; see also Palmer, Vance (and $\mathcal{N} e w A g e$ ); Sinclaire, Frederick (and New Age)

New Guard, 160

New Triad, 146

New Zealand, see Sinclaire, Frederick (and New Zealand)

Nietzsche, Friedrich, 53, 87, 101, 210

North Fitzroy State School, 62

O'Dowd, Bernard, 219; and Australia's future, 8, 21; and Melbourne (Fabian Society) 76, (Literary Club) 127; and Nettie Higgins, 39, 85; 


\section{Index}

and Palmer, 32, 58; and socialism, 85; and V.S.P., 2, 39, 71; and Wilmot, 63, 67; formative literary influence, 6-7; influences Esson, 12, 23, 136

O'Ferrall, Ernest, 137

Odets, Clifford, 163

One Big Union Herald, 132

Orage, A.R., 7, 46-7, 49, 64, 96, 99, 131, 133, 210, 219

Orwell, George, 8, 160

Osborne, C.G.W., 227

Osmond, Warren, 205-6

Overland, 9

Owen, Harrison, 199

pacifism, 116, 157

Palmer, Aileen, 156, 201

Palmer, Henry, 36, 41-2

Palmer, Nettie: and Aileen, 201; and Australian conservatism, 160, 165; and Baracchi, 130; and censorship, 157, 158, 160; and Christianity, 84-5; and Hilda Bull (Esson), 2, 123; and Katharine Prichard, 130; and lack of Australian traditions, 166; and Marxism, 129-31 ; and Meanjin, 31; and Melbourne Literary Club, 127; and Melbourne University, 2, 39, 95; and New Guard, 160; and O'Dowd, 39, 42, 63, 85; and Pioncer Players, 146; and P.L.C., 2, 39; and Sinclaire, 40, 86; and Sir Keith Hancock, 205; and socialism, 40, 41, 76, 84-5, 91; and Spanish Civil War, 161-3; and suburbia, 157; and The Man Hamilton, 171; and The Passage, 182; and The Swayne Family, 183; and World War I, 91-2, 100, 156; Australian delegate, 160; contributor to $(A B C$ Weekly) 9, (Meanjin Quarterly) 9, (Overland) 9; financial contribution to Palmer income, 215, 216, 217; honeymoon, 91; letters (from Vance) 34, 37, 38-9, 40, 42, $43,46,50,51-2,53,56,57$, (to Esmonde) 56, 91-2, 129-31, 183, 214, 216; marriage, 43, 91; nationalism, 92, 131; relationship with Vance, $56,84-5,174-7,197$; smeared as communist, 162 ; takes private tutoring, 213, 242 ; visits Europe, 155-6

Palmer, Vance: and Aborigines, 55, 170, 171; and academics, 94-5, 106, 198; and Australian literature, 33-4, 199; and censorship, 156, 158, $160,161,164,201$; and Christianity, 84-5; and common man, 9, 53, $172-3,188,198$; and conscription, 98, 105, 108, 112, 114, 195-6; and Council for Civil Liberties, 161, 164; and difficulties of Australian writers, 9, 37, 66, 121; and English patronage, 49-51, 89-90; and Esmonde Higgins, 184, 187; and Esson, 2, 13, 33, 67, 71, 135, 136, 146, 199; and Fabians, 38-9, 45, 52-3, 95; and fascism, 148, 160, 165, 177, 200 ; and father, 36, 41-2; and femininity, 5, 56, 168, 169, 173-7, 187, 189; and Fitzpatrick, 164, 189; and folk culture, 5, 34, 46, 49, 57, 151, 166,192 ; and guild socialism, $5,45-6,49,50,53,93-4,96,104,106$, 127, 199; and his generation, 1-2, 72, 95; and imperial federation, 105-6; and I.W.W., 102-3; and labour movement, 51-2, 60, 103-4, 105, 164, 191; and literary critics, 31-2, 168, 181, 208; and London, 37-9, 42-60 passim, 135; and manliness, 5, 54, 56, 104, 168, 169, 171, $173-7,187-8,196,197,199$; and Marxism, 127, 129, 131; and Melbourne, 1-2, 4, 183, 186; and Melbourne Literary Club, 2; and Menzies, 


\section{Index}

111 ; and middle class, $54,114,173-4,184,185,186,192,195,197,198$; and modernism, 58, 127, 151, 178, 180, 197; and nationalism, 34, 41, $49,50,59,90,95-6,99,103-4,105-6,119,120,123,135,167,187$, 189, 192, 194-7, 198, 200, 201, 208; and Nettie, 39, 51, 56, 174-6, 197, 216; and New Age, 5, 45, 46, 49, 54, 64, 90; and O'Dowd, 2, 39, 42, 58, 85; and Orage, 46, 49, 64, 225; and Pioneer Players, 2, 119, 134, 199; and 'Servile State', 48, 52, 156, 160; and Sinclaire, 84-5, $86,88,99,102,104,119$; and socialism, 39, 40-1, 45, 71, 89, 90, 112, $126,128,184$; and Spanish Civil War, 155-6, 188; and suburbia, 8, $121,122,151,161,164,166,176,183-4,186,196-7,198,211$; and the bush, 5, 176, 189, 199; and the city, 5, 121, 166, 176, 179-80, 181, $182-4,186,187,193,196,200$; and the eighteen-nineties, 31-2, 121-2, $127,191-3,196,197-8,201$; and the thirties, $8,155-6,177,185,189$, 200; and Wilmot, 2, 71; and women, see and femininity; and World War I, 90-1, 92, 100, 114, 119, 122, 124-5, 126, 156, 164, 172, 178, 184, 194, 213, 233; and World War II, 217; and Y Glub, 2; as Rann Daly, 120, 214; as school teacher, 39; at Abbieglassie station, 39-42, 44, $50,54,176,183$; broadcasts, 9, 219, 220, 223; contributions to ( $A B C$ Weekly) 9, 217, (Adventure) 54, (Advocate) 119, 213, 233, (Argus) 215, (Aussie) 214, (Australia) 233, (Bellman) 53, (Bulletin) 213, 216, 243, (Fellowship) 3, 73-4, 93, 94-5, 103, 121, (Illustrated Sunday Magazine) 53, 54, (Meanjin Quarterly) 9, 167, 223, (Mirror) 215, (New Age) 54, (Overland) 9, (Pals) 214, (Socialist) 52-3, 102, (Steele Rudd's Magazine) 33, 56, (Sunday Chronicle) 53, (Worker) 103-6; critical of Australia, 61, 119-20, 127, 161, 164, 165-7, 196, 199; despises Rev. W. H. Fitchett, 4, 195; early life, 35-6, 121; hears $K$ isch, 159-60; literary influences, 35-6, 48, 89-90, 178, 210; novels, 170-91 passim; plays, 170, 190; poetry, 56-9, 120, 123-5, 150; pot-boiling, 53-4, 213-17, 242-3; refuses O.B.E., $31,222-3$; sales figures, 9,217 ; short stories, $54-6,168-70,225$; special issue of Meanjin, 31

Pals, 214

Passmore, J. A., 7, 219

Paterson, A. B., 35

Paterson, James, 13

Paterson, John Ford, 13

patriotism, 8, 21, 35, 50-1, 57, 59, 79, 81, 91-2, 102, 158, 195, 203

Peace Society, 87

Penton, Brian, 165, 177

Phillips, Arthur, 11, 31, 32, 47, 203-4, 207, 209

Pinero, Arthur, 142

Pioneer Players, 2, 119, 134-47 passim, 183, 199, 235

Pitt, Marie, 73

Pleasant Sunday Afternoons, 81

Plowman, R. B., 148-9

'poetry militant', 6, 23, 67

Poetry Review, 68

popular culture, 8, 49, 138-9, 142-5, 152

Pound, Ezra, 51

poverty, 73, 78-9, 80, 83 
Poz, 75

Praed, Mrs Campbell, 33

Presbyterian Ladies' College, 2, 39

Press, the (Christchurch), 153

press, the, 53, 91, 97, 98, 127, 128

Prichard, Katharine Susannah, 10, 119, 130, 137, 171

prostitution, 77-8, 82

Public Questions Society, 205

Queensland, 35, 39, 99, 104, 122, 154, 178

Quinn, Roderick, 16

Red Gums and Other Verses, 28

Redheap, 158

Reid, Sir George, 72

religion, see Christianity

Rentoul, Professor J. Laurence, 83

Repertorian, 87

Rickard, J., 71

Robbery under Arms, 33

Roe, Michael, 209-10, 241

Ross, Robert, 68

Ross, R. S., 129

Ross's Magazine, 133

Round Table, 106

Rudd, Steele, 35, 37

Russell, George, 119

Russia, 39, 130, 155, 187

Russian revolution, $127,129,130$

Russo-Japanese War, 19

Santamaria, B. A., 162, 163

Scots Church, 73

Scott, Professor Ernest, 95

Seedtime, 190, 217

Serle, Geoffrey, 31, 206, 207-9, 219, 223, 241

Serle, Percival, 2, 117

'Servile State', 48, 52-3, 102, 103, 160, 194

sex, 82-3, 150, 174

Shaw, G. B., 6, 29, 32, 37, 48, 75, 77, 87, 88, 156, 210

Sinclaire, Frederick: and conscription, 87, 90, 97, 98-100, 105, 109, 112-13; and Esmonde Higgins, 92, 131-2; and Esson, 2, 73; and Fellowship, 3, 73, 92, 93, 94, 102, 104, 133, 205; and Fitchett, 79-81, 83, 195; and Free Religious Fellowship, 3, 73, 87, 153, 205, 229; and his generation, 1, 89, 153; and Judkins, 81-3; and Mann, 75-6; and Marxism, 77, 129, 131-2; and Melbourne Fabian Society, 76; and Melbourne Literary Club, 3, 127; and morality, 77-83 passim; and nationalism, 97-102, 123, 205; and Nettie Palmer, 3, 39, 84; and New Zealand, 75, 86-7, $153,199,227$; and socialism, 2-3, 75-6, 77, 78, 83-4, 88, 89, 93, 97, 


\section{Index}

101, 112; and theatre, 77, 87-8; and Unitarian Church, 2, 39, 76, 87, 88; and Vance Palmer, 3, 39, 73, 84, 93-4, 104-5, 119, 151, 182, 195; and Victorian Labour College, 112; and V.S.P., 2, 73-4, 75, 83-4, 88; and W.E.A., 153, 236; and Wilmot, 73; and World War I, 97, 101, 114, 126, 153, 195, 232; and Y Club, 3; contributions to (Argus) 78, (Press, Christchurch) 153, (Repertorian) 88, (Socialist) 73, 77, 87, 88, 229, (Tomorrow) 153, (Trident) 77; education, 74-5, 227-8; intellectual influences, 7, 77, 87-8; parents, 74; post-war disillusion, 153-4

slums, 24-5, 83

Social Democratic Federation, 62

Social Democratic Vanguard, 39

Social Questions Committee, 71

socialism, 2-3, 5, 15, 24, 26, 38-9, 40-2, 43, 45-6, 48, 51-3, 63, 71, $72-3,75-6,77,85,86,88,89-90,92-4,97,100,102,109,121,127$, $131,160,205,211$

Socialist, 17, 24, 25, 28-9, 39, 52, 71, 73, 77, 84, 86, 87, 88, 93, 102, 113, $129,132,133$

Socialist League, 62

Social Reform Bureau, 82

Social Science Club, 76

Spanish Civil War, 156, 161-3, 188

Spanish Relief Committee, 161, 162, 164

Spencer, Walter Baldwin, 95

Star, the, 159

Stead, Christina, 160, 177

Steele Rudd's Magazine, 33, 34, 36, 37, 56

Stephens, A. G., 16, 17, 28, 35

Stephensen, P. R., 211, 241

strikes, see industrial disputes

Strong, Archibald, 2

Strong, Rev. Charles, 87

suburbia, 8, 24, 29, 99, 121-2, 148-53 passim, 161, 164, 176, 196-7, 201, 207

Sunday Chronicle, 53

Sydney Bookstall Company, 213

Sydney Morning Herald, 127-8, 143-4

Synge, J. M., 12, 17, 18, 33, 64, 210

Table Talk, 17

Tate, Henry, 127

Taylor Card System, 103, 104, 130

Tennant, Kylie, 177

The Australian Poetry Annual, 116, 127

The Battler, 136-7

The Big Fellow, 190, 191, 217

The Black Horse and Other Plays, 2, 170

The Boss of Killara, 170, 214

The Bride of Gospel Place, 137

The Dilemma of an Australian Sociology, 205 


\section{Index}

The Georgian Revolt 1910-1922, 68

The Legend of the Nineties, 9, 190, 191-3

The Maid of the Mountains, 139

The Man Hamilton, 170-2, 175, 190, 216

The Passage, 59, 178-82, 184, 190, 191, 198, 216, 217

The Place of the Social Sciences in a Modern University, 96-7

The Rainbow Bird, 168, 217

The Shanty Keeper's Daughter, 170, 213

The Southern Cross, 79, 80, 81

The Swayne Family, 178, 182-8, 189, 217

The Time is Not Yet Ripe, 25-8, 30, 81, 134, 222

The Voice of the People, 137

The Waddy, 17

The World of Men, 54-5, 56, 174

Three Short Plays, 27, 28

Till the Day I Die, 163

Titterton, W. R., 48-9, 57

Tocsin, 63, 71

Tolstoy, Leo, 34, 39, 130

Town Life in Australia, 3

Triad, 116

Trident, 77

Tucker, T. G., 95,

Tomholt, Sydney, 135

Turner, Ethel, 148

Turner, Ian, 206

Twopeny, R. E. N., 3, 219

United Australia Party, 160

United Front, 159

Universal Service League, 97, 231

universities, 95, 96-7, 98, 106, 107-11, 114, 118, 159, 198, 204

Vanbrugh, Irene, 141-2

Victorian Labour College, 112, 232

Victorian Socialist Party, 2, 39, 41, 71-4, 75-6, 85, 86, 88, 129, 153, 227

Ward, Maisie, 48

Ward, Russel, 206, 208, 209

war novels, 157-8, 237

War Precautions Act, 156, 164, 195

Watson, J. C., 72

W.E.A., 153, 236

Wells, H. G., 6, 32, 38, 48, 164, 210

White, Lieutenant-Colonel T. W., 158

Whitman, Walt, 34

Wilde, Oscar, 15, 25, 210

Williamson, J. C. 141

Wilmot, Frank: and censorship, 159; and conscription, 98, 108, 117; and 


\section{Index}

his generation, 1; and Macartney, 85, 216, 226; and Melbourne, 2, 4, 55; and Melbourne Literary Club, 2, 127; and O'Dowd, 63, 67; and Palmer, 2, 216; and Pioneer Players, 137; and poetry, 8, 61-70 passim, $114-18,126,150,154,226,243$; and socialism, 2, 62-3, 71, 89, 129; and the city, 64, 66, 67, 150; and World War I, 70, 90, 114-18, 125-6; contributions to (Birth) 116, (Booklover) 114, (Felloweship) 73, 114, 117, 125, (Microbe) 63-4, (Tocsin) 63

Wilmot, Henry, 62

women: and film censorship, 145; femininity, 5, 56, 173-7; in Palmer's fiction, 168-72, 174-5, 177, 187-8; suffragettes, 51, 174-5

Worker, 103-5

worker control, see industrial democracy

working class, $1,14-15,23-4,29,41-2,44-5,51-3,54,93,101,104,112$, 194

World War I, 8, 10, 88, 90-3, 97-102, 104-18, 122-7, 133, 153, 155, 156, 194-6

World War II, 9, 153, 165

wowsers, 3-4, 8, 86, 146, 156, 158, 183; see also Judkins; Fitchett

Yarwood, A.T., 159

Y Club, 3, 219

Yeats, W. B., 17, 33, 37, 64, 135, 137, 210 
Dr David Walker is a graduate in history from Adelaide University and The Australian National University. $\mathrm{He}$ is a former editor of Labour History and now lecturer in the History Department at

Auckland University, New Zealand.
Australian National University Press ISBN 0708108253
Jacket designed by

ANU Graphic Design/Adrian Young

Printed in Hong Kong

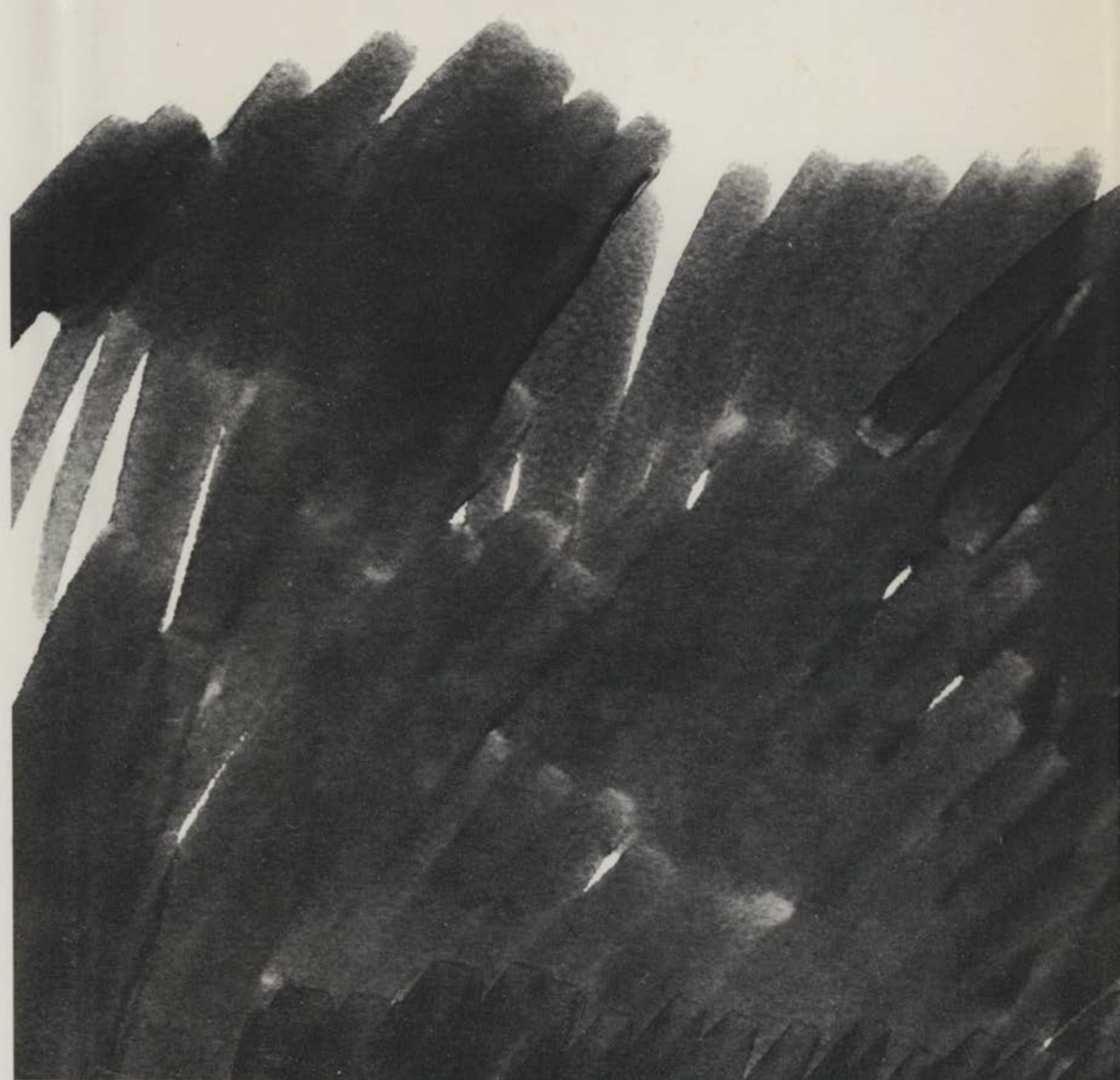

